\title{
Público e privado na política de assistência à saúde no Brasil atores, processos e trajetórias
}

\author{
Telma Maria Gonçalves Menicucci
}

\section{SciELO Books / SciELO Livros / SciELO Libros}

MENICUCCI, TMG. Público e privado na política de assistência à saúde no Brasil: atores, processos e trajetória [online]. Rio de Janeiro: Editora FIOCRUZ, 2007. 320 p. ISBN 978-85-7541-356-2.

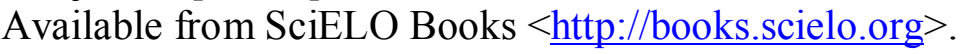

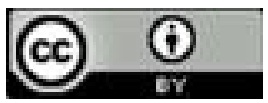

All the contents of this work, except where otherwise noted, is licensed under a Creative Commons Attribution 4.0 International license.

Todo o conteúdo deste trabalho, exceto quando houver ressalva, é publicado sob a licença Creative Commons Atribição 4.0. 


\section{Público e Privado na Política de Assistência à Saúde no Brasil atores, processos e trajetória}


FUNDAÇÃO OSWALDO CRUZ

Presidente

Paulo Ernani Gadelha Vieira

Vice-Presidente de Ensino,

Informação e Comunicação

Nisia Trindade Lima

\section{EDITORA FIOCRUZ}

Diretora

Nisia Trindade Lima

Editor Executivo

João Carlos Canossa Mendes

Editores Científicos

Gilberto Hochman

Ricardo Ventura Santos

Conselho Editorial

Ana Lúcia Teles Rabello

Armando de Oliveira Schubach

Carlos E. A. Coimbra Jr.

Gerson Oliveira Penna

Joseli Lannes Vieira

Lígia Vieira da Silva

Maria Cecília de Souza Minayo 


\section{Público e Privado na Política de Assistência à Saúde no Brasil atores, processos e trajetória}

Telma Maria Gonçalves Menicucci

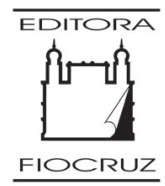


Copyright (C) 2007 da autora

Todos os direitos desta edição reservados à

FUNDAÇÃO OSWALDO CRUZ / EDITORA

ISBN: 978-85-7541-138-4

$1^{a}$ edição: 2007

$1^{\text {a }}$ reimpressão: 2011

Capa, projeto gráfico e editoração eletrônica

Carlota Rios

Copidesque e revisões

Jorge Moutinho

Supervisão Editorial

Janaina de Souza Silva

Catalogação-na-fonte

Centro de Informação Científica e Tecnológica

Biblioteca da Escola Nacional de Saúde Pública Sergio Arouca

M545p Menicucci, Telma Maria Gonçalves

Público e privado na política de assistência à saúde no Brasil: atores, processos e trajetória. / Telma Maria Gonçalves Menicucci. - Rio de Janeiro : Editora FIOĆRUZ, 2007.

320 p., tab., graf.

1.Assistência à Saúde-Brasil. 2.Setor Público. 3.Setor Privado. 4.Reforma dos Serviços de Saúdehistória. 5.Política de Saúde-história. 6.Saúde Suplementar. 7.Sistema Único de Saúde. 8.Regulamentação Governamental. I.Título.

CDD - 22.ed. - 362.104250981

2011

EDITORA FIOCRUZ

Av. Brasil, 4036 - térreo - sala 112 - Manguinhos

21040-361 - Rio de Janeiro - RJ

Tels: (21) 3882-9039 / 3882-9041

Telefax: (21) 3882-9006

e-mail: editora@fiocruz.br

www.fiocruz.br 
Para meus filhos, Paulinho, Juliana e Cacá, o sentido mais profundo em qualquer conjuntura e sob quaisquer condições; para minha irmã Tânia, meu porto seguro depois de tantas perdas 

Se nós estamos querendo atingir objetivos como universalização, equanimidade, integralidade do sistema, participação, é impossivel que um setor importante da assistência à saúde fique sujeito às leis do mercado. (Deputado constituinte Eduardo Jorge, Diário do Congresso Nacional, 17/7/1987) 



\section{Sumário}

$\begin{array}{ll}\text { Prefácio } & 11\end{array}$

$\begin{array}{ll}\text { Apresentação } & 15\end{array}$

1 Os Argumentos Analíticos:

a perspectiva histórica e institucional 21

2 A Constituição do Mix Privado/Público

na Assistência à Saúde $\quad 57$

3 As Formas Privadas de Assistência à Saúde:

desenvolvimento e características 103

4 A Reforma da Política de Saúde:

inovação e continuidade-1975/2000 163

5 A Regulação da Assistência à Saúde Suplementar 233

$\begin{array}{ll}\text { Conclusões } & 291\end{array}$

$\begin{array}{ll}\text { Referências } & 303\end{array}$ 


\section{Prefácio}

A menção honrosa à tese de doutorado em ciências sociais conferida pela Associação Nacional de Pós-Graduação e Pesquisa em Ciências Sociais (Anpocs) ao trabalho de Telma Maria Gonçalves Menicucci atesta, ainda que não explicite, a qualidade do material ali apresentado. Não fosse isso, seria quase supérfluo elaborar um prefácio para este texto que se constitui na melhor e mais completa avaliação das políticas de saúde no Brasil. Tendo orientado teses - e participado de bancas - focalizando a temática sob diferentes ângulos, sinto-me confortável - além de bastante honrado e gratificado - em fazer tal afirmação sobre um trabalho que foi desenvolvido sob a minha orientação no programa de doutorado em ciências humanas da Universidade Federal de Minas Gerais (UFMG), mas que é fruto do profundo conhecimento que a autora tem como pesquisadora na área. As razões são de fácil enunciado: trata-se de uma análise que, por um lado, retraça a trajetória da política de saúde no país, fornecendo um conhecimento abrangente e histórico para se entender as suas características no contexto que emerge das reformas neoliberais e culmina com os intentos de regulação; por outro, está baseada em um enorme e minucioso trabalho de pesquisa empírica que envolve tanto as dimensões diacrônicas quanto as sincrônicas do panorama da assistência à saúde.

Centrada em uma abordagem que privilegia um olhar histórico sobre a importância de instituições no âmbito da produção de políticas públicas, a análise se delimita no período que vai dos anos 60 até finais dos anos 90, marcado por diferentes características, seja do ponto de vista do modelo econômico subjacente, seja do ponto de vista do regime político e dos atores que são os produtores e consumidores da política de saúde que, finalmente, se 
instaura no quadro da regulação promovida pelas reformas de mercado em finais do século passado. O que se configura como a política de saúde nessa conjuntura é um sistema que pode ser caracterizado como dual, com forte dependência de trajetória, continuidades e também rupturas. Os anos $60 \mathrm{~mol}-$ dam o campo da saúde na medida em que ali se criam os atores, as bases da política, se definem os parâmetros dentro dos quais o processo vai se desenrolar e se tomam decisões com conseqüências estruturais de longo prazo. É a partir desse momento que começa a se expandir uma rede prestadora de serviços que fornece incentivos e fortalece os atores privados, gerando assim fortes continuidades em termos das características da política no período posterior. A ruptura se expressa a partir da conjuntura de redemocratização, como um campo favorável à institucionalização da proposta de criação do Sistema Único de Saúde (SUS), que se sobrepõe à tendência de privatização em curso. O desfecho é dado pela criação de um modelo de regulação que acaba por consolidar um sistema dual das políticas de saúde.

Relevante nessa visão processual da política é o esclarecimento de alguns pontos que freqüentemente rondam a discussão sobre a temática. O primeiro diz respeito à visão do modelo de política de saúde como associado comumente ao contexto das reformas de mercado que se implantam a partir de fins dos anos 80 e início dos 90. A análise mostra claramente que as tendências à privatização datam do período anterior, sugerindo cautela quanto a se atribuir às reformas recentes tanto a faceta privada do modelo como possíveis conseqüências numa direção mais homogênea. O segundo se refere à possível convergência de resultados em diferentes contextos em que tais reformas foram aplicadas. Novamente, a análise, embora não envolva comparações sistemáticas, sugere que a trajetória brasileira guarda especificidades que contrastam com as de outros países, como o Chile, onde o modelo de privatização se pautou pelos preceitos neoliberais com resultados bastante distintos.

Ainda um terceiro aspecto elucidado no trabalho diz respeito à segmentação estrutural que se verifica no modelo de política de assistência à saúde no Brasil em termos de classe social e, também, a um ponderado entendimento acerca da sua faceta pública. A pretensão de implantação de um modelo de acesso universal e financiamento público que emerge da Constituição de 1988 não modifica o quadro de acesso diferenciado e cobertura priva- 
da que vinha se configurando ao longo do tempo. Trata-se de uma dupla dualidade nesse sentido, não apenas em termos da cobertura público/privado, como também em termos da clientela atendida: os setores menos favorecidos de um lado, aglutinados na assistência pública, e os mais privilegiados, no âmbito privado. Aqui, porém, emerge uma dimensão interessante e de suma importância da análise empreendida pela autora, que tem a ver com uma valorização da cobertura e do acesso público, freqüentemente tratados de forma negativa no debate. Curiosamente, nesse particular, pesquisa realizada por ela sugere uma percepção mais positiva da prestação dos serviços públicos de assistência por parte dos seus usuários, a despeito da precariedade que comumente se associa ao SUS em uma avaliação difundida por não-usuários e pela mídia em geral.

É assim que o estudo esclarece o campo da política de saúde, a um tempo, em termos das formas de acesso e das formas de financiamento dos serviços, de maneira clara e bem fundamentada, limpando o terreno para uma avaliação objetiva e rigorosa. Sintetizando, nos termos da própria autora, "a proposição que considero melhor dar conta da experiência brasileira é que, com a criação do Sistema Único de Saúde, houve de fato uma inovação institucional significativa do ponto de vista interno da assistência prestada pelo setor público diretamente. Entretanto, do ponto de vista do conjunto da assistência, essa mudança setorial não significou uma mudança de rota na assistência à saúde considerada em sua totalidade".

O texto de Telma Menicucci pode ser considerado um marco no âmbito das análises de políticas públicas em geral, em vista da profícua perspectiva aqui adotada de considerar atores, processos e contexto para o entendimento da mudança institucional de longo prazo, na qual legado e inovação se combinam de formas complexas, muitas vezes não passíveis de serem desvendadas por modelos estáticos ou análises sincrônicas. Ao mesmo tempo, o grande mérito da análise reside em que a autora alia a tal abordagem o conhecimento empírico necessário à compreensão dessa dinâmica em um campo específico, o que qualifica o trabalho como um divisor de águas também na análise das políticas de saúde em particular.

Renato R. Boschi

Professor titular do Instituto Universitário de Pesquisas do Rio de Janeiro/Universidade Candido Mendes (Iuperj/Ucam) 



\section{Apresentação}

A década de 80 no Brasil é caracterizada pelo processo de democratização do país, que se traduziu na promulgação de uma nova Constituição, em 1988. No campo da saúde, a nova Carta trouxe importantes inovações ao consagrar o direito à saúde e ao definir princípios e diretrizes para orientar a política setorial, os quais, formalmente, alteraram significativamente o padrão anterior, particularmente ao garantir o acesso universal, igualitário e gratuito às ações e aos serviços de saúde. Ao romper com o caráter meritocrático da assistência à saúde, originariamente no Brasil vinculada à inserção no mercado de trabalho, e ao incorporá-la à idéia de cidadania, a política de saúde definida na Constituição pode ser considerada, de fato, como uma ruptura com os princípios que deram sustentação às políticas que tinham caracterizado a trajetória brasileira até então. E mesmo que a criação do Sistema Único de Saúde (SUS), que traduziu institucionalmente a reformulação do setor, tenha significado a consolidação de um processo gradativo de expansão da cobertura pública, a ampliação de seu escopo com a universalização formal é bastante significativa em termos de um reordenamento ideológico e institucional.

Entretanto, a criação desse sistema nacional de saúde inclusivo não logrou incorporar todos os cidadãos à assistência pública, uma vez que um expressivo contingente deles já vinha sendo absorvido por formas privadas de assistência à saúde, em um processo que foi mais intenso exatamente durante a formação e redefinição da política de saúde nos anos que antecederam a promulgação da Constituição. A própria atuação governamental, expressa em decisões e políticas do período pós-constitucional, iria expressar essa dualidade, uma vez que ainda no início da década de 90, concomitantemente aos esfor- 
ços de viabilização da política recém-definida na Constituição, foi introduzido na agenda pública o tema da regulamentação governamental dos planos privados de saúde, que se concretizaria no final da década. O debate no Congresso Nacional e na sociedade em geral em torno da regulamentação e do controle governamental da assistência privada contribuiu para tornar transparente a relevância que ela já tinha assumido no Brasil como alternativa ao sistema público.

Aparentemente, esses dois processos - a implantação do sistema de saúde público e universal e o estabelecimento de uma política regulatória da assistência privada - ocorreram de forma independente, envolvendo, em grande parte, atores privados e agências governamentais distintas. Isso significa que essa regulação não se deu no sentido de definir a inserção de mecanismos de mercado na estrutura da assistência de responsabilidade estatal e de caráter universal, mas de consolidar o funcionamento do sistema privado de forma independente do sistema público. Uma vez que a regulação do setor privado não ocorreu no sentido de definir sua articulação com o setor público ou de determinar espaços e regras de atuação, o resultado da política de saúde no final da década - e apenas dez anos após as mudanças constitucionais - tornou evidente a existência de duas formas radicalmente distintas, não apenas de acesso, financiamento e produção das ações e dos serviços de saúde, mas também de atuação governamental. Por um lado, a atuação estatal se dá no sentido de garantir o acesso universal às ações e aos serviços de saúde como elemento que integra a noção de direito à saúde. Por outro lado, a política de saúde passa, formalmente, a incorporar a assistência privada ao escopo da intervenção governamental na forma de regulação do mercado privado de assistência, com vistas a desenvolver esse mercado, garantindo os direitos do consumidor. Ao fazer isso, a própria política consagra e legitima o caráter dual da assistência. Nessa perspectiva, a ação governamental orienta-se por duas lógicas distintas: a lógica da assistência como um direito de cidadania, que traz implícitas as idéias de universalidade e igualdade; e a lógica da assistência como um bem oferecido e adquirido em um mercado que, por sua vez, remete à diferenciação por segmentos e produtos, definida com base no poder de compra ou em condições privilegiadas de acesso ao consumo de serviços de saúde.

Este livro, que é uma versão revista de minha tese de doutorado em ciências humanas - sociologia e política - defendida na Faculdade de Filosofia 
e Ciências Humanas da Universidade Federal de Minas Gerais (UFMG) em 2003, tem como objetivo explicar a constituição do formato institucional híbrido ou dual da assistência à saúde no Brasil, entendendo-se como tal a coexistência de um sistema público e de um sistema privado, que configuram formas diferenciadas de acesso, financiamento e produção de serviços, apesar de, formalmente, a política de saúde definir o acesso gratuito e universal a toda a população sem distinções. O principal argumento de que se parte para explicar esse aparente paradoxo considera que, embora esse arranjo institucional consolidado na política de assistência à saúde seja resultado de escolhas entre diferentes alternativas disponíveis, essas escolhas, realizadas em diferentes momentos de inflexão da política de saúde, foram constrangidas pelos efeitos institucionais das escolhas anteriores. E o que é mais decisivo é que a própria conformação da arena política da saúde onde se dá o conflito entre alternativas decorre de políticas anteriores, particularmente as que foram definidas a partir dos anos 60, as quais contribuíram para a constituição de diferentes atores e interesses, a partir dos incentivos oferecidos e dos benefícios concedidos aos afetados pelas políticas. Isso significa que o estabelecimento de determinadas políticas de saúde na década de 60 propiciou a constituição de identidades e clivagens sociais que se expressam em distintas compreensões e preferências quanto às alternativas de políticas.

Esse argumento compartilha a premissa básica da abordagem denominada de novo institucionalismo, incorporada a diferentes perspectivas teóricas, e enfatiza a importância das instituições no comportamento e nos resultados políticos para a explicação da política de saúde. Com base nesse pressuposto, o trabalho busca identificar como a existência de arranjos estáveis e rotinizados estruturam o comportamento político e, nessa medida, estabelecem os contornos dentro dos quais as decisões são tomadas. A incorporação da análise histórica ao estudo da política de saúde permite iluminar o fato de que os decisores, em cada momento histórico, operaram em um ambiente condicionado por políticas do passado que não apenas institucionalizaram práticas e regras, mas também constituíram diferentes atores.

Partindo da idéia de que os fenômenos sociais são path dependent - isto é, o que acontece em um ponto no tempo afetará os resultados de uma seqüência de eventos posteriores -, o padrão institucional de assistência à saúde vigente 
hoje no Brasil é dependente das políticas ou escolhas anteriores, particularmente a partir da década de 60 , de tal forma que as diferentes opções ocorridas nas últimas três décadas não são independentes umas das outras, estando, ao contrário, conectadas. Entender as decisões como limitadas pelas escolhas do passado remete a uma explicação que - sem negar os constrangimentos econômicos e políticos, nacionais e internacionais, que caracterizam a conjuntura de implantação do SUS, marcada por crise econômica, políticas de ajuste e mudanças na configuração do Estado - enfatiza os mecanismos institucionais estabelecidos com base em desenhos de políticas estabelecidas previamente.

Essa interpretação contraria as explicações que identificam certa convergência no desenvolvimento recente das políticas sociais no sentido de privatização, no contexto de reforma do Estado e de políticas de ajuste que coincidiram com o processo de implantação da reforma da política de saúde nos anos 90. No caso brasileiro, o timing do processo de fortalecimento do setor privado não acompanha o movimento de reforma de Estado e de revalorização do mercado, não podendo ser visto como simples resposta às mudanças recentes nas concepções sobre a relação Estado/mercado na provisão e gestão de serviços de saúde. O contexto econômico, político e ideológico de reforma tende, contudo, a legitimar e aprofundar a trajetória da política de saúde brasileira, enfraquecendo a proposta universalizante definida na conjuntura de democratização e cuja concretização vai coincidir com a crise do Estado e com o movimento de inflexão em direção ao mercado, o qual, no Brasil, já ocorrera previamente.

Gostaria de agradecer às pessoas e instituições que me apoiaram na realização da tese e na publicação deste livro. Em primeiro lugar, agradeço aos meus orientadores, Renato Boschi, no doutorado, que de maneira muito respeitosa e sem imposições favoreceu a construção analítica da tese, desde suas aulas e durante a orientação, além de ter sido e continuar sendo um grande incentivador. E Mercês Somarriba, minha orientadora ainda no mestrado, mas que não deixou de ser uma referência intelectual ao longo de minha trajetória, particularmente quanto ao rigor e interesse temático.

O apoio institucional da Escola de Governo da Fundação João Pinheiro, por intermédio de seus diretores, Ricardo Carneiro e Laura da Veiga, e ainda de meus colegas de trabalho - todo o grupo da Superintendência de 
Pesquisa, grandes amigos e amigas, além de companheiros e companheiras de trabalho, alegrias e aflições -, foi fundamental para a realização da tese. À Associação Nacional de Pós-Graduação e Pesquisa em Ciências Sociais (Anpocs), agradeço o reconhecimento do meu trabalho, que foi um incentivo à sua publicação.

Particularmente, agradeço a Gilberto Hochman pelo seu estímulo sempre tão delicado para a publicação deste livro, apostando nele e, de algum modo, me ajudando a superar certo imobilismo. Por sua sensibilidade e incentivo, meu muito obrigada. 



\section{Os Argumentos Analíticos: a perspectiva histórica e institucional}

O argumento básico, que norteou a interpretação da política de assistência à saúde no Brasil, foi construído com base nos argumentos gerais e pressupostos da abordagem neo-institucionalista. ${ }^{1} \mathrm{O}$ ponto de partida é o modelo analítico utilizado por Pierson $(1993,1994)$ para o estudo de políticas públicas, que incorpora contribuições da vertente histórica do novo institucionalismo, desenvolvida particularmente no campo da política comparada e aplicada a estudos de diferentes processos políticos. Apesar de suas diferenciações, os trabalhos identificados com o institucionalismo histórico partilham de um pro-

\footnotetext{
O novo institucionalismo não se constituiu como uma nova teoria, mas um conjunto de argumentos que freqüentemente se associa a teorias diferenciadas. Nas suas diferentes manifestações, a explicação considera que a forma de organização da vida política tem influência sobre a política, o que significa atribuir um papel mais autônomo para as instituições políticas, as quais deixam de ser vistas apenas como arenas, e passam a ser vistas também como atores políticos, ao configurarem um conjunto de estruturas e procedimentos que definem e defendem interesses. Pode-se dizer que essa abordagem busca responder de forma diferente à pergunta sobre como as escolhas sociais são modeladas, mediadas e conduzidas por arranjos institucionais (Powell \& DiMaggio, 1991), entendendo que as preferências e os significados não são estáveis nem exógenos, mas podem ser moldados pelas experiências políticas ou por instituições políticas relativamente autônomas. Uma conseqüência desse argumento é que o sistema político deixa de ser visto como estritamente dependente da sociedade. Da mesma forma, a distribuição de recursos políticos pode ser afetada pelas instituições políticas, no contexto das quais são também desenvolvidas as regras do jogo (March \& Olsen, 1984, 1989). Nessa perspectiva, o Estado, como instituição política fundamental, não é apenas afetado pela sociedade, mas também a afeta, de tal forma que estudos que trazem 'de volta' o Estado fazem parte da perspectiva neo-institucionalista (Evans, Rueschemeyer \& Skocpol, 1985). Na teoria social, o novo institucionalismo implica a necessidade de combinar tanto a agência quanto a estrutura em qualquer explicação do comportamento e dos resultados sociais, rompendo com modelos explicativos polarizados ao reconhecer que as preferências dos indivíduos vêm de estruturas e experiências passadas, mas que, ao mesmo tempo, é preciso ter agentes que sejam portadores dos imperativos estruturais e que no processo de reproduzir as estruturas sejam capazes também de remodelá-las (Goodin, 1996).
} 
jeto teórico 'de médio alcance', que considera a contingência histórica e a dependência de trajetória (Thelen \& Steinmo, 1994; Pierson, 1993, 1994; North, 1990; Weir, 1994), e procuram explicar as diferenças entre os resultados políticos entre países levando em consideração variáveis institucionais, buscando identificar como as lutas políticas são mediadas pelo arcabouço institucional dentro do qual elas acontecem (Thelen \& Steinmo, 1994; Hall \& Taylor, 1996). Em contextos nacionais diferentes, a influência de estruturas socioeconômicas e políticas para moldar o comportamento é percebida de maneiras distintas, e a diversidade de respostas a desafios e pressões comuns leva à identificação de fatores explicativos específicos de cada país, entre eles os fatores institucionais de nível nacional. Para explicar as diferenças entre países, o novo institucionalismo focaliza as instituições domésticas, enfatizando o seu caráter relacional mais do que as características formais das instituições. Isso significa verificar empiricamente como uma configuração institucional modela as interações e as estratégias políticas e estrutura as relações de poder entre grupos, conseqüentemente, influenciando os resultados (Immergutt, 1992; Hattam, 1993). Essa opção analítica conduz a um foco nos processos políticos e de elaboração de políticas públicas, entendidos como fluindo dentro de determinados parâmetros institucionais. Para muitos representantes dessa vertente, $\mathrm{o}$ Estado passou a ser considerado não como um agente neutro entre interesses em competição, mas como um complexo de instituições capazes de estruturar o caráter e os resultados do conflito entre grupos (Rueschmeyer, Trintberger, Stepan, Katzenstein e Tilly, entre outros, apud Skocpol, 1985). Outras instituições sociais e políticas também podem estruturar as interações entre interesses organizados, legisladores e judiciário. Em conseqüência, são geradas trajetórias nacionais diferentes. ${ }^{2}$

$\mathrm{Na}$ construção do argumento aqui defendido, parte-se do modelo de Pierson e incorporam-se outras hipóteses e pressupostos utilizados no escopo

\footnotetext{
Ao considerar que as instituições estruturam as lutas políticas e nessa medida influenciam os seus resultados, o novo institucionalismo não nega a influência de forças políticas mais amplas, mas tenta integrar a análise institucional com a contribuição de outros fatores sobre os resultados políticos, entre eles o desenvolvimento socioeconômico e a difusão das idéias, chamando a atenção, particularmente, para a relação entre instituições e idéias ou crenças. O enriquecimento do modelo explicativo, em decorrência da incorporação de um leque maior de variáveis à estrutura analítica, pode ter como contrapartida a imprecisão teórica, em razão da dificuldade de explicitar o peso explicativo de cada um dos fatores que compõem os modelos analíticos.
} 
da abordagem institucional transpostos para a análise da política de saúde. Os conceitos básicos dos quais se partiu para a construção do argumento são o de dependência de trajetória e de efeitos de feedback das políticas prévias sobre o processo político e, conseqüentemente, sobre as escolhas de políticas. Ao contribuir para a formação dos objetivos e preferências dos atores, além de configurar uma estrutura institucional em decorrência de sua implantação, as políticas, uma vez estabelecidas, limitam as possibilidades de reformas, aprisionando, de certa forma, comportamentos e conformando determinadas trajetórias. Nessa perspectiva, as reformas de políticas são explicadas pela confluência de fatores externos à própria política, como mudanças no contexto político mais amplo, mas tendendo sempre a inovações limitadas. No caso da política de saúde, a reforma que levou à criação de um sistema público universal foi possível em um contexto de democratização, que permitiu a constituição de novos atores, portadores de propostas alternativas para a saúde, e em uma situação de desequilíbrios institucionais, favorável a mudanças. Entretanto, a mudança institucional advinda com a criação do SUS carregará no seu bojo características do modelo institucional anterior.

Nas seções seguintes, esse modelo analítico é desenvolvido e sintetizado nas proposições que conduziram o estudo. Na última seção, são descritas a estratégia de análise, as fontes utilizadas e a estrutura do texto, especificando como em cada capítulo o argumento analítico foi utilizado na interpretação dos elementos empíricos de forma a construir uma explicação plausível da política de saúde vigente no Brasil, a qual se expressa em um arranjo institucional dual.

\section{Instituições e Políticas Públicas - a dependência de trajetória e os efeitos de feedback: sua influência no processo político}

Como ponto de partida, é necessário precisar a concepção de instituição, na medida em que a análise da reforma da política de saúde é feita levando-se em consideração fatores institucionais. No âmbito do novo institucionalismo, é possível encontrar diferentes definições, uma vez que a utilização desse enfoque ainda não se traduziu na constituição de um conjunto de conceitos teóricos 
precisos. ${ }^{3}$ Em conseqüência, o termo 'instituição' assume significados diversos em contextos analíticos distintos, com base em uma concepção genérica de instituição como um padrão de comportamento estável, recorrente e valorizado.

Na definição de Jepperson (1991), instituições são sistemas de regras socialmente construídas e reproduzidas rotineiramente que operam como ambientes limitadores e são acompanhadas de eventos tidos como dados. Nessa perspectiva sociológica, a teoria organizacional define instituições como regras, procedimentos e normas, e inclui também um sistema de símbolos, scripts cognitivos e modelos morais que fornecem a estrutura de significação que guia a ação, quase que identificando instituições com cultura (Powell \& Dimaggio, 1991). No âmbito do novo institucionalismo econômico, instituições podem também ser entendidas como costumes e regras em uma sociedade que funcionam como constrangimentos delineados para modelar a interação entre os homens e provêem um conjunto de incentivos e de desincentivos para os indivíduos (North, 1990); ou são regularidades em interações repetidas ou arranjos sociais gerados para minimizar os custos de transação (custos de negociação, execução e coação) e a incerteza, ao prover marcos de referência eficientes para a troca econômica (Williamson, 1985). No âmbito da ciência política e da abordagem da escolha racional, instituições são entendidas como estruturas de regras, procedimentos e arranjos (Shepsle, 1986); ou, ainda, inclinações congeladas temporariamente (Riker, 1980) ou prescrições sobre que ações são exigidas, proibidas ou permitidas em determinado contexto (Ostrom, 1986). Nos estudos voltados para as instituições internacionais que promovem a cooperação internacional (Krasner, Keohane, Young, apud Skocpol, 1985), instituições são entendidas como práticas constituídas de papéis facilmente identificáveis, unidos com conjuntos de regras ou convenções que governam as relações entre os ocupantes desses papéis. Na perspectiva do institucionalismo

Como alertam Powell e DiMaggio (1991), é mais fácil existir acordo sobre o que o novo institucionalismo não é do que sobre o que ele é. Pode-se falar de vários novos institucionalismos que assumem significados diferentes nas diversas disciplinas que se utilizam desse referencial teórico - como a economia, a ciência política, a história, a sociologia e, associada a esta, a teoria organizacional -, bem como nas intradisciplinas. Isso porque em cada campo disciplinar é possível identificar diferentes novos institucionalismos que se distinguem pelos pressupostos teóricos mais gerais que orientam os estudos. Além disso, vários pressupostos perpassam os campos disciplinares, tornando imprecisas as distinções, o que se verifica particularmente no campo da ciência política, com forte influência do novo institucionalismo econômico. Sobre uma comparação entre as diferentes vertentes, ver Hall e Taylor (1996), Goodin (1996), Powell e DiMaggio (1991). 
histórico (Hall \& Taylor, 1996; Thelen \& Steinmo, 1992; Skocpol, 1985), a definição de instituição inclui tanto organizações formais quanto regras e procedimentos informais que estruturam a conduta.

É na perspectiva mais ampla de instituições como regras do jogo ou como limites que estruturam a interação humana que o conceito de instituição é incorporado à análise de políticas públicas (Pierson, 1993, 1994), e é dessa forma que foi considerado no estudo da política de assistência à saúde. A maioria dos estudos de cunho institucionalista, que enfatizam os constrangimentos institucionais, usualmente buscam identificar as maneiras como as regras do jogo formais e informais na vida política e social influenciam o comportamento político e, de forma mais usual, centram-se nas instituições governamentais formais e nas organizações políticas. Entretanto, as principais políticas públicas também constituem importantes regras do jogo em uma sociedade, influenciando a alocação de recursos econômicos e políticos e modificando os custos e benefícios associados a estratégias políticas alternativas. Assim, é possível incluir as políticas públicas na definição mais ampla de instituição. E a pertinência de uma abordagem institucionalista para o estudo de políticas públicas pode ser vista de dois aspectos. Por um lado, as políticas públicas, em grande medida, costumam levar à constituição de instituições para viabilizar sua implementação, entendendo-se instituições tanto como organizações formais quanto como regras que estruturam o comportamento; por outro, elas próprias podem ser vistas como tendo os mesmos efeitos de estruturas institucionais, na medida em que provocam constrangimentos ao comportamento dos atores políticos e às decisões que podem ser tomadas relativamente a bens públicos, ou seja, para a elaboração ou reforma de políticas públicas. Daí que o exame das conseqüências políticas das políticas públicas é uma extensão lógica dos argumentos do novo institucionalismo utilizados para a análise de instituições formais, e o feedback das políticas se constitui em fator de ordem institucional bastante potente para a compreensão das políticas públicas.

Essa influência das políticas públicas no processo de constituição ou de reformas de políticas se expressa pelas noções correlatas de policy feedback e da dependência de trajetória, traduzidas nos efeitos lock-in e nos efeitos de aprendizagem. Essas noções, utilizadas para análises institucionais voltadas para as 
instituições formais (Arthur, 1989, apud Pierson, 1993; Weir, 1994; North, 1990), são aqui incorporadas para o estudo das políticas públicas, as quais podem ser vistas como tendo os mesmos efeitos de instituições formais. Do ponto de vista teórico-metodológico, a proposição analítica básica do argumento aqui defendido é de que os legados das políticas de saúde previamente estabelecidas explicam, em grande parte, o seu desenvolvimento futuro, de tal forma que, em razão de seus efeitos institucionais, os desenhos de políticas preestabelecidas condicionaram o processo de reformulação das políticas durante o processo constituinte e, posteriormente, no momento de implantação da reforma. Esta proposição traz implícito o pressuposto de que as políticas públicas não se constituem apenas em variáveis dependentes - nesse caso, sendo o resultado da ação de forças políticas -, mas também funcionam como variáveis independentes, que podem ser uma das causas dessas forças. Como variáveis independentes, as políticas públicas também explicam o processo de formulação ou de reformas de políticas, na medida em que, por um lado, condicionam o próprio processo político e, por outro, explicam a trajetória futura de uma política a partir de sua constituição prévia.

Com base nesse pressuposto, a questão teórica mais geral para a qual é necessário dar uma resposta é a seguinte: como as políticas públicas influenciam os processos políticos e as políticas subseqüentes? Os desdobramentos analíticos da noção de dependência de trajetória fornecem os elementos para responder a essa questão, o que só pode ser feito pela análise que recupere os processos históricos de constituição e reforma das políticas, articulando o processo decisório com o contexto institucional das políticas vigentes.

As políticas públicas estabelecem 'regras do jogo', e estas influenciam a alocação de recursos econômicos e políticos e provêem recursos e incentivos para atores políticos, o que, além de facilitar a formação ou expansão de grupos particulares, encoraja determinadas ações e bloqueia outras, definindo assim um determinado caminho ou padrões de comportamento (efeitos lockin). Dessa forma, uma conseqüência do desenho de políticas já estabelecidas é a formação de grupos de interesse e, em decorrência, a organização e constituição de atividades desses grupos, podendo ainda, ao contrário, inibir a formação ou expansão de outros grupos. Ou seja, a repartição desigual de recursos e de informação como conseqüência de ações governamentais específicas 
cria incentivos à organização de determinados grupos favorecidos com as políticas, de tal forma que os desenhos de políticas públicas alteram os processos políticos e modelam identidades de grupo. Uma conseqüência disso é que esses mesmos interesses podem oferecer obstáculos a alterações institucionais posteriores e/ou a alterações de políticas. Em outros termos, as políticas definidas em um momento no tempo estruturam o processo de tomada de decisões e criam fortes coalizões de suporte que efetivamente protegem os arranjos institucionais estabelecidos, tendo efeitos de feedback no processo político.

É nessa perspectiva que as políticas de saúde definidas a partir dos anos 60 não apenas dificultaram determinadas escolhas posteriores, em razão dos arranjos e estruturas desenvolvidas para a concretização das políticas, mas também estruturaram interesses, o que teve conseqüências sobre o conflito político associado às disputas por alternativas de intervenções públicas no campo da assistência à saúde. Isso quer dizer que essas políticas anteriores alteraram o desenvolvimento político subseqüente, uma vez que constituíram grupos de interesse e geraram atividades para eles, configurando, em grande parte, seus objetivos políticos e suas preferências, em razão dos incentivos ou das vantagens distributivas estabelecidos pela política. Diversos incentivos fornecidos pelo modelo de assistência delineado pela política de saúde da década de 60 favoreceram, por exemplo, o desenvolvimento da assistência médica de caráter empresarial em detrimento da assistência pública, afetando, dessa forma, o desenvolvimento de diversos segmentos empresariais e propiciando o surgimento de instituições e organizações, como a medicina de grupo, as cooperativas médicas e os sistemas de autogestão vinculados a empresas empregadoras. Esses segmentos empresariais da assistência à saúde organizaram-se politicamente, vindo a constituir organizações de interesses e a concentrar recursos políticos que lhes permitiram obter significativa influência no processo decisório.

O formato institucional da política de assistência à saúde teve conseqüências na constituição dos interesses não apenas dos empresários da saúde, mas também dos atores beneficiados por ela. A forma como a política de assistência foi prioritariamente desenvolvida, cujo ramo principal se originou nas instituições previdenciárias, favoreceu, inicialmente, a inclusão corporativa dos trabalhadores inseridos no mercado de trabalho urbano como um benefício 
meritocrático. Em um segundo momento, correlatamente à ruptura formal do padrão corporativo de inclusão, a política de saúde teve como efeito o incentivo à cobertura, por formas privadas e privilegiadas de assistência, de segmentos dos trabalhadores concentrados nos setores produtivos mais dinâmicos. Mesmo com a unificação das instituições previdenciárias, que formalmente rompeu com a fragmentação, a expansão da assistência médica passou a se dar por outras formas de segmentação, diferenciando os trabalhadores conforme o tipo de assistência prestada e o prestador, mesmo que financiada pelo poder público, direta ou indiretamente.

Essa forma histórica de desenvolvimento da assistência não favoreceu a constituição de uma identidade coletiva entre o público-alvo da política capaz de articular uma demanda universalista. Ao contrário, propiciou a particularização das demandas de saúde e a constituição de identidades corporativas. ${ }^{4}$ Esse modelo vai ter conseqüências decisivas na implantação da reforma da política nos anos 90, que não vai contar com o apoio efetivo, embora o tenha formalmente, dos setores mais mobilizados dos trabalhadores. Estes, já incluídos em formas privadas de atenção à saúde, não apenas desenvolveram uma perspectiva corporativista na demanda por serviços de saúde, mas, na prática, apoiaram as formas privadas de provisão de serviços, vinculadas ao contrato de trabalho. Em suma, o formato da política de saúde, ao dificultar a identificação dos trabalhadores organizados com uma assistência pública e igualitária, traduziu-se na ausência de mobilização e suporte político efetivo a uma reforma publicista e universalista. Isso teve como efeitos, dentre outros, o enfraquecimento dessa proposta e o fortalecimento da segmentação de clientelas, reforçando a perspectiva de que ao Sistema Único de Saúde (SUS) cabe a cobertura da população mais pobre e em condições desfavoráveis de inserção no mercado de trabalho.

Por sua vez, fortes coalizões contrárias à reforma, formadas principalmente pelos empresários do setor saúde, foram capazes de alterar a proposta original de reforma da política de saúde no momento crucial de sua definição, de forma a garantir os seus interesses, forjados também na trajetória da polí-

Idéia similar é defendida por Fleury (2001), para quem o sistema de seguridade implantado não logrou difundir uma cultura cívica nem estender a condição de cidadão. 
tica de saúde, o que resultou no padrão limitado da reforma. Isso se deu principalmente a partir de seu poder de veto, na medida em que os empresários do setor foram capazes de influenciar não-decisões, limitando as decisões de forma a possibilitar a manutenção do status quo, apesar da reforma. ${ }^{5}$ Em momentos decisórios cruciais, como durante o processo constituinte e na regulação da assistência à saúde suplementar, esses interesses, já organizados desde as décadas anteriores, detinham recursos políticos suficientes para exercerem seu poder de pressão e de veto, tendo sido bem sucedidos na proteção dos arranjos institucionais previamente estabelecidos.

A operação e o desenvolvimento da política de assistência à saúde tiveram como um dos seus efeitos a geração de assimetrias de poder entre os grupos afetados por ela, modelando também diferentes identidades entre os atores beneficiados pelas políticas. Essa assimetria garantiu que, em diferentes momentos, alguns interesses tivessem maior acesso ao processo decisório, de forma a ter maior capacidade de influenciar os resultados. Desse modo, na análise da trajetória da política tratou-se de verificar como a configuração da política de saúde não apenas afetou o desenvolvimento de atores e a constituição de interesses, mas também modelou as interações e as estratégias políticas dos grupos beneficiados por ela, de tal forma que as transformações da política passam a fluir segundo os parâmetros determinados pelo próprio formato da política. É nessa medida que as políticas de saúde estruturaram o processo decisório.

\section{Outros Efeitos de Feedback de Políticas Prévias: efeitos lock-in e efeitos de aprendizagem}

O efeito lock-in significa a definição de padrões de comportamento que são difíceis de ser revertidos. Além de propiciar o surgimento e/ou o desenvolvimento de atores e interesses, ao criarem determinados incentivos, as políticas públicas encorajam a emergência de determinadas redes sociais e econô-

\footnotetext{
Bachrach e Baratz (1962) também consideraram o efeito lock-in, o qual pode conduzir a 'nãodecisões' como expressão de poder na sua face menos aparente em situações em que um ator procura reforçar valores e práticas institucionais, de forma a serem objeto de consideração pública apenas as questões que são inócuas para ele.
} 
micas, levando os indivíduos a fazerem compromissos, a desenvolverem habilidades específicas e a comercializarem determinados bens etc., em resposta a tipos de ação governamental (Pierson, 1993, 1994). Na análise das instituições, o efeito lock-in decorre da relação simbiótica entre instituições e organizações que se desenvolvem como conseqüência da estrutura de incentivos fornecida por aquelas instituições (North, 1990). Da mesma forma, as políticas públicas, ao induzirem os indivíduos a determinados comportamentos e ao propiciarem o surgimento de organizações influenciadas pela evolução das políticas e da estrutura institucional correspondente, ampliam os custos associados à adoção de alternativas diversas, e, nessa medida, inibem o abandono de certa trajetória, que se torna assim difícil de ser alterada, inviabilizando alternativas que anteriormente podiam ser possíveis.

Esse efeito de aprisionamento dos comportamentos e decisões pode ser observado nas políticas de saúde, na medida em que elas estabeleceram determinadas 'regras do jogo', ou mecanismos e formatos institucionais, para a prestação de assistência à saúde, e, ao fazerem isso, induziram determinados comportamentos e investimentos difíceis de reverter. Em primeiro lugar, a decisão governamental de ampliar a cobertura para os trabalhadores assalariados pela incorporação da assistência médica aos benefícios prestados pelas instituições previdenciárias - inicialmente, as Caixas e, depois, os Institutos de Aposentadoria e Pensões - foi acompanhada da opção pela compra de serviços de prestadores privados, em vez da constituição de uma rede prestadora pública capaz de atender a uma demanda crescente. Em segundo lugar, com o objetivo similar de aumentar a cobertura e aliviar a pressão sobre a rede públi$\mathrm{ca}$, foram concedidos incentivos às empresas para que se encarregassem da assistência de seus empregados, o que foi feito, na maioria das vezes, também pela compra de serviços de prestadores privados. Essas opções tiveram dois efeitos principais: criar um mercado cativo para os prestadores de serviços de saúde financiado com recursos públicos; e desenvolver a prática empresarial de assumir a responsabilidade pela assistência de seus empregados. Tal prática vai permanecer e se desenvolver mesmo quando extintos os incentivos governamentais. Dessa forma, a política de saúde influenciou diretamente a alocação de recursos econômicos para determinados grupos que foram incentivados a realizar investimentos, seja no sentido de desenvolverem sua capacidade de 
produzir serviços para captarem os recursos públicos pela venda de serviços de saúde, seja pela assunção da assistência à saúde de seus empregados.

A conseqüência foi a constituição de uma rede complexa formada por prestadores de serviços de saúde (profissionais de saúde e hospitais), empresas médicas (medicina de grupo, cooperativas), seguradoras do ramo saúde, empresas empregadoras com sistemas de saúde para seus empregados, usuários e burocracia pública. A configuração institucional decorrente do modelo da política de assistência à saúde modelou as interações entre os grupos afetados diretamente pela política, tanto os favorecidos economicamente quanto os beneficiados pela cobertura assistencial. A rede densa que se constituiu em torno da assistência médica em razão das decisões e da regulação governamental, que se traduziu em práticas ou formas diferenciadas de prestação de assistência à saúde, além de modelar atores, interesses e identidades, teve o efeito de dificultar o abandono de certa trajetória, tornando quase inacessíveis alternativas que alterassem radicalmente o padrão de comportamento vigente.

As opções anteriores, ao propiciarem o desenvolvimento de formas privadas de assistência, colocaram limites à mudança de trajetória, em razão também dos efeitos que tiveram na capacidade governamental. A opção pela compra de serviços não permitiu que fosse desenvolvida a capacidade prestadora do governo, na medida em que significou a não-decisão de ampliar a rede de serviços públicos. Pela própria natureza da política de saúde, que demanda a existência de uma rede ampla e diversificada de serviços, essa opção teve o efeito de tornar o setor público dependente dos serviços privados. $\mathrm{Na}$ medida em que os interesses dos prestadores se faziam valer no espaço burocrático, capturado pelos interesses privados mediante potentes anéis burocráticos, o governo não conseguiu desenvolver sua capacidade reguladora, o que reforçou os efeitos de feedback do modelo da política e fez com que a lógica da atuação pública fosse submetida à lógica dos interesses privados.

No modelo de Pierson, as políticas públicas têm ainda importantes efeitos cognitivos, como uma outra face do efeito de feedback. De um lado, porque fornecem informações e atribuem significados à realidade; de outro, porque afetam o processo de aprendizagem social entre os principais atores políticos. Esses efeitos de aprendizagem podem ser positivos ou negativos, tanto 
do ponto de vista do Estado quanto da perspectiva dos atores sociais. No caso do Estado, os desenhos das políticas podem favorecer ou não o desenvolvimento de capacidades estatais; e, no âmbito da sociedade, podem gerar reações positivas ou negativas a determinados padrões de políticas públicas. $\mathrm{O}$ estabelecimento de determinados cursos de ação induzidos de políticas públicas pode influenciar a consciência individual sobre a atividade do governo. A elaboração de uma nova agenda e o desenho de respostas alternativas podem ser definidos em virtude dos sucessos alcançados no passado ou podem refletir lições aprendidas dos erros passados. Uma vez adotada, uma política tende a ser readotada, na medida em que passa a ser considerada a resposta natural e leva os decisores a reproduzir políticas preexistentes, apenas ajustando-as marginalmente para acomodá-las a novas situações (Heclo, 1974, apud Pierson, 1993).

As regras e os procedimentos institucionalizados na configuração que assumiu a assistência à saúde, caracterizada pela segmentação e constituição de um mix privado/público, tiveram como um dos seus efeitos a atribuição de significados à realidade e a conformação de determinadas concepções sobre o público e o privado. A experiência com determinadas práticas que se repetem no tempo configurara determinada visão da realidade, de tal forma que os padrões estabelecidos para a prestação da assistência alicerçados na prática privada passam a ser considerados como dados e tendem a ser readotados rotineiramente, de forma a naturalizar as escolhas do passado. A repetição desse padrão conforma a preferência por serviços privados e pelos padrões semiliberais que caracterizam a assistência prestada no sistema suplementar; a isso, soma-se uma representação negativa do público, traduzida na depreciação dos serviços governamentais, não necessariamente construída com base em experiências concretas. Do lado dos atores governamentais, a prática de prestação de serviços terceirizados por meio da contratação de empresas e profissionais privados aparece também como a resposta natural às necessidades vinculadas à expansão de cobertura, independentemente de esta ser ou não a forma mais eficiente e eficaz.

Adotando uma perspectiva mais sociológica, pode-se dizer que a política de saúde provê categorias e modelos de interpretação da assistência, tanto pública quanto privada, dessa maneira, provendo scripts cognitivos para essa 
interpretação, os quais informam as ações. ${ }^{6}$ Dessa forma, a opção por planos privados passa a ter uma relação com a interpretação que é feita da assistência pública e se consolida pelas imagens negativas, mesmo que nem sempre construídas com base na experiência pessoal, mas transmitidas pela difusão de representações coletivas, freqüentemente estimuladas pelos representantes dos interesses privados.

Com base nesses mecanismos é que são enfatizados os efeitos de feedback e a dependência de trajetória (path dependence) na explicação do aparente paradoxo da política de saúde brasileira. Políticas prévias explicam o desenvolvimento futuro, e legados institucionais podem inviabilizar ou, no mínimo, limitar a possibilidade de mudanças. O desenho estabelecido em algum momento para uma determinada política tem conseqüências políticas e cognitivas, de tal forma que na relação entre as políticas públicas e os processos políticos as primeiras não são apenas uma decorrência dos segundos, mas também funcionam como variáveis independentes, reordenando a disputa política e podendo até bloquear alterações institucionais. No caso da saúde, o caminho escolhido em um momento histórico como forma de garantir assistência à saúde no Brasil influenciou de forma decisiva a conformação do desenho da política atual e, ainda, as possibilidades futuras.

\section{Continuidades e Mudanças Institucionais: a relação entre contexto político, crise e idéias}

Na perspectiva analítica adotada para a interpretação da política de saúde brasileira atual, a reforma na política após a Constituição, embora configure uma ruptura institucional ao alterar os princípios que norteavam a política de saúde, a concepção de direito à saúde e as atribuições governamentais para a garantia desse direito, vai significar também grandes continuidades. Isso se

\footnotetext{
As instituições afetam em duas dimensões o comportamento: na dimensão normativa, o impacto institucional decorre do fato de os indivíduos serem socializados em papéis institucionais, daí internalizando normas associadas a esses papéis; na dimensão cognitiva, as instituições influenciam o comportamento provendo scripts cognitivos, categorias e modelos indispensáveis para a ação, sem os quais o mundo e o comportamento dos outros não pode ser interpretado (Powell \& DiMaggio, 1991; Hall \& Taylor, 1996).
} 
evidencia particularmente nos aspectos que são o objeto deste trabalho, que se traduzem na convivência entre formas públicas e privadas de assistência apesar da universalização formal da atenção pública -, bem como na articulação privado/público na prestação de serviços de saúde. Nesse sentido, não obstante as significativas transformações organizacionais do sistema de saúde e as melhorias quantitativas e qualitativas na atenção pública decorrentes da criação do SUS, as mudanças legais não significaram uma ruptura efetiva com o modelo de atenção à saúde gestado no país a partir da década de 60, desde então caracterizado como um sistema misto: público e privado. Em muitos aspectos, o modelo atual da assistência à saúde é uma continuidade do que foi estabelecido a partir dos anos 60 , de forma que a alteração constitucional não significou uma mudança de rota na assistência à saúde, considerada em sua totalidade, ou seja, considerando conjuntamente os segmentos público e privado.

Entretanto, apesar das continuidades, com a criação do Sistema Único de Saúde houve, de fato, uma inovação institucional significativa do ponto de vista interno da assistência prestada pelo setor público diretamente. Ao mesmo tempo que se realiza verdadeiramente uma reforma, essa mudança é limitada pela antiga estrutura institucional, além de não ser capaz de desmontá-la, constituindo-se, dessa forma, uma dupla trajetória: a da assistência pública e a da assistência privada. A própria Constituição expressa essa dualidade quando, ao mesmo tempo, cria o sistema público universal e define a liberdade da iniciativa privada. Em um único dispositivo, e por meio de não-decisões, o poder de veto de atores que se desenvolveram no percurso das políticas de saúde mediante os incentivos que essas políticas lhes propiciaram foi capaz de garantir as condições legais e institucionais para a preservação do modelo anterior de prestação da assistência à saúde. Ao garantir na Constituição a liberdade à iniciativa privada e ao não regulamentar a assistência privada, preservaram-se as condições para a continuidade do desenvolvimento desse segmento, apesar da definição concomitante do sistema universal e público. Isso significa que, mesmo em termos legais, o arcabouço jurídico-institucional, ao mesmo tempo que inova, também preserva as práticas institucionalizadas.

Esse caráter duplo vai ser consagrado, no final da década de 90, ao ser estabelecida uma política regulatória para o sistema privado como parte da 
política de saúde. Com essa decisão, foi legitimada formalmente a segmentação da assistência, o que até então era realizado por meio de não-decisões, deixando o setor privado crescer à margem de qualquer regulamentação - embora como conseqüência de outras decisões anteriores voltadas para a assistência pública.

Mas se os argumentos da dependência de trajetória e dos efeitos de feedback são potentes para explicar as continuidades, não são capazes de fornecer uma explicação plausível para a reforma sanitária dos anos 80 como uma inovação institucional. Ao romper com a segmentação formal e com a cidadania regulada, e ao promover uma completa reorganização do setor nos aspectos de financiamento, descentralização e gestão, houve, de fato, uma mudança institucional, em que pese a continuidade. Para a interpretação das mudanças, é preciso incorporar outros fatores ao modelo analítico esboçado até agora, os quais foram responsáveis por um desequilíbrio nas tendências históricas e capazes de propiciar que idéias inovadoras viessem a se configurar em decisões de reforma.

Dois fatores são considerados aqui para explicar a inovação institucional: um de caráter endógeno e outro exógeno à política de saúde, cada um deles com graus diferentes de importância. O determinante principal da reforma sanitária é atribuído à conjuntura política mais ampla, caracterizada pelo movimento em prol da democratização do país. Pelo caráter de excepcionalidade da situação, um movimento pela reforma sanitária foi capaz de aglutinar diferentes atores e interesses em torno de um projeto comum. No contexto de transição democrática, foram incorporadas demandas por uma democracia não apenas formal, mas também substantiva, que incluía a ampliação dos direitos de cidadania a serem garantidos por meio de políticas sociais que pudessem se traduzir em melhores condições de vida para a população. Entre esses direitos, a defesa do direito à saúde e sua tradução em propostas de inovações nas políticas se expressaram por meio de um movimento político articulado em torno de idéias fundamentadas na produção de um saber acadêmico com base nas quais foi possível constituir uma comunidade epistêmica. ${ }^{7}$ Após um

Tal como definido por Haas (1990, apud Goma \& Subirats, 1998), a comunidade epistêmica se refere a um conjunto de profissionais ou técnicos que compartilham critérios e valores ante alguns dilemas e conflitos sociais e que trabalham para que aquilo em que eles acreditam influencie políticas concretas e tenha resultados nelas. 
processo de grande mobilização política, essa comunidade portadora de um projeto sanitário inovador veio a se constituir como um grupo político capaz de influir no processo decisório, pela aglutinação de interesses diversos e de estratégias bem-sucedidas.

O contexto de transição democrática favoreceu, assim, a mudança institucional, em razão de alterações no processo político que permitiram que novos atores ganhassem visibilidade e ampliassem sua influência sobre o processo decisório. É no conflito político entre 'novos' e 'velhos' atores, portadores de interesses, idéias e propostas alternativas, que foram definidos os contornos da política de saúde. O desenho final estabelecido na Constituinte levou à convivência da ruptura com a continuidade em um processo de inovação pressionado por interesses e objetivos conformados em decorrência das políticas anteriores, de forma a limitar a possibilidade de mudanças verdadeiramente descontínuas.

Os argumentos de North (1990) sobre as possibilidades de mudança institucional são elucidativos e podem ser transpostos para a compreensão da política de saúde. Mostrando como a mudança institucional incremental afeta o conjunto de escolhas em um determinado momento, North concluiu que mesmo mudanças descontínuas nunca o são completamente, em razão dos constrangimentos informais nas sociedades, que limitam a possibilidade de ruptura institucional. Nessa perspectiva, mesmo quando há mudança, instituições nunca são construídas do nada - o mais comum é que sejam reconstruídas com base em elementos das anteriores. Mudanças nunca são completamente descontínuas, pois, mesmo que se mudem as limitações formais, permanecem as informais, inseridas em costumes, tradições e códigos de conduta que são mais impenetráveis a políticas deliberadas. Embora se desenvolvam valendose de regras formais, esses limites informais evoluem no contexto de interações repetidas. As conseqüências das políticas anteriores, associadas aos padrões de representação dos grupos de interesse, definem o contexto das reformas de políticas públicas.

A compreensão da interação entre o processo político e as estruturas institucionais vinculadas à política de saúde permite captar não apenas os aspectos de continuidade na política de saúde, mas também a possibilidade de dinamismo institucional, de forma a não entender a dependência de trajetória 
e os efeitos de feedback como determinantes absolutos das possibilidades de desenvolvimento das políticas de saúde. Incorporando a análise histórica, é possível elucidar os mecanismos causais que atuam no processo de constituição e implementação da política de assistência à saúde e fugir do risco de certo determinismo institucional. Isso porque, ao fim e ao cabo, a política é sempre resultado de escolhas definidas politicamente. E se os atores constituídos previamente são resistentes a mudanças que afetem seus interesses, outros atores podem ser introduzidos na arena política, em razão de alterações no contexto político mais amplo. Nessa perspectiva, o comportamento político é também uma variável independente, particularmente em situação de mudanças conjunturais, mesmo sendo influenciado por instituições e políticas anteriores.

O risco de uma perspectiva estruturalista em relação às instituições e às políticas públicas, que pode estar implícita nessa abordagem institucionalista e histórica, é descartado, como alertam Thelen e Steinmo (1994), na medida em que se enfatiza o papel da agência humana e da escolha, mesmo que realizada dentro de limites institucionais. Dessa forma, é possível integrar a compreensão de padrões gerais com uma explicação da natureza contingente do desenvolvimento político e econômico, destacando o papel do conflito e da escolha em modelar esse desenvolvimento. Assim, a análise histórica permite prover uma estrutura analítica para avaliar a relação entre escolhas e determinações na compreensão da vida política, entendendo instituições como produto do conflito político e de escolhas, mas, ao mesmo tempo, modelando o comportamento político; ou podendo modelar e restringir as estratégias políticas, mas também sendo resultado, consciente ou não, pretendido de estratégias políticas deliberadas.

Adaptando os argumentos de Thelen e Steinmo (1994) para a compreensão do processo de escolha da política de saúde durante o processo constituinte, considera-se que as políticas prévias não são as únicas variáveis que afetam as escolhas, embora as estruturas desenvolvidas historicamente canalizem as lutas políticas de determinadas maneiras. O dinamismo institucional (ou as mudanças da política de saúde) é entendido com base na compreensão da interação entre instituições e processo político ao longo do tempo. Ao mesmo tempo que as instituições filtram a política, seu impacto é mediado pelo contexto político. No caso da saúde, o impacto das políticas prévias foi mediado 
pelo contexto político de democratização que propiciou a mudança na política de saúde nos anos 80 ao possibilitar que determinada coalizão de interesses diversos fosse bem sucedida e tivesse poder suficiente para traduzir sua proposta em reforma - algo pouco provável em outra conjuntura. A fonte da mudança se localizou então em fatores exógenos às próprias políticas. ${ }^{8}$ Entretanto, essa mudança não foi descontínua, uma vez que carregou as marcas do passado.

Um segundo fator foi considerado para explicar a inovação institucional ou a mudança na política de saúde na década de 80 . Esboçada desde os anos 70, a crise do setor saúde foi um fator de natureza endógena à própria política, o qual forçou a busca de novas alternativas ante o esgotamento da capacidade de financiamento da assistência nos moldes em que foi estruturada e se refletia na queda da qualidade dos serviços e na insatisfação generalizada de usuários e prestadores, tanto profissionais quanto hospitais. Como destaca Gourevitch (1986), a crise é um momento especial de reformulação de política. Diferentemente dos períodos de estabilidade, quando as escolhas são limitadas, nos momentos de crise há maior liberdade de ação. Além disso, a crise engendra debates políticos e torna mais evidentes as divergências prescritivas entre diferentes atores. A crise da saúde teve como um dos seus efeitos mostrar os estrangulamentos do modelo de assistência montado, que tinha como um de seus suportes o mix privado/público. No enfrentamento da crise, o movimento sanitário foi o ator que conseguiu articular uma proposta coerente para se oferecer como alternativa em uma situação consensualmente considerada como de crise. Esse movimento soube, assim, tirar proveito dessa situação e de uma conjuntura favorável a mudanças democráticas, e colocou no debate sua interpretação da crise e sua proposta de política para a saúde.

Nesse contexto, as idéias elaboradas e difundidas pelo movimento sanitário, que indicavam uma reforma sanitária ampla e, no limite, revolucionária,

8 Esse argumento é diferente do de Krasner (1983, apud Thelen \& Steinmo, 1994), que elabora o modelo do equilíbrio interrompido para explicar a mudança institucional, desmontando os modelos estáticos de causalidades únicas. Ou seja: se as instituições funcionam como variáveis independentes em períodos de estabilidade, quando as instituições se alteram o argumento analítico é invertido, e elas se tornam variáveis dependentes, definidas pelos conflitos políticos. Os períodos de estabilidade institucional são periodicamente interrompidos por crises, que levam à mudança institucional, depois da qual recomeça o equilíbrio. 
foram capazes de constituir um projeto alternativo para a saúde e de produzir mudança na política. Entretanto, essas novas idéias foram filtradas pelas instituições e práticas de saúde já consolidadas, sendo reconfiguradas de forma a acomodar as instituições vigentes, os interesses consolidados e os processos em curso, perdendo parte de seu vigor transformador e permanecendo como metas formais ou idealizadas. No processo de formação da proposta da reforma sanitária, por meio de vários mecanismos, um conjunto de atores foi se articulando e divulgando novas idéias, acomodando-as aos diversos interesses que o movimento político foi aglutinando, de forma a ir modificando o teor da proposta no processo político que levou à reforma sanitária. ${ }^{9}$

Weir (1994) explora a relação dinâmica entre idéias e instituições políticas para analisar a inovação nas políticas, focalizando os caminhos que as idéias e os interesses materiais tomam para exercer influência no contexto institucional do processo de elaboração de políticas. Analiticamente, a questão é identificar quando e como o processo político e as idéias se combinam para produzir inovações e por que algumas idéias falham e não conseguem influenciar as políticas. A interação de idéias e política através do tempo cria um padrão limitado de inovação, no qual algumas idéias tornam-se crescentemente improváveis de influenciar as políticas públicas. Para esse processo de estreitamento, é central a criação de instituições cuja existência define o fluxo de idéias, cria incentivos para atores políticos e ajuda a determinar o significado político das escolhas. Uma abordagem histórica permite entender as maneiras como idéias e ação podem ser conduzidas por políticas prévias, como certas rotas se tornam bloqueadas, esclarecendo as conexões entre políticas através do tempo, e como oportunidades para inovação aparecem em um momento particular. As inovações são parte de uma seqüência de políticas na qual o desenvolvimento institucional torna alguma interpretação dos problemas mais convincente e explica o fato de algumas políticas serem mais viáveis do que outras.

9 As idéias têm um lugar importante na estrutura analítica do novo institucionalismo histórico. Novas idéias podem ser a fonte de mudança, levando a novos resultados ou novas políticas, o que é mediado pela configuração institucional mediante um sistema de filtros. Idéias e interesses materiais interatuam em contextos institucionais específicos para produzir mudanças de políticas, sendo necessário estudar o processo concreto por meio do qual certas idéias, e não outras, passam a dominar o discurso político e por que certos interesses prevalecem (Hall, King, Weir, apud Scokpol, 1985). 
$\mathrm{O}$ argumento de Weir sobre o padrão de inovação limitada (bounded innovation) é frutífero para interpretar a interação entre as idéias do movimento sanitário e o processo político que definiu a reforma da política de saúde. No processo de ocupação de espaços decisórios e de ampliação de alianças, nem todas as idéias inovadoras foram incorporadas, e muitas das idéias dos reformistas dos anos 80 falharam na tentativa de influenciar a política, ocorrendo um processo de estreitamento ou de ressignificação das propostas e das idéias originais. As políticas anteriores e as instituições e interesses delas originados limitaram a possibilidade de incorporação de algumas idéias, assim como modelaram esses mesmos interesses e as estratégias de seus portadores. Mas, mesmo com essas limitações, a conjuntura de crise do modelo assistencial e de democratização favoreceu o desenvolvimento institucional e possibilitou que, se não todas, grande parte das idéias do movimento sanitário fosse convincente o suficiente para promover uma reforma.

A experiência brasileira de reforma constitucional no âmbito da saúde não corrobora a idéia de uma conjuntura crítica de mudança institucional substancial que determina uma mudança de trajetória a partir dela, tal como sugerem os argumentos de Gourevitch, Collier \& Collier e Krasner (apud Hall \& Taylor, 1996). Diferentemente, meu argumento é que, na experiência brasileira, a mudança não significou uma ruptura ou o estabelecimento de uma nova rota para a assistência à saúde, pois ao mesmo tempo que se muda de forma profunda o segmento público, a mudança é limitada pela antiga estrutura e não é capaz de desmontá-la, constituindo, de fato, uma dupla trajetória.

Esse duplo movimento significa que, ao mesmo tempo que há uma ruptura institucional com a criação do SUS, não se logra eliminar as instituições vigentes anteriormente. Se a conjuntura de transição democrática e de crise da política de saúde favoreceu a mudança institucional, o legado das políticas de saúde anteriores restringiu sua implantação. As características preservadas da política de saúde anterior não o são sob a forma de uma síntese no sentido dialético do termo, mas constituem, de fato, uma dualidade. Cria-se um sistema nacional de saúde universal e com uma proposta de igualdade, mas, paralelamente, mantêm-se praticamente intocadas as instituições privadas de assistência à saúde. A regulamentação da assistência suplementar dez anos após a criação do SUS expressa essa dualidade, pois ela se fez independen- 
temente dele e ao mesmo tempo que se aprovava uma mudança constitucional com o objetivo de fortalecer o sistema público do ponto de vista de seu financiamento.

\section{Hipóteses Alternativas para a Expansão do Sistema Privado: fracasso do SUS e hipótese da convergência}

Os argumentos analíticos que conduziram esta investigação divergem, embora não sejam de todo incompatíveis, de outros que, implícita ou explicitamente, aparecem na literatura para explicar a expansão da assistência privada paralelamente à implantação da reforma universalista do sistema público. Uma das hipóteses correntes atribui esse paradoxo ao 'fracasso' do SUS em garantir assistência médica de qualidade, 'forçando' aqueles com maior capacidade de compra a adquirir planos de saúde privados (Faveret \& Oliveira, 1990; Mendes, 1993). Por sua vez, tal fracasso, que levaria a esse efeito inesperado do SUS, é atribuído, em grande parte, à ausência de financiamento adequado, em razão da crise econômica e dos reflexos das políticas de ajuste fiscal sobre o financiamento, as quais conviveram com a implantação do SUS. Essas políticas, entre outras coisas, significaram a restrição dos gastos públicos, particularmente os sociais, não apenas no Brasil, mas em diferentes países da América Latina.

Os problemas concretos para a implantação da nova política de saúde na década de 90, orientada para uma ampliação do papel do Estado, foram, às vezes, vistos como sinalizadores de um redirecionamento das atribuições públicas na área da saúde, justificável nos termos do debate internacional que passou a enfatizar as opções de políticas voltadas para o mercado. Em conseqüência, além da limitação financeira, ao contexto nacional e internacional de restrição e reformulação das políticas sociais costuma ser imputado o crescimento do setor privado ante um suposto afastamento do Estado das atividades relativas à assistência à saúde.

De fato, desde os anos 80 têm ocorrido reformas de sistemas de saúde em diferentes países em um cenário descrito como de crise. Nos anos 90, a agenda da saúde sofreu uma inflexão, e foram introduzidas, por um lado, 
questões mais administrativas e gerenciais para a reorganização dos sistemas de saúde e, por outro, a defesa de menor grau de responsabilização do Estado na provisão de serviços (Viana, 2000). Essas reformas buscaram, em maior ou menor grau, incorporar a participação do mercado na prestação de serviços de saúde, mesmo que, muitas vezes, apenas de forma residual, no bojo de propostas de 'redesenho' do Estado e em uma situação de reordenamentos ideológicos. Essas propostas de reformulação ainda em curso sugerem novas perspectivas da combinação público-privado na atenção à saúde para equacionar os elementos básicos que constituem um sistema de saúde - financiamento, gestão e prestação de serviços -, questões que envolvem, além da definição das atribuições do Estado e do mercado, a determinação dos beneficiários das políticas ou programas.

Em consonância com esse contexto, também no Brasil alguns temas surgiram na discussão da saúde, sugerindo indícios de mudanças na definição das atribuições estatais no campo da saúde, bem como das formas de articulação estado/mercado/sociedade, pouco tempo depois das mudanças constitucionais que priorizaram o papel do Estado. Questões como a seleção de prioridades, as opções entre grupos sociais e a estratificação do SUS, a natureza da função pública na saúde com a revisão dos conceitos de público, privado e estatal, a discussão de modelos alternativos de prestação de serviços e a ampliação do poder de regulação do Estado, inclusive do setor privado 'autônomo', são exemplos de como passaram a ser reapresentadas as propostas de reforma da política de saúde no Brasil (AbrES, 1994).

Nessa conjuntura de reformas, várias análises identificam uma tendência comum em todos os países da América Latina no sentido da 'privatização' da saúde. ${ }^{10}$ Apesar de o termo 'privatização' ser usado de forma imprecisa, podendo assumir diferentes significados, em linhas gerais significaria a ampliação do setor privado em detrimento do estatal e sua emergência como setor

10 Há divergências sobre o significado do termo 'privatização' quando se trata dos serviços de saúde, o qual pode incluir tanto a venda de ativos ou serviços ao setor privado quanto formas indiretas, como a gestão privada de unidades de saúde públicas, o fortalecimento do setor privado ante o público, a delegação de serviços ao setor privado ou o aumento dos seguros e dos hospitais privados. Compartilho da concepção de Polanco (1995), que considera que o termo 'privatizar' delimita um determinado tipo de ação mediante a qual as relações de propriedade, controle ou usufruto passam para as mãos de entidades jurídicas de natureza privada. Por essa definição, ficariam excluídos os processos de crescimento do setor privado preexistente a uma decisão de privatizar e que não obedecem a uma decisão política explícita de privatizar. 
hegemônico em um contexto em que a lógica mercantil teria se tornado o elemento ordenador da área da saúde (Laurell, 1995). As diferentes modalidades de privatização teriam como denominador comum a transformação da saúde de um direito de cidadania em uma mercadoria e derivariam de uma dupla necessidade: favorecer as políticas de ajuste e impulsionar a mercantilização dos setores rentáveis dos serviços de atenção à saúde (Eibenschutz, 1995). ${ }^{11}$

Estudos comparativos, apesar de reconhecerem as especificidades e os formatos assumidos pela 'privatização' em diferentes países, inclinam-se a enfatizar as similaridades das tendências, de forma que as experiências nacionais são vistas como retraduções locais de mudanças econômicas desencadeadas internacionalmente e sob influência de organismos internacionais. ${ }^{12}$

Essa linha de raciocínio sugere certa recriação da hipótese da convergência que balizou muitas das análises relativas ao desenvolvimento das políticas sociais ou do Estado de Bem-Estar e que ressurgiu na explicação da sua crise ou retração. ${ }^{13} \mathrm{O}$ reconhecimento de processos similares em diferentes países,

11 Expressão desse argumento foi a realização, em março de 1993, na Cidade do México, do II Seminário Latino-americano de Política Sanitária, cujo tema foi a articulação público/privada nos sistemas de saúde da região, assim resumido por Eibenschutz (1995: 11): "Analisamos conjuntamente qual era o traço mais característico na evolução recente dos sistemas de saúde na América Latina e concluímos que era o processo privatizador resultante do modelo neoliberal (...).”

12 Almeida (1995, 1997), analisando as reformas de saúde de cinco países europeus e dos EUA nos anos 80 , identifica uma 'mudança de paradigma' na intervenção estatal subjacente nos processos de todos os países, embora reconheça que as opções e os resultados tenham sido diferentes. Segundo ela, todas as reformas envolveram: a) reestruturação centrada na contenção de custos, controle de demanda e co-responsabilidade da população pelo financiamento; b) redimensionamento do papel do Estado e introdução de mecanismos competitivos na alocação de recursos entre prestadores; e c) novos modelos gerenciais e de organização dos serviços. Mas a autora identifica grande discrepância entre o discurso reformista e as políticas implementadas. Nos casos estudados, as reformas mantiveram a cobertura universal, o financiamento público e a responsabilidade estatal pela provisão, direta ou indireta, de serviços e o controle do Estado sobre o financiamento do sistema. Essa mesma idéia aparece em Viana (1997), sugerindo que as reformas foram muito mais no sentido de introduzir mecanismos gerenciais, mas sem alterar as bases em que foram construídos os sistemas de proteção e sem afetar os fundamentos públicos dos sistemas nacionais de saúde europeus.

13 Para explicar a expansão do Estado de Bem-Estar, a teoria da convergência postula que todas as nações industrializadas, independentemente de suas especificidades, teriam convergido para processos similares, em que o Estado teria assumido a função de garantir determinados padrões mínimos de vida - suprindo necessidades que não mais poderiam ser supridas pelas instituições sociais tradicionais - pressionado por demandas decorrentes da marginalização de certos grupos como conseqüência do impacto do desenvolvimento econômico e tecnológico na estrutura ocupacional. Da mesma forma, essa mesma teoria, que pressupõe um determinismo econômico, tem sido utilizada para analisar a retração do Estado de Bem-Estar, sendo identificada uma convergência nos padrões nacionais de política social como um dos desdobramentos da mudança econômica mundial. Sobre essa teoria, ver Faria (1998), Arretche (1995), Pierson (1993, 1994) e Esping-Andersen (1990). 
relativos à configuração do Estado e das mudanças nas formas de articulação entre Estado e mercado, tem dado margem à corroboração da 'hipótese da convergência', segundo a qual fatores internacionais são determinantes das reformas domésticas, de tal forma que, em resposta à crise econômica e à competição global, as diferenças na dinâmica da reforma de Estado não são acentuadas, havendo convergência entre as instituições de diferentes países. No caso da saúde, grosso modo, as transformações recentes na concepção de Estado, vinculadas às crises econômica e fiscal e à dificuldade de que fossem assumidos os custos crescentes das políticas de saúde, levariam a certas convergências nas políticas entre diferentes países no sentido de uma privatização, nas diversas acepções que o termo assume.

Mesmo que se possa admitir que formas de atividades privadas existam nos diferentes sistemas de saúde e que tendências nesse sentido se difundam internacionalmente, as diferenças entre os países não permitem uma interpretação que negligencie os fatores explicativos internos, de tal forma que os elementos comuns encontrados na articulação privado/público não devem obscurecer as especificidades e, muito menos, o timing dos processos privatizantes, que nem sempre acompanham o movimento de reforma do Estado. Mesmo que possa haver pressão no sentido de uniformização da agenda de reformas, é possível constatar, em contraposição à hipótese da convergência, que os países lidam de formas diferentes com essas agendas, particularmente no campo das políticas sociais, no qual é menos provável que os mercados econômicos imponham maiores imposições. Laurell (1995), por exemplo, destaca as diferenças entre os países na América Latina, existindo aqueles em que há predomínio de sistemas de saúde com financiamento e produção de serviços públicos e em que o setor privado se insere em interstícios do tecido público; outros em que o financiamento dos serviços é público, mas sua produção é privada; e alguns em que o financiamento é coletivo, mas não necessariamente público, e o setor privado é dominante na produção dos serviços. Fleury (1995) chega a identificar dois modelos polares de reforma da seguridade social na região: o universal/publicista, no Brasil, entendido como um sistema universal de inclusão segmentada na condição de cidadania; e o modelo liberal/produtivista, no Chile, no qual a Previdência Social foi totalmente privatizada e a saúde foi objeto de 
propostas de modernização, com vistas a operacionalizar um novo modelo de economia social de mercado (Labra, 1995). As características distintivas dos dois modelos no tocante à relação público/privado, além das diversas análises que mostram as distinções entre as experiências latino-americanas, parecem invalidar a hipótese da convergência sugerida, muitas vezes, pelos mesmos estudos.

Almeida (1997), por exemplo, mesmo identificando tendências internacionais comuns nas reformas sanitárias da década de 90 , conclui que, acima de aparentes semelhanças, homogeneidades e esforços de difusão de idéias e instrumentos, a dinâmica da transição é diferente em cada país, dependendo dos processos políticos subjacentes. Da mesma forma, sem negligenciar os fatores políticos, como é comum em explicações que remetem aos fatores econômicos convergentes a explicação das similaridades entre os países, também Laurell (1995) sugere que as diferenças dependem das condições políticas de cada país e do processo histórico de constituição do setor saúde. ${ }^{14}$

A constatação das diferenças entre as políticas de saúde de países submetidos a pressões econômicas e internacionais similares sugere, assim, a relevância de outros fatores explicativos, particularmente os político-institucionais, e a trajetória histórica de cada um. Refutando a idéia de uma convergência, e em consonância com o modelo analítico exposto nas seções anteriores, defendese aqui que o fortalecimento do setor privado no Brasil em detrimento da assistência pública não decorre de uma tendência atual de privatização na saúde, independentemente do significado que esse termo possa assumir. O crescimento do setor privado no Brasil - traduzido seja na prestação de serviços por unidades privadas, seja na existência de formas privadas de financiamento, gestão e acesso a serviços de saúde - é anterior ao movimento de valorização do mercado, fruto das reformas econômicas dos anos 90 no país, e, portanto, não pode ser visto como uma simples resposta às pressões e mudanças geradas na conjuntura nacional e internacional. O desenvolvimento recente da política

14 Analisando criticamente os estudos comparativos na área da saúde, Labra e Buss (1995: 15) identificam uma "crescente proliferação de tipologias que pretendem enquadrar com pouco êxito a diversidade existente; há grande dissenso quanto às variáveis determinantes das semelhanças e diferenciações entre sistemas; tem sido escassa a contribuição que as análises comparativas têm dado para a construção de uma teoria mais geral das políticas, dos sistemas e das reformas na saúde, embora a contemporaneidade, marcada pela pluralidade, esteja talvez tornando obsoletas tais pretensões totalizantes". 
de saúde encontra seus fundamentos no próprio formato institucional da prestação da assistência à saúde no Brasil, caracterizada, desde sua constituição, por formas híbridas, com justaposição ou articulação de mecanismos privados e públicos, quando foram feitas escolhas por formas privadas de assistência.

A ênfase no legado da trajetória não significa considerar que o contexto ideológico, político e econômico de reforma do Estado não tenha influência na evolução recente do SUS e da assistência à saúde no seu conjunto. Ao contrário, esse contexto tende a legitimar, reforçar ou, mesmo, aprofundar a trajetória da política de saúde brasileira, na medida em os princípios que nortearam a criação do SUS perdem a força aglutinadora que conseguiu obter no contexto anterior de refundação da democracia no país. Em conseqüência, há fortes indícios de se cristalizar a tendência da segmentação de clientelas, restando ao sistema público a responsabilidade pela assistência à saúde aos segmentos da população sem capacidade de participar do mercado privado de planos privados de saúde, atualizando, assim, as recomendações internacionais no sentido de focalizar as políticas sociais nos mais pobres.

Isso significa que as tendências de privatização e de retraimento da ação estatal, como uma das conseqüências do movimento de reforma do Estado relacionado à crise econômica a partir dos anos 80 , favorecem o aprofundamento da dualidade do sistema de saúde brasileiro, que tem muitas das características enfatizadas nas discussões normativas sobre a reforma do Estado. Entre essas características, distinguem-se, particularmente, a focalização da ação governamental nos mais pobres, a separação entre financiamento e provisão, e a delegação ao mercado do atendimento das demandas daqueles segmentos com capacidade de compra. Além disso, apesar das medidas concretas para a implantação dos dispositivos constitucionais relativos à saúde, os efeitos da aprovação de uma reforma universalista e publicista realizada na contramão das tendências dominantes de restrição das atividades estatais podem ser observados. Apesar de no discurso formal não se observar um ataque direto à universalização do acesso a ações públicas de saúde, ações governamentais concretas demonstram a inviabilização do SUS não sob a forma de uma redução programática explícita, mas sob a 'forma sistêmica', adotando aqui o argumento de Pierson 
(1994). ${ }^{15}$ Por meio de estratégias indiretas, particularmente a falta de regularidade do financiamento das ações de saúde, inviabiliza-se, na prática, a efetivação do sistema público, principalmente quando se considera a ampliação formal da demanda a partir da definição do acesso a serviços de saúde como parte fundamental do direito à saúde, consagrado na Constituição. $\mathrm{Na}$ conjuntura pós-transição democrática, os fatores explicativos para a falta de financiamento adequado para o SUS vinculam-se ao ambiente político e econômico geral, particularmente a efetiva crise econômica e a dificuldade de ampliação da capacidade de gasto do governo, mas também às características da coalizão conservadora que dominou os primeiros governos democráticos afinados com as propostas de restrição das políticas sociais. Todos esses fatores sistêmicos contribuem para a compreensão do formato institucional da assistência à saúde no Brasil e reforçam as características adquiridas ao longo de sua trajetória.

\section{A Regulação como Consolidação da Trajetória}

Particularmente em um aspecto a política de saúde brasileira atual vai refletir a influência da agenda internacional e dos princípios normativos que embasam as reformas do Estado das últimas duas décadas. O diagnóstico da crise do Estado, vista como articulada à crise de formas anteriores de regulação estatal, traduziu-se em reformas nos modelos de gestão pública, entre elas as alterações dos mecanismos institucionais de regulação governamental. Como contrapartida da diminuição das funções executoras do Estado, a agenda internacional passou a enfatizar o papel regulatório do Estado em detrimento da produção direta de serviços, como forma de intervencionismo estatal mais

\footnotetext{
15 A idéia de inviabilização sistêmica está sendo aqui usada por analogia com a noção de redução sistêmica das políticas do Estado de Bem-Estar, utilizada por Pierson. Com essa expressão, Pierson se refere às estratégias indiretas para redução de políticas cujas conseqüências se fazem sentir apenas em longo prazo e que parecem ter sido muito mais importantes nas tentativas de desmantelamento do Estado de Bem-Estar do que os esforços de redução programática explícita dos programas sociais. Pierson identifica como a forma mais importante de redução sistêmica do Estado de Bem-Estar americano, a partir do governo Reagan, a sua descapitalização parcial via reformas tributárias, que enfraqueceram a possibilidade de o governo federal financiar os programas sociais.
} 
adequada às mudanças institucionais decorrentes da transição de um modelo de desenvolvimento calcado no Estado para outro voltado para o mercado. A reintrodução na agenda pública da questão da regulação vincula-se, assim, à necessidade de substituir a intervenção direta do Estado no mercado e na sociedade por outras formas consideradas menos intervencionistas. No caso da privatização da produção de serviços públicos ou de grande interesse público, a regulação tendeu a ser exercida por organizações autônomas - as agências reguladoras -, às quais, de acordo com as premissas que justificam a nova forma de intervenção, credita-se maior eficiência. Acompanhando as experiências internacionais, essa foi a opção brasileira quando definiu-se uma política regulatória para a assistência privada no final da década de 90.

De acordo com o argumento aqui defendido, o novo marco regulatório criado para as atividades privadas no âmbito da saúde, que até então se desenvolviam praticamente à margem de qualquer regulamentação governamental, não indica uma mudança estrutural na forma de atuação governamental no âmbito da saúde no sentido preconizado pelas reformas na concepção e forma de atuação do Estado que caracterizaram o período. Embora não deixe de traduzir essa mudança de concepção, a regulamentação do setor privado não é o resultado de uma suposta 'saída' do Estado brasileiro em decorrência de um processo de privatização da saúde; ao contrário, passa-se a regular uma atividade privada que já existia desde os anos 60 , e a regulação do mercado não elimina a atuação estatal anterior, baseada na ação direta e em uma perspectiva redistributiva, expressa na concepção original do SUS.

Mesmo considerando que a regulação não tenha sido o resultado de uma privatização do setor, o formato institucional assumido pela regulação da assistência suplementar sob a forma de uma agência reguladora independente reflete o contexto de reforma do Estado e dos mecanismos de gestão pública que caracterizam a década de 90 no Brasil, em sintonia com os modelos e concepções normativas desenvolvidos e difundidos internacionalmente. Entretanto, a modificação no padrão regulatório com a criação da Agência Nacional de Saúde Suplementar, substituindo a auto-regulação pelos próprios agentes do mercado de saúde, não eliminou outros instrumentos de regulação que já operavam anteriormente, como a propriedade pública de unidades de 
saúde e a regulação do setor privado prestador de serviços no interior da burocracia executiva; ao contrário, passou a conviver com eles. Essa combinação de instrumentos regulatórios sustenta a idéia da constituição de uma dupla trajetória da assistência à saúde, uma vez que a política regulatória não visou articular os dois segmentos da assistência - o público e o privado - nem definir os espaços respectivos de atuação, mas consagrou a sua independência. Nesse sentido, também refletiu o legado das políticas anteriores. O resultado foi a consolidação da segmentação da assistência, que, a partir da regulação do setor privado, foi incorporada à própria política de saúde. A conseqüência é o enfraquecimento político e ideológico dos pressupostos e objetivos associados à criação do SUS, particularmente a responsabilidade estatal pela saúde e a universalização do acesso à atenção pública.

\section{Síntese das Proposições, Estratégia de Análise e Estrutura do Trabalho}

\section{Hipótese geral e proposições}

Em síntese, considerando o principal argumento de que os legados institucionais de políticas previamente estabelecidas condicionam o processo de reformulação das políticas, que são assim dependentes de sua própria trajetória, para a interpretação da política de assistência à saúde vigente no Brasil - especificamente no aspecto do mix privado/público que a caracteriza, entendendo-se por isso a convivência entre formas públicas e privadas de assistência -, este estudo parte da seguinte hipótese geral: o formato institucional híbrido da assistência à saúde, apesar da definição constitucional de um sistema público, universal e único, é explicado, em grande parte, pelos legados das políticas de saúde estabelecidas a partir dos anos 60. Tais legados condicionaram o desenvolvimento posterior da assistência e limitaram a possibilidade de mudanças, em razão de três efeitos principais: primeiro, ao estruturar os interesses privados na saúde, configuraram o conflito político e o processo decisório posterior, delineando as disputas por alternativas de políticas; segundo, as políticas prévias estabeleceram determinados padrões de comportamento difí- 
ceis de reverter; e terceiro, tiveram efeitos cognitivos e sobre a capacidade governamental, pouco favoráveis à mudança de trajetória. ${ }^{16}$

Essa hipótese geral se desdobra em várias proposições inter-relacionadas, que expressam os mecanismos por meio dos quais são observados os efeitos de feedback das políticas anteriores sobre a política de assistência à saúde atual e, também, fornecem uma explicação para o aparente paradoxo da política de saúde brasileira e para os limites da reforma estabelecida durante o processo constituinte e implantada na década de 90:

1) Embora o arranjo institucional consolidado na política de assistência à saúde seja resultado de escolhas entre diferentes alternativas disponíveis, essas escolhas, realizadas em diferentes momentos de inflexão da política de saúde, foram limitadas pelos efeitos institucionais das escolhas anteriores.

2) A própria conformação da arena política da saúde em que se dá o conflito entre alternativas decorre de políticas anteriores, as quais contribuíram para a constituição de diferentes atores e interesses, em razão dos incentivos oferecidos e dos benefícios concedidos aos atores afetados pelas políticas.

3) Ao ter como conseqüência a formação de grupos de interesse, as políticas de saúde estabelecidas estimularam também a organização e a constituição de atividades desses grupos, inibindo a formação ou expansão de outros. É nesse sentido que as políticas definidas em um momento no tempo estruturaram o processo de tomada de decisões e criaram coalizões de suporte que efetivamente protegem os arranjos institucionais estabelecidos, tendo efeitos de feedback no processo político.

Essa perspectiva analítica se aproxima do modelo de políticas martingales. De acordo com esse modelo, reconhece-se que os eventos históricos envolvem elementos de acaso, sendo possível ver o processo de decisão política como um 'processo experimental independente', o que significa que eventos de hoje são independentes dos eventos de ontem. Entretanto, nem todos o são, uma vez que muitos se configuram como 'processos martingales' - ou seja, mesmo que os eventos sejam sujeitos a variações do acaso, essas variações vão se acumulando de tal forma que o valor esperado do processo em um tempo é igual à realização do processo no tempo precedente. Essa propriedade torna a trajetória histórica importante para entender os eventos históricos correntes e significa que flutuações da história ao acaso mudam as linhas básicas do próximo degrau do processo histórico. Daí se concluir que as decisões não são independentes de fatores institucionais, de sorte que as políticas, uma vez adotadas, estão mergulhadas em instituições que são associadas com regras, expectativas e comprometimentos que, afetando as aspirações, afetam o comportamento futuro dos atores políticos (March \& Olsen, 1984). 
4) As políticas de saúde configuraram uma estrutura institucional para sua implantação e condicionaram determinados comportamentos. Nessa medida, contribuíram para a formação dos objetivos e das preferências dos atores afetados pela política, tendo o efeito de dificultar o abandono de certa trajetória, tornando quase inacessíveis as alternativas que alterassem radicalmente o padrão de comportamento vigente.

5) A forma histórica de desenvolvimento da assistência não favoreceu a constituição de uma identidade coletiva entre o público-alvo da política capaz de articular uma demanda universalista. Ao contrário, propiciou a corporativização das demandas de saúde.

6) A opção anterior pela compra de serviços de prestadores privados não permitiu que fosse desenvolvida a capacidade prestadora do governo, tendo como um dos seus efeitos tornar o setor público dependente dos serviços privados, colocando limites estruturais à mudança de trajetória.

7) As regras e os procedimentos institucionalizados na configuração que assumiu a assistência à saúde, caracterizada pela segmentação e pela constituição de um mix privado/público, teve como outro de seus efeitos a atribuição de significados à realidade e a conformação de determinadas concepções sobre o público e o privado, de tal forma que os padrões estabelecidos tendem a ser readotados, naturalizando as escolhas do passado e conformando a preferência por serviços privados.

8) A reforma na política de saúde após a Constituição, embora seja uma ruptura institucional ao alterar os princípios que norteavam a política anterior, vai significar também grandes continuidades, particularmente a convivência de formas públicas e privadas de assistência. Ao mesmo tempo que se realiza, de fato, uma reforma, essa mudança é limitada pela antiga estrutura institucional e não é capaz de desmontá-la, constituindo-se realmente uma dupla trajetória: a da assistência pública e a da privada.

9) A reforma da política de saúde que levou à criação de um sistema público universal é explicada pela confluência de dois fatores: crise do financiamento da assistência; e mudanças no contexto político mais amplo. $\mathrm{O}$ contexto de democratização permitiu a constituição e influência no processo decisório de novos atores, portadores de propostas alternativas 
para a saúde, em uma situação de desequilíbrios institucionais favorável à inovação institucional, mas que, pelo legado anterior, tendeu a inovações limitadas.

10) O caráter dual da assistência é consagrado e legitimado no final da década de 90 com o estabelecimento de uma política regulatória para o sistema privado como parte da política de saúde que formaliza a segmentação e institucionaliza, de forma legal, a trajetória da política de saúde, enfraquecendo os princípios igualitários do SUS.

11) A regulação das atividades privadas de assistência à saúde não expressa uma convergência com o movimento difundido internacionalmente pela privatização da saúde, embora o modelo regulatório, que assumiu o formato institucional de uma agência reguladora, expresse a influência do contexto político e ideológico de reforma do Estado que caracteriza o período.

\section{Estratégia analítica, fontes e estrutura do trabalho}

Valendo-se da noção de dependência de trajetória, a estratégia analítica consistiu em realizar uma reconstituição histórica da trajetória da assistência à saúde no Brasil, articulando a seqüência de processos decisórios com o contexto institucional das políticas de saúde anteriores, entendendo as decisões como resultado das relações entre a atuação dos atores afetados pelas políticas e as limitações institucionais - entre elas, a forma de atuação do Estado -, com base nas quais são feitas as escolhas.

A perspectiva histórica é que permite analisar a relação entre as políticas prévias e as escolhas recentes, identificando os mecanismos por meio dos quais as políticas de saúde definidas anteriormente afetaram o seu desenvolvimento posterior, particularmente ao influenciar o processo político não apenas por constituir atores e interesses, mas também por condicionar a formação de suas preferências e modelar as interações e as estratégias políticas dos grupos beneficiados por ela, de tal forma que as transformações da política passaram a fluir nos parâmetros determinados pelo próprio formato da política.

Do ponto de vista teórico-metodológico, a identificação desses mecanismos, implícitos no modelo analítico utilizado, permite transcender a simples 
descrição de fenômenos históricos singulares e fornecer uma explicação plausível para eles, validando a pertinência de determinados argumentos teóricos e conciliando a descrição de processos históricos com a explicação causal fundamentada em um modelo teórico explícito que guia a escolha dos fatores explicativos e a seleção dos componentes empíricos.

Em razão da perspectiva analítica adotada, a direção da pesquisa procurou partir das políticas de saúde e identificar a presença ou não de ligação da política com as atividades de grupos específicos. Para isso, o estudo focalizou três momentos constitutivos de desenhos institucionais na política de assistência à saúde, que são:

1) Década de 60: esse período é caracterizado pela montagem e expansão do 'modelo médico assistencial privatista', assim denominado pela literatura comum na área de saúde. A política de assistência à saúde então estabelecida implicou a opção pela compra de serviços privados com financiamento do Estado. Com isso, estruturaram-se diferentes atores privados a partir dos incentivos fornecidos pela política de saúde e constituíram-se interesses, formas de organização desses interesses e instituições privadas de saúde; correlatamente, não se desenvolveram capacidades estatais para a prestação de serviços de saúde públicos, principalmente no nível da atenção secundária e terciária. Nesse período, as instituições privadas de assistência à saúde, a princípio constituídas de forma vinculada à política governamental, progressivamente foram se tornando autônomas.

2) Década de 80: caracterizada pela reforma do sistema de saúde como resultado de um amplo movimento social em prol de uma reforma sanitária, no bojo de um processo de transição democrática que enfatizava não apenas a retomada do Estado de direito, mas também a ampliação dos direitos de cidadania com a incorporação de direitos sociais, entre eles o direito à saúde. Apesar de configurar uma reforma radical em termos legais, no formato global da assistência à saúde, mantiveram-se praticamente inalteradas as características do mix privado/público. $\mathrm{Na}$ mesma década, deu-se a expansão da assistência privada por meio de diferentes formatos institucionais. 
3) Década de 90: fase de implantação da reforma do sistema público prevista na Constituição. Ao mesmo tempo, ocorre o processo de regulação do setor privado, com a intenção de incentivar o desenvolvimento do mercado de planos de saúde.

O período coberto pela pesquisa vai de 1960 até os dias de hoje, com pequena incursão aos anos 30, e as fontes utilizadas foram de diferentes naturezas. ${ }^{17}$ Em primeiro lugar, recorreu-se à bibliografia setorial, buscando fazer uma releitura a partir do fio condutor que norteou esta análise, valendo-se das informações disponibilizadas por essa literatura, particularmente para o período de 1960 a 1980.

Para a análise do processo político vinculado à arena da saúde, foram utilizados, além de fontes bibliográficas, os dados do sistema de informações do Congresso Nacional relativos a três processos decisórios cruciais: o processo constituinte, a regulamentação dos planos privados de saúde e a aprovação da Emenda Constitucional 29, que vincula recursos para a saúde. Nesses casos, foram pesquisadas, particularmente, as notas taquigráficas das audiências públicas, a tramitação dos projetos nas comissões e as discussões em plenário. Foram também realizadas entrevistas com alguns atores representantes de diferentes setores e coletadas informações sobre as organizações de interesses dos setores ligados ao mercado privado de saúde.

Por fim, foram utilizados documentos de diferentes origens, publicações oficiais, legislação e outras fontes impressas. O grande esforço de pesquisa tornou-se necessário ante o escopo da análise e em face da perspectiva histórica que informa o trabalho.

Nos capítulos seguintes, é desenvolvida a análise da trajetória da assistência à saúde, enfatizando o aspecto da relação público/privado. O fio condutor é a identificação dos processos que são conseqüências da política definida

\footnotetext{
Neste livro foi excluída, por questão de espaço, uma parte da tese na qual se buscou caracterizar a assistência à saúde no Brasil, no sentido de dimensionar os dois subsistemas que a compõem (o público e o privado) em relação à cobertura, à capacidade instalada e ao perfil das respectivas clientelas. Para essa caracterização, foram utilizadas diversas fontes: os microdados da Pesquisa Nacional por Amostra de Domicílios (PNAD/IBGE) de 1998, a qual incluiu um suplemento específico sobre saúde; dados da Pesquisa de Assistência Médica Sanitária (AMS/IBGE), utilizando toda a sua série histórica, que cobre o período de 1976/99, o qual permite quantificar a rede de serviços de saúde, tanto privada quanto pública; dados do Ministério da Saúde; e dados das entidades representativas das operadoras de planos de saúde privados. Para consulta, ver Menicucci (2003).
} 
nos anos 60, os quais, de forma cumulativa e interativa, vão configurando a moldura institucional em razão da qual as decisões são tomadas. Esses capítulos foram estruturados de forma a mesclar a análise sincrônica com a temática, uma vez que a lógica desses processos não foi apreendida de forma linear. No capítulo 2 , é analisada a constituição do mix privado/público na assistência à saúde, enfocando as decisões governamentais, com vistas à expansão da assistência pública, que levaram à constituição de determinada estrutura institucional e estabeleceram regras para a prestação da assistência, apesar da existência de propostas alternativas quanto à forma de prestação de serviços. A análise desenvolvida nesse capítulo é que dará fundamentação ao argumento desenvolvido para explicar a política atual, e o período analisado cobre as décadas de 60 e 70. Mais do que explicar a constituição do modelo de assistência, o objetivo principal é descrever a configuração institucional e política decorrente da política definida, que fornecerá a chave interpretativa das características da reforma e da trajetória posterior - ou seja, entender como uma seqüência de decisões se desenvolve, como se objetiva em instituições e como conforma atores e interesses. Em outras palavras, esse capítulo visa apresentar a variável independente - as políticas prévias - que permite explicar, em grande parte, as características da política atual de assistência à saúde.

O capítulo 3 faz um corte na análise da trajetória da política de saúde e focaliza a gênese e a expansão das formas privadas de assistência à saúde, em grande parte, em razão de incentivos e escolhas governamentais. Mesmo que esses processos sejam articulados às políticas de saúde, ao fazer esse corte temático a análise busca apreender a dinâmica do setor privado em uma perspectiva longitudinal, que vai das suas origens mais remotas até o presente. Além de descrever e mensurar o setor privado, os objetivos consistem em identificar os atores e interesses que constituem a arena da saúde e as práticas e os comportamentos desenvolvidos (como efeitos lock-in das políticas públicas), constituindo uma rede complexa de atores, organizações e beneficiários da assistência privada.

O capítulo 4 retoma a análise da trajetória da política relativa à assistência à saúde a partir de meados da década de 70 , caracterizada tanto pelo aprofundamento dos traços antigos quanto pelo surgimento de propostas alternativas, que se expressam em um movimento político e de idéias que se 
afirmam no processo constituinte. Em razão de uma conjuntura favorável, que possibilitou um desequilíbrio de tendências nos arranjos institucionalizados, de forma intencional se modelou um novo desenho para a política de saúde. Esse processo, associado às 'regras do jogo', definidas pelas decisões e pelos processos anteriores, fornece a interpretação dos novos arranjos estabelecidos nos anos 80, caracterizados, ao mesmo tempo, por suas rupturas e continuidades. Em suma, o capítulo trata dos efeitos de feedback das políticas anteriores sobre a reforma dos anos 80 , elucidando os mecanismos por meio dos quais eles atuam. Ao mesmo tempo, procura-se explicar a ruptura institucional e as continuidades do novo modelo de assistência estabelecido; a primeira, explicada pela conjuntura de democratização e de crise, e as segundas, pela dependência de trajetória. O período analisado vai até o final da década de 90, correspondente à implementação da reforma constitucional, quando os mesmos efeitos vão continuar operando.

O capítulo 5 discute o processo de constituição de uma política regulatória voltada para o segmento privado da assistência, que, ao introduzir formalmente a assistência privada no escopo da política de saúde, consagra a dualidade do sistema de assistência à saúde no país, sendo a expressão acabada de toda a sua trajetória. Esse processo reflete de forma objetiva os efeitos de feedback nos seus diversos mecanismos e indica a influência do contexto de reforma do Estado na escolha do instrumento regulatório. Isso não significa, contudo, o abandono dos instrumentos anteriores de intervenção governamental, particularmente a propriedade pública. Em suma, a regulação consolida a dupla trajetória da assistência.

Por fim, o capítulo 6 apresenta uma síntese das principais conclusões a que foi possível chegar, apresentadas ao longo do trabalho, que articulam as evidências históricas com os argumentos analíticos propostos inicialmente e fornecem uma explicação plausível para as contradições da política de saúde brasileira. 


\section{A Constituição do Mix Privado/Público na Assistência à Saúde}

Se decisões governamentais em um determinado tempo modelam o processo político subseqüente e têm efeitos institucionais, na medida em que definem 'regras do jogo' e em razão disso são potentes para explicar as políticas posteriores, o percurso analítico para explicar o formato institucional contemporâneo da assistência à saúde no Brasil deve partir dessas decisões, ou seja, do momento constitutivo dessa política pública, e a partir daí ir reconstruindo as relações das políticas públicas com o processo político-decisório posterior.

Em razão disso, este capítulo analisa o processo histórico de constituição do modelo de assistência à saúde no Brasil como um componente específico das políticas de saúde ao qual se limita este estudo. Será essa análise que dará fundamentação ao argumento desenvolvido para explicar os paradoxos da política atual. Visa-se analisar, especificamente, a constituição do mix privado/ público na assistência à saúde e seus desdobramentos em termos da estrutura institucional desenvolvida em decorrência das decisões governamentais no sentido de expandir a assistência pública a partir, principalmente, da década de 60 . Não se tratará aqui de buscar explicar, em termos de sua causalidade, a gênese da assistência pública na forma de um modelo que, desde então, assume as características de um mix privado/público. O que se pretende é descrever a configuração institucional e política decorrente de uma seqüência de decisões que fornecerá a chave para a interpretação da trajetória posterior e, fundamentalmente, dos limites que vão se estabelecer para a reforma sanitária a partir dos anos 80. De acordo com o argumento analítico que guiou este estudo, é 
necessário partir da identificação das escolhas do passado, uma vez que as escolhas posteriores serão constrangidas pelas primeiras. Isso significa que o relato histórico é também uma construção analítica com base nos meus argumentos teóricos que justificam o corte temporal realizado, na medida em o ponto de partida é a década de 60 , embora não se deixe de remeter aos anos 30 , quando é possível identificar as origens mais remotas do modelo gestado posteriormente.

Em síntese, este capítulo visa discutir a variável independente - as políticas de saúde prévias - consideradas aqui como de grande poder explicativo do formato da assistência à saúde atual, que tem como uma de suas características a existência de um sistema dual, composto por um segmento público formalmente universal e um setor privado autônomo, ambos fortemente institucionalizados e regulados. Essa variável se desdobra em diferentes processos que definem as suas características e efeitos, os quais especificam algumas das proposições analíticas mais gerais definidas no capítulo anterior:

1) As opções governamentais relativas à assistência à saúde no âmbito das instituições previdenciárias, a partir dos anos 30, mas particularmente a partir dos anos 60, favoreceram a constituição de uma determinada articulação entre a assistência pública e a privada, e principalmente a expansão do setor privado. Isso se deu tanto no caso do setor privado prestador de serviços de saúde, que passou a ter no setor público a garantia de um mercado cativo, quanto no setor empresarial organizador de formas privadas de assistência, também este sendo incentivado por meio da alocação de recursos financeiros públicos, que propiciaram o desenvolvimento de formas coletivas e empresariais de assistência, vinculadas à inserção no mercado de trabalho. Esses incentivos governamentais terão, assim, o efeito de contribuir para o estabelecimento de certos padrões de comportamento e de determinados investimentos por parte de atores privados do setor saúde, como efeitos lock-in das opções prévias, criando trajetórias difíceis de serem mudadas. Em conseqüência, essas opções governamentais influenciaram a constituição de atores e a estruturação dos interesses privados, e nessa medida condicionaram os conflitos políticos posteriores relativos às políticas de saúde ao estruturar a arena setorial. 
2) Ao optar pela compra de serviços privados para expandir a assistência pública, outra conseqüência da política estabelecida nesse período foi o baixo desenvolvimento das capacidades estatais para a produção de serviços de saúde compatíveis com a trajetória de ampliação crescente da cobertura pública. Um efeito de feedback dessa opção será a crescente dependência governamental do setor privado, o que tornará o setor público vulnerável às pressões privadas e minará sua capacidade regulatória, em contexto de forte penetração dos interesses privados na burocracia previdenciária.

3) A expansão da assistência médica se deu a partir da segmentação entre os trabalhadores, objeto das políticas. A forma corporativa que caracterizou a criação e a expansão da previdência social brasileira, e vinculada a ela a assistência à saúde de maior proporção, expressou-se como uma conquista ou uma concessão para grupos particulares de trabalhadores inseridos no mercado formal de trabalho. Dessa forma, na sua origem, a assistência médica pública não se constituiu em razão de objetivos universalistas e igualitários, e ao longo do tempo foram se desenvolvendo formas variadas de segmentação, que se traduziam na inserção em instituições de saúde diferentes. Uma das conseqüências dessa segmentação institucional foi a ausência de uma efetiva solidariedade entre os trabalhadores e de uma consciência de interdependência, de forma a constituir uma coletividade. ${ }^{18}$ Isso vai se traduzir posteriormente na ausência de uma sustentação política efetiva, embora ela se desse formalmente, dos trabalhadores organizados a um sistema de saúde público universal.

O capítulo foi construído, principalmente mas não exclusivamente, com base em uma releitura da vasta literatura disponível. A partir da segunda metade da década de 70, floresceu no Brasil a pesquisa em saúde coletiva e desenvolveu-se uma vasta produção analítica sobre as políticas de saúde, no contex-

\footnotetext{
Situação que é diferente da identificada por Hochman (1998) ao analisar as políticas de saúde pública no Brasil da Primeira República. Um de seus pressupostos, e que sua pesquisa permite comprovar, é que as políticas públicas e nacionais de saúde resultaram da difusão e da consciência da interdependência, dos dilemas e problemas impostos pelo consumo de males públicos e pela produção de bens públicos e das oportunidades vislumbradas de obtenção de benefícios com a regulação estatal desses efeitos negativos. Se isso é bastante plausível para o caso das políticas de saúde pública, de caráter coletivo, não se aplica ao caso da assistência à saúde de caráter individual, na qual a segmentação e a corporativização foram a marca, de forma a fortalecer visões e demandas particularistas.
} 
to de um grande debate em torno da 'capitalização da medicina' e do sistema previdenciário. Nesse período, foi produzida uma bibliografia significativa, que destacava entre os temas analisados a participação do setor privado no sistema público de prestação da assistência à saúde de caráter individual, a qual buscava evidenciar as articulações econômicas e ideológicas da prática sanitária em uma perspectiva histórico-estrutural. Alguns desses estudos praticamente se tornaram referências obrigatórias para todos que em algum momento se debruçaram sobre a compreensão das políticas de saúde brasileiras, e suas conclusões praticamente constituíram quase um consenso no campo analítico de maior relevância na área da saúde.

Os principais argumentos teóricos presentes nessas análises convergem no sentido de identificar a forma de expansão dos serviços de saúde como condicionada às necessidades de reprodução do capital no setor saúde, a partir do reconhecimento do caráter de classes das sociedades modernas - ponto de partida que ilumina a compreensão dos determinantes da intervenção estatal na sociedade e também na saúde. Vista como uma atividade econômica, a produção de serviços de saúde torna-se, com a ação estatal, um espaço importante para a acumulação capitalista pela integração entre empresas médicas e o Estado. Nessa perspectiva, a política assistencial acolheu os interesses dos prestadores privados de serviços e das empresas médicas ao privilegiar a prestação privada de serviços, mesmo que com a responsabilidade e o financiamento públicos, em vez de expandir a rede pública. Nesse sentido, a ação governamental se tornou instrumental aos interesses capitalistas, condicionada às preferências das classes dominantes.

Sem polemizar com as interpretações presentes nessa literatura, que em grande medida refletem as tendências teórico-explicativas dominantes no período e trazem a marca de um certo anacronismo dos esquemas analíticos, ${ }^{19}$ buscou-se aqui inverter a questão e indagar se as ações governamentais também não teriam condicionado o mercado político, de tal forma que o Estado não pode ser considerado apenas como refém dos interesses econômicos dos empresários do setor de saúde. Sem negar os interesses privados previamente

\footnotetext{
19 A marca característica de grande parte da produção teórica dessa fase é ter se constituído como um 'saber militante', o que, se do ponto de vista político valoriza essa produção, não o faz sem outros riscos do ponto de vista analítico.
} 
constituídos, a política dos anos 60 não é entendida aqui como uma relação causal simples entre interesses econômicos e a criação de um determinado formato da política de saúde. Ao contrário, a política estabelecida contribuiu para a própria configuração do Estado, além de ter estruturado determinados interesses e gerado comportamentos fortemente imbricados ao setor público.

Apesar dessa inversão analítica, este capítulo tem como principal referência empírica os textos de maior repercussão normativa e/ou teórica dessa literatura produzida nos anos 70 e 80 , visando recuperar a história das políticas de saúde do Brasil, especificamente o estabelecimento e o desenvolvimento do desenho institucional da prestação de serviços no âmbito das instituições previdenciárias, que teve como uma de suas características centrais a participação, de forma diversificada, do setor privado. ${ }^{20}$

\section{Antecedentes Históricos da Política de Assistência à saúde: a vinculação com a Previdência Social - segmentação e vinculação ao contrato de trabalho}

A expansão da assistência médica individual no Brasil como política pública faz parte do processo de montagem e desenvolvimento da Previdência Social. A estruturação do sistema previdenciário, de forma incipiente a partir dos anos 20 e mais intensamente a partir dos 30, é o marco básico do sistema de proteção social montado no Brasil, por meio do qual se desenvolveu a sustentação pelo Estado dos direitos sociais.

$\mathrm{Na}$ medida em que se desenvolve incorporada aos benefícios previdenciários, ainda que de forma incipiente, a assistência médica de maior escopo, desde sua origem, vai ter as marcas da estrutura institucional da Previdência Social da qual fazia parte. Entre elas, a segmentação de clientelas, com a

\footnotetext{
Entre os livros mais difundidos e cujo referencial empírico será utilizado neste estudo destacamse os trabalhos clássicos de Braga e Paula (1981), Cordeiro (1984), Donnangelo (1975), Luz (1986), Oliveira e Teixeira (1986), Possas (1981), Rezende e Mahar (1974). A maioria dos dados empíricos, documentais e estatísticos utilizados neste capítulo foi extraída dessa literatura, que, apesar das limitações justificadas pelas dificuldades de informações daquele período, é rica em evidências empíricas, sendo alicerçada em documentos, entrevistas, pronunciamentos, publicações da imprensa, seminários, congressos e dados obtidos em fontes governamentais. Em conseqüência, eles são suficientes para permitir uma caracterização institucional do mix privado/público no período que vai da década de 60 até a de 80 .
} 
correlata diferenciação das formas e dos serviços de saúde prestados aos diversos segmentos de trabalhadores que vão sendo incorporados, paulatina e diversificadamente, à Previdência Social. E, o que é fundamental, a assistência médica governamental se desenvolve como um benefício vinculado ao contrato de trabalho formal e com as características de seguro, ou seja, uma obrigação contratual de caráter contributivo, não se constituindo como uma prestação pública a que tem direito toda a população.

A expressão mais evidente dessa perspectiva securitária é a dicotomização que se estabeleceu na política de saúde brasileira até o final da década de 80, expressa em uma diferenciação funcional e institucional. Ao Ministério da Saúde couberam as ações de caráter coletivo que desde o início do século XX se difundiram no Brasil, sob a forma do 'sanitarismo campanhista'. ${ }^{21}$ À Previdência Social, nos diversos formatos institucionais que assumiu ao longo de sua trajetória, coube a assistência à saúde de caráter individual, restrita aos segurados e seus dependentes.

As primeiras instituições previdenciárias surgidas por iniciativa estatal para os trabalhadores do setor privado, uma vez que já existiam diversas iniciativas voltadas para funcionários públicos, são as Caixas de Aposentadorias e Pensões (CAPs), criadas nas empresas a partir de 1923 por determinação governamental e com a participação de recursos públicos. Nas CAPs já estava prevista a prestação de alguns serviços médicos aos trabalhadores cobertos e seus dependentes na condição de filiados ao seguro social, embora a legislação não especificasse a forma nem os recursos disponíveis para essa finalidade. A assistência era, entretanto, restrita aos trabalhadores vinculados às empresas com mais de cinqüenta empregados para as quais havia a obrigatoriedade de criação de caixas. A forma de provisão dos serviços médicos se fazia desde então pela compra de serviços privados, escolha que foi justificada pela fragmentação do seguro social por empresa que tornava impraticável, do ponto de vista de escala, a manutenção de serviços próprios. ${ }^{22}$

21 Cabe ressaltar que ações de assistência médica eram também desenvolvidas no âmbito do Ministério da Educação e Saúde até 1953 e, a partir daí, pelo Ministério da Saúde, mas de caráter e escopo bastante restritos e que não foram objeto deste trabalho.

22 Se entendemos que as decisões são resultado de escolhas entre alternativas, mesmo que estruturadas segundo parâmetros institucionais de diferentes ordens, é possível especular que outras escolhas poderiam ter sido feitas. 
Na década de 30, o sistema previdenciário brasileiro passa por profunda reformulação, com a criação dos Institutos de Aposentadorias e Pensões (IAPs), que sucederam e foram absorvendo as CAPs. Em vez de serem vinculados a uma empresa como as caixas, os IAPs incorporam, cada um deles, uma categoria profissional e passam a ser de caráter nacional. Os efeitos da criação sucessiva de vários IAPs em relação à assistência médica consistiram, por um lado, em possibilitar a ampliação da assistência, ao estender a cobertura previdenciária às diferentes categorias profissionais, e, por outro, em institucionalizar a diferenciação dessa assistência conforme a categoria de trabalhadores, reproduzindo na saúde as diferenciações observadas nas características gerais de cada instituto. Até sua unificação, em 1966, as instituições previdenciárias eram marcadas pela heterogeneidade, em relação tanto à legislação específica quanto ao número de segurados, à arrecadação e às despesas, apesar de ser generalizada a precariedade das condições financeiras.

Essa nova estrutura previdenciária é implementada juntamente com a legislação trabalhista e sindical durante o governo Vargas, que, em conjunto, constitui a nova forma de regulamentação da relação capital/trabalho. ${ }^{23}$

\footnotetext{
3 As interpretações mais consagradas sobre a origem da Previdência Social brasileira identificam dois fatores explicativos principais, intimamente relacionados. Por um lado, o surgimento do modelo previdenciário brasileiro é visto como um projeto da classe empresarial, interessada em garantir condições mínimas de estabilidade aos trabalhadores, contendo conflitos e tensões que ameaçavam despontar no seio da classe operária em processo de crescente organização. Dessa forma, é conseqüência de uma tentativa da elite no poder de esvaziar a agitação operária mediante um enfoque reformista da questão social e sob a forma de concessão de direitos (Possas, 1981; Malloy, 1976; Cohn, 1981, 1996). Por outro lado, essa concessão sugere o atendimento de demandas históricas dos trabalhadores, tendo também o sentido de conquista de direitos sociais (Cohn, 1981, 1996; Donnangelo, 1975). Uma terceira interpretação corrente na literatura dos anos 70 e 80 , e que em grande medida incorpora as anteriores, é uma atualização brasileira da hipótese da convergência em sua vertente marxista-estrutural, internacionalmente utilizada na interpretação da origem das políticas sociais. Nessa perspectiva, a criação e o desenvolvimento da Previdência Social são parte de um processo de reatualização, pelo Estado, de condições necessárias à preservação e aos desdobramentos da ordem social capitalista que se explicita com base na análise das situações históricas consubstanciadas na Revolução de 30. Essas seriam apenas particularizações de processos em desenvolvimento no conjunto do sistema capitalista, como as crises econômicas e pressões sobre a estrutura de poder atribuíveis às classes sociais. As tensões geradas pelas contradições econômicas, fazendo pesar sobre os assalariados urbanos o efeito das crises periódicas da economia de exportação e levando à sua adesão o movimento político revolucionário, explicam o desenvolvimento do processo político-econômico do governo Vargas, tanto de incorporação dos assalariados ao processo político quanto de promoção da industrialização. Se do ponto de vista dos assalariados a política trabalhista então estabelecida, englobando a Previdência Social e a legislação que regulamentava as relações entre o trabalho e o capital, é uma resposta a reivindicações de consumo de mínimo de bens e serviços, do ponto de vista do Estado trata-se de criar condições para a preservação e expansão da ordem capitalista por meio da reorganização dos fatores básicos de produção: capital e trabalho (Donnangelo, 1975).
} 
O período Vargas que se inicia em 1930 marca um momento de reorganização das relações Estado/sociedade de forma corporativista, que teve como um de seus objetivos incorporar os trabalhadores urbanos ao jogo político, embora de forma subordinada ao Estado. Isso se deu pelo reconhecimento do trabalho organizado e de políticas sociais. Ao lado dos sindicatos e dos tribunais trabalhistas, a Previdência Social era uma instituição fundamental na estrutura legal montada para se apropriar do espaço de demanda e do espaço organizacional, definindo quem e como poderia representar o trabalho (Malloy, 1986; Menicucci, 1990).

No conceito consagrado de Santos (1979), estabeleceu-se no Brasil a 'cidadania regulada', que traduz a relação entre ocupação e cidadania, sendo reconhecidos determinados direitos sociais a setores de assalariados urbanos. Entre esses direitos, vai se inserindo o da assistência à saúde, mesmo que de forma secundária em relação às prestações previdenciárias propriamente ditas.

Entretanto, a expansão da cobertura previdenciária com a criação de vários IAPs não se traduziu em ampliação correspondente da assistência à saúde até os anos 60 . O contexto de criação dos IAPs foi caracterizado por um esforço de restrição de despesas por parte das instituições previdenciárias, sendo uma de suas manifestações a queda real dos gastos com assistência médica, que, entretanto, mais do que expressar a restrição de gastos, refletia uma mudança de enfoque em relação à responsabilidade da Previdência Social na prestação de cuidados médicos. Com a criação do Instituto de Aposentadorias e Pensões dos Industriários (IAPI), em 1938, deu-se uma inflexão na estrutura previdenciária, vindo à tona uma concepção de previdência social mais restrita quanto aos benefícios, fixados em bases atuariais, seguindo um modelo de capitalização de reservas pelo qual se relegava a assistência a um plano secundário. Esta passa a ser condicionada às disponibilidades das instituições previdenciárias - e foram ainda estabelecidos tetos máximos para as despesas com esses serviços (Oliveira \& Teixeira, 1986; Donnangelo, 1975; Cordeiro, 1984). Apenas no final dos anos 50 e, principalmente, no início da década de 60 é que ocorrerá uma substancial expansão da assistência médica previdenciária de 
forma a constituir um novo padrão de atenção à saúde no país, até então, em grande parte, de natureza privada (Braga \& Paula, 1981). ${ }^{24}$

No âmbito dos institutos, a extensão dos serviços médicos e assistenciais era, em parte, condicionada às pressões da massa segurada, que apresentavam variações de intensidade entre as categorias profissionais. Isso se refletia nas variações do gasto com assistência médica, que, por exemplo, em 1964 iam de 20,2\% do total de despesas no IAPI a 63,4\% no Instituto de Aposentadorias e Pensões dos Bancários (IAPB), o mais pródigo dos IAPs em razão da capacidade também maior de mobilização e pressão dos bancários. Essa categoria incluía de forma mais ativa a assistência médica entre suas reivindicações. Nas demais categorias, embora a questão estivesse presente, não era prioritária (Cordeiro, 1984). Outro fator, contudo secundário, que pressionou a expansão da assistência médica pelos institutos foi a ocorrência de grande número de afastamentos por invalidez, que onerava o sistema previdenciário com o pagamento de benefícios pecuniários e punha em risco o seu equilíbrio financeiro. A assistência médica funcionando como prevenção favorecia a diminuição de concessão desse tipo de benefício (Donnangelo, 1975).

Isso significa que, apesar de os programas de assistência médica terem se ampliado, não se desenvolveu uma política deliberada de assistência à saúde nos IAPs. Somente com a Lei Orgânica da Previdência Social (Lops), promulgada em 1960, que propunha a uniformização dos benefícios previdenciários, a assistência médica passou a ser assumida como parte inerente da Previdência Social, devendo ser assegurada a todos os seus beneficiários. Ao mesmo tempo, por intermédio da Lops, o governo legitimou uma prática que já vinha existindo, permitindo que empresas atendessem seus empregados e dependentes mediante serviços próprios ou contratados. Mas mesmo na Lops, a assistência permaneceu condicionada às disponibilidades financeiras, não se definindo uma fonte específica de financiamento, embora já nessa época se identificasse entre alguns setores técnicos da previdência a necessidade de uma

\footnotetext{
De acordo com a análise de Possas (1981), o crescimento das atividades dos IAPs no campo da medicina foi viabilizado pela expansão da indústria farmacêutica, que favoreceu a constituição de uma medicina de massa. No campo das idéias, a partir de 1945, com o advento das idéias beveridgeanas relativas a uma previdência ampla, assistencial e pública, as idéias de seguro social restrito foram parcialmente suplantadas.
} 
fonte de custeio para a saúde. Essa característica de nascer imbricada à previdência como um benefício secundário em relação às prestações previdenciárias vai ser outra das marcas da assistência à saúde ao longo de sua trajetória. Nem mesmo a Constituição de 1988 - que consagrou em termos formais a obrigação pública em relação à saúde - logrou resolver a questão do seu custeio por meio de fontes independentes da Previdência. Apenas muito recentemente, pela Emenda Constitucional 29/2000, foram definidas fontes específicas para financiamento da saúde, questão que será retomada mais à frente.

O caráter secundário da assistência médica, como política pública no âmbito previdenciário até os anos 50 , pode ser verificado pelas despesas com esses serviços em relação às despesas típicas do seguro social (aposentadorias e pensões), que constituíam a função básica da Previdência Social. Como mostram vários autores (Braga \& Paula, 1981; Possas, 1981; Oliveira \& Teixeira, 1986; Rezende da Silva \& Mahar, 1974), embora tenha ocorrido aumento dos gastos reais com assistência médica no período de 1923 a 1949, os coeficientes em relação à despesa e à receita totais são decrescentes, e até 1950 não se verificou nenhuma expansão significativa da assistência médica individual. É na década seguinte que se torna expressiva a amplitude do sistema previdenciário como política de atenção à saúde, paralelamente ao correspondente processo histórico de centralização institucional e política. Do ponto de vista institucional, o desenvolvimento da Previdência Social logo no início do governo militar inaugurado em 1964 significou a unificação de todos os institutos em uma única estrutura institucional, abrangendo toda a força de trabalho, com a criação, em 1966, do Instituto Nacional de Previdência Social (INPS), que estendeu o seguro social para todos os assalariados urbanos. Ao absorver número cada vez maior de assalariados como contribuintes compulsórios, a Previdência Social passou a mobilizar volume crescente de recursos e aumentou progressivamente a participação da assistência médica no conjunto das despesas. ${ }^{25}$

\footnotetext{
25 Se em 1949 o gasto com a assistência correspondia a 7,3\% da despesa total dos IAPs, em 1960 já era de 19,3\%, atingindo em 1972, já então no âmbito do INPS, 24,4\% dos gastos (Braga \& Paula, 1981). De 1965 a 1969, os gastos com assistência médica cresceram 158\%, ao passo que os com os benefícios previdenciários cresceram 70\% (Bacha, Matta \& Mondenesi, 1972, apud Braga \& Paula, 1981).
} 
Outro indicador da pouca relevância da assistência médica ou da ausência de uma política deliberada de assistência antes da década de 60 está no fato de que dos aproximadamente sete milhões de segurados que se incorporam ao INPS em 1967, por força da unificação dos IAPs, apenas cerca da metade contava com serviços médicos de forma regular. A outra metade provinha do instituto dos industriários, o IAPI, que apenas tardia e timidamente começava a incorporar a assistência médica entre seus benefícios, na medida em que era pouco pressionado por uma categoria ainda frágil politicamente, dado o desenvolvimento ainda incipiente da industrialização no Brasil. Entretanto, foi pioneiro de uma prática que se desenvolverá entre órgãos públicos: desde a década de 40, o IAPI destinava recursos de seu orçamento para garantir uma assistência diferenciada exclusivamente para seu quadro de funcionários.

\section{Expansão da Assistência à Saúde como Política Governamental}

Na década de 60, fica explicitada a disposição pública no sentido de tornar a assistência à saúde uma política governamental, situação que é evidenciada nos pronunciamentos, regulamentos, congressos e seminários do período, nos quais são constantes as temáticas da generalização e da institucionalização da atenção médica. ${ }^{26}$ Após a criação do INPS, já no governo militar, quando se concretizou a unificação previdenciária nos termos previstos na Lops, é que vai se constituir um consenso no sentido de que o Estado deveria estender os serviços de saúde a toda a população. Paralelamente à extensão da cobertura previdenciária, que na década de 80 passou a abranger a quase totalidade da população urbana e parte da rural, verifica-se um movimento de ampliação da cobertura da assistência médica.

Dois fatores justificam o aumento da prestação de serviços médicos e dos gastos correspondentes no âmbito do INPS: em primeiro lugar, as

\footnotetext{
Em estudo clássico das instituições médicas, Luz (1986) analisa as temáticas dominantes nos discursos institucionais do período $60 / 64$, nos quais essa disposição pública é evidenciada. De acordo com sua interpretação, a universalização da atenção médica não foi uma reivindicação das classes subalternas nas lutas operárias ou nos movimentos sociais mais amplos, sendo, antes, um projeto de hegemonia burguesa conduzido pelas instituições médicas.
} 
pressões pelo cuidado médico, em razão do processo de industrialização e urbanização, que colocou nas grandes cidades uma massa assalariada em más condições de trabalho e com baixa remuneração (Braga \& Paula, 1981; Cohn, 1996); em segundo, a tecnicização e a elevação dos custos dos atos médicos. A partir dos anos 50, ocorre, de forma generalizada, em diferentes países, uma elevação substancial dos custos com assistência médica, associada às transformações científicas e tecnológicas, que geraram mudanças no saber e na prática médica e levaram à maior utilização de medicamentos, serviços para diagnóstico e incorporação mais intensiva de equipamentos. Entre as conseqüências desse processo estão a diversificação de especialidades e da mão-de-obra empregada e a localização do hospital como ponto de encontro das diversas especialidades médicas como detentor da infra-estrutura e dos equipamentos

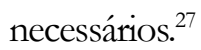

Também no Brasil a medicina previdenciária, que se expande a partir do final da década de 50, será essencialmente hospitalar e curativa. Expressão do progresso tecnológico, com elevação da eficiência e dos custos da atenção médica, é o crescimento das despesas hospitalares no âmbito da Previdência Social bastante superior às despesas ambulatoriais no período de 1960 a 1967, explicado pelas práticas médicas com maior utilização de tecnologia, relacionadas ao consumo dos produtos da indústria de equipamentos e aparatos médicos e à produção de medicamentos. ${ }^{28}$

A característica básica da política de saúde a partir dos anos 60 seria reconhecida como a ênfase na medicina previdenciária, de cunho individual e

$27 \mathrm{Na}$ linguagem da literatura dos anos 70 e 80, o cuidado médico deixa de ser 'artesanal' - por analogia com o desenvolvimento industrial - e assume características da grande indústria Nessas análises, as instituições médicas estariam submetidas aos mesmos processos que caracterizam o desenvolvimento capitalista e que envolvem mudanças na organização dos meios de produção e nas relações de trabalho, tais como: eliminação do modelo de produção artesanal, separação entre o produtor direto e os meios de produção, substituição da troca direta entre produtor/consumidor pela venda direta da força de trabalho (assalariamento), divisão do trabalho e concentração dos meios de produção. Acompanhando as transformações mais amplas da sociedade capitalista, a produção de serviços de saúde se integraria ao processo de produção e reprodução do capital.

28 Ao passo que o crescimento total das despesas com assistência médica no período de 1960 a 1967 variou de 9,1\%, em 1965, a 42,4\%, em 1967, o crescimento das despesas hospitalares no mesmo período variou entre 15,9\% ao ano, em 1963, e 117,6\%, em 1965, com uma exceção de crescimento negativo em 1962 a que correspondeu um crescimento das despesas ambulatoriais muito pequeno. Isso significa que nesse período o valor real gasto com assistência médica subiu 3,3 vezes, ao passo que o gasto hospitalar aumentou nove vezes e o ambulatorial apenas 2,1 vezes (Braga \& Paula, 1981). 
assistencialista, centrada no atendimento hospitalar. A contrapartida da expansão da assistência médica previdenciária foi a perda de importância relativa das medidas de saúde pública voltadas para o atendimento de necessidades coletivas e de caráter preventivo, situação que se expressa pelo orçamento precário e declinante do Ministério da Saúde, órgão responsável por essas ações, e pelo inexpressivo crescimento dos recursos financeiros nos primeiros anos da década de $70 .{ }^{29}$ A diminuição da importância político-institucional da saúde pública em relação à assistência à saúde a partir da década de 60 pode também ser constatada pela comparação entre os componentes do gasto público com saúde. Após 1967, observa-se a tendência de ampliação do gasto com assistência médica individual a cargo do INPS em relação ao gasto direto da União, dos estados e dos municípios com saúde e saneamento em proporção quase que inversa. ${ }^{30}$

Uma das conseqüências da elevação dos custos da assistência médica foi a inviabilização do acesso à medicina privada por parcelas significativas da população, ampliando a demanda por assistência pública. Com a expansão da estrutura hospitalar como o centro do modelo médico assistencial previdenciário, reduz-se violentamente a prática liberal da medicina nos grandes centros urbanos (Luz, 1986).

O caminho para a universalização de cobertura, apontado com a criação do INPS e a unificação de todos os institutos, com a correspondente eliminação

29 Ao passo que em 1968 a participação do orçamento do Ministério da Saúde no orçamento global da União era de 2,21\%, em 1972 já passa para 1,40\%, em 1973 para 0,91\%, atingindo apenas 0,90\% em 1974. Contrariando essa tendência, ocorre em 1975 um crescimento expressivo dos recursos do Ministério da Saúde da ordem de 35,7\% (Braga \& Paula, 1981), o que se explica pela proposta contida no II PND do governo Geisel de priorizar o setor saúde no campo social.

30 Em 1967, o gasto direto da União, dos estados e dos municípios com saúde (e saneamento) correspondia a 56\% do gasto estatal em saúde, ao passo que a participação do INPS, responsável pela assistência médica individual, era aproximadamente de $44 \%$, sendo a relação gasto direto/ gasto INPS da ordem de 1,27\%. Em 1972, o gasto com saúde coletiva se reduz a 45,1\% do gasto total com saúde, sendo que, em contrapartida, as despesas assistenciais atingem $51,7 \%$, nada menos do que $77 \%$ do gasto direto (Braga \& Paula, 1981). De acordo com Bacha, Matta e Mondanesi (1972), o maior gasto com assistência médica se justifica pelo fato de ela ser custeada pela Previdência Social, que, arrecadando mais, tinha também mais recursos. As ações de saúde coletiva, por sua vez, pela indivisibilidade de seu consumo, não poderiam ser custeadas pelas contribuições previdenciárias de caráter securitário. Essa opinião é contestada por Braga e Paula (1981), para quem a política adotada foi uma opção determinada por interesses que se cristalizavam politicamente no Estado. Para Luz (1986), a explicação para o modelo de estrutura das instituições médicas estabelecido envolve também um fator ideológico, entendendo-se por isso a preferência pelo modelo da medicina assistencial ao da saúde pública como resultado da estruturação simbólica de representações de saúde e doença constituídas em razão da medicalização da vida social. 
das diferenciações entre eles, significou a implosão do arranjo corporativo que caracterizara o início da Previdência Social - o que só foi possível no governo militar, quando as bases do poder autoritário passaram a prescindir do apoio dos trabalhadores. Portanto, não foi o resultado de um movimento dos assalariados em torno da igualdade, os quais, em muitos casos, viram na unificação a perda de benefícios corporativos e se posicionaram contra ela. Isso teve o efeito de retardá-la até o regime autoritário, que excluiu os trabalhadores do jogo político. A universalização da assistência à saúde não se constituira como uma demanda prioritária dos trabalhadores organizados, que tinham como objeto fundamental de reivindicação no período da democracia populista (1946/64) o controle da Previdência Social (Cohn, 1996; Luz, 1986). De fato, os IAPs institucionalizaram a segmentação corporativa por meio da ação discriminatória do Estado que, ao mesmo tempo que excluía da cobertura previdenciária aqueles cujo trabalho a lei desconhecia, garantia benefícios diferenciados no âmbito de cada instituto (Vianna, 1998). A competição entre categorias profissionais, induzida pelo formato institucional da Previdência Social, não favoreceu uma atuação reivindicatória mais geral.

Isso significa que a trilha da universalização institucional da assistência não teve como apoiadores os principais afetados por ela: os empregados urbanos assalariados. Não tardaria que novas formas de segmentação dos trabalhadores se recriassem na prestação de serviços de saúde, dificultando a constituição de uma visão universalista por parte dos assalariados e reforçando sua visão corporativa, favorecida pelos arranjos anteriores. A forma como se dará a expansão da assistência pública definirá os contornos institucionais da assistência à saúde no Brasil e refletirá essa configuração político-institucional anterior.

\section{Expansão da Assistência a partir da Compra de Serviços Privados: constituição de atores e interesses}

O fato de a Previdência Social assumir a assistência médica como uma de suas atribuições não implicou necessariamente a instalação de uma infra-estrutura própria de produção de serviços de saúde. Com a unificação dos institutos, 
a existência de grande demanda reprimida, particularmente dos segurados originados de institutos menos pródigos, gerou uma pressão muito grande sobre as unidades de saúde incorporadas pelo INPS, sem condições de ser atendida de imediato na rede própria previdenciária.

Enquanto vigorava o sistema de uma caixa para cada empresa, não se organizavam serviços médicos próprios, e a caixa financiava o tratamento de seus associados pelos médicos que os assistiam. Algumas caixas viriam a se destacar, em razão da maior disponibilidade de recursos, e montaram seus próprios ambulatórios. ${ }^{31}$ Para os IAPs, de âmbito nacional e com maior número de segurados, tornou-se viável financeiramente a organização de serviços médicos próprios, opção que não foi, contudo, da maioria, especialmente no caso da assistência hospitalar. Alguns se empenharam em operar hospitais próprios, como o Instituto de Aposentadorias e Pensões dos Trabalhadores do Comércio (Iapetec) e o Instituto dos Ferroviários e Empregados em Serviços Públicos (Iapfesp), o instituto dos funcionários públicos e o dos marítimos. O instituto dos bancários, embora fosse o mais rico, optou pelo credenciamento de hospitais particulares. O instituto dos comerciários também priorizou a compra de serviços. Embora fosse o maior, operou apenas com três hospitais próprios, mesmo número do instituto dos marítimos, que era o menor deles. Ao que parece, os hospitais dos institutos eram considerados de boa qualidade pelos seus usuários, o mesmo não acontecendo com outras unidades públicas ou filantrópicas, rejeitadas pelos trabalhadores. ${ }^{32}$

A legislação dos institutos não definia a instalação de infra-estrutura própria de produção, sendo permitidos convênios e contratos com outros institutos e caixas ou com estabelecimentos hospitalares privados. Na inexistência de uma política de ampliação dos serviços próprios, era impossível o atendimento imediato da demanda por meio da produção direta, dada a precariedade

\footnotetext{
31 "Isto ocorreu com ferroviários, bancários e empregados de companhias que exploravam serviços de utilidade pública (luz, gás e telefones). Nestes casos, ou com recursos da própria caixa, ou com auxílio da empresa interessada em melhorar a assistência, algumas caixas puderam montar ambulatórios e contratar pessoal, inclusive médicos" (Bastos, 1979: 99).

32 De acordo com um assessor do Ministério da Previdência e Assistência Social (MPAS), em palestra realizada em 1976, os trabalhadores, mesmo "na assistência médica, só admitiam como alternativa para os serviços de seu Instituto os da medicina liberal e privada. Em nenhuma hipótese aceitavam os serviços de santas casas, de hospitais públicos ou dos de ensino. Estes eram considerados serviços para indigentes, e a desumanização da assistência médica sua indesejável característica" (Bastos, 1979: 99-100).
} 
da rede pública (Donnangelo, 1975). Principalmente no caso do atendimento hospitalar, a expansão da assistência médica pública, por meio da compra de serviços, recorreu, em parte, à rede de atendimento de natureza privada, que se desenvolvia independentemente do setor público. ${ }^{33}$

Entretanto, até 1964 a compra de serviços médicos era ainda minoritária e preponderante apenas no caso do IAPI - instituto caracterizado por uma inclinação acentuadamente privatista de sua tecnoburocracia, que exerceu grande influência no desenvolvimento da previdência social brasileira, no interior do qual surgiu a proposta de 'privatização' da assistência médica (Luz, 1986). A rede de serviços próprios dos IAPs em 1964 era significativa para o atendimento de sua clientela, dada a reduzida cobertura previdenciária antes da criação do INPS. ${ }^{34}$ É possível inferir que até a década de 60 o desenvolvimento da rede privada hospitalar seguia um movimento próprio, com o crescimento, em parte, independente da política pública assistencial. Além disso, no período de 1935/50 há um crescimento relativo dos leitos hospitalares públicos em comparação aos privados. Após essa época é que vai se observar o crescimento progressivo da proporção de hospitais privados em detrimento dos públicos, além da expansão das clínicas privadas destinadas ao atendimento ambulatorial. A partir dos anos 70, haverá uma verdadeira estagnação na capacidade relativa da rede hospitalar pública (medida pelo número de leitos), que se manterá praticamente inalterada até a década de 90, o que terá como contrapartida o crescimento da importância da rede hospitalar privada, como pode ser visto na Tabela 1.

Esses dados sugerem que foi a partir da criação do INPS, em 1966, na vigência do regime autoritário, que a política previdenciária de assistência à saúde passou a dar prioridade à contratação de serviços de terceiros em detri-

\footnotetext{
Desde 1945, pelo menos, para quando dados mais seguros são disponíveis, o número de leitos da rede hospitalar privada era superior ao da rede pública, e esta superioridade vai se tornando mais pronunciada gradativamente de tal forma que, em 1950, 53,9\% dos leitos eram de propriedade particular e, em 1960, já correspondiam a $62,1 \%$, dos quais $14,4 \%$ tinham finalidade lucrativa (Braga \& Paula, 1981).

34 Essa rede em 1964 incluía 22 hospitais em atividade e cinco em construção, 505 ambulatórios e 28 consultórios médicos, com a estimativa de atendimento a $22 \%$ da população brasileira (Oliveira \& Teixeira, 1986). Apesar da imprecisão das informações do período, relacionando esses dados com outros apresentados por Braga e Paula é possível inferir que a extensão da rede pública era significativa, uma vez que, para uma cobertura estimada de $22 \%$ da população, detinha $37 \%$ dos leitos hospitalares disponíveis no país.
} 
mento da ampliação dos serviços próprios. Essa opção se fez em nome de uma racionalidade viabilizadora da expansão da cobertura e sob o argumento da crise financeira dos IAPs e da necessidade de novas formas de regulação das instituições e da prestação de serviços (Oliveira \& Teixeira, 1986)..$^{35}$ Após 1968, vai prevalecer uma nova racionalidade na saúde acompanhada da exclusão de discursos alternativos, sendo um dos seus traços a concentração de poder decisório em altos escalões da hierarquia burocrática institucional, que tinha no discurso do planejamento a prática institucional dominante (Luz, 1986). Além disso, com a unificação da assistência médica no INPS, tornam-se dominantes as forças institucionais liberais e privatistas da corporação médica, portadoras de um discurso medicalizante como solução para os problemas de saúde, cuja materialização será a implantação da prática assistencial curativa de acentuada tendência privatizante, sob a forma de convênios entre a iniciativa privada e o Estado. ${ }^{36}$

35 Braga e Paula (1981) constatam o crescimento da prestação de assistência médica concomitantemente a uma crise financeira do sistema previdenciário, para a qual identificam várias razões: do lado da receita, o não-recolhimento por parte da União e das empresas empregadoras das contribuições efetivamente devidas; e, do lado das despesas, os reajustamentos, abonos, majorações nos benefícios e auxílios, elevadas despesas administrativas etc. Acrescentam a isso a deficiência do rendimento patrimonial e imobiliário, de tal forma que, no caso da saúde, o sistema, não tendo bases financeiras sólidas, era incapaz de atender à crescente pressão da massa assalariada urbana. Institucionalmente, esbarrava ainda na diferenciação entre os institutos. A criação do INPS será então uma transformação institucional que ampliará a escala econômica das operações, aumentará os recursos financeiros por meio do aumento da contribuição e expansão da cobertura e possibilitará aumento do grau de controle pelo Estado. Segundo os autores, nos anos 60 já se identificava a necessidade de fonte de custeio específica para a assistência médica e a necessidade de articulação dos serviços médicos previdenciários.

36 Por medicalização, entende-se a tendência de suprir as carências de saúde da população com cuidados médicos com a medicalização da vida social, ou seja, a impregnação da sociedade pelas instituições médicas. 
Tabela 1 - Leitos hospitalares. Brasil, 1935-1999

\begin{tabular}{c|c|c|c|c|c|c|c}
\hline Anos & \multicolumn{3}{|c|}{ Leitos hospitalares } & Anos & \multicolumn{3}{c}{ Leitos hospitalares } \\
\hline & Públicos \% & Privados \% & Total & & Públicos \% & Privados \% & Total \\
\hline 1935 & 36,69 & 63,31 & 61.877 & 1981 & 23,9 & 76,1 & 522.769 \\
1945 & 44,60 & 55,40 & 124.339 & 1982 & 24,0 & 76,0 & 530.501 \\
1950 & 46,13 & 53,87 & 162.515 & 1983 & 23,9 & 76,1 & 534.055 \\
1960 & 37,89 & 62,11 & 257.371 & 1984 & 23,7 & 76,3 & 538.721 \\
1965 & 36,97 & 63,03 & 228.545 & 1985 & 25,8 & 74,2 & 532.283 \\
1971 & 33,90 & 66,10 & 367.522 & 1986 & 22,4 & 77,6 & 512.346 \\
1975 & 31,60 & 68,40 & 394.782 & 1987 & 22,3 & 77,7 & 519.698 \\
1976 & 26,80 & 73,20 & 443.888 & 1988 & 22,9 & 77,1 & 527.196 \\
1977 & 26,60 & 73,40 & 455.712 & 1989 & 22,9 & 77,1 & 522.895 \\
1978 & 26,20 & 73,80 & 475.452 & 1990 & 23,4 & 76,6 & 533.558 \\
1979 & 24,30 & 75,70 & 488.323 & 1992 & 24,8 & 75,2 & 544.357 \\
1980 & 24,10 & 75,90 & 509.168 & 1999 & 29,6 & 70,4 & 484.945 \\
\hline
\end{tabular}

Fontes: 1935 - Bahia (1991: 20); 1935-75 - Braga e Paula (1981: 75).

1976-99 - Estatísticas da Saúde - Assistência Médico-Sanitária (AMS - IBGE).

Notas: à exceção da AMS, esta tabela utiliza dados obtidos de diversas fontes, com graus

distintos de fidedignidade, devendo ser avaliada apenas como indicadora de tendência.

Para os anos de 1945-75, as porcentagens e os totais foram corrigidos em relação à tabela original.

Será, assim, somente com a ampliação da demanda após a unificação dos institutos e com a expansão da cobertura previdenciária, associada a uma opção pela compra de serviços, que o setor privado irá se fortalecer ao se tornar o mecanismo pelo qual se garantirá a ampliação da cobertura assistencial pública. Ao não se optar pela expansão da rede própria, a política governamental irá favorecer a expansão da rede privada, escolha que será condicionante da evolução da assistência médica posterior.

A opção pela compra de serviços privados encontra explicação no contexto político pós-64, fazendo parte de um modelo mais geral de relacionamento entre Estado e sociedade e de uma política de centralização e privilegiação do produtor privado. As Cartas Constitucionais do período do regime militar dão prioridade à iniciativa privada no processo produtivo, em detrimento do setor público. A reforma administrativa efetivada pelo decreto-lei 200/67 traduz a filosofia do governo de eximir os órgãos da administração pública da prestação direta de serviços sempre que a iniciativa privada pudesse assegurar sua execução, definindo para cada ministério o máximo possível de abandono das ações executivas em benefício do setor privado, com restrição das suas 
atividades, na medida do possível, ao nível normativo. ${ }^{37}$ No caso da prestação da assistência médica, o decreto-lei 200 dava preferência à celebração de convênios com entidades públicas e privadas já existentes na comunidade. O resultado foi a vinculação crescente da atividade privada às instituições estatais, quando o Estado assumiu o papel de regulador (Oliveira \& Teixeira, 1986; Possas, 1981).

Como assinala Luz (1986), a atenção médica se 'estatiza' paulatinamente, no sentido de que reduz de forma radical a prática da medicina liberal e submete a atividade médica à Previdência Social. O Estado, como organizador dos serviços de saúde, se 'privatiza' progressivamente por intermédio dos hospitais e clínicas credenciados. ${ }^{38} \mathrm{O}$ INPS tornou-se o grande comprador de serviços médicos e passou a sustentar uma procura ampliada por meio da Previdência Social, garantindo um mercado institucional pela via dos segurados da Previdência. É nesse sentido que a interferência estatal contribuiu para o fortalecimento do setor privado, uma vez que dificilmente a expansão e a manutenção da rede privada seriam viáveis de forma independente do Estado, tendo em vista os baixos níveis salariais da população e o aumento dos custos da assistência médica, fatores que inviabilizariam à maioria da população brasileira a compra direta de serviços médicos.

Pela manipulação de recursos, a intervenção estatal estimulou a expansão de uma rede privada de produção de serviços e estancou o crescimento da rede pública. Em conseqüência, favoreceu uma determinada trajetória da política

37 Como mostra Cardoso (1979: 51), o governo que se instala em 1964 "procurou legitimar-se como restaurador da economia e como um movimento favorável à definição de um padrão de desenvolvimento baseado na livre empresa, contra o estatismo econômico que se atribuía ao governo deposto".

38 Em 1960, 50\% das atividades médicas estavam no âmbito previdenciário; em 1967, dos 2.800 hospitais do país, 2.300 estavam contratados pelo INPS e, em 1973, 90\% dos serviços médicos estavam direta ou indiretamente dependentes do INPS (Donnangelo, 1975; Oliveira \& Teixeira, 1986). Em 1977, cerca de 66\% dos hospitais e aproximadamente 50\% dos leitos hospitalares privados do país encontravam-se à disposição da Previdência Social (Fessel, 1977, apud Possas, 1981). Além da assistência médica previdenciária, estados e municípios prestavam algum tipo de assistência, embora bastante inferior em quantidade e qualidade. Dados de 1969 mostram que, para o conjunto do país, os gastos com assistência médica dos estados correspondiam a menos de $25 \%$ do gasto total, ao passo que os do INPS equivaliam a cerca de $75 \%$. Embora houvesse grande variação dos gastos entre os estados, apenas em seis deles o gasto com saúde ultrapassava a proporção verificada para o conjunto do país: Pará, Maranhão, Piauí, Alagoas, Guanabara e São Paulo. A assistência pública relevante cabia ao INPS (Rezende da Silva \& Mahar, 1974). 
de assistência à saúde, ao mesmo tempo que engendrou interesses em torno da manutenção ou ampliação dos incentivos públicos ao setor privado. ${ }^{39}$

A expansão da medicina capitalista por meio, principalmente, da transferência de recursos da Previdência Social foi mais significativa em relação aos serviços hospitalares, pois no caso dos serviços ambulatoriais os IAPs já tinham previamente organizado serviços próprios, principalmente para o controle da prestação de benefícios previdenciários básicos, como o seguro-doença e o

Essa interpretação difere, embora não lhes seja totalmente oposta, das interpretações correntes na literatura de tendência estrutural e economicista que caracteriza a maior parte da produção teórica setorial nos anos 70 e 80 . Nesta, a solução adotada na política de saúde assistencial fez prevalecer os interesses capitalistas, seja no sentido mais estrutural de manutenção da ordem capitalista, ordenando as relações capital/trabalho, seja no sentido de atender aos interesses e pressões dos setores empresariais, em uma perspectiva sociocêntrica para a explicação das políticas sociais. O crescimento da assistência médica previdenciária é visto como resultado de uma associação entre Estado, empresários nacionais (empresas prestadoras de serviços médicos) e indústria estrangeira (indústria farmacêutica e de equipamentos e aparatos médicos), que propiciou a criação de um 'complexo médico-industrial', responsável por elevadas taxas de acumulação de capital de grandes empresas monopolistas internacionais (Oliveira \& Teixeira, 1986; Cordeiro, 1984). Essa análise reproduz no âmbito da política de assistência à saúde as explicações consagradas relativas ao padrão de desenvolvimento econômico brasileiro após a instalação do regime militar em 1964, ou seja, o desenvolvimento baseado no tripé Estado/empresas estrangeiras e grandes empresas nacionais (Cardoso, 1979). Nessa perspectiva, a explicação do desenho institucional estabelecido para a prestação de assistência médica passa pelas relações entre política de saúde e política econômica, vinculando-se ao modo de desenvolvimento do capitalismo no Brasil, estando a política de saúde voltada para abrigar os interesses capitalistas do setor. Se a expansão da assistência previdenciária revela a existência de uma demanda insatisfeita e elástica, demonstra "também uma ativa acumulação de capital na rede privada de assistência médica, cujas taxas de lucro e de investimento requeriam respaldo estatal, via elevação dos dispêndios do INPS” (Braga \& Paula, 1981: 101). Ao mesmo tempo que se expande a rede hospitalar privada, observam-se o avanço da indústria farmacêutica e a expansão das importações brasileiras de equipamentos médicos. Braga e Paula consideram que a constituição prévia de interesses empresariais na área médica, particularmente hospitalar, garantiu que fossem capazes de 'moldar' parte fundamental da política de saúde, de forma que o Estado sustentou a acumulação de capital pelo setor prestador de serviços e pela indústria farmacêutica e de equipamentos médicos. Nessa linha, também Luz (1986) considera as clínicas e os hospitais privados como o 'necessário pendant institucional' das indústrias farmacêuticas e de equipamentos médicos como interesses institucionais que constituem o Estado. No tripé da saúde, o Estado funcionaria como um intermediário entre as indústrias multinacionais de saúde e as indústrias nacionais de produção de serviços, subsidiando ambas por meio da atenção médica da Previdência. As modalidades de participação do Estado na assistência médica por intermédio da Previdência Social reafirmariam um padrão geral de ampliação dos direitos sociais, caracterizado como uma acomodação entre as pressões dos assalariados pela garantia de consumo e os interesses dos produtores privados de serviços (Donnangelo, 1975). Em uma variante dessa perspectiva estrutural, Possas (1981) discorda da idéia de que as instituições médicas sejam apenas o local da acumulação capitalista no setor saúde, gerando pressões no sentido de transferir recursos do setor público para o privado, e considera que a expansão e as características da política assistencial atendem, principalmente, às demandas geradas pelo sistema produtivo e se vinculam à necessidade de ordenação das relações entre capital e trabalho. A política assistencial previdenciária se caracterizará por ser uma medicina voltada para a força de trabalho, cuja reprodução é entendida à luz da reprodução do capital e que terá a crescente participação do Estado, além de ter a 'função' de recuperar o trabalhador para mantê-lo em condições de produtividade. E o atendimento dessas necessidades se dará também por meio de uma produção capitalista dos serviços de saúde. 
seguro-invalidez, cuja concessão é condicionada a algum atendimento médico. A rede hospitalar privada encontrou nessa política uma oportunidade de expansão, mesmo que à custa de certo esvaziamento da sua autonomia. Na condição de comprador, o Estado assumiu o papel de regulador de preços, de forma que o setor privado não operava livremente no mercado. Conseqüentemente, o Estado teve um papel fundamental na organização da assistência médica mediante o controle da instituição previdenciária e da relação que estabeleceu com o setor privado (Oliveira \& Teixeira, 1985; Possas, 1981). Apesar de essa política contribuir para a sua expansão, o setor privado mostrava resistências diante de sua subordinação crescente ao Estado, que lhe parecia uma 'estatização' da medicina, particularmente no aspecto do controle de preços dos serviços médicos pelo governo.

É claro que essa opção governamental não se faz em um cenário vazio, mas povoado de atores e interesses setoriais com capacidade diferenciada de pressão. As modificações no processo decisório e no jogo de pressões no interior da previdência implicaram a substituição do clientelismo populista anterior por uma aparente gestão previdenciária tecnocrática, supostamente imune a pressões, mas de fato aberta a interesses empresariais do setor saúde (Oliveira \& Teixeira, 1986). Com a implosão do arranjo institucional corporativista, após a unificação dos IAPs diminui a influência dos segurados, mas crescem a influência e a pressão de interesses ligados às instituições médicas sobre os órgãos de direção das instituições previdenciárias. As análises do período mostram evidências sólidas de que a expansão da assistência médica no âmbito da Previdência Social, com a opção pela compra de serviços de prestadores privados, reflete também a pressão de uma parcela mais organizada da corporação médica ligada aos interesses capitalistas no setor saúde - empresas médicas e hospitais -, uma vez que a expansão da rede hospitalar privadolucrativa criara fortes interesses econômicos já antes da reforma previdenciária. A privilegiação do setor privado pela política de assistência à saúde faz convergir para o Estado pressões crescentes no sentido de ampliar a esfera de atuação privada por meio do financiamento público da produção privada de serviços. ${ }^{40}$

\footnotetext{
40 Donnangelo (1975) identifica outras pressões internas no sentido de racionalização do setor, existindo no interior da instituição previdenciária técnicos que defendiam a ampliação do controle institucional sobre a produção para o controle de custos e da extensão da rede de serviços próprios. Entretanto, essa alternativa não foi vitoriosa no sentido de se configurar como a escolha governamental.
} 
Essas pressões refletiam os interesses dos três atores principais que constituíam a arena política da assistência médica nos anos 60: os proprietários de hospitais e clínicas credenciados pelo INPS ou aspirantes a credenciamento; os empresários das grandes companhias, interessados em ampliar a assistência à saúde de seus empregados de forma direta ou subsidiada pelo Poder Público; e os proprietários das empresas de medicina de grupo, empresas voltadas para prestação de serviços médicos para outras empresas, que irão se desenvolver também em decorrência de opções governamentais, conforme será visto adiante. A organização desses interesses se expressa na criação de seus órgãos de representação, concomitantemente à expansão da assistência médica previdenciária: em 1966, são criadas a Federação Brasileira dos Hospitais Credenciados pela Previdência Social, que se transformaria posteriormente na Federação Brasileira dos Hospitais (FBH), e a Associação Brasileira de Medicina de Grupo (Abramge). Embora existindo desde 1951, a presença política da Associação Médica Brasileira (AMB) cresce apenas a partir de 1964, quando assume posição contrária à intervenção ampliada do Estado na assistência médica. Nesse ponto, seus interesses vão se juntar aos da FBH e, conjuntamente, irão pressionar o governo no sentido de favorecer seus interesses nas políticas de saúde (Luz, 1986), que se traduziam na pressão pela ampliação da compra de serviços com o mínimo de interferência do Poder Público.

Se é verdade que a medicina privada preexistia à intervenção do Estado, as evidências ressaltam o crescimento do setor médico empresarial após a expansão da assistência médica previdenciária, com a privilegiação da compra de serviços. Isso significa que, além de ser responsável pelo crescimento do setor privado, a política definida vai condicionar a formação dos interesses dos atores privados prestadores de serviços de saúde, cujos objetivos, em grande parte, vão ser configurados após sua inserção na política de saúde. Expressão disso é a constituição de novos atores coletivos, em decorrência das formas de intervenção governamental, que estimularam o surgimento de instituições, como a medicina de grupo, e de organizações para defesa dos interesses constituídos em virtude da política de saúde. Ao serem incorporados à Previdência Social, os setores empresariais voltados para a assistência à saúde sofreram alterações em suas atividades e, conseqüentemente, passaram a 
redirecionar suas estratégias políticas no sentido da constituição e/ou preservação de regras que lhe fossem favoráveis.

A forma de expressão desses interesses e as estratégias políticas eram definidas com base nas regras vigentes no período, de acordo com as quais o Poder Executivo assumia o papel preponderante e, em razão das características da política de assistência à saúde, tinha na burocracia previdenciária o locus decisório. Se é possível considerar que o papel protagonístico do Executivo constitui um traço forte da atuação do Estado brasileiro, particularmente no período desenvolvimentista, tal Poder foi a arena central para a qual tendia a convergir o fluxo das relações provenientes da sociedade (Boschi \& Lima, 2002). A participação dos representantes dos interesses privados na saúde se fazia sentir de forma acentuada na esfera pública, sendo que a pressão desses grupos se exercia diretamente perante os ministros (via formal) e, ainda, pela localização de seus representantes em postos-chave da administração previdenciária e outros cargos responsáveis pela política de saúde no país. Essa atuação, que exemplifica a participação de certos setores da sociedade no processo decisório, mesmo em um contexto de Executivo muito fortalecido, configurava uma das formas de articulação de interesses entre a burocracia pública e a privada que prevaleceu durante o regime militar e ficou conhecida pela expressão de 'anéis burocráticos' (Cardoso, 1979). Mediante esse mecanismo, inseriam-se os interesses privados no aparelho estatal, fundindo-se os interesses privados e públicos.

\section{A Institucionalização da Assistência Médica Pública por Meio da Articulação com o Setor Privado: a constituição do 'complexo previdenciário'}

Essa política de assistência à saúde, baseada na privilegiação do setor privado para a prestação dos serviços para uma clientela crescente, em razão da gradativa ampliação de cobertura, levou à constituição, na década de 60 , do 'complexo previdenciário', entendido como o “conjunto de atividades médico-assistenciais desenvolvidas pelo sistema próprio e pelo sistema contratado da Previdência Social" (Possas, 1981: 247). 
Essa estrutura vai ser composta de subsistemas diferenciados, que se distinguem pela natureza jurídica e pela forma de articulação entre o setor público e o privado, apresentando lógicas diferenciadas de prestação de serviços: o sistema próprio, o contratado e o conveniado. Com a reforma institucional da previdência pós-64, foram aprofundados mecanismos já vigentes nos IAPs e, ainda, introduzidos novos dispositivos nas relações com o setor privado que iriam permitir sua reorganização em moldes mais empresariais.

A dinâmica da assistência médica no âmbito da Previdência Social na forma institucional do INPS e tendo como resultado o 'complexo previdenciário’ vai expressar as regras institucionais definidas e se traduzirá na constituição de diferentes interesses públicos e privados. Esses vão definir o campo de disputas que caracterizarão a arena política da saúde definida com base nas políticas previdenciárias para a assistência. Essas disputas vão se traduzir também em idéias diferenciadas, muitas vezes de caráter polarizado, expressando concepções sobre a saúde e a forma de expandir a assistência. Essas divergências estarão presentes em toda a trajetória da assistência e, grosso modo, identificam-se como concepções privatistas ou publicistas sobre a assistência médica. Objetivamente, vão se expressar no âmbito dos diferentes componentes institucionais da assistência médica previdenciária.

O primeiro subsistema do ‘complexo previdenciário’ era o sistema próprio, constituído pelos postos de assistência médica e hospitais do INPS e, a partir de 1977, do Instituto Nacional de Assistência Médica da Previdência Social (Inamps). ${ }^{41}$ Os primeiros eram responsáveis pela assistência ambulatorial, que, no âmbito dos IAPs, era predominantemente pública, situação que permanece após a reforma - na década de 70, cerca de 70\% dos estabelecimentos de saúde sem internação, responsáveis pelos atendimentos ambulatoriais, faziam parte da rede pública (AMS/IBGE). Entretanto, embora bem menos numerosos (menos de 20\% do total), os hospitais da rede pública caracterizavam-se por serem hospitais maiores e mais bem equipados, os quais, por sua

42 Em 1977 a Previdência Social passa por uma reestruturação institucional, com a criação do Sistema Nacional de Previdência e Assistência Social (Sinpas), que expressa a importância que a assistência adquirira ao ser separada a parte de benefícios da assistência médica, que passa a ser responsabilidade de outro órgão, o Instituto Nacional de Assistência Médica da Previdência Social (Inamps), ficando o antigo INPS responsável apenas pelos benefícios previdenciários pecuniários. 
superioridade técnica, assumiam os tratamentos mais graves, duradouros e caros. Daí que, em geral, tinham um custo operacional mais alto. ${ }^{42}$

O segundo subsistema do ‘complexo previdenciário' era constituído pelo sistema contratado, formado pela rede de serviços privados. Sob alegação da insuficiência da rede própria para atender à demanda crescente de segurados, estabelecimentos eram credenciados pelo INPS para atender pacientes segurados. Os serviços credenciados, particularmente de casas de saúde e hospitais, que correspondiam a mais de $80 \%$ dos estabelecimentos, eram remunerados na base de Unidades de Serviço (US), tabela de preços por ato médico que define o montante de US por tratamento, cujos valores variavam segundo a complexidade e a densidade tecnológica do ato médico, sendo o pagamento realizado pelo número de serviços. Essa forma de pagamento revelou-se um fator incontrolável de corrupção e de estímulo à produção de serviços hospitalares como forma de ampliar o faturamento, por meio da multiplicação e do desdobramento de atos médicos e da preferência por intervenções mais caras. ${ }^{43}$ Em razão da dificuldade de controle das contas hospitalares, a forma de pagamento por US, aliada ao superfaturamento, foi um fator que colocou em risco o sistema financeiro da Previdência e apontou para a inviabilidade de preservação desse modelo, levando a modificações posteriores, apesar da defesa intransigente da US pelos prestadores privados de serviços, seus principais beneficiários.

42 A série histórica da AMS/IBGE mostra que a proporção de estabelecimentos públicos de maior porte (mais de 150 leitos) era muito maior do que de estabelecimentos privados na década de 70 (19,69\% dos estabelecimentos públicos e 12,32\% dos privados, em 1976). No período de 1976-80, a relação de leitos por estabelecimento de saúde era superior a cem nos estabelecimentos públicos, ao passo que nos privados não atingia oitenta leitos. Essa diferença tende a diminuir a partir da década de 80, e na segunda metade da década os estabelecimentos privados vão apresentar uma proporção muito maior de hospitais de maior porte, apesar de os públicos do mesmo porte também apontarem crescimento. A segunda metade dos anos 80 foi, como será visto no próximo capítulo, o momento de maior explosão da assistência privada, o que se expressa no volume de leitos privados colocados à disposição de um mercado em expansão.

43 Um exemplo das distorções atribuídas à forma de pagamento por US, muito comentado pela literatura, é o fato de o parto cirúrgico ter sido mais bem contemplado na tabela de honorários, o que teria aumentado o coeficiente de cesarianas na rede privada contratada (Possas, 1981). As exceções ao pagamento por meio de Unidades de Serviço eram para as internações em tisiologia e psiquiatria, feitas mediante contrato global, em que o pagamento era feito por diária, que inclui todos os procedimentos realizados. Nesses casos, a lógica do prestador de serviços, de uma perspectiva estritamente mercantil, é a busca de redução dos custos com a realização de um mínimo de intervenções por paciente. 
A privilegiação da contratação de serviços privados expressava-se não apenas nas dimensões da rede hospitalar, mas no perfil das internações e nos gastos com a assistência. A maior parte das internações realizadas no país era financiada pela Previdência Social, a maioria delas (mais de 90\% durante toda a década de 70) sendo comprada aos hospitais privados (Oliveira \& Teixeira, 1986). Apenas cerca de $16 \%$ do total de internações realizadas na segunda metade da década de 70 eram feitas em hospitais públicos (AMS/IBGE) ${ }^{44}$ Progressivamente, os serviços hospitalares comprados de terceiros vão representando a quase totalidade dos gastos com assistência médica previdenciária, representando, em média, cerca de $90 \%$ da despesa geral do INPS no período de 1969 a 1975. No mesmo período, verificou-se o crescimento da contratação de consultas ambulatoriais e dos serviços de complementação diagnóstica, justificado pela incorporação de alta tecnologia à assistência ambulatorial que passa a se articular ao hospital, tornando-se o hospital a grande porta de entrada do sistema de assistência à saúde. ${ }^{45}$ No final da década de 70 , o setor privado já realizava mais de $50 \%$ das consultas ambulatoriais, embora a rede ambulatorial fosse predominantemente própria (Braga \& Paula, 1981; Oliveira \& Teixeira, 1986). A contrapartida era o lento crescimento dos serviços próprios. ${ }^{46}$

Do setor privado dependia, assim, a assistência médico-hospitalar prestada pelo INPS. Um instrumento importante para concretizar essa política foi o financiamento público a hospitais privados por intermédio do Fundo de Apoio ao Desenvolvimento Social (FAS), criado pela lei 6.168, de 9/12/74, para

44 A participação do setor privado nas internações financiadas pelo setor público será declinante, embora mantendo-se bastante elevada, a partir dos anos 80 , reduzindo-se para $80,3 \%$ das internações em 1987, mesmo ano em que pela primeira vez o gasto do Inamps com a rede privada foi inferior a 50\% das suas despesas totais (Médici, 1990). Essa situação decorre de alterações na política na década de 80 .

45 A constituição do hospital como porta de entrada contraria a lógica ideal pensada para os sistemas de saúde que, do ponto de vista da racionalidade técnica e financeira, pressupõe que eles devam ser organizados de forma hierarquizada e piramidal, em que na base do sistema são realizados os procedimentos de menor complexidade tecnológica e para uma cobertura mais ampla. Nos níveis seguintes, ao aumento da complexidade corresponde uma diminuição da cobertura, uma vez que diminui a necessidade de realização dos procedimentos previstos nos níveis hierarquicamente superiores do sistema de saúde. Assim, a porta de entrada ao sistema deve ser na base da pirâmide, o que se denomina nível da atenção primária: de menor custo, para todos e com alta capacidade de resolubilidade para a maioria das necessidades de atenção à saúde.

46 Dependendo da fonte, há variações nesses dados, embora haja congruência no sentido geral da evolução da prestação de serviços por prestador. 
executar a política do Conselho de Desenvolvimento Social como instrumento de apoio financeiro a programas e projetos de caráter social nas áreas de saúde, saneamento, educação, trabalho, previdência e assistência social. ${ }^{47} \mathrm{Da}$ dos de 1977 indicam que do total de financiamentos naquele ano 70,9\% foram direcionados para o setor público, atendendo assim a dispositivo legal no sentido de favorecer os investimentos públicos, reservando ao setor privado no máximo 30\% dos recursos do FAS. Entretanto, no setor de saúde e previdência esse limite não foi obedecido, e apenas $20,5 \%$ dos financiamentos foram para o setor público e 79,5\% direcionados para o setor privado, contrastando com a área da educação na qual a proporção foi de $88 \%$ para o setor público (Oliveira \& Teixeira, 1986).

Essa diferença entre os dois setores é um indicativo da perspectiva privatizante que caracterizou a expansão da assistência médica no Brasil, além de mostrar a capacidade de ação política dos atores favorecidos pela opção governamental. A entidade representativa dos hospitais, a Federação Brasileira de Hospitais ( $\mathrm{FBH})$, pressionou o governo visando garantir o favorecimento do setor privado na aplicação dos recursos do FAS. ${ }^{48} \mathrm{O}$ resultado dessa pressão foi que esses empréstimos a juros baixos beneficiaram o setor privado, proporcionando impulso à remodelação e à ampliação dos hospitais da rede privada no eixo Rio-São Paulo. ${ }^{49}$ Correlatamente, eram intensas as pressões

47 O FAS era composto de duas contas distintas. A primeira, de menor monta, era destinada a transferências e repasses diretos a órgãos do setor público. A segunda, composta de aplicações a cargo da Caixa Econômica Federal que podiam ser direcionadas também ao setor privado. A primeira conta era alimentada pelas rendas líquidas das loterias Federal e Esportiva; a segunda, por parcela da renda bruta das loterias Esportiva e Federal, recursos dos lucros operacionais da CEF, recursos orçamentários e convênios com outras instituições. Um terço desses recursos era mobilizado a custo zero; os demais, com custo financeiro contratual. Os critérios para a concessão de recursos eram: áreas periféricas ou deprimidas, cidades com menos de 50 mil habitantes, zonas rurais e áreas de execução de grandes projetos de interesse governamental.

48 O volume de propostas encaminhadas pelo setor é expressivo da utilização desse instrumento de financiamento público: de 703 propostas de financiamento, 73\% referiam-se a leitos hospitalares, predominando a criação ou expansão de hospitais privados com fins lucrativos. Desses, 63\% eram das regiões Sudeste e Sul (dados do Inamps, s.d., apud Oliveira \& Teixeira, 1986).

49 A expansão do setor privado em razão do FAS foi duramente contestada durante o processo constituinte pelo então presidente da Federação Brasileira dos Hospitais, Sílio Andrade. Citando documento da Caixa Econômica Federal, segundo seu depoimento no período de 1975 a agosto de 1985 foram financiados pelo FAS 482 hospitais e 40.994 leitos, dos quais 26.181 para o setor privado, o que corresponderia a apenas $6,5 \%$ do total de leitos particulares implantados pela iniciativa privada no período. Mesmo sendo possível a supervalorização do papel do FAS no financiamento da expansão da rede hospitalar privada, esses dados reforçam o favorecimento dos hospitais privados para a concessão de financiamentos subsidiados (cerca de $64 \%$ do total de leitos financiados), o que não teve correspondência no setor educação. 
contra a expansão do setor hospitalar estatal, considerada como algo 'estatizante', argumento que contou com o apoio de outros setores, em uma conjuntura caracterizada por forte movimento antiestatização.

Outra forma de articulação da Previdência Social com o setor privado ocorreu mediante o estabelecimento de convênios com empresas nos termos dos quais, mediante um subsídio, a empresa passava a arcar com a responsabilidade pela atenção médica a seus empregados, desobrigando o INPS da prestação direta de tais serviços. ${ }^{50} \mathrm{Na}$ maioria dos casos, em vez de prover diretamente os serviços médicos, a empresa comprava os serviços de outra empresa especializada, chamada de 'medicina de grupo', 'empresa médica' ou 'grupos médicos’, estabelecendo-se um acordo triangular entre INPS/empresa empregadora/empresa médica.

A prática de as empresas manterem serviços de saúde tem origem em seus próprios serviços ou departamentos médicos, que desde final do século XIX já existiam nas grandes empresas com as funções de seleção de pessoal e controle do absenteísmo na força de trabalho empregada, analisando casos de doenças, faltas e licenças (Oliveira \& Teixeira, 1986). Caracterizados por exercerem maior controle do que os serviços externos à empresa como a Previdência Social, ${ }^{51}$ possibilitavam o retorno mais rápido da força de trabalho à produção, além de funcionarem como uma política de pessoal mais atraente por meio de uma estratificação na qualidade do atendimento. No processo de desburocratização e modernização das grandes empresas, cresceu a prática de comprar serviços de outras empresas especializadas, que se reproduziu também com a assistência médica mediante a contratação de empresas médicas.

Nos contratos que estabelecem com a empresa conveniada, as empresas médicas são remuneradas pelo sistema de pré-pagamento, recebendo um valor fixo por trabalhador assegurado, e o total é pago mensalmente ao grupo médico pela empresa compradora de serviços, independentemente da quantidade e dos tipos de atos médicos realizados no período. A lógica desse tipo de arranjo é que a empresa médica, na perspectiva de uma lógica mercantil,

\footnotetext{
50 O INPS reembolsava à empresa cerca de 5\% do maior salário mínimo regional por trabalhador coberto na empresa que montava um serviço de saúde próprio.

51 Oliveira e Teixeira (1986) mostram dados de 1976 segundo os quais 93\% dos pacientes de trabalho atendidos pelo INPS eram considerados incapacitados temporariamente, enquanto apenas $49 \%$ dos atendidos por convênios ficavam afastados de suas funções.
} 
busca a diminuição progressiva do custo dos tratamentos ou dos serviços prestados, evitando estimular o consumo de serviços médicos. Expressão dessa lógica era a prática das empresas de definirem critérios para a celebração de convênios com base em estudos sobre a população coberta, buscando empregados com melhores condições de saúde, além de procurarem limitar o custo com consultas e internações por meio de medidas preventivas.

Os primeiros convênios tripartites - Previdência Social/empresa empregadora/empresa de medicina de grupo - surgiram no âmbito dos IAPs. O primeiro foi estabelecido em 1964 pelo IAPI com a Volkswagen, seguido de outros, como o Instituto de Aposentadorias e Pensões dos Bancários (IAPB) e o Instituto de Aposentadorias e Pensões dos Comerciários (IAPC). Entretanto, essa forma institucional de organização dos serviços de saúde em moldes empresariais só adquire dimensões significativas a partir de 1968, no âmbito do recém-criado INPS, que incorporou a prática de convênios após a unificação dos institutos, favorecendo a expansão da medicina de grupo. ${ }^{52}$ Essa expansão era restrita aos locais de concentração das grandes empresas empregadoras. Nos anos 70, mais de 70\% dos grupos médicos e de seus beneficiários estavam localizados na cidade de São Paulo, atendendo à mão-de-obra das grandes empresas (Abramge apud Possas, 1981; Gentile de Melo, 1984). A própria legislação favorecia a seletividade ao exigir da empresas 'porte e organização administrativa' para a celebração do convênio com o INPS..$^{53}$

A política de convênios INPS/empresa teve diversas conseqüências para a conformação institucional da assistência à saúde e para a consolidação da

52 Em 1974 existiam 136 grupos médicos oficiais, cobrindo 2.845 firmas empregadoras; 6 milhões de beneficiários assistidos por empresas médicas, dos quais 3,5 milhões em convênios tripartites (previdência, empresas e grupos médicos); e 2,5 milhões em contratos sem a participação do INPS. Dados do INPS de agosto de 1977 já mostram a existência de 4.699 convênios tripartites, "abrangendo 1.801.082 segurados que, com os dependentes, perfaziam 4.337.187 beneficiários, ou seja, cerca de 10\% do total da população previdenciária” (Oliveira \& Teixeira, 1986: 228).

53 Dados da Abramge, publicados na imprensa em 1976, mostravam que os convênios com empresas atingiam 35\% dos beneficiários do INPS da Grande São Paulo e 10\% no interior do estado, perfazendo em conjunto $22 \%$ da população paulista - cerca de cinco milhões de pessoas. Dados de Gentile de Melo (1984) mostram que em 1970 existiam no estado da Guanabara 86.190 empresas filiadas ao INPS, das quais apenas $122(0,14 \%)$ mantinham convênio. Entretanto, essas empresas possuíam 90.443 empregados (6,8\% dos segurados do estado). Empresas com convênio no estado da Guanabara tinham em média 740 empregados, quando a média geral era de 16 . O valor médio das aposentadorias era de Cr\$229, ao passo que nas empresas com convênio esse valor pulava para Cr\$ 624. O valor médio do auxílio-doença era de Cr\$173, mas para os segurados das empresas com convênio era de Cr\$309. 
assistência prestada pelas empresas aos seus empregados. Em primeiro lugar, os convênios tripartites possibilitam o crescimento da assistência médica sob controle da empresa, com parte dos custos assumida pela Previdência Social, fortalecendo uma forma de prática médica voltada para ações que interessavam prioritariamente à produtividade. Embora a prática das grandes empresas da prestação de assistência médica aos seus empregados anteceda a participação do setor público por meio de convênios,${ }^{54}$ com base nesse instrumento essa prática empresarial vai ser incentivada pelos subsídios governamentais.

Mas, além de financiar, pelo menos parcialmente, a assistência médica anteriormente já assumida pelas grandes empresas com recursos próprios, a Previdência arca com parcelas crescentes das atividades médicas mais raras, complexas e de longa duração aos empregados cobertos pelos convênios. ${ }^{55}$ Criados para se beneficiar do regime da economia de escala, os convênios passam a ser responsáveis pela pulverização de recursos do INPS, que fica com os encargos mais onerosos e as prestações mais pesadas. Beneficiando empregados das grandes empresas, promove também o esvaziamento progressivo dos serviços prestados diretamente pelo INPS (Melo, 1981; Oliveira \& Teixeira, 1986).

$\mathrm{O}$ incentivo financeiro via convênios teve também o efeito de reforçar a prática das empresas de assumirem a assistência de seus empregados, de tal forma que, independentemente do subsídio governamental, vai se expandir essa assistência empresarial, na maioria das vezes pela contratação de grupos médicos. Paulatinamente, essa forma de assistência privada vai ocupando espaço maior do que a própria assistência, com a participação do Poder Público, no âmbito das grandes empresas no eixo Sul/Sudeste, e será o pilar da assistência suplementar, conforme se discutirá no próximo capítulo.

Como marca da política de assistência à saúde desde suas origens, essa opção pública mostra as suas contradições. Ao mesmo tempo que amplia a cobertura previdenciária e a prestação da assistência médica, favorece a

54 Em 1970, 50\% das empresas conveniadas do então estado da Guanabara eram estatais ou estrangeiras, que em sua maioria já prestavam assistência médica aos empregados.

55 Normas relativas aos convênios aprovadas em 1969 desobrigavam as empresas da assistência aos empregados que precisassem de reabilitação, atendimentos médicos de custo elevado, tratamento dos tuberculosos, doenças mentais e casos de riscos catastróficos, como cirurgia cardíaca, microneurocirurgia, transplantes, implantes e politraumatismos, por exemplo. 
seletividade ao subsidiar práticas empresariais restritas às grandes empresas além de reforçar a vinculação da política de assistência à saúde com a relação contratual de trabalho, favorecendo os trabalhadores em situação privilegiada, na contramão da uniformização pretendida com a unificação dos IAPs e em direção contrária à universalização.

Várias formas de desigualdades entre diferentes estratos dos trabalhadores se introduzem nessa forma de assistência médica. Em geral, os convênios eram estabelecidos com empresas de grande porte, com mão-de-obra mais especializada e salários superiores. Também os grupos médicos tendem a se concentrar nas regiões mais industrializadas e urbanizadas. Como o subsídio previsto no convênio com o INPS não era suficiente para cobrir os gastos, ao mesmo tempo que exigia a cobertura de todos os empregados, não interessava a todas as empresas, particularmente as de pequeno e médio porte, e muitas preferiam os convênios sem a intermediação do INPS. Alguns convênios diretos com o grupo médico cobriam apenas uma parcela dos trabalhadores, em geral os de maior qualificação. Em conseqüência, durante as décadas de 60 e 70 a diferenciação de serviços não se daria mais entre categorias profissionais, mas entre qualificações profissionais (Giffoni, 1991). Incentivadas e legitimadas pela iniciativa pública dos convênios, a partir daí se desenvolveram as formas eminentemente privadas de assistência, as quais incluíam uma grande diversidade de possibilidades de planos e contratos alternativos.

Esse tipo de arranjo mostra que o rompimento do pacto corporativista, que se expressava institucionalmente na separação dos antigos IAPs por categoria profissional, não dará lugar a uma uniformidade entre os trabalhadores assalariados, que constituíam a clientela da política assistencial do período. As diferentes formas de diferenciação vão recriar as demandas particularistas de outra natureza, dessa vez vinculadas ao contrato de trabalho, e não à categoria profissional como ocorria antes da unificação dos IAPs.

Em síntese, ao mesmo tempo que se ampliavam as clientelas da Previdência Social, ampliavam-se também as diferentes modalidades assistenciais, por meio das várias formas de articulação com o setor privado. A essas diferenciações correspondia uma segmentação da clientela, no âmbito mesmo da Previdência Social, de acordo com a forma de acesso à assistência. Isso se traduzia em diferenciação quanto ao tipo e à qualidade dos serviços oferecidos. 
A variação na forma de pagamento dos serviços comprados tinha também conseqüências para a assistência. No setor conveniado, em que a empresa recebia um subsídio fixo por segurado e remunerava também a empresa médica contratada sob a forma de pré-pagamento, independentemente da utilização de serviços, a realização de procedimentos tendia a ser bem menor. Ao contrário, no caso dos serviços prestados pela rede privada contratada que recebia por US, o sistema de pagamento incentivava a realização de maior número de procedimentos para aumentar a lucratividade dos prestadores. ${ }^{56}$

\section{Crise: novos mecanismos institucionais e propostas alternativas}

A institucionalização desses mecanismos, por meio dos quais se expandiu a assistência médica, propiciada pelo poder público, levou à constituição de uma estrutura complexa e diversificada. Correlatamente, foram se constituindo atores e interesses também diversificados, no âmbito tanto do setor público quanto do privado. Este último se fracionava segundo interesses particularizados, sendo os principais os relativos aos prestadores de serviço representados principalmente pela $\mathrm{FBH}$ e pela $\mathrm{AMB}$, as empresas médicas, representadas pela Abramge, e o setor conveniado.

Apesar de o período ser caracterizado pelo predomínio de idéias privatizantes no âmbito da burocracia previdenciária, altamente penetrada pelos interesses dos setores privados, a crítica ao modelo assistencial em desenvolvimento era também expressiva. Parte da burocracia defendia o fortalecimento do setor próprio e a criação de mecanismos mais eficientes de controle do setor privado, com base na crítica aos fatores indutores de corrupção e de suas conseqüências negativas sobre o equilibrio financeiro da Previdência Social.

\footnotetext{
Essa diferenciação pode ser exemplificada pela relação entre o número de consultas por internação. Em 1975, no sistema próprio mais o contratado, estimulado pelo sistema de pagamento por US, a relação consultas/internações era de 12,3, ao passo que no sistema de convênios, em regime de pré-pagamento, essa relação era de 56,9 (Possas, 1981). Como destaca Possas, outras variáveis deveriam também influenciar no menor número de internações dos segurados assistidos pela modalidade de convênio, particularmente as melhores condições de vida em razão de melhores salários e localização nas grandes cidades. Mas as análises do período são unânimes em identificar na forma de pagamento por US um incentivo às internações, mesmo desnecessárias, o que era, inclusive, amplamente denunciado pela própria Previdência Social.
} 
Duas propostas de novos mecanismos institucionais são ilustrativas do conflito de idéias em uma conjuntura já caracterizada como de crise. A primeira, expressão dos interesses dos produtores privados de serviços de saúde; a segunda, expressão da oposição à forma privatizada da assistência pública. A primeira proposta foi o Plano Nacional de Saúde, elaborado em 1968, sob a orientação do então ministro Leonel Miranda, que expressa uma concepção sobre as relações entre os setores público e privado com valorização do segundo (Oliveira \& Teixeira, 1986; Donnangelo, 1975; Luz, 1986). Embora atribuísse ao Poder Público a atenção à saúde, o plano determinava que as atividades de assistência médica deveriam ser de natureza primordialmente privada, sem prejuízo do estímulo, da coordenação e do custeio parcial do Poder Público, prevendo, inclusive, o arrendamento dos hospitais governamentais para a iniciativa privada. Ao implicar sensível redução da participação direta do governo na produção de serviços, o plano era defensor da prática médica liberal, propondo o regime de livre escolha do médico e compra direta de serviços em um mercado livre, com financiamento apenas parcial com recursos públicos previdenciários, ficando o restante a cargo do cliente.

O plano encontrou várias resistências, por parte tanto dos técnicos da Previdência, defensores da ampliação dos serviços próprios, quanto dos críticos da medicina liberal. Fracassa depois de ter sido implantado apenas experimentalmente em algumas localidades.

A segunda proposta foi a portaria 48 do INPS, de 1972, a qual expressa a tentativa de alterar a política assistencial dominante. Mesmo sem ter obtido efeitos concretos, apresentou propostas alternativas. Entre outras definições, estabelecia uma hierarquização das modalidades de serviços, privilegiando aqueles próprios da Previdência e definindo o estabelecimento de convênios com estados e municípios quando exauridas as possibilidades de serviços próprios. Apenas em última hipótese, previa contratos e convênios com organizações privadas. Como expressão dessa proposta, foram tomadas providências no sentido de ampliar a capacidade hospitalar própria da Previdência Social mediante inaugurações e reativações de hospitais (Melo, 1984), que, entretanto, não foram suficientes para alterar o padrão vigente.

A expansão indiscriminada da contratação de serviços privados foi se mostrando economicamente inviável, em razão dos altos custos do regime de 
pagamento por serviços prestados e da ausência de controle da Previdência sobre as unidades contratadas. O próprio modelo de prestação de serviços impunha limites à expansão da cobertura médico-assistencial mediante um padrão de organização dos serviços médicos cuja hegemonia era detida pelos produtores privados. Em meados da década de 70, a corrupção atingiu níveis que ameaçavam o equilíbrio financeiro, criando-se uma situação de crise, seguida de reformas (Oliveira \& Teixeira, 1986).

Uma das alternativas para o impasse que se apresentava para a expansão da assistência médica em uma situação de crise de financiamento do modelo assistencial foi a ampliação de outras modalidades de convênios: os convênios com sindicatos, universidades, prefeituras e governos estaduais, com a utilização das estruturas dessas instituições como forma de aumentar a cobertura com custos mais reduzidos para a Previdência Social e como alternativa para frear a expansão do credenciamento da rede privada. A ênfase dada a esses convênios na década de 70 visava corrigir distorções criadas pelo foco na hospitalização e pelo pagamento por US ao setor contratado, passando-se a pagar os serviços conveniados de forma global. ${ }^{57}$ Essas outras formas de convênios com órgãos estatais (governos estaduais e municipais, universidades) e sindicatos, embora não tenham alcançado a importância dos outros componentes do ‘complexo previdenciário' nesse período, vão apresentar modelos institucionais alternativos, alguns dos quais se desenvolverão na década seguinte. ${ }^{58}$

57 De acordo com Possas (1981), a crise financeira da assistência médica previdenciária atinge seu ponto máximo em 1977, ano marcado por uma crise nos hospitais credenciados, que, em razão do não-pagamento pelo INPS das contas hospitalares, ameaçam entrar em greve e recusar atendimento aos segurados. Nesse ano, o debate na imprensa é intenso: o INPS denuncia abusos de internações desnecessárias e hospitais reclamam do não-pagamento, acusando a pretensão de privatização da medicina.

58 No caso dos convênios com secretarias estaduais de Saúde, o INPS transferia recursos de seu orçamento para atendimentos em tisiologia, mediante um contrato global, e a secretaria se encarregava do atendimento. Os convênios com universidades/hospitais de ensino, apesar de estarem previstos desde 1968, só começaram a ser realizados a partir de 1971, inicialmente efetuando o pagamento por US, com os mesmos parâmetros usados para os hospitais privados, embora, além da assistência, fossem encarregados da formação de recursos humanos e da realização de pesquisas. Após 1974, muda a forma de convênio, que passa a ser realizado por meio de uma modalidade de contrato global em que o pagamento é feito na forma de um subsídio variável em razão do número e do tipo de altas, suprimindo o pagamento por unidade de serviço nos hospitais de ensino. 
Esses tipos de convênios com o setor público, apesar de minoritários, provocavam reação da $\mathrm{AMB}$ e da $\mathrm{FBH}$, contrárias à privilegiação do setor público e às modalidades de convênio global ou pagamento por diária global, pois defendiam a remuneração por US, altamente favorável ao prestador privado. No caso dos convênios com os hospitais de ensino, os interesses dos prestadores privados demonstraram um importante poder de veto, conseguindo paralisar o ritmo de integração dos hospitais universitários à Previdência Social, de forma que em 1978 apenas 25 das 75 escolas firmaram o convênio (Escorel, 1998).

Nos convênios com sindicatos, a lógica governamental não era tanto a redução de custos, mas tinha o caráter político. Após 1964, o governo estimulou as práticas de assistência social, de forma a deslocar o centro das preocupações dos sindicatos para a prestação dos serviços. Em 1970, foi criado o Programa de Valorização da Ação Sindical, do Ministério do Trabalho, como forma de estímulo ao 'sindicato de serviços', facilitando aos sindicatos a abertura de ambulatórios médicos, que adquiriram o direito de assinarem convênio com o INPS (Possas, 1981). Na primeira metade da década de 70, a Previdência optou pelo incentivo aos serviços médicos de sindicatos em detrimento dos convênios-empresa. Apesar de grande ampliação, os convênios com sindicatos mantiveram-se bastante reduzidos em termos relativos (Cordeiro, 1984; Bahia, 1999). ${ }^{59}$ Em 1979, os convênios com empresas são extintos, embora a assistência empresarial não deixasse de receber outros incentivos governamentais, sendo o principal, a partir de 1974, a autorização para a dedução do Imposto de Renda dos gastos com saúde das empresas.

Um instrumento normalizador da assistência médica previdenciária de grande impacto foi o Plano de Pronta Ação (PPA). Estabelecido em 1974, o PPA compreendeu um conjunto de medidas criadas para disciplinar e organizar o funcionamento dos diferentes setores componentes do complexo previdenciário e, ao mesmo tempo, criar condições para atender à necessidade

\footnotetext{
9 Em 1976, os convênios com sindicatos correspondiam a 11,44\% do total de convênios, aumentando para 13,46 no ano seguinte. Os convênios com empresas constituíam, nos mesmos anos, cerca de 85,69\% e 83,23\%, respectivamente (Possas, 1981; Aguiar, 1979). Em 1977, os convênios com sindicatos cobriam mais de seis milhões de beneficiários em todo o país, cerca de $66 \%$ deles concentrados nos estados de São Paulo, Rio Grande do Sul, Rio de Janeiro e Pernambuco.
} 
de expansão de cobertura, tornando os serviços de saúde mais acessíveis. Esse plano expressou a reinstalação no Ministério da Previdência dos tecnocratas do antigo IAPI, de orientação privatista (Melo, 1984), e teve como resultado o reforço do modelo de expansão da assistência por meio do setor privado. Seu objetivo era utilizar toda a capacidade instalada, tanto pública quanto privada, e garantir a ampliação do atendimento na rede de serviços privados, articulando todos os serviços de assistência médica no país.

Para alcançar esse objetivo, vários mecanismos foram criados. Em primeiro lugar, foi estabelecida a universalização do atendimento nos casos de emergência, independentemente da condição de segurado da Previdência Social. A princípio restrito aos estabelecimentos públicos, o atendimento de emergência foi estendido aos privados e, em razão da baixa capacidade de controle governamental, constituiu-se como mais uma possibilidade de fraude, pela realização de atendimentos não-emergenciais.

Outro mecanismo que também iria atender às reivindicações dos produtores privados, ao facilitar a incorporação das camadas médias aos serviços médicos da Previdência, foi a decisão de facultar ao segurado a opção por instalações especiais nos hospitais particulares contratados pela previdência, com a complementação de valores sendo paga pelo próprio cliente ao hospital. Uma conseqüência dessa medida foi a tendência de os hospitais passarem a manter uma reserva de leitos para as 'instalações especiais', com a conseqüente falta de leitos comuns para os segurados que não arcassem com os custos adicionais (Gentile de Melo, 1984).

Um terceiro mecanismo que reforçou a compra de serviços privados foi o veto à ampliação da rede própria hospitalar. Ao mesmo tempo, à rede própria da Previdência Social já existente o PPA destinou a prestação de assistência hospitalar de alta especialização, decisão que pode ser vista como o reconhecimento oficial do padrão técnico mais elevado dos hospitais públicos.

Um quarto mecanismo foi a normalização de uma assistência fundamentada no regime de livre escolha, parâmetro típico do mercado. O PPA previa a prestação de serviços por intermédio de cooperativas médicas - forma alternativa de organização empresarial de serviços médicos que emergiu de um movimento de oposição das entidades médicas à medicina de grupo e em 
plena expansão no período. A preferência foi dada aos prestadores que assegurassem a livre escolha de hospitais, clínicas e profissionais, característica das cooperativas, privilegiando o regime de livre escolha e a diferenciação de clientelas e tendo como forma de pagamento dos serviços contratados a Unidade de Serviço.

O resultado do PPA foi a aceleração dos contratos de prestação de serviços de saúde com o setor privado na forma de convênios e contratos. Em escala menor, cresceram também os convênios com a rede oficial nãoprevidenciária - hospitais universitários e secretarias estaduais e municipais de Saúde. Como conseqüência, após a implantação do PPA ocorreu um crescimento expressivo do número de serviços médicos. O crescimento em todos os tipos de procedimentos foi acentuadamente superior na rede privada em detrimento dos serviços realizados na rede própria da previdência. ${ }^{60} \mathrm{O}$ PPA é, assim, uma expressão inequívoca da direção da política de saúde que indicava a universalização da cobertura assistencial, alicerçada na compra de serviços privados e com restrição dos serviços estatais às áreas de menor interesse empresarial: ambulatórios para atenção primária e hospitais de maior complexidade tecnológica e maior custo.

Na seqüência das mudanças institucionais na Previdência Social, foi criado, em 1977, o Sistema Nacional de Previdência e Assistência Social (Sinpas), subordinado ao MPAS, que operou uma divisão técnica do trabalho, criando ou incorporando diversos organismos para as diversas tarefas da Previdência. ${ }^{61}$ Integrando o Sinpas, foi criado o Instituto Nacional de Assistência Médica da Previdência Social (Inamps), que aglutinou a assistência médica concedida por todos os órgãos previdenciários e incorporou a receita desses órgãos. ${ }^{62}$

60 O número de internações aumentou em 66\% no período de 1974 a 1977; o de consultas, em 157\%; e o de serviços de complementação diagnóstica, em 119\% (INPS apud Oliveira \& Teixeira, 1986).

${ }^{61}$ O Sinpas era integrado pelas seguintes entidades: Instituto Nacional de Previdência Social (INPS); Instituto Nacional de Assistência Médica da Previdência Social (Inamps); Fundação Legião Brasileira de Assistência (LBA); Fundação Nacional de Bem-Estar do Menor (Funabem); Empresa de Processamento de Dados da Previdência Social (Dataprev); Instituto de Administração Financeira da Previdência e Assistência Social (Iapas); e, como órgão autônomo, a Central de Medicamentos (Ceme).

62 O Inamps absorveu os serviços da assistência médica do INPS, do Funrural, do Ipase, da Sasse e da LBA. 
Tal iniciativa expressou a aproximação do princípio da universalização da seguridade social ao desvincular cada vez mais o atendimento médico da condição de segurado, embora a base do financiamento continuasse a ser a contribuição do segurado. A expansão da assistência médica não foi acompanhada da ampliação das fontes de financiamento, aprofundando uma crise que já se configurava desde a década anterior. Oficialmente, a crise da Previdência foi creditada ao desenvolvimento da assistência médica; para os analistas, ao modelo de privilegiação do produtor privado de serviços - de alto custo e difícil controle. ${ }^{63}$

O agravamento da crise financeira da Previdência Social na década de $80^{64}$ marcará um momento de inflexão, com o surgimento de propostas de políticas alternativas para o sistema de saúde que enfatizavam a reversão do modelo de privilegiação dos produtores privados de serviços via canalização dos recursos previdenciários para o setor público. Mais ou tão importante que a crise financeira da Previdência e a incapacidade de sustentação desse modelo é a coincidência da crise com o processo de democratização do país, que coloca em cena outros atores políticos, "quebrando o monopólio dos anéis burocráticos previdenciários na definição e implementação das políticas de saúde" (Mendes, 1993: 28).

Em um contexto de luta política entre projetos alternativos de políticas de saúde é que vai se mostrar a possibilidade de alterar a configuração do modelo médico-assistencial privatista durante a década de 80 , no âmbito, contudo, dos constrangimentos apresentados por essa complexa estrutura institucional.

63 As causas apontadas por Oliveira e Teixeira (1986) que sintetizam as principais análises do tema relacionam a crise da Previdência a uma contradição estrutural; ou seja, a crescente expansão do sistema não foi acompanhada de alterações na restrita base financeira, configurando-se uma crescente absorção de faixas da população coberta em direção a um modelo de cidadania universal, juntamente com um regime financeiro baseado no modelo de relação contratual. A esse fator estrutural acrescentam-se tanto fatores externos quanto internos ao sistema previdenciário. Entre os primeiros, destacam-se: a queda dos salários reais e a redução do crescimento do emprego, desacelerando a receita de contribuições em um quadro de recessão; o aumento das sonegações; e a diminuição das transferências da União. Entre os fatores internos, a ênfase é atribuída aos problemas de arrecadação e de gestão dos recursos; e, sobretudo, à privilegiação dos produtores privados de serviços de assistência médica, com uma forma de repasse de recursos por meio de instrumentos corruptores, tornando o modelo incontrolável, além de sofisticado, o que contribuiu para tornar crônica a crise (Oliveira \& Teixeira, 1986).

64 Braga e Paula (1981) mostram que o déficit do Sinpas (diferença entre a receita e a despesa) atingiu, em 1980, Cr\$ 46,8 bilhões. 


\section{Síntese}

Neste capítulo foi analisada a constituição da política de assistência à saúde no Brasil, destacando as principais características do modelo de assistência estruturado na década de 60, embora delineado desde os anos 30. Esse corte temporal se justifica, uma vez que somente a partir dos anos 60 se manifestou a disposição pública de tornar a assistência à saúde uma política governamental, como parte inerente da Previdência Social. Essa disposição se traduziu em decisões efetivas no sentido de expandir a assistência tanto quanto a cobertura, como na destinação de recursos previdenciários para a saúde. Para a concretização da assistência pública, foi estabelecido um arcabouço legal e institucional que definiu os parâmetros do desenvolvimento da assistência no Brasil, os quais revelam o sentido privatizante da forma de expansão dos cuidados médicos que caracterizou a assistência pública desde sua constituição. Essa perspectiva privatizante não significou a assunção privada da responsabilidade pela assistência à saúde em face de uma ausência do Estado. Ao contrário, é no movimento de expansão da atuação governamental no âmbito da saúde que se opta, ao mesmo tempo, pela delegação ao setor privado de grande parte das atividades de prestação dos serviços e, até mesmo, da gestão da assistência por meio de convênios com empresas, que, favorecidas por recursos governamentais, são incentivadas a assumir a responsabilidade pela assistência aos seus empregados. Ao ampliar progressivamente a prestação da assistência por intermédio das instituições previdenciárias, consolidando a atuação pública no campo da saúde, o próprio Estado se desenvolve e vai delineando suas características, demonstrando sua porosidade aos interesses privados, ao mesmo tempo que aprofunda sua intervenção na área da saúde valendo-se de formas diversas de relacionamento com o setor privado.

A política de assistência à saúde levou à constituição de um conjunto de instituições de saúde e de atores, ao favorecer a expansão das atividades privadas. Em conseqüência, ao gerarem determinados padrões de assistência, as políticas que foram estabelecidas no pós-64 também influenciaram o processo político posterior, caracterizado por pressões em torno de recursos públicos, dos quais passam a depender muitas das atividades privadas. Por essas razões, pode-se dizer que essas políticas vão configurar processos martingales, 
que tornam as escolhas posteriores dependentes dessas escolhas anteriores. Ao estabelecerem regras, expectativas e comprometimentos, as políticas definidas vão afetar o desenvolvimento da trajetória da política de assistência, particularmente ao afetar o comportamento dos atores políticos engendrados ou favorecidos por elas. É nesse sentido que a política de assistência à saúde definida a partir dos anos 60 funciona com a variável independente para a compreensão da política vigente no seu formato dual: público e privado.

A reconstituição do ponto de partida dessa trajetória tratou de identificar as diferentes escolhas, contingentes ou respostas a pressões sociais, por meio das quais foi estruturada a assistência à saúde de caráter público. As conseqüências institucionais ou políticas dessas escolhas favoreceram a consolidação da assistência privada paralelamente à pública e se constituíram em constrangimentos para uma reforma mais ampla, tal como proposta no processo constituinte. Os principais traços dessa política são sumarizados a seguir.

\section{A cidadania regulada: assistência à saúde vinculada ao trabalho, e não como um projeto de inclusão universal e igualitária}

A assistência médica desenvolveu-se no Brasil, no âmbito da instituição previdenciária, como uma prestação de serviços de saúde aos segurados da Previdência Social, tendo, portanto, um caráter secundário, no sentido de não se enquadrar em um projeto universal de assistência à saúde e, ainda, sem prever fontes próprias de custeio independentes dos recursos previdenciários concebidos para outras destinações - os benefícios previdenciários de natureza pecuniária. A essa imbricação com a Previdência Social corresponde uma total desarticulação da assistência médica pública com as demais ações de saúde, de caráter coletivo, localizadas institucionalmente no âmbito do Ministério da Saúde. Além disso, acompanhando a fragmentação institucional da Previdência Social, fracionada em diversos institutos estabelecidos em razão do vínculo dos segurados com a atividade produtiva, a assistência, já na sua origem, será diversificada e desigual entre os seus diversos segmentos. Assim, o fato de a assistência nascer imbricada à Previdência Social não propiciou condições favoráveis à constituição de uma perspectiva universalista para a saúde. A assistência nasce como seguro e de um arranjo corporativo, e não de uma demanda coletiva, além de, como toda a Previdência Social, ser uma concessão 
no âmbito do direito do trabalho, e não uma conquista do estatuto de cidadania, entendida como a inclusão universal e igualitária.

O desmantelamento da estrutura corporativa pós-64, com a unificação dos IAPs, teve o efeito concreto de alargar consideravelmente a cobertura previdenciária, particularmente a partir da década de 70 , quando ela passa a incluir praticamente todos os trabalhadores. Com a ampliação da cobertura previdenciária, dá-se também a expansão da assistência médica pública, fato que indica a universalização que, entretanto, só será efetivada na Constituição de 1988. Essa ampliação não se deu apenas como uma conseqüência lógica, mas em razão de uma política explícita no sentido de a Previdência Social incorporar a assistência como uma de suas atribuições.

Entretanto, a tendência para a universalização não foi o resultado de uma reivindicação dos trabalhadores, os quais, ao contrário, desenvolveram uma visão corporativa e resistiram à unificação da Previdência Social, que significou a uniformização dos benefícios e serviços, bastante prejudicial para algumas categorias. Sem suporte político para uma assistência universal e igualitária, no seu desenvolvimento vão se dando movimentos contraditórios de equalização e segmentação - marcas que caracterizarão a assistência à saúde ainda hoje. A tendência à ampliação da cobertura no sentido da universalização é contrabalançada pelo favorecimento de novas formas de diferenciação da assistência, com a participação das empresas empregadoras, a partir do desenvolvimento de formas privadas de assistência no âmbito das empresas com financiamento parcial pela Previdência Social. Para os trabalhadores inseridos nos ramos menos dinâmicos da economia, nas regiões mais pobres ou no interior do país, destinava-se a assistência pública previdenciária. Diferentemente, aqueles inseridos em grandes empresas e nas grandes cidades da região Sudeste passam a ser cobertos pela assistência empresarial, com ou sem a participação da Previdência Social, diretamente administrada pela empresa empregadora ou por empresas ou cooperativas médicas.

A opção pela compra de serviços: expansão da rede prestadora privada e atrofia da capacidade governamental, tanto prestadora quanto reguladora

O atendimento da demanda ampliada por serviços de saúde não pôde contar com uma rede de serviços públicos suficiente, previamente montada. 
Tampouco se fez acompanhar da criação de uma estrutura pública de prestação de serviços correspondente, uma vez que a escolha política foi pela privilegiação da compra de serviços a prestadores privados, particularmente hospitais e serviços ambulatoriais mais complexos. Com a expansão da assistência médica previdenciária, as instituições privadas prestadoras de serviços de saúde que já se desenvolviam autonomamente em um mercado restrito, em razão tanto do baixo poder aquisitivo de grande parcela da população quanto da tecnificação da atenção médica, com conseqüências sobre a elevação de seus custos, têm a possibilidade de expansão pela via da política de assistência à saúde. Ao mesmo tempo, por meio de mecanismos de veto, é restringido o desenvolvimento da rede pública prestadora de serviços de saúde, particularmente hospitais.

A partir da década de 60, o setor público passa a ter um papel importante na organização da estrutura de assistência à saúde na condição de principal comprador de serviços e, conseqüentemente, na forma de expansão da rede assistencial. Mesmo tendo sido formuladas alternativas diferentes a esse modelo de expansão da assistência pública, as escolhas que prevaleceram, mediante vários mecanismos, aprofundaram a expansão da compra de serviços, particularmente nos anos 70. Um desses mecanismos permitiu a incorporação de setores médios à assistência pública, com parte dos custos assumida individualmente, em substituição à medicina liberal de custos crescentes. Apesar das críticas a uma suposta ‘estatização' da saúde pelos provedores de serviços privados, será por meio da ação e do financiamento estatais para setores cada vez mais amplos da sociedade que eles desenvolverão sua capacidade de produção de serviços. A contrapartida foi o baixo desenvolvimento da capacidade estatal, principalmente para a produção de serviços hospitalares, o que tornará o Poder Público dependente do setor privado para a expansão da assistência. Ao mesmo tempo, não se desenvolveu a capacidade reguladora do Estado, que vai ser fortemente capturado pelos interesses privados mediante, principalmente, os anéis burocráticos estabelecidos no âmbito das instituições previdenciárias. Essa situação se traduzirá na proeminência dos interesses privados sobre os coletivos, além da elevação dos gastos assistenciais a níveis que acabariam por comprometer a capacidade de financiamento governamental da assistência. 


\section{Os convênios/empresa: origem da assistência privada autônoma}

Outro mecanismo de articulação com o setor privado, visando também aumentar a cobertura assistencial, foi o recurso aos convênios com empresas para que assumissem a assistência para seus empregados em troca de um subsídio público. Os convênios legitimaram e expandiram a prática das empresas de se responsabilizarem pela assistência à saúde de seus empregados. Um desdobramento dessa prática foi a terceirização da assistência via convênios das empresas empregadoras com empresas médicas (ou medicina de grupo), cujo desenvolvimento levou também ao surgimento das cooperativas médicas. Novas instituições de saúde vão se desenvolver, estimuladas pelos incentivos governamentais, que serão o esteio do desenvolvimento posterior de uma assistência privada autônoma em relação ao setor público, particularmente a medicina de grupo e as cooperativas médicas. Favorecida indiretamente pela Previdência Social via convênios com empresas, a medicina de grupo vai encontrar nos convênios bilaterais com as empresas, sem a participação do INPS ou do Inamps, um mercado crescente que a levará a um desenvolvimento autônomo. Por sua vez, as cooperativas médicas, que inicialmente surgem como um movimento dos profissionais médicos contra as condições de trabalho impostas pela medicina de grupo e para garantir a autonomia do trabalho médico, encontrarão nesse mesmo mercado possibilidades de expansão fora da assistência médica previdenciária, integrando-se ao complexo médico-empresarial. Com a expansão desses dois segmentos, os prestadores de serviço privados vão se voltar para o atendimento dessa demanda efetivamente privada, deixando de se subordinar exclusivamente ao setor público, mas principalmente à lógica do setor privado autônomo em expansão.

Essa nova expansão autônoma será favorecida pelas contradições que o próprio modelo previdenciário criara, as quais vão se expressar na dificuldade de arcar com a expansão da demanda e com os altos custos da assistência, o que redundará na queda de qualidade dos serviços prestados e na insatisfação dos segurados. Entre essas contradições figura ainda a fragmentação de recursos previdenciários com o financiamento parcial da assistência médica das empresas, mantendo-se a responsabilidade pública pelos tratamentos mais caros. O mesmo acontece no caso dos segmentos autonomizados, cujos usuários teriam que continuar recorrendo à assistência pública para esses casos. 
A institucionalização de formas privadas epúblicas de assistência e a constituição de atores, interesses e estratégias

A forma de expansão da assistência médica de caráter público, no sentido da universalização de cobertura e tendo como locus as instituições previdenciárias, vai, em conseqüência, levar à constituição de um mix de instituições públicas e privadas em torno da política de saúde - por um lado, os prestadores de serviços, que podem ser tanto públicos quanto privados, os primeiros incluindo instituições previdenciárias, unidades estaduais, municipais e hospitais universitários; por outro, gestores de formas privadas de assistência à saúde subsidiadas por recursos públicos, como empresas, medicina de grupo, cooperativas médicas e sindicatos. Todos em conjunto irão constituir a estrutura institucional da política estabelecida e fixar relações diferenciadas com o setor público responsável pela política de assistência, dependendo da modalidade de vínculo e das regras de relacionamento correspondentes, que podem ser contratos com os prestadores privados ou convênios com empresas, sindicatos, órgãos públicos ou instâncias governamentais subnacionais. Um elemento importante nessa relação diferenciada é a forma de pagamento dos serviços: se na forma de US, estimula a realização de maior número de serviços médicos, particularmente incentivando, do ponto de vista financeiro, o aumento do volume de internações; se na forma de pagamento global por pessoa atendida, ao contrário, incentiva a redução do número de procedimentos médicos, o mesmo acontecendo na forma de pré-pagamento per capita, cuja rentabilidade está na dependência da contenção dos gastos. Nesse último caso, medidas preventivas são também incentivadas, o mesmo não ocorrendo se a lógica mercantil é a realização de procedimentos médicos. Regras diferentes produziram comportamentos diferentes entre os atores privados e teriam conseqüências no volume e, possivelmente, na qualidade da assistência prestada, sendo diferenciadas entre os segmentos que conformam a estrutura previdenciária de prestação de serviços de saúde.

Ao se diferenciar internamente, o ‘complexo previdenciário' propiciou também uma diferenciação da assistência, de modo que ao movimento no sentido da universalização da cobertura corresponde a segmentação de clientelas, tanto por tipo de financiamento dos serviços médicos - empresa, INPS ou ambos - quanto pela forma de pagamento de serviços - US, pagamento 
global, convênio bi (empresa empregadora/empresa médica) ou tripartite (empresa/empresa médica/Previdência Social). Em suma, os arranjos organizacionais estabelecidos delinearam a forma de articulação entre Estado, usuários e mercado na provisão dos serviços de saúde.

É possível concluir que a política de saúde favoreceu a expansão do mercado privado de saúde de duas maneiras: a primeira, ao tornar o setor público o maior comprador de serviços médicos, propiciando o desenvolvimento da rede prestadora privada nas décadas de 60 e 70, em estreita dependência do setor público; a segunda, ao incentivar o desenvolvimento de formas privadas de assistência, vindo favorecer uma atuação autônoma dos diferentes segmentos privados, particularmente a medicina de grupo e as cooperativas médicas.

Paralelamente a essa expansão dos serviços médicos e da assistência privada, configuram e organizam-se os diferentes interesses que passam a pressionar por recursos públicos ou por medidas que atendam a seus interesses. Expressão disso é a constituição das entidades representativas dos hospitais e da medicina de grupo - os principais interesses empresariais no setor saúde nos anos 60 - quase que concomitantemente à unificação das instituições previdenciárias, que marca a definição da política de saúde de caráter privatizante, no sentido exposto. Como afirma Costa (1998: 101): “Os incentivos institucionais favoreciam a ampliação de incrementos dos gastos do subsetor saúde dentro do sistema previdenciário; portanto, nada mais esperado que a ação de interesses organizados para influenciar na decisão alocativa."

As crises de financiamento da assistência médica passam a ser um estado regular ou recorrente na Previdência Social, já usualmente abalada por crises estruturais e/ou conjunturais, mas que são aprofundadas pelo crescimento da assistência médica, a ponto de, nos anos 80 , ganharem força propostas alternativas para a política de saúde na conjuntura de democratização do país. Entretanto, o modelo estabelecido previamente já contribuíra decisivamente para a estruturação do processo político e modelara uma determinada trajetória, de forma que foi causando constrangimentos para o desenvolvimento institucional subseqüente.

Este capítulo, portanto, tratou de mostrar as escolhas feitas em um determinado momento que configuraram um modelo de assistência à saúde cujos efeitos institucionais se farão sentir ao longo da trajetória da política de saúde. 
Tais escolhas se impuseram sobre outras alternativas que não lograram ser bem sucedidas nesse período, mas lançaram as bases para outras escolhas posteriores.

Esse quadro delineado até aqui permitirá iluminar a compreensão dos processos decisórios mais recentes. No próximo capítulo será desenvolvido o processo de constituição dos agentes privados, seus interesses e estratégias, em sua relação com as decisões governamentais e com as não-decisões. $\mathrm{Ou}$ seja: como as políticas de saúde favoreceram a formação de atores, configuraram em parte os seus interesses, definiram suas estratégias políticas e propiciaram o desenvolvimento de determinados comportamentos difíceis de serem modificados. 


\section{3}

\section{As Formas Privadas de Assistência à Saúde: desenvolvimento e características}

Nos anos 80, ocorreu uma expansão significativa das formas privadas de assistência, de modo que, no final da década, o setor privado encontrava-se consolidado e bastante vigoroso. Este capítulo focaliza o movimento de gênese e expansão dessas formas privadas, procurando elucidar alguns dos mecanismos por meio dos quais a política de saúde favoreceu o desenvolvimento da assistência privada. Nesse processo, constituíram-se atores e interesses e institucionalizaram-se determinados comportamentos e práticas, como os efeitos lock-in das políticas de saúde.

Do ponto de vista analítico, o objetivo que fundamenta o capítulo consiste em captar a constituição de atores e interesses privados, em muitos casos como conseqüência direta das decisões governamentais e em outros como contraponto a não-decisões, particularmente a ausência de regulamentação das atividades privadas autônomas. Os incentivos públicos propiciados pela política de saúde, em um primeiro momento, e a ausência de intervenção, em um segundo, favoreceram investimentos privados na área da saúde, criando diferentes organizações para a prestação de assistência médica, e como conseqüência levaram à constituição de determinados padrões de comportamento dificilmente modificados. Valendo-se do formato institucional que a assistência vai adquirindo, não apenas se constituem atores, mas estes desenvolvem atividades e realizam investimentos, ao mesmo tempo que se configuram interesses que comporão a arena política do setor em que se darão as disputas relativas às decisões governamentais em um quadro de carências de recursos 
públicos. Isso significa que as políticas de saúde não apenas estruturaram os interesses, mas também passaram a modelar as estratégias políticas dos grupos beneficiados por elas, buscando ampliar os incentivos ou manter o estado de coisas que lhes seja favorável, agindo com base no referencial das políticas públicas. Além de condicionar dessa maneira o processo político, o desenvolvimento da assistência privada, vis-à-vis à pública, têm efeitos cognitivos ou de aprendizagem que, por um lado, geram valorização das soluções adotadas e, por outro, inviabilizam a percepção de alternativas diferentes. Esses efeitos não são observados apenas entre os segmentos empresariais do setor saúde, mas também entre a sua clientela e o próprio governo. Os trabalhadores cobertos por planos de saúde privados tendem a valorizar mais a assistência privada e o governo e a readotar as soluções previamente escolhidas que priorizaram as opções privadas, além de não desenvolver capacidades próprias que permitiriam soluções alternativas quanto às formas de concessão de assistência à saúde. Como conseqüência do desenho institucional da assistência e do mau desempenho do setor público, desenvolveram-se atitudes que reforçam as opções segmentadas e valorizam a atenção privada, garantindo assim baixo suporte ao sistema público por parte dos usuários de serviços de saúde.

Esse encadeamento de efeitos das políticas de saúde reforça o argumento de que, desde sua constituição, a assistência à saúde se deu de forma segmentada, não se consolidando ao longo de sua trajetória uma proposta efetivamente universalista e igualitária, em razão mesmo de seu aprisionamento às decisões prévias.

Tal argumento difere em grande parte das explicações que podem ser identificadas na escassa literatura que trata da expansão do sistema supletivo de assistência à saúde, particularmente na década de 80, que costumam atribuí-la a um efeito inesperado do processo de expansão de cobertura da assistência pública ou como a demonstração do fracasso do Sistema Único de Saúde, criado com o objetivo de garantir o acesso universal. ${ }^{65}$ Como efeito inespera-

$\overline{65}$ A ampla produção bibliográfica sobre o desenvolvimento do sistema público de atenção à saúde não encontra correspondência em estudos mais recentes específicos do segmento privado e, principalmente, sobre suas articulações com o setor público, o que tinha sido um tema bastante relevante nas décadas de 70 e 80 , quando se discutiu amplamente o crescimento do 'empresariamento' da medicina como conseqüência das políticas públicas previdenciárias de favorecimento do setor privado. Como exceções, cabe destacar estudos pioneiros de Médici, como primeiras tentativas de descrever e mensurar o segmento privado, elaborados no início da década de 90, alguns como parte de uma série de publicações da OPS/OMS, além de artigos 
do, a expansão concomitante do segmento privado é sugerida como um processo de reestratificação da assistência médica que supostamente se buscara romper mediante mudanças na política de saúde do mesmo período, as quais visavam fortalecer o setor público e culminaram na criação do SUS.

O ponto de partida deste estudo apóia-se na hipótese da continuidade como conseqüência da dependência de trajetória, o qual contraria a idéia de que o desenvolvimento da assistência privada ocorreu como um efeito inesperado da constituição de um sistema público de cobertura abrangente. Entretanto, isso não quer dizer que os diferentes fatores explicativos arrolados na literatura para explicar a expansão efetiva nos anos 80 se excluam ou sejam incompatíveis com o argumento que se procurou sustentar. Ao contrário, esses fatores se articulam e ganham sentido com a compreensão da própria trajetória histórica da assistência, não sendo devidamente inteligíveis de forma isolada.

Entre os principais fatores explicativos identificados na literatura para a expansão da assistência à saúde supletiva está a baixa qualidade dos serviços de saúde, atribuída à ausência de expansão da rede de serviços na mesma velocidade da ampliação da cobertura (Faveret \& Oliveira, 1990; Médici, 1990, 1991a) ou à não-incorporação de recursos proporcionalmente à incorporação de novos usuários (Mendes, 1993). Por sua vez, essa insuficiência de recursos está vinculada tanto à crise financeira da Previdência Social, agudizada nos anos 80 , quanto à crise financeira do Estado que coincidiu com o momento de implantação do Sistema Único de Saúde nos anos 90. Essa situação imprimiria à universalização do acesso aos serviços de saúde o caráter excludente, ao ter como contrapartida a 'exclusão' do sistema público de grupos sociais, sobretudo das camadas médias, nas quais se incluem os setores mais organizados e com maior capacidade reivindicativa. Isso enfraqueceria as bases de apoio do

esparsos (Almeida, 1998; Pereira, Costa \& Giovanela, 2001), dissertações e teses, particularmente as de Bahia (1991, 1999). Sua tese de doutorado é bastante relevante para o tema, sendo que a autora, após uma 'garimpagem' dos dados então disponíveis, constrói um quadro do segmento privado. Digno de nota é um artigo de Faveret e Oliveira (1990), cujas hipóteses e explicações para o fenômeno de crescimento do setor privado, paralelamente à implantação de um sistema público que se pretendia universal, tornaram-se uma referência relevante e foram bastante disseminadas na bibliografia setorial, particularmente a noção de 'universalização excludente', adotada, entre outros, por Mendes (1993, 1996, 2001). Recentemente, a Agência Nacional de Saúde Suplementar (2002) publicou uma coletânea de artigos sobre o tema, produzidos em parceria com centros de produção acadêmica. 
SUS, embora pudesse ser funcional ao evitar pressões explosivas sobre o setor público (Faveret \& Oliveira, 1990). ${ }^{66}$

Bahia (1999), de forma consistente, contesta essa relação causal entre a piora dos serviços públicos e o crescimento do segmento privado nos anos 80 , uma vez que antes disso grande contingente de pessoas já estava vinculado a planos privados de saúde ou a regimes especiais de proteção social, como os sistemas de assistência médico-hospitalar para trabalhadores de empresas estatais, grandes empresas multinacionais e funcionários públicos de determinados órgãos das esferas federal, estadual e municipal. Esses mecanismos de provimento de serviços de saúde diferenciados da Previdência Social foram acionados ao longo da instituição de sistemas de proteção social mais abrangentes e se ampliaram após a unificação das instituições previdenciárias no INPS. A grande publicização do tema nos anos 80 estaria associada ao crescimento real dos planos de saúde privados, a partir dos convênios de empresas com grupos médicos sem participação da previdência, e da comercialização autônoma de planos de saúde. Para isso, teria concorrido tanto a possibilidade de migração de clientes que pagavam diretamente os provedores de serviços para planos e seguros de saúde quanto a expansão de cobertura de planos empresariais para trabalhadores do setor de serviços e para fora do eixo Sul-Sudeste. ${ }^{67}$

66 Essa exclusão se daria por 'mecanismos de racionamento', entendidos como os impedimentos ao acesso rápido ao sistema de saúde, como filas, demora para marcação de consultas médicas e cirurgias, que caracterizaram a assistência pública de forma acentuada nesse período. A idéia de exclusão sugere que alguns segmentos sociais migraram para o setor privado em razão da piora da qualidade dos serviços públicos, o que supõe, em termos lógicos, que anteriormente eles seriam cobertos pelo sistema público e que esse era de qualidade. Mas a própria análise de Favaret e Oliveira mostra a divisão anterior do sistema de saúde em dois espaços, o público e o privado, que apenas se tornam autônomos a partir dos anos $80 \mathrm{em}$ termos financeiros e em sua lógica de expansão e articulação com as clientelas. Isso significa que de fato não se pode dizer que houve uma exclusão, mas a não-incorporação desses segmentos ao sistema público, caracterizando-se, desde o início das políticas de assistência à saúde, como um sistema segmentado. Segundo as evidências, os mecanismos financeiros que possibilitaram a ampliação dos planos privados, associados ao encarecimento da assistência médica, de fato teriam expulsado os segmentos de renda mais alta da medicina liberal para os planos e seguros privados.

67 Também Levcovitz (1997, apud Bahia, 1999) questiona a hipótese de que o crescimento dos planos de saúde sejam conseqüências inesperadas das políticas reformistas dos anos 80 e mostra que a medicina supletiva autônoma já estava plenamente consolidada na década de 70 . Afinado com o esquema analítico defendido neste trabalho, destaca como a evolução da política de saúde é marcada por continuidades e rupturas - ao mesmo tempo que aconteceram mudanças nos padrões da assistência com o SUS, não houve uma ruptura com os padrões anteriores, sendo que o aumento da cobertura por planos privados vai se constituir como um limite para o projeto universalizante da reforma sanitária. É também na perspectiva da continuidade que podemos situar o pressuposto de Bahia, segundo a qual "os planos e seguros saúde integram um sistema de proteção social híbrido no qual as políticas de caráter universalista convivem com alternativas assistenciais particulares organizadas a partir das empresas empregadoras" (Bahia, 1999: i). 
Além da crise financeira do Estado, outro fator estrutural identificado para explicar a segmentação da assistência à saúde é a grande desigualdade social que obstruiria qualquer mudança na política de saúde no sentido da igualdade substantiva, implícita na noção de direito à saúde. Nessa perspectiva, a intenção universal redistributiva, expressa na legislação, se chocaria com a tendência estrutural que encaminharia o modelo brasileiro para um padrão residual, derrotando as 'utopias redistributivas' da reforma sanitária, mesmo sem nenhuma alteração no quadro legal (Faveret \& Oliveira, 1990; Médici, 1991b; Bahia, 1999). Esse caráter residual do sistema de saúde expressaria uma tensão reiterada entre um projeto de universalização do acesso e outro de caráter conservador, com ênfase na privatização, descentralização e focalização como marcas da política de saúde nos anos 80 , em consonância com o contexto de mudanças nas políticas econômico-sociais caracterizadas pela valorização do mercado em detrimento da atuação estatal (Mendes, 1993).

Secundariamente, é possível identificar a consideração de alguns fatores que poderiam ser chamados de 'institucionais', como a origem previdencialista, baseada no seguro social, do modelo de atenção à saúde no Brasil, o qual configuraria historicamente o caráter segmentado da prestação de serviços de saúde; e a existência de um sólido setor privado de oferta de serviços como conseqüência da opção governamental pela compra de serviços privados em detrimento da expansão da rede pública, o que favoreceu a constituição e o desenvolvimento de instituições privadas. A existência de um setor privado prestador de serviços bastante sólido resistiria a qualquer possibilidade de desmonte visando ao fortalecimento do setor público, embora isso fosse fundamental para a expansão da assistência à saúde de caráter universal (Médici, 1991b).

Fatores inerentes ao setor privado também são considerados para a explicação da assistência supletiva, dado que o setor desenvolveu estratégias agressivas de ampliação de seus mercados (Faveret \& Oliveira, 1990; Bahia, 1999). A qualidade insatisfatória dos serviços públicos, associada a uma ação eficiente das empresas de saúde, propiciou a expansão de novos mecanismos financeiros, que viabilizaram o acesso de amplas camadas populacionais ao sistema privado, incluindo os setores médios, como alguns segmentos de baixa renda de grandes empresas públicas e privadas. 
Por último, mas não de menor importância, algumas análises destacam fatores políticos, como a ausência de suporte efetivo ao sistema público, tanto pelo modelo de 'reforma pelo alto', que caracterizou a reforma sanitária, implementada sem o apoio efetivo dos setores organizados dos trabalhadores e de setores populares, quanto pelas estratégias particularistas de demandas dos trabalhadores com maior poder de barganha, que passam a incorporar nas suas reivindicações a entrada no sistema de atenção médica supletiva (Costa, 1995; Mendes, 1993).

Grande parte desses fatores é considerada na análise da evolução da assistência privada feita neste capítulo. Sem pretender desmontar essas explicações voltadas particularmente para a compreensão da expansão do segmento privado nos anos 80 , busca-se aqui fazer uma releitura delas e articulá-las em uma perspectiva institucionalista e histórica, a partir da qual grande parte desses fatores explicativos é vista como efeitos da dependência de trajetória.

Com o objetivo de identificar os atores e os interesses e de demonstrar como uma trajetória particular foi aprisionada em razão dos seus efeitos sobre os comportamentos de atores e organizações privadas, este capítulo tem um caráter também descritivo, de forma a produzir um quadro do mercado de assistência privada no país, incluindo as suas dimensões, diversidade e regras de funcionamento. Isso parece fundamental para entender o processo político subseqüente e a trajetória das políticas de assistência, particularmente os processos mais recentes. Na elaboração do capítulo, buscou-se então identificar a origem da assistência privada, nas suas formas iniciais, independentes da Previdência Social, mas analisando especificamente sua expansão de forma vinculada à assistência estatal e a partir dos incentivos governamentais durante as décadas de 60 e 70, e sua subseqüente autonomização em relação ao setor público, embora ainda contando com incentivos indiretos a partir da década de 80. Na sua evolução, foram se constituindo diferentes segmentos ou modalidades organizacionais e, correlatamente, diferentes interesses, cuja diferenciação, caracterização e mensuração permitem identificar a arena da saúde. A cada segmento corresponde uma diferente organização de interesses que refletem as assimetrias de poder associadas às decisões públicas relativas à alocação de recursos e a incentivos em conjunturas diversas. De fato, o que se denomina hoje de assistência médico-hospitalar supletiva, em clara alusão à idéia de ser 
suplementar à assistência pública - isto é, uma alternativa opcional e desvinculada da assistência pública de caráter universal - ${ }^{68}$ apresenta uma grande diversidade interna, sendo que cada subsegmento conformou trajetórias, em grande medida, específicas, embora se entrecruzando de diferentes maneiras. A gênese e o desenvolvimento desses segmentos mostram, desde o início da constituição da assistência médica no Brasil, a institucionalização de um sistema segmentado e diferenciado de acordo com a clientela e a configuração jurídica da instituição responsável pela atenção médica.

Se a literatura sobre a assistência privada é escassa, os dados disponíveis também são poucos e inconsistentes, produzidos, em sua maioria, por empresas de consultoria ou pelas próprias empresas operadoras de planos de saúde. Com a regulamentação recente da assistência supletiva, iniciada em 1998, abremse perspectivas para a produção de informações mais confiáveis e regulares. Este capítulo buscou consolidar as informações divulgadas na literatura disponível, além de atualizar os dados com base em levantamentos nas instituições públicas, nas entidades representativas das operadoras e/ou por meio de entrevistas com alguns de seus representantes. Os dados, em sua grande maioria, são ainda bastante precários e apenas indicativos. Mas na ausência de informações mais completas e confiáveis, foram considerados, na tentativa de esboçar um quadro geral do setor.

\section{A Trajetória das Formas Privadas de Assistência à Saúde: das origens à década de 80}

Como vimos, grande parte do segmento privado de assistência à saúde, especificamente o setor prestador de serviços, cresceu à sombra das políticas públicas, favorecido por incentivos financeiros e pela garantia de mercados cativos pela via do financiamento público. Mas outros setores tiveram seu desenvolvimento autônomo, alguns antes mesmo de qualquer política de assistência à saúde de caráter público e, possivelmente, em decorrência dessa carência de ação estatal. Além disso, os segmentos que se desenvolveram depen-

68 A idéia de um sistema suplementar se distingue de um complementar, entendido este último como algo que complementasse o sistema público. 
dentes do setor governamental via Previdência Social, particularmente durante a década de 70, adquiriram crescente autonomia em relação ao Estado na década de 80, em cujo final registra-se expressivo aumento da atividade privada sem financiamento público direto, na forma de convênio/empresa sem a intermediação da Previdência Social ou de seguro-saúde individual. Assim, o segmento privado de assistência médica não constitui algo unívoco, apresentando diferentes componentes ou subsegmentos, cuja gênese e expansão se deram em diferentes momentos e receberam diferentes classificações. A mais usual é a difundida por Mendes (1996, 2001), com base na identificação do sistema de saúde brasileiro como um sistema plural, composto por três subsistemas: o público; o de desembolso direto; e o de assistência médica supletiva. Os dois últimos fazem parte da assistência médica privada, e o desembolso direto refere-se àquela situação em que indivíduos e famílias pagam diretamente os serviços de saúde utilizados e se vincula à medicina tipicamente liberal. ${ }^{69} \mathrm{~A}$ assistência supletiva, por sua vez, é composta por cinco 'modalidades assistenciais': medicina de grupo; seguro-saúde; cooperativas médicas; sistemas próprios de empresas (os sistemas de autogestão); e planos de administração. As duas últimas modalidades referem-se apenas à assistência médica organizada pelas empresas empregadoras, e as demais podem ter como clientes tanto empresas quanto indivíduos e famílias, estes últimos em número bem menor. ${ }^{70}$ Bahia (1999), atendo-se apenas às alternativas assistenciais particulares organizadas a partir das empresas empregadoras e considerando as mesmas alternativas empiricamente observáveis, elabora uma tipologia com base nas formas de gestão dos riscos com despesas médico-hospitalares e distingue duas alternativas para a gestão de risco: a mutualista, na qual há retenção do risco pelas empresas empregadoras, usualmente denominada de autogestão; e

69 A Pnad/1998 revelou um número significativo de pessoas que não são cobertas por planos privados de saúde, mas que também não são usuárias do SUS, inferindo-se daí que utilizam serviços de saúde por meio do desembolso direto. Em relação à assistência odontológica, mais de $50 \%$ das pessoas pagam por esses serviços. Entre todas as pessoas que tinham tido atendimentos variados de saúde no período de 15 dias anterior à pesquisa, cerca de $16 \%$ tinham pago por esse atendimento; e uma proporção pequena de atendimentos feitos pelo SUS também implicou algum gasto.

70 “(...) ficou consagrada no Brasil uma divisão jurídico-institucional dos planos privados de saúde: medicina de grupo, cooperativas médicas, seguradoras e autogestão. Os termos comumente usados para designar este segmento têm sido 'saúde suplementar, assistência médica suplementar, atenção médica supletiva ou assistência médica complementar”' (Ciefas, 2000: 23). 
a securitária, que implica a contratação de empresas especializadas para a gestão de riscos pelas empresas empregadoras. Cada uma dessas alternativas comporta diferentes formatos institucionais. A forma mutualista pode ser associativa-sindical, no caso em que entidades de trabalhadores organizam instâncias independentes das empresas empregadoras para gerir a assistência; ou organizada diretamente pela empresa empregadora. A alternativa securitária, por sua vez, pode assumir o formato de medicina de grupo, cooperativa médica ou seguradora. ${ }^{71}$

Empiricamente, a assistência médica supletiva de maior relevância em termos quantitativos é aquela prestada a partir de iniciativa das empresas empregadoras. Historicamente, a assistência privada tem origem nessas empresas. Ainda hoje os planos coletivos predominam no Brasil, cobrindo cerca de $72 \%$ do total de beneficiários de planos privados de saúde (ANS, dez. 2006). Essa preponderância é um importante efeito de feedback das políticas de saúde e caracteriza a assistência privada como um benefício vinculado às relações de trabalho. Mesmo que esses planos coletivos tendam a se concentrar nos setores mais dinâmicos da economia, em que também os salários costumam ser maiores, o acesso a essa assistência empresarial não está diretamente vinculado à disponibilidade de renda. A incorporação de indivíduos e famílias, anteriormente usuários da assistência pública ou da medicina liberal, às empresas médicas e seguradoras por meio da aquisição de planos e seguros de saúde é bem mais recente e de dimensões bem menores. Essa forma de acesso à assistência privada está diretamente vinculada à disponibilidade de recursos financeiros e engendra uma relação tipicamente de consumo por meio da qual, dependendo do produto adquirido e discriminado em um contrato, adquire-se o direito a um pacote de serviços de saúde.

As origens das diferentes modalidades institucionais de assistência médica de caráter privado apresentam diferenciações no tempo e nas características,

71 A empresa de consultoria em gerenciamento e recursos humanos Towers Perrin, que desde 1981 realiza anualmente pesquisa sobre planos de benefícios em uma amostra de empresas do Brasil, distingue dois regimes de concessão dos sistemas de assistência médica e hospitalar das empresas: segurado e auto-segurado. Os planos segurados são aqueles em que a empresa prestadora assume o risco em troca de um pré-pagamento mensal por parte da empresa tomadora; eles se viabilizam por meio da medicina de grupo, cooperativas médicas ou seguro-saúde. O plano auto-segurado é aquele em que a empresa tomadora assume o risco, pagando pelos serviços efetivamente utilizados, e se viabiliza por meio da administração própria (autogestão) ou de administração de terceiros (Towers Perrin, 1997). 
embora todas as modalidades compartilhem muitos aspectos. Historicamente, desde o final do século XIX existiam organizações mutualistas de caráter voluntário para garantir alguns auxílios, entre eles alguns benefícios médicos, aos seus associados. Durante a República Velha elas se expandiram não apenas entre os estratos médios, mas também entre os trabalhadores (Bahia, 1999; Médici; 1990; Menicucci, 1990; Oliveira \& Teixeira, 1984, 1986).

A partir dessa mesma época, também algumas empresas propiciavam assistência médica aos seus empregados, sendo que uma das formas privadas de organização dos serviços de saúde consideradas mais antigas são as originadas nas empresas por intermédio de seus departamentos de recursos humanos, ou de suas caixas ou associações de funcionários, ou de sindicatos. No primeiro caso, a própria empresa administrava a assistência; no segundo, a partir de associações de empregados, estimuladas pela empresas, eram criadas entidades jurídicas paralelas às empresas, denominadas de 'caixas' (Bahia, 1999). De acordo com investigações anuais do Departamento Estadual do Trabalho, entre 1911 e 1919, das trinta fábricas pesquisadas em São Paulo, cerca de metade já fornecia serviços médicos, embora parte dos custos de tais serviços fosse transferida para os próprios trabalhadores, com um desconto que correspondia a cerca de 2\% dos salários (Possas apud Carneiro, 2001). Com o desenvolvimento da indústria, os serviços médicos de empresas tornaram-se mais numerosos, sendo que a preocupação principal estava voltada para a saúde ocupacional e para a medicina do trabalho em seus aspectos preventivos e assistenciais.

A partir dos anos 40, desenvolvem-se essas formas de prestação de serviços de saúde, particularmente no âmbito de empresas estatais e multinacionais, bem como em algumas instituições públicas, concomitantemente à expansão dos IAPs e de forma complementar aos serviços de saúde de caráter público. Exemplos importantes desses planos de assistência privados restritos a determinadas clientelas no âmbito de empresas ou instituições públicas são a Caixa de Assistência à Saúde dos Funcionários do Banco do Brasil (Cassi) e a Assistência Patronal (atualmente Geap), inicialmente restrita aos funcionários das instituições previdenciárias e depois ampliada para outras categorias de servidores públicos. Como expressão do movimento contraditório de expansão/ seletividade da assistência médica, na mesma época foi construído um Hospi- 
tal do Instituto de Aposentadorias e Pensões dos Bancários (IAPB) para atender toda a categoria dos bancários e um hospital exclusivo para trabalhadores da Companhia Siderúrgica Nacional.

A Cassi foi criada em 1944 por um grupo de funcionários do Banco do Brasil lotados em cidades do interior, com a finalidade de ressarcir as despesas médicas de seus associados e dependentes, sob a alegação de que o IAPB instituto dos bancários - não oferecia atendimento em muitas cidades do interior, de forma que esses funcionários não gozavam da mesma assistência de qualidade que existia nas capitais. Idealizada e administrada por empregados da ativa, em 1962 a Cassi passou a admitir como associados aposentados e pensionistas. Após a fusão dos IAPs, com a criação do INPS, em 1967, houve 'uma corrida' dos funcionários do banco para a Cassi como alternativa ao atendimento público, uma vez que a unificação das instituições previdenciárias significou uma diminuição da qualidade em relação ao IAPB, considerado o mais pródigo dos institutos. Esse crescimento obrigou a reestruturação da Cassi em 1970, quando passou a ser mantenedora da assistência à saúde do Banco do Brasil. Em 1973, a filiação tornou-se obrigatória, com os funcionários contribuindo com 1\% de seus salários e o banco com 2\% (Carneiro, 2001; Ciefas, 2000).

Apenas um ano antes da Cassi, foi criada a Assistência Patronal, atualmente Geap-Fundação de Seguridade Social. A denominação original da Geap, diferentemente da Cassi, mostra que o seu surgimento se deve a uma iniciativa patronal, e sua história é indicativa da dinâmica da segmentação da assistência médica no Brasil. Ela surge no âmbito do IAPI para prestar assistência médica diferenciada aos servidores de um instituto que se caracterizava por ser dos mais restritos em termos de benefícios assistenciais e cujos dirigentes, de grande influência na história da previdência no Brasil, defendiam a idéia de que ela deveria se limitar aos benefícios previdenciários. Demonstrando uma posição bastante elitista e corporativa, entretanto, esses mesmos atores implantaram uma assistência médica diferenciada para os 'patrões' da instituição previdenciária, que deveria se distinguir daquela prestada ao segurado comum - "gente mais simples", conforme depoimento colhido para a reconstituição da história da Patronal (Menicucci, 1987: 9). Entretanto, para os industriários a assistência médica só seria concedida pelo IAPI nos anos 50, após intensa pressão dos associados e, particularmente, do governo federal, mesmo assim de forma 
bastante incipiente. Documentos colhidos na mesma pesquisa justificam a criação da Patronal com base em argumentos similares às justificativas empresariais então utilizadas para a prestação de assistência aos empregados: facultar aos servidores meios necessários à manutenção do grau de produtividade indispensável ao eficiente desempenho de seus encargos; proporcionar melhores condições de atendimento médico-hospitalar, visando a uma recuperação mais rápida, beneficiando, assim, a própria instituição; e implantar novas técnicas de organização do trabalho, a exemplo do que já ocorria em numerosas empresas privadas. Após a unificação dos IAPs, a Patronal se estendeu para todos os funcionários do novo INPS, e a cada alteração institucional da Previdência Social - em geral significando ampliação de segurados no sentido de universalização da cobertura - iam se ampliando seus beneficiários, em um movimento contrário de diferenciação da assistência para a burocracia previdenciária. Na década de 90, após se transformar na Geap-Fundação de Seguridade Social, assumindo a personalidade jurídica de uma entidade fechada de previdência privada, passou a incorporar outras categorias de funcionários públicos. Em outubro de 2001, contava com 718.700 beneficiários, originados de 21 órgãos públicos, mantendo, entretanto, a característica de ser uma assistência privada voltada principalmente para as pessoas encarregadas da gestão do sistema de saúde público, uma vez que 43,28\% do total de clientes são provenientes do Ministério da Saúde (Geap, 2002).

Outra experiência de sistema de autogestão de assistência à saúde e previdência com características diferenciadas foi a criação, em 1957, do Serviço de Assistência e Seguro Social dos Economiários (Sasse), destinado à prestação de serviços assistenciais e previdenciários aos funcionários da Caixa Econômica Federal, desvinculando-os do IAPB (Carneiro, 2001).

Nas empresas estatais, desenvolvidas principalmente nos anos 70, a assistência médica passou a constar entre os benefícios oferecidos aos empregados. No setor privado, a assistência no âmbito das empresas acompanhou a instalação da indústria automobilística, particularmente das montadoras estrangeiras, a partir dos anos 50 (Ciefas, 2000; Bahia \& Vianna, 2002; Abramge, 2002).

Em meados da década de 60, a assistência diferenciada no âmbito de empresas, restrita aos seus empregados, foi estimulada pelas políticas públicas, com a introdução do convênio-empresa, que garantia um subsídio governa- 
mental para o custeio dessa assistência anteriormente financiada pela empresa. Essa opção governamental reforçou e ampliou consideravelmente uma prática empresarial que existia ainda de forma restrita desde as décadas anteriores. O convênio-empresa foi o incentivo dado pelo governo para a diferenciação dos padrões de assistência à saúde e contribuiu para o crescimento e a consolidação do sistema supletivo de saúde para as grandes empresas. O nivelamento dos benefícios e a ampliação substantiva da demanda com a criação do INPS, que se traduzia em uma pressão sobre a oferta de serviços e tinha repercussões na qualidade da assistência prestada, representaram a justificativa para a expansão da assistência empresarial nas grandes empresas públicas e privadas, particularmente as localizadas na região Sudeste. Isso significa que ao movimento de ampliação de cobertura em direção à universalização que representou a reforma previdenciária contrapunham-se outras medidas públicas que recriavam a diferenciação entre os trabalhadores em relação à assistência, desta vez não mais por categoria profissional, como era a característica dos IAPs, mas pela forma de inserção no mercado de trabalho.

Da mesma forma que a ausência de um projeto universalista e igualitário caracterizou a inserção de forma corporativa dos benefícios sociais no Brasil, entre eles a assistência à saúde, a unificação das instituições previdenciárias, com a conseqüente unificação de benefícios e serviços, não significou a constituição de um projeto político de diretos igualitários. A reforma foi feita de cima para baixo pelo governo autoritário, sem expressar uma demanda coletiva ou sem a mobilização de trabalhadores nesse sentido. Ao contrário, as propostas reformistas anteriores contaram com as pressões corporativas que se opunham à unificação. É logicamente plausível supor que a expansão da assistência empresarial privada, incentivada pela política governamental, tenha tido o efeito de reforçar muito mais uma 'cultura' da diferenciação, passando a vincular o interesse imediato de uma parcela de trabalhadores a uma assistência privada de melhor qualidade.

A motivação das empresas para assumir a assistência de seus empregados está relacionada a diferentes fatores, entre os quais: a importância da saúde para a produtividade, que passou a ser um elemento fundamental no tipo de indústria implantado no final da década de 50; e a necessidade de controlar o absenteísmo, comprometido pelas dificuldades de acesso ao atendimento 
público, particularmente o ambulatorial, situação que causava atraso na solução dos problemas de saúde dos empregados. Às empresas interessava ter sob seu controle a assistência médica de seus empregados para obter uma solução mais rápida na recuperação das condições de trabalho e para o acompanhamento do índice de absenteísmo (Carneiro, 2001). A cobertura assistencial das empresas enfocava mais os trabalhadores do que seus familiares e, em geral, limitava-se aos atendimentos ambulatoriais. Essa 'medicina do trabalho' era voltada para a prevenção das doenças ocupacionais e dos acidentes do trabalho, para a redução das perdas daí decorrentes e, também, para a promoção de melhor adequação do empregado ao processo de produção. A utilização dos serviços de saúde como instrumento de controle dos empregados e a perda do direito de utilização do INPS causavam a resistência dos sindicatos aos convênios com a Previdência.

Com os incentivos financeiros propiciados às empresas que montassem serviços de saúde, desenvolveram-se os serviços próprios de empresa ou planos de autogestão, casos em que a própria empresa administra a assistência médica prestada a seus empregados. Como visto no capítulo anterior, em alguns casos a empresa passou a optar pela contratação de outra empresa para gerir a assistência médica, dando impulso à medicina de grupo e, em um segundo momento, às cooperativas médicas, como reação à medicina de grupo. Nessas situações, a empresa empregadora paga para a empresa ou cooperativa contratada um valor per capita prefixado, independentemente dos procedimentos que venham a ser executados, dando origem aos chamados 'planos de pré-pagamento'. Apenas mais tarde as empresas passaram a optar também pela contratação de um seguro de saúde, em vez de administrarem seus planos. A expansão da assistência empresarial assumiu, assim, diferentes formatos institucionais e propiciou a constituição de novos agentes no mercado da assistência privada, configurando identidades e clivagens sociais.

Embora a formação da medicina de grupo tenha se iniciado na década de 50 , quando se constitui o primeiro grupo médico, ${ }^{72}$ seu desenvolvimento ocorreu na década seguinte, quando surgiram algumas das maiores empresas

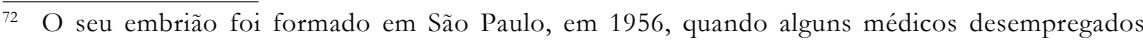
uniram-se para dar assistência aos funcionários e familiares de uma empresa em expansão, mediante um pré-pagamento fixo" (Abramge, 2002). 
em razão da articulação entre grupos de médicos com hospitais privados ou filantrópicos que ofereciam serviços mediante pré-pagamento (Bahia, 1999). Seu surgimento está associado diretamente à assistência médica empresarial, uma vez que as empresas de medicina de grupo eram voltadas exclusivamente para as empresas que mantinham assistência para seus empregados, mediante o sistema de convênios, pelo qual eram comercializados os chamados 'planos coletivos, ou empresariais'. Os primeiros convênios foram realizados em São Paulo, onde, desde então, concentrou-se a maior parte da clientela das empresas de medicina de grupo, que se expandiria principalmente nas capitais, em razão da concentração de empresas de médio e grande portes, nas quais há maior possibilidade da oferta de planos assistenciais para os empregados. ${ }^{73}$

A explicação dada pelo próprio setor para esse desenvolvimento na década de 60 remete, por um lado, ao desenvolvimento industrial do período, particularmente com a instalação da indústria automobilística no $\mathrm{ABC}$ paulista, com o correspondente crescimento das demandas por serviços de saúde da classe trabalhadora, associado à precariedade dos serviços públicos na região, que não conseguiam atender à demanda crescente; e, por outro lado, ao alto e crescente custo da medicina liberal, em razão do desenvolvimento tecnológico. A medicina de grupo apresentou-se como uma opção intermediária e alternativa, com o sistema de pré-pagamento, estimulado pelos próprios empresários.

Apesar de iniciar de forma incipiente independentemente dos convênios com a Previdência Social, esse processo de expansão da medicina de grupo e, depois, das cooperativas médicas foi altamente estimulado pelas políticas governamentais de ampliação de cobertura e incentivo à privatização dos serviços de saúde, por meio dos convênios-empresa, mediados e financiados pela Previdência Social. Para a consolidação das empresas médicas, foi importante a articulação política dos setores privados com segmentos da burocracia previdenciária, constituindo os famosos anéis burocráticos da Previdência Social, bastante favoráveis à consolidação desse modelo de expansão da assistência médica.

\footnotetext{
Em 1973, São Paulo concentrava cem dos 132 grupos médicos registrados pela Abramge, ao passo que no Rio de Janeiro atuavam apenas 11. A explicação dada por Cordeiro (1984) inclui os seguintes fatores: existência de um setor estatal com maior capacidade instalada no Rio de Janeiro; desinteresse inicial do setor industrial e de serviços do Rio de Janeiro; falta de apoio da burocracia regional aos convênios-empresa. Em compensação, o peso dos contratos individuais com a medicina de grupo seria maior no Rio de Janeiro do que em São Paulo.
} 
As cooperativas médicas surgem nos anos 60 , posteriormente à medicina de grupo e em oposição a ela, que sempre foi vista pela categoria médica como um mecanismo indesejado de aviltamento do trabalho médico e mercantilização da medicina. ${ }^{74}$ Experiência inédita, as cooperativas resultaram de um movimento de oposição aos grupos médicos, liderado pela AMB e por alguns sindicatos médicos, e foram uma estratégia para preservar a autonomia da categoria ante o que ela considera a subordinação do trabalho médico, na forma de assalariamento, à lógica lucrativa dos proprietários das empresas de medicina de grupo. Procurando sempre marcar sua especificidade, ${ }^{75}$ esse movimento se dispôs a passar para a sua responsabilidade direta a prestação de assistência médica aos trabalhadores. Em 1974, pelo Plano de Pronta Ação, a Previdência Social passou a priorizar a livre escolha e incorporou as cooperativas médicas à assistência pública.

Mas, ao contrário da medicina de grupo, a expansão inicial das cooperativas se deu com a captação de clientes individuais, espalhados por todo o país, embora a maioria fosse sediada em cidades do interior de São Paulo. Até a década de 80, os convênios com empresas eram bem mais reduzidos em relação à medicina de grupo. Entretanto, desde essa época, mesmo partindo de concepções antagônicas sobre a prática médica, passaram a disputar com a medicina de grupo a mesma clientela - as empresas que prestavam serviços de saúde a seus empregados - e adotaram os mesmos mecanismos de financiamento e controle do consumo de serviços, via sistema de pré-pagamento.

A terceira e mais recente modalidade empresarial a atuar no mercado de assistência à saúde é constituída pelas seguradoras. Apesar de o seguro de saúde estar previsto desde o decreto-lei 73/66, a comercialização de seguros no ramo saúde iniciou-se nos anos 70, após autorização da Superintendência de Seguros Privados (Susep) e em decorrência da Resolução 11 do Conselho

74 A primeira surgiu em Santos (SP), em 1967, espalhando-se por cidades paulistas e depois por todo o Brasil. É uma modalidade de assistência privada em que os médicos cooperados são também os prestadores de serviços, recebendo pagamento por capitação. Em princípio, seguem a legislação específica de cooperativas e não têm fins lucrativos.

75 "A Unimed não é uma empresa de assistência médica como as outras, é uma Cooperativa de Trabalho Médico, em que os próprios médicos cooperados são os donos do negócio. Isso garante ao médico a ética na prática de sua profissão, e ao usuário, o privilégio de ser atendido com toda a dignidade e qualidade no consultório do próprio dono" (Unimed Brasil, 2002). 
Nacional de Seguros Privados (CNSP), de maio de 1976. Seu crescimento se daria apenas nos anos 90. Para o ramo Seguro de Saúde, a legislação estabelece limite financeiro de acordo com o valor da apólice adquirida, franquia e livre escolha dos profissionais e serviços de saúde pelo segurado com pagamento direto ao prestador de serviço. Sem relação direta com o Seguro de Saúde, a Resolução CNSP 16, de 20/12/88, criou o ramo específico, denominado 'Seguro de Assistência Médica e ou Hospitalar', que se assemelha ao plano de saúde e prevê contrato com limite financeiro anual e/ou com base em tabela de valores por evento, instituindo o reembolso de despesas. O Seguro de Saúde tem baixa aceitação no mercado brasileiro e é pouco comercializado. Já o Seguro de Assistência Médica e/ou Hospitalar é o principal produto das seguradoras que atuam no ramo saúde (Mesquita, 2002). A atuação mais sistemática das seguradoras na assistência supletiva deu-se a partir de 1989, quando foram autorizadas por um dispositivo legal da Susep (Circular 5/1989) a se vincularem a serviços de saúde mediante o referenciamento de prestadores de serviços. Com isso, elas tiveram a alternativa de efetuar o pagamento direto ao prestador, em vez de se limitarem ao pagamento das despesas realizadas pelo segurado, conforme previsto na apólice. Isso permitiu a diminuição dos custos, deixando-as mais competitivas; na prática, tornou-as similares à medicina de grupo e às cooperativas ao poderem constituir redes de serviços médicos. Inicialmente voltadas para clientes individuais, passaram também a disputar o mercado das empresas, uma vez que este apresenta maiores perspectivas de expansão. Além disso, passaram a competir pela administração de planos de autogestão.

\section{A Expansão da Assistência Médica Supletiva nos Anos 80 e sua Evolução Recente}

A década de 80 registra expansão da assistência médica privada, em decorrência, principalmente, do aumento substancial dos planos empresariais de assistência à saúde. Nesse momento, essa expansão vai prescindir dos subsídios governamentais diretos que tinham sido importantes para sua institucionalização e a assistência privada já está legitimada tanto por usuários 
como pelo governo e pelas empresas. Essa consolidação se dá paralelamente a mudanças nas políticas de saúde no sentido de valorização do setor público mediante maior racionalização na utilização dos recursos em momento de crise de financiamento da assistência médica previdenciária, o que será objeto do próximo capítulo.

Embora as razões que motivaram as empresas a criar planos de saúde para seus empregados nas décadas anteriores não deixem de estar presentes, outras motivações nesse período se agregam às anteriores. Do ponto de vista da empresa, o desenvolvimento da assistência médica nos anos 80 está associado à evolução das teorias administrativas e às novas concepções relativas ao papel social da empresa, segundo as quais se passou a considerar a assistência médico-hospitalar integral e complementar também como responsabilidade da empresa, e não apenas a saúde ocupacional e a medicina do trabalho (Médici, 1991b). Sem deixar de ser um mecanismo de controle das perdas do trabalho, por meio da assistência a empresa passa a enfocar, além da medicina do trabalho, a segurança social, ocupando-se ainda da assistência médica global - abarcando atendimentos ambulatoriais, hospitalares e odontológicos - não só dos empregados, mas também de suas famílias. Os gastos com saúde assumem a conotação de investimentos, considerando que os problemas de saúde da família também interferem na produtividade. Em alguns casos, a assistência passa a cobrir até os aposentados como forma de facilitar a rotatividade da mãode-obra (Carneiro, 2001). Pesquisa feita pela empresa de consultoria Montigny Woerner, em 1989, mostrou que os fatores identificados pelas 230 empresas pesquisadas que as levavam a ter um plano de assistência médica, por ordem de importância, e não mutuamente exclusivos, eram: dar ao empregado sentido de segurança; manter a empresa competitiva em relação ao mercado; atrair e reter mão-de-obra de melhor qualidade; amenizar o clima de conflito entre patrões e empregados; cumprir bons preceitos de responsabilidade social; compensar as deficiências do sistema público; manter quadro de empregados saudáveis para reduzir absenteísmo e melhorar o desempenho; fornecer salário indireto; por motivos de saúde pública e higiene do trabalho; e por exigências dos dissídios coletivos. Apenas os três últimos fatores tiveram menos do que $80 \%$ de respostas. A mesma pesquisa mostrou que as empresas que investiam mais em atenção médica eram aquelas com 
mão-de-obra mais qualificada, melhores salários, menor rotatividade e alta incorporação de tecnologia. ${ }^{76}$

Outro condicionante para a expansão da assistência privada nos anos 80 foi a piora da qualidade dos serviços estatais, atribuída à crise da Previdência Social da primeira metade da década, em conseqüência da redução dos preços pagos ao setor privado prestador de serviços. ${ }^{77}$ Outra conseqüência da crise que atingiu diretamente o mercado de assistência à saúde foi a progressiva extinção dos convênios da Previdência Social com as empresas, realizada não de forma explícita, mas via mecanismo de remuneração, que deixa de ser o incentivo que alavancara o estabelecimento dos convênios nas duas décadas anteriores. Em 1986, o valor per capita pago pela Previdência aos convênios foi congelado, em um momento de altas taxas inflacionárias, chegando a perder seu valor real, desestimulando a manutenção dos convênios. A perda de importância dos convênios-empresa como mecanismo de financiamento público da assistência prestada pelas empresas levou a uma transformação no financiamento dos seus serviços de saúde, que passam a ser custeados pela empresa diretamente e pelos funcionários, mostrando a institucionalização desse tipo de atividade empresarial.

Outros instrumentos legais passariam a funcionar como incentivo estatal indireto para as empresas manterem planos de saúde para seus empregados. Em primeiro lugar, destacando-se pelo seu significado político, foi a permissão

76 De acordo com Carneiro (2001), a política de saúde da empresa é influenciada por vários fatores, como o porte da empresa, o modelo de regulação do trabalho, a incorporação de tecnologia, o tipo de mão-de-obra, a cultura empresarial, a organização sindical dos empregados, a atuação dos concorrentes, a localização da empresa, a legislação em vigor, a concentração do efetivo. Mas o elemento decisivo é a incapacidade do Estado para prestar assistência adequada. Empresas com mão-de-obra pouco especializada, baixos salários, alta rotatividade, produção fortemente influenciada pelo tamanho e ritmo da jornada de trabalho tenderam a investir menos, restringindo-se a atendimentos ambulatoriais, usualmente por meio da medicina de grupo. Ao contrário, empresas com mão-de-obra especializada, melhores salários, rotatividade pequena e alta incorporação de tecnologia investiram mais, buscando atenção médica de padrão melhor e mais completa.

77 A remuneração dos serviços dos prestadores tinha como referência tabelas próprias do Inamps, que era o grande comprador de serviços, as quais eram adotadas, inclusive, pelos outros compradores, como medicina de grupo e empresas. Um dos mecanismos governamentais para reequilibrar seu orçamento foi reduzir os gastos com a compra de serviços, reajustando as tabelas e a unidade de pagamento de honorários (US) abaixo dos índices inflacionários. Dados de Médici (1991c) mostram que no período de $1977 / 83$, ao passo que houve uma variação no valor do salário mínimo da ordem de $2.139 \%$, o valor da US paga pelo Inamps para remuneração dos serviços de saúde subiu apenas $1.231 \%$, e o preço da diária hospitalar em enfermaria no mesmo período aumentou apenas em $1.327 \%$. 
legal para as empresas repassarem os gastos aos preços dos produtos, computando as despesas com assistência médica como custos operacionais, sendo, portanto, objeto de dedução da renda bruta para efeitos de tributação do Imposto de Renda. ${ }^{78}$ Embora seja ainda difícil estimar o volume dessa renúncia de arrecadação, ela é indicativa do objetivo governamental de incentivar as empresas a assumirem a assistência de seus empregados, uma vez que as despesas tributárias (ou renúncias de arrecadação), em suas diferentes formas, só se justificam com vistas a se alcançar algum objetivo ou estimular alguma atividade. Podemos inferir que, por meio desse incentivo indireto, a opção pública contribuiu para a expansão da assistência médica de caráter privado no âmbito das empresas, já devidamente estruturadas para isso desde as décadas de 60 e 70, quando contaram com incentivos diretos. Além de funcionar como incentivos financeiros, a política fiscal indica a valorização por parte do Poder Público da assistência empresarial ao trabalhador, vista como uma política de cunho social, de tal forma que mesmo que esses incentivos não tenham grande expressão financeira indicam uma opção valorativa do Poder Público, acatada pela empresa e corroborada pelos trabalhadores. Nesse sentido, pode-se falar da constituição de uma 'cultura' de assistência médico-hospitalar de cunho privado e empresarial para os trabalhadores em detrimento de uma cultura publicista.

Um segundo mecanismo nos anos 80 contribuiu para favorecer o desenvolvimento da assistência médica das empresas com parte dos custos assumidos pela Previdência. Em razão de forte reação dos prestadores de serviços representados principalmente pela Federação Brasileira de Hospitais (FBH) e pela Associação Médica Brasileira (AMB) - à deterioração de sua remuneração, por meio de algumas medidas, sem aumentar os valores pagos, o governo transferiu para os usuários do sistema público o pagamento de parte do valor dos atendimentos ao permitir a cobrança de complementação para os segurados que optassem por acomodações especiais, superiores às autorizadas

78 Os dados disponíveis pela Secretaria da Receita Federal não permitem a mensuração do volume de recursos gastos pelas empresas com saúde, mas "a SRF estima que as empresas deduziram, com pagamento de assistência médica para os seus empregados, R\$2,368 milhões, em 1996, e R $\$ 2,175$ milhões, em 1998” (Dain, Quadros \& Cavalcanti, 2002: 232). 
pela Previdência Social. ${ }^{79}$ Pensadas como medidas para compensar a deterioração dos valores pagos pela Previdência aos hospitais contratados, transferindo o custo para os usuários, elas incentivaram a ampliação dos planos empresariais, uma vez que essa complementação poderia ser coberta diretamente pelos segurados ou pelo sistema de assistência médica próprio da empresa. Como conseqüência, os hospitais privados passaram a canalizar maior número de pacientes para acomodações especiais e a dificultar as internações em enfermarias - acomodação custeada pelo setor público -, direcionando sua ação para clientelas de maior poder aquisitivo e, particularmente, para os empregados de empresas com planos de saúde próprios (Médici, 1991a). ${ }^{80}$

Esse arranjo, a princípio, garantiu o equilíbrio dos vários interesses favorecidos por ele, na medida em que o governo mantinha seus gastos comprimidos, os prestadores de serviços - hospitais e profissionais - recebiam valores majorados, as empresas atendiam seus empregados a custo mais reduzido e os empregados de empresas que mantinham planos de saúde recebiam atendimento de nível mais elevado a menor custo. Para a população excluída desse arranjo, ou seja, a grande massa de segurados, a qualidade do atendimento público nos estabelecimentos privados se deteriorava, em conseqüência das estratégias de redução de custos adotadas pelos prestadores para se adaptarem aos preços pagos pelo setor público. Para aumentar o faturamento, os prestadores também agiram, tendo em vista os limites e

79 Pela portaria 2.079/1980/Inamps, o governo permitiu a cobrança de valores adicionais por instalações de padrão superior ao custeado pelo setor público, o que significou aumento de $100 \%$ dos preços das diárias e taxas hospitalares e dos honorários médicos no caso de utilização de acomodações especiais. Pela portaria MPAS 2.837/1982, foi permitida a cobrança de até 8,3\% vezes a tabela de honorários médicos elaborada pelas associações de classes para atendimentos especiais, o que aumentava em mais de $700 \%$ a complementação.

80 No início da década de 90, quando se inicia o processo de implantação do SUS, esses mecanismos foram revogados pela resolução 283/1991 do Inamps. Recentemente, em um contexto de insatisfação crescente dos profissionais médicos quanto aos critérios e tabelas de pagamento dos planos e seguros de saúde, houve tentativas de restabelecer a possibilidade de complementação de honorários aos pacientes do SUS quando optassem por acomodações especiais. Proposta do deputado federal Rafael Guerra nesse sentido, aprovada sob a forma de uma indicação ao Poder Executivo pela Comissão de Seguridade Social e Família, não foi considerada, entretanto, pelo Ministério da Saúde, o que parece confirmar a segmentação definitiva entre os pacientes do SUS e os dos planos de saúde. A proposta encontra também apoio da entidade representativa dos hospitais, interessados em aumentar os seus serviços em uma situação identificada como de crise e endividamento. 
possibilidades apresentados pelas regras estabelecidas para pagamento pelo setor público. ${ }^{81}$

Mas ao atender as entidades representativas dos prestadores e adotar como referencial as suas tabelas, a decisão do governo significou um aumento substancial do custo da complementação do atendimento, levando a um comportamento adaptativo das empresas que mantinham assistência para seus empregados. Elas passaram a dificultar as internações via serviços estatais e optaram por fazê-las mediante contratos diretos com os prestadores de serviço, com base em tabelas de remuneração, a princípio, baseadas na tabela pública e gradativamente sendo negociadas tabelas próprias com os prestadores (Carneiro, 2001). Essa mudança de comportamento marca uma inflexão importante e consolida o processo de autonomização da assistência privada prestada pelas empresas em relação à assistência pública. Iniciado com o fim dos convênios empresas-Previdência Social, esse processo se consolida e essa modalidade de assistência deixa de ser complementar à assistência pública e se torna suplementar, isto é, independente. Em reação às decisões públicas, mudaram as estratégias dos atores - hospitais e empresas.

Em conseqüência, o desenvolvimento da assistência privada passa a se mover pela lógica de um mercado auto-regulado. Em uma situação de ausên-

81 De acordo com Carneiro (2001), um participante ativo do sistema de assistência médica das empresas, tanto como administrador do plano da Usiminas quanto como dirigente da Associação de Serviços Assistenciais de Saúde Próprios de Empresas (Asaspe), para a redução dos custos os administradores hospitalares tenderam a aumentar o número de leitos por enfermarias; reduzir o número de funcionários, além de manterem um 'arrocho salarial'; reduzir investimentos em obras, serviços de manutenção e de infra-estrutura; e reduzir gastos com serviços básicos, como cozinha, lavanderia, sistemas de controle de qualidade e de infecção hospitalar. A conseqüência óbvia foi o rebaixamento geral da qualidade do atendimento em enfermarias. Para aumentar o faturamento, trataram de transformar enfermarias em apartamentos; buscar superfaturamento de materiais e medicamentos cujo pagamento observava os valores de mercado; realizar investimentos em compra de equipamentos geradores de serviços; aumentar a realização dos serviços auxiliares de diagnóstico e tratamento, direcionando os serviços hospitalares para ações de alto custo e tecnologia; e forçar a internação em apartamentos, além de realizar fraudes. A redução percentual dos ganhos com diárias, taxas e honorários foi acompanhada pelo crescimento do faturamento com materiais/medicamentos (MAT/MED) e pelos serviços auxiliares de diagnósticos e tratamentos (SADT). Ao passo que no período de 1967/76 as diárias e taxas correspondiam a $57 \%$ das receitas hospitalares, elas se reduzem para $34 \%$; o MAT/MED aumenta de $11 \%$ para $17 \%$; os honorários baixam de $15 \%$ para $9 \%$; e os SADT passam de $16 \%$ para $40 \%$ das receitas hospitalares. A incorporação de tecnologia foi utilizada como forma para tornar inócuas as tentativas do Inamps de restrição de gastos, o que foi facilitado pelo sistema de US, pois, embora fosse limitado o valor da US, não o era o seu número global. 
cia de regulação governamental, os diferentes agentes do mercado se movimentam no sentido de se auto-regulamentarem. Nesse processo, a categoria médica, por intermédio da AMB, a partir de 1984, passou a editar uma tabela de honorários médicos para todo o território nacional, voltada para reger os convênios e contratos estabelecidos entre serviços de saúde e empresas (Médici, 1991a). Isso foi o resultado de uma ação de planos de autogestão em razão de uma crise que os forçou a adotar ações conjuntas ante os prestadores de serviços para negociar preços. Em 1986, o Inamps abandonou sua própria tabela e passou a adotar a da $\mathrm{AMB}$ para pagamento dos serviços contratados e tornou livre a complementação de honorários e serviços para uso de acomodações especiais, mais uma vez incentivando a preferência dos prestadores de serviços pelos clientes com capacidade de pagamento, entre esses os beneficiários de planos empresariais. Em clara concessão às pressões da categoria médica, o agente regulador de preços deixa de ser o governo e passa a ser a $\mathrm{AMB}$, cuja tabela se torna a referência tanto para o sistema público quanto para o privado.

Além da ação governamental, o crescimento da assistência supletiva foi muito influenciado pelas ações das entidades representativas dos prestadores privados, que iriam se adaptar à nova clientela de origem privada, passando a ter uma relação mais seletiva com o setor público. No final da década de 80 , houve uma tendência de afastamento progressivo dos hospitais com maior incorporação de tecnologia dos credenciamentos com o setor público, exceto para os procedimentos mais rentáveis e não cobertos pelo sistema supletivo. As ações mais importantes da FBH se dividiam entre ampliar os atendimentos via sistemas privados de assistência e buscar extrair mais recursos do setor público em uma disputa reiterada e constante em torno da ampliação dos valores dos serviços. Por sua vez, a AMB buscou assumir o papel de regulador de preços e sempre ofereceu resistências a qualquer forma de controle administrativo ou orçamentário, além de defender a livre escolha do profissional pelo paciente. Por essas razões, mesmo sendo cada vez mais atraída pelo mercado privado, ofereceu resistências ao caráter empresarial da assistência privada, expressando o conflito de interesses entre as entidades médicas e as empresas e operadoras de planos de saúde. Tal conflito expressou-se no crescimento das cooperativas médicas. 
No final da década, intensificou-se a comercialização de planos de saúde individuais não apenas pelas cooperativas médicas, que tinham começado suas atividades nesse segmento e iriam se desenvolver muito nesse período, mas também pela medicina de grupo ${ }^{82}$ e pelas grandes seguradoras, que entram no ramo saúde, atendendo a uma demanda de segmentos da população de renda mais alta, justificada pelo alto custo da medicina privada. Contudo, mantevese a forte preponderância da clientela empresarial no caso da medicina de grupo, ${ }^{83}$ que deixa de ser restrita ao operariado dos setores industriais e amplia sua cobertura para os assalariados de grandes, médias e pequenas empresas do setor terciário e sindicatos e associações profissionais (Bahia, 1991). Ainda na década de 80 , dá-se a incorporação de funcionários públi$\cos \mathrm{da}$ administração direta e da indireta à assistência médica supletiva de caráter coletivo (Bahia \& Viana, 2002).

Decisões governamentais também incentivaram a opção individual pela assistência privada. A política tributária, ao permitir deduções da renda tributável das pessoas físicas para fins de pagamento do imposto sobre a renda, contribuiu para a inserção nos planos privados ou, mesmo, para a utilização da medicina liberal (desembolso direto) de pessoas provenientes dos estratos de renda mais altos. Apesar das limitações da utilização dos dados oficiais relativos a essas deduções, eles permitem visualizar como esse tipo de benefício tributário favorece principalmente as pessoas com maiores rendas, constituindo uma despesa governamental questionável do ponto de vista da eqüidade ou, mesmo, da igualdade, elencada como um dos princípios constitucionais do sistema público de saúde. Os dados mais recentes da Secretaria da Receita Federal (2002) mostram algumas evidências esperadas: os de maior renda

82 A entrada da medicina de grupo na comercialização de planos individuais se deu, principalmente, com a Golden Cross, com base no modelo americano das HMO. Ainda durante o governo militar, a Golden Cross foi reconhecida como entidade filantrópica, o que significou um estímulo governamental para seu desenvolvimento por meio de subsídios fiscais. Posteriormente, a empresa perdeu esse privilégio, o que foi uma das razões para seu retrocesso. Dos cerca de três milhões de cobertos que chegou a possuir, passou a cerca de apenas trezentos mil atualmente. Mas a empresa foi também pioneira no ramo de seguros-saúde, criando uma seguradora nos anos 90. A Golden Cross funcionou como um modelo para o segmento no ramo de planos para pessoas físicas (de acordo com entrevista com José Fernando Rossi, presidente da Abramge/MG, em outubro de 2002)

83 Em 1988, 96,4\% dos convênios eram com empresas e apenas 3,6\% com indivíduos (Mendes, 1993). 
gastam mais com saúde e, conseqüentemente, deduzem maiores valores. ${ }^{84}$ Se considerarmos que a renúncia tributária é parte do gasto governamental com saúde, pode-se concluir que esse gasto público indireto com saúde decorrente do benefício tributário da dedução do total das despesas com assistência médica beneficia aqueles contribuintes de maior renda, além de constituir um incentivo à não-utilização do sistema público, uma vez que, pelo menos em parte, os gastos individuais com saúde acabam sendo cobertos pelo governo indiretamente. Do ponto de vista da legitimação dos serviços públicos, a renúncia fiscal nesse caso fragiliza mais o setor público, ao favorecer a exclusão de sua cobertura dos cidadãos de maior poder aquisitivo, cujo comportamento, de forma indireta, é estimulado pela política tributária.

Nos anos 90, a assistência à saúde nas empresas passa a ser "um benefício de forte apelo para atração e manutenção de quadros pessoais qualificados" (Ciefas, 2000: 18-19). Mas o crescimento dos custos, alavancado pelas entidades médicas, será um fator limitador do crescimento da assistência supletiva. ${ }^{85}$ A crise econômica do período e as mudanças tecnológicas, com a redução dos postos de trabalho, levaram as empresas a restringir seus custos para sobreviver. Isso teve conseqüências negativas sobre a expansão dos planos próprios de empresa, que registraram diminuição significativa no número de beneficiários. As seguradoras serão o único segmento da assistência supletiva a

84 Essas deduções são indicativas do desembolso direto com saúde dos segmentos da população que são obrigados a fazer a declaração anual em razão do patamar de renda. A utilização dos dados da Receita Federal relativos a essas deduções apresenta algumas limitações, como o fato de que nos últimos anos muitos contribuintes fazem a opção pelo 'formulário simplificado', no qual todas as deduções permitidas por lei são substituídas por um desconto padrão de $20 \%$ da renda tributável até um limite, e sem especificação dos gastos dedutíveis. Além disso, os dados dos contribuintes que fazem a declaração completa não permitem a desagregação por tipo de despesas médicas, que tanto podem ser gastos com mensalidades de planos de saúde quanto aqueles relativos a pagamento direto aos prestadores de serviços de saúde. Em 2001, do total de declarantes do Imposto de Renda, um pouco mais de $60 \%$ usou o formulário simplificado, cujo rendimento foi de apenas $30 \%$ dos rendimentos totais declarados e $44 \%$ dos rendimentos tributáveis (Ministério da Fazenda - SRF/2002). Para os contribuintes que optaram pelo formulário completo, a dedução relativa a despesas médicas foi de cerca de $\mathrm{R} \$ 13,5$ bilhões - sendo o item de maior dedução relativa, $19 \%$ do total das deduções - e beneficiou cerca de 3,5 milhões de pessoas, com a média de $\mathrm{R} \$ 3.851,44$ por pessoa. A dedução média é progressiva em razão dos rendimentos e alcançou $\mathrm{R} \$ 7.834,36$ entre os declarantes da faixa de renda anual mais alta (acima de $\mathrm{R} \$ 120$ mil).

85 A partir de 1994, a medicina de grupo reconhece uma fase de lenta expansão e, até, de retração, atribuída às conseqüências da estabilização da moeda e à redução dos índices inflacionários, que impossibilitou que as operadoras contrabalançassem aumentos de custos com as receitas financeiras, dada a queda das taxas nominais de juros. 
se expandir na década, embora se constituam na modalidade empresarial mais recente no mercado e ainda com o menor número de clientes. ${ }^{86}$

Embora as Unimeds tenham sido criadas em oposição à medicina de grupo e ainda usufruam as vantagens legais decorrentes do fato de serem uma cooperativa - portanto, instituições não-lucrativas -, o seu desenvolvimento mostra cada vez mais as suas similaridades em relação às características da assistência e ao desenvolvimento empresarial. No final da década de 70, ambas as modalidades institucionais se reestruturaram do ponto de vista empresarial, ocorrendo associações entre empresas, vinculação a grupos empresariais de outros ramos e aquisição de estabelecimentos de saúde. Nos anos 80, passaram a associar-se a segmentos do setor financeiro ou a criar suas próprias seguradoras e diversificaram suas atividades, passando a conformar redes de cuidados e assistência médica, que incluem empresas de transporte aéreo e terrestre e cuidados domiciliares (Bahia, 1999). ${ }^{87}$

A par dessas transformações que atingem os grandes grupos empresariais, surgem pequenas empresas voltadas para o atendimento de demandas individualizadas de segmentos com menor poder aquisitivo e localizados em áreas mais carentes, que oferecem planos de saúde com menor preço e mais baixos níveis de cobertura, utilizando redes de prestadores mais regionalizadas e restritas do ponto de vista tecnológico. Particularmente no âmbito de hospi-

86 As seguradoras se caracterizam por ofertar os planos de maior custo, geralmente voltados para os níveis mais altos da hierarquia da empresa. Como essa parcela dos empregados parece ser a mais valorizada em razão da necessidade de quadros qualificados, que passa a ser considerada como um elemento fundamental para garantir a competitividade das empresas, é possível supor que a expansão das seguradoras esteja associada à expansão de planos de saúde de padrão mais elevado, em detrimento dos planos voltados para toda a massa de empregados de uma empresa.

87 A evolução das cooperativas médicas indica um processo similar de expansão empresarial. O conjunto das Unimeds constitui hoje o que se denomina 'Complexo Empresarial Cooperativo Unimed', que inclui, além das cooperativas de trabalho médico, cooperativas de usuários (Usimeds), cooperativas de crédito (Unicreds), a Fundação Unimed e, ainda, oito empresas, entre essas uma seguradora. Por meio da Central Nacional Unimed - uma operadora nacional de planos de saúde, criada após a regulamentação dos planos de saúde - oferece assistência médica empresarial com benefícios especiais e atendimento diferenciado com abrangência nacional, ou seja, comercializa produtos diferenciados de acordo com a opção - e recursos - do cliente/empresa. Para treinamento dos profissionais, conta com uma universidade, o Núcleo Educacional da Fundação Unimed, baseado no modelo de universidade corporativa. Um sistema de cooperativas de crédito administra e otimiza recursos gerados pelas empresas do sistema Unimed e financia a compra de equipamentos, construção de hospitais e outras unidades prestadoras de serviços. Cooperativas de usuários, entre outras vantagens de uma cooperativa de consumo, visam ao acesso a serviços não previstos contratualmente pelos planos de saúde, via convênios com diferentes empresas (Unimed Brasil, 2002). 
tais, passaram a ser comercializados planos de saúde voltados para consumidores individuais. Considerados como uma solução para a crise financeira dos hospitais, essa modalidade tem se desenvolvido com mais intensidade em cidades do interior do país, embora não se restrinjam a elas, e também em instituições filantrópicas. Nesse último caso, causam polêmica, em razão das isenções fiscais a que fazem jus, situação que entra em contradição com o caráter lucrativo dos planos de saúde. Operando no sistema de pré-pagamento, os hospitais atuam ao mesmo tempo como órgão arrecadador e prestador de serviços.

Nos últimos anos, observa-se uma interpenetração dos segmentos comercial e não-lucrativo, por meio da ampliação dos planos de autogestão administrados por empresas de medicina de grupo, cooperativas e seguradoras. Nesses casos, em que a empresa que mantém assistência para seus empregados opta por uma administração terceirizada por meio de planos de pós-pagamento, acabam se entrecruzando e aproximando cada vez mais os diferentes segmentos da assistência supletiva. ${ }^{88}$

Até recentemente, além dos incentivos legais à concessão de planos privados de saúde pelas empresas empregadoras, outros incentivos fiscais favoreciam as empresas médicas, particularmente a isenção de tributação para as entidades sem fins lucrativos, que incide sobre cooperativas médicas e as medicinas de grupo vinculadas a instituições filantrópicas. Pressões governamentais têm ocorrido no sentido de retirar as isenções que beneficiam as cooperativas médicas e as entidades chamadas de filantrópicas, muitas delas comercializando planos de saúde. A regulamentação pública dessa atividade privada no final da década trouxe a necessidade de novas adaptações em face da exigência de ampliação da cobertura oferecida, com reflexos nos custos e na

88 Nos chamados 'planos de administração', a empresa entrega a administração de seu programa de saúde a outra empresa, mediante o pagamento de uma taxa de administração, e pelo sistema de pós-pagamento cobre os gastos com os serviços efetivamente realizados. Essa alternativa é uma opção para empresas menores que não conseguem arcar com um sistema de autogestão ou quando não querem assumir esses encargos administrativos, as quais têm um custo menor do que a contratação de uma operadora comercial. De acordo com Mendes (1993), os planos de administração em 1989 cobriam quatrocentos mil beneficiários, apenas 1,3\% do total da atenção médica supletiva. Dados da pesquisa anual da Towers e Perrin de 1999/2000 mostram que a gestão terceirizada era utilizada por $23 \%$ das 237 empresas pesquisadas, o que poderia ser feito por empresas especializadas ou por qualquer forma de operadora. De acordo com o cadastro da ANS, em dezembro de 2001 as administradoras constituíam 3\% das operadoras de planos de saúde e cobriam menos de $1 \%$ dos beneficiários. 
lucratividade, e passou a exigir mudanças na configuração jurídica das instituições privadas de assistência à saúde, particularmente as seguradoras e os hospitais.

\section{Características e Dimensões das Diferentes Moda- lidades Institucionais da Assistência Privada}

\section{Planos coletivos empresariais}

Apesar de partilharem muitos aspectos comuns, há diferenças entre as diversas modalidades institucionais quanto à forma de inserção dos usuários, personalidade jurídica, localização, cobertura e preços, entre outras. As dimensões respectivas também divergem, bem como sua evolução no tempo.

Não existem dados disponíveis que informem quantas empresas mantêm assistência à saúde para seus empregados ou que permitam identificar a dimensão de cada uma das formas institucionais pelas quais empresas e outros tipos de organizações prestam assistência à saúde aos seus empregados ou associados. Algumas pesquisas feitas com empresas de consultoria ou por agentes do mercado fornecem algumas indicações.

Uma estimativa da incidência de assistência médica empresarial pode ser obtida de dados de uma pesquisa sobre qualidade na indústria realizada em 1995, em âmbito nacional e abrangendo todas as atividades econômicas, pelo BNDES, pela Confederação Nacional da Indústria e pelo Serviço Brasileiro de Apoio às Micro e Pequenas Empresas (Sebrae). Com base nas respostas das 1.356 que responderam a questionários enviados para 7.906 empresas, constatou-se que $54 \%$ das indústrias incluíam planos de saúde entre os benefícios concedidos aos trabalhadores. O número de empresas sem planos de saúde era mais freqüente entre as microempresas e as de pequeno e médio porte. Entretanto, considerando o número de empregados das empresas com planos, e com base no suposto da pesquisa de que todos os trabalhadores das empresas que possuíam planos de saúde estariam cobertos, a cobertura era de $91 \%$, sendo que $21 \%$ dos empregados de microempresas tinham plano, $53 \%$ das pequenas, $8 \%$ das médias e $96 \%$ dos localizados em grandes indústrias (Bahia, 1999). 
Pesquisas anuais realizadas pelas empresas MW Consultores e Towers Perrin em amostra de empresas são também indicativas das modalidades de opções empresariais. Considerando o período de 1988/2002, essas pesquisas em amostras não representativas de menos de trezentas empresas sugerem que os planos de pré-pagamento, contratados de operadoras comerciais, são predominantes desde os anos 80 em relação aos planos de autogestão geridos pela própria empresa (Tabela 2). ${ }^{89}$ A terceirização da administração de planos próprios de empresas, embora seja minoritária, cresceu na década de 90 , quando também houve crescimento significativo da contratação de seguradoras em detrimento da medicina de grupo e das cooperativas médicas (Tabela 3). Esse crescimento expressa, em parte, o fato de as seguradoras terem entrado no mercado também na qualidade de administradoras de planos próprios das empresas, e não apenas como operadoras de planos.

Tabela 2 - Proporção de planos coletivos por tipo em amostra de empresas. Brasil, 1988-2002

\begin{tabular}{c|c|c|c|c|c|c}
\hline Ano & \multicolumn{3}{|c|}{$\begin{array}{c}\text { Auto-segurado (pós- } \\
\text { pagamento) }\end{array}$} & $\begin{array}{c}\text { Segurado (pré- } \\
\text { pagamento) }\end{array}$ & Misto (\%) & $\begin{array}{c}\text { Número de } \\
\text { empresas } \\
\text { pesquisadas }\end{array}$ \\
\hline 1988 & 14 & 9 & 26 & 64 & $\ldots$ & 230 \\
1997 & $\ldots$ & $\ldots$ & 33 & 55 & 12 & 294 \\
$1999 / 2000$ & 14 & 23 & 37 & 49 & 14 & 257 \\
$2001 / 2002$ & 17 & 14 & 30 & 59 & 11 & 221 \\
\hline
\end{tabular}

Fontes: 1988 - MW Consultores; 1997, 1999/2000, 2001/2002 - Towers Perrin, Planos de Benefícios no Brasil.

Nota: planos segurados - aqueles em que a empresa prestadora assume o risco em troca de um prépagamento mensal por parte da empresa tomadora e se viabilizam por meio da medicina de grupo, de cooperativas médicas ou seguro-saúde. Plano auto-segurado - aquele em que a empresa tomadora assume o risco, pagando pelos serviços efetivamente utilizados, e se viabiliza por meio da administração de terceiros (Towers Perrin, 1997).

89 Quando a empresa opta pela contratação de uma operadora comercial, a administração do plano é feita conjuntamente pela empresa empregadora e pela operadora, em um modelo de co-gestão, por meio do sistema de pré-pagamento, em que as empresas pagam antecipadamente um determinado valor por empregado ou dependente segurado, correspondente à modalidade de assistência contratada. 
Tabela 3 - Proporção de planos empresariais segurados (pré-pagamento) e auto-segurados com administração terceirizada, por tipo de instituição contratada, em amostra de empresas. Brasil, 1988-2002

\begin{tabular}{l|c|c|c|c|c}
\hline \multicolumn{1}{c|}{ Ano } & $\begin{array}{c}\text { Medicina } \\
\text { de grupo } \\
(\%)\end{array}$ & $\begin{array}{c}\text { Cooperativa } \\
\text { médica (\%) }\end{array}$ & $\begin{array}{c}\text { Seguradora } \\
(\%)\end{array}$ & $\begin{array}{c}\text { Administradora de } \\
\text { planos (\%) }\end{array}$ & $\begin{array}{c}\text { Número de } \\
\text { empresas } \\
\text { pesquisadas }\end{array}$ \\
\hline 1988 & $58^{(*)}$ & $\ldots$ & 16 & $\ldots$ & 230 \\
1997 & 32 & 33 & 45 & 18 & 294 \\
$1999 / 2000$ & 31 & 35 & 50 & 22 & 257 \\
$2001 / 2002$ & 26 & 23 & 51 & 14 & 221 \\
\hline
\end{tabular}

Fontes: 1988 - MW Consultores; 1997, 1999/2000, 2001/2002: Towers Perrin, Planos de Benefícios no Brasil.

Nota: como a metodologia das pesquisas não é explicada nas publicações respectivas, supomos que os valores não somam $100 \%$ em razão da existência de várias modalidades de planos em uma mesma empresa, conforme as mesmas pesquisas identificam.

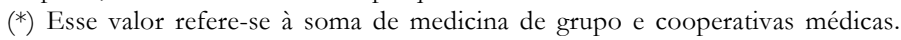

Entretanto, se essas pesquisas sugerem que os planos de autogestão estejam presentes em uma proporção menor de empresas, eles concentram o maior número de beneficiários de planos coletivos, o que é justificado pela sua concentração em empresas estatais, de maior porte. De acordo com a pesquisa de 2001 / 2002 da Towers Perrin, a autogestão concentrava 48\% das pessoas cobertas por planos empresariais; em segundo lugar, estavam as seguradoras, cobrindo $17 \%$ dos beneficiários de planos empresariais, seguidas pelas medicinas de grupo $(13 \%)$ e, por último, as cooperativas médicas, com a menor cobertura de planos coletivos ( $9 \%$ dos beneficiários).

Pesquisa realizada em 1997 pelo Ciefas (1997, apud Bahia, 1999), também em amostra de empresas, revelou maior número de sistemas de autogestão, em ordem decrescente, nas companhias de telecomunicação, em bancos principalmente estatais - e empresas públicas de energia e petróleo. ${ }^{90}$

Estimativas mais gerais produzidas pelas entidades representativas dos planos de autogestão mostram um crescimento de cobertura de $130 \%$ no

90 $\quad$ Estimativas apresentadas por Luiz Carlos Andrea, presidente do Ciefas, em audiência pública na Câmara dos Deputados, realizada em 19/11/1996, por ocasião da tramitação do projeto de lei regulamentando os planos e seguros de saúde, indicavam que os planos vinculados a instituições públicas correspondiam a cerca de $62 \%$ do total de autogestão. 
período de 1987 /2000, passando de 5,1 milhões para 11,7 milhões de pessoas cobertas, em trezentas organizações privadas e públicas, como pode ser visto na Tabela $4 .{ }^{91}$

\section{As modalidades de operadoras}

De acordo com as estimativas elaboradas pela Abramge, ${ }^{92}$ no início da década de 70 o número de empresas de medicina de grupo alcançava no máximo uma centena, porém durante a década de 80 esse número cresce cerca de $200 \%$, passando para trezentas empresas em 1987, e continua a crescer na década de $90,{ }^{93}$ embora nessa época isso não tenha sido acompanhado de crescimento correspondente ao número de clientes, sejam empresas, sejam indivíduos (Tabela 4). O número de empresas que contratavam a medicina de grupo para prover a assistência a seus empregados passou de menos de três mil na primeira metade da década de 70 para cerca de dez mil na segunda metade da década seguinte, período em que se abriu o caminho para o desenvolvimento da medicina de grupo, independentemente dos subsídios da Previdência Social. Em um período de apenas dez anos (1977/87) o número de beneficiários teve uma ampliação superior a 100\%, passando de seis milhões para 13 milhões, aproximadamente. No período de 1987 a 1994, o número de empresas clientes cresceu ainda mais de quatro vezes, embora o de pessoas cobertas tenha tido um crescimento relativamente bem mais tímido (cerca de $23 \%$ ). A partir de meados da década de 90 , o crescimento tanto de empresas contratantes quanto de beneficiários torna-se irrisório, embora ainda seja a modalidade de assistência privada que apresenta a maior cobertura no conjunto do país: 38,5\% do total de beneficiários de planos de saúde, de acordo com dados da ANS de dezembro de 2006.

$\overline{91}$ Esses números são bastante superiores aos registrados pela Agência Nacional de Saúde Suplementar, os quais são: 3.934.010 beneficiários em dezembro de 2001 e 5.399 .644 em dezembro de 2006 .

92 Os dados das entidades representativas das operadoras apresentam inconsistências e discrepâncias acentuadas, conforme o momento de sua produção. $\mathrm{Na}$ inexistência de outros, a alternativa é usá-los apenas de forma indicativa. Como os depoimentos de seus representantes, colhidos em entrevistas pessoais, ou as de publicações, confirmam as tendências registradas, eles são úteis nesse sentido.

93 Em dezembro de 2006, a ANS registra a existência de apenas 686 empresas de medicina de grupo em operação. 
Tabela 4 - Estimativas da evolução da clientela da assistência privada segundo a modalidade. Brasil, 1976-2000

\begin{tabular}{|c|c|c|c|c|c|c|c|c|}
\hline \multirow{2}{*}{ Ano } & \multicolumn{2}{|c|}{$\begin{array}{c}\text { Planos próprios de } \\
\text { empresas }\end{array}$} & \multicolumn{2}{|c|}{ Medicina de grupo } & \multicolumn{2}{|c|}{ Cooperativas médicas } & \multicolumn{2}{|c|}{ Seguradoras } \\
\hline & Clientes & $\begin{array}{c}\text { Aumento } \\
\%\end{array}$ & Clientes & $\begin{array}{c}\text { Aumento } \\
\%\end{array}$ & Clientes & $\begin{array}{l}\text { Aumento } \\
\%\end{array}$ & Clientes & $\begin{array}{c}\text { Aumento } \\
\%\end{array}$ \\
\hline 1976 & $\ldots$ & $\ldots$ & 5.537 .799 & Ano-base & $\ldots$ & $\ldots$ & $\ldots$ & $\ldots$ \\
\hline \multirow{2}{*}{1977} & $\ldots$ & $\ldots$ & 5.978 .371 & 7,96 & $\ldots$ & $\ldots$ & $\ldots$ & $\ldots$ \\
\hline & & & 7.000 .000 & & & & & \\
\hline 1981 & $\ldots$ & $\ldots$ & 8.500 .000 & 42,18 & $\ldots$ & $\ldots$ & $\ldots$ & $\ldots$ \\
\hline 1982 & $\ldots$ & $\ldots$ & $\ldots$ & $\ldots$ & $\ldots$ & $\ldots$ & 697.193 & Ano-base \\
\hline \multirow{2}{*}{1987} & 4.800 .000 & \multirow{2}{*}{ Ano-base } & 13.000 .000 & 52,94 & 3.439 .855 & \multirow{2}{*}{ Ano-base } & 800.000 & 14,75 \\
\hline & 5.100 .000 & & $(15.000 .000)$ & & $(3.500 .000)$ & & & \\
\hline \multirow[t]{2}{*}{1989} & $\begin{array}{c}7.500 .000 \\
(7.900 .000)\end{array}$ & 56,25 & 15.000 .000 & 15,38 & 7.300 .000 & 112,22 & 940.000 & 17,50 \\
\hline & 7.900 .000 & & & & & & & \\
\hline 1990 & $\ldots$ & $\ldots$ & $\ldots$ & $\ldots$ & 8.500 .000 & 16,44 & $\ldots$ & $\ldots$ \\
\hline 1991 & 5.770 .000 & $-26,96$ & 13.500 .000 & $-10,00$ & 8.000 .000 & $-5,88$ & $\ldots$ & $\ldots$ \\
\hline \multirow{2}{*}{1992} & 6.500 .000 & 12,65 & 15.000 .000 & 11,11 & 7.000 .000 & $-12,50$ & $\ldots$ & $\ldots$ \\
\hline & & & & & $(8.000 .000)$ & & & \\
\hline 1993 & 6.900 .000 & 6,15 & 16.000 .000 & 6,67 & 8.500 .000 & 21,43 & $\ldots$ & $\ldots$ \\
\hline 1994 & $\ldots$ & $\ldots$ & 16.000 .000 & 0,00 & $\ldots$ & $\ldots$ & 5.000 .000 & 431,91 \\
\hline \multirow{2}{*}{1995} & 8.000 .000 & 15,94 & 16.800 .000 & 5,00 & 6.254 .172 & $-26,42$ & 5.000 .000 & 0,00 \\
\hline & $(10.000 .000)$ & & & & $(9.000 .000)$ & & & \\
\hline 1996 & $\ldots$ & $\ldots$ & 17.300 .000 & 2,98 & $\ldots$ & $\ldots$ & $\ldots$ & $\ldots$ \\
\hline 1997 & 8.000 .000 & 0,00 & 17.800 .000 & 2,89 & $\ldots$ & $\ldots$ & 5.000 .000 & 0,00 \\
\hline 1998 & $\ldots$ & $\ldots$ & 18.300 .000 & 2,81 & 10.671 .000 & 70,62 & 5.000 .000 & 0,00 \\
\hline 1999 & $\ldots$ & $\ldots$ & 18.000 .000 & $-1,64$ & 11.000 .000 & 3,08 & 6.000 .000 & 20,00 \\
\hline 2000 & 11.700 .000 & 46,25 & 18.400 .000 & 2,22 & $\ldots$ & $\ldots$ & $\ldots$ & $\ldots$ \\
\hline
\end{tabular}

Fontes: Bahia (1999), Mendes (1993), Abramge (2002), Médici (1990), Ciefas (2000).

Notas: de acordo com a fonte, há inconsistências nos dados. Nestes casos, um segundo valor foi colocado entre parênteses; o crescimento percentual foi calculado sobre o valor menor. Sinal (...): dado não disponível.

Essas estimativas confirmam a afirmação de que a expansão da medicina de grupo foi alicerçada na assistência prestada pelas empresas aos seus empregados. O crescimento da clientela se deu a partir dos contratos com empresas empregadoras, situação que permanece ainda hoje, sendo que no período de 1998/2001 os beneficiários de planos empresariais representavam entre 75\% e $80 \%$ do total das pessoas assistidas pelas empresas de medicina de grupo (Abramge, 2002). Correlatamente, no máximo 25\% eram beneficiários de 
planos assistenciais individualmente contratados, sem a intermediação de empresas empregadoras.

A expansão do número de empresas de medicina de grupo, inclusive em regiões de menor concentração de usuários, mostra o crescimento desse segmento empresarial, indicando a grande competitividade prevalecente e a tendência para a proliferação de empresas de menor porte, isto é, com pequeno número de beneficiários e coberturas mais restritas quanto aos serviços oferecidos, conforme ilustra o Gráfico 1. Apesar disso, o setor ainda é bastante concentrado, na medida em que pouco mais de $2 \%$ das empresas concentram cerca de 35\% dos beneficiários. As maiores empresas se localizam em São Paulo e Rio de Janeiro, e as menores proliferam em outras regiões, principalmente na Norte, e em cidades do interior, no movimento recente ligado à criação de grupos médicos em hospitais.

Gráfico 1 - Proporção de empresas de grupo por porte e número de beneficiários. Brasil, 2002

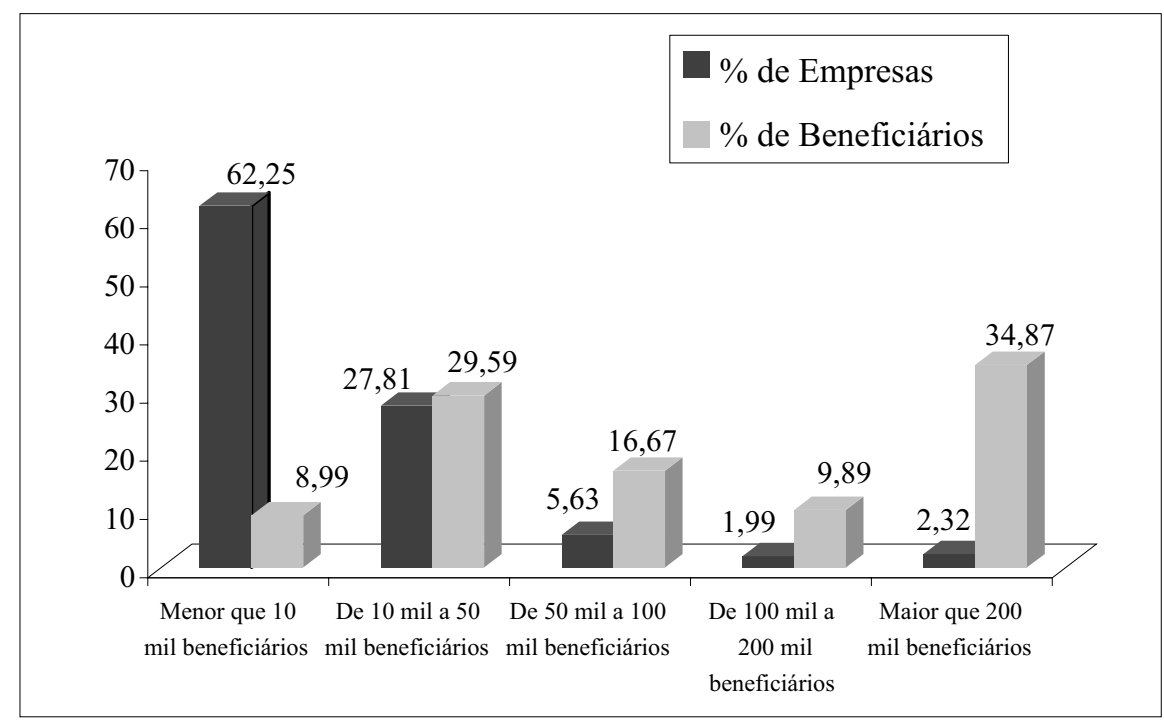

Fonte: Abramge (2002).

Nota: as categorias foram transcritas da fonte. 
É possível inferir que o crescimento de empresas que contratam a medicina de grupo, sem a ampliação dos usuários na mesma proporção, confirma a expansão dos planos empresariais para além do âmbito das grandes empresas, que marcara o seu surgimento, e indica redução ou, no mínimo, pequena ampliação dos postos de trabalho nas empresas em geral, característica da década de 90.

A distribuição da clientela da medicina de grupo é geograficamente bastante desigual e reflete a distribuição das empresas por porte e a expansão nas regiões mais desenvolvidas do ponto de vista econômico, além de, como informa a Abramge, ela estar presente apenas nas cidades com mais de quarenta mil habitantes. Em 2000, na região Sudeste concentram-se aproximadamente $80 \%$ dos beneficiários e $65 \%$ das empresas de medicina de grupo, sendo mais da metade dos beneficiários e um terço das empresas apenas em São Paulo (Tabela 5). Na região Norte, a inserção da medicina de grupo é bem pequena, congregando pouco mais de $1 \%$ dos beneficiários, embora com mais de 3\% das empresas, mostrando a expansão recente de empresas de menor porte em busca de novos mercados. ${ }^{94}$ Pouco mais de $6 \%$ da população do país é coberta por planos de saúde comercializados pela medicina de grupo, sejam individualmente contratados, sejam coletivos, atingindo em São Paulo 16,5\% da população (Anuário Estatístico de Saúde, 2001).

94 De acordo com o cadastro da ANS/MS, em dezembro de 2006, das empresas de medicina de grupo em operação, 63,7\% estavam localizadas na região Sudeste e apenas $2,1 \%$ na região Norte. 
Tabela 5 - Distribuição das empresas e dos beneficiários da medicina de grupo segundo a Unidade Federativa (\%). Brasil, 2001

\begin{tabular}{l|c|c|l|c|c}
\hline \multicolumn{1}{c|}{$\begin{array}{c}\text { Unidade } \\
\text { Federativa }\end{array}$} & Empresas & Beneficiários & $\begin{array}{c}\text { Unidade } \\
\text { Federativa }\end{array}$ & Empresas & Beneficiários \\
\hline Acre & 0,14 & 0,1 & Bahia & 0,97 & 3,09 \\
Amazonas & 0,42 & 0,52 & NORDESTE & 8,61 & 7,6 \\
Roraima & 0,14 & 0,02 & Minas Gerais & 10,97 & 2,32 \\
Rondônia & 0,42 & 0,24 & São Paulo & 42,08 & 57,86 \\
Pará & 2,08 & 0,51 & Rio de Janeiro & 8,75 & 17,03 \\
Amapá & 0,14 & 0,03 & Espírito Santo & 2,78 & 0,86 \\
Tocantins & 0,14 & 0,06 & SUDESTE & 64,58 & 78,07 \\
NORTE & 3,48 & 1,48 & Paraná & 6,94 & 2,42 \\
Maranhão & 0,83 & 0,37 & Santa Catarina & 1,11 & 0,17 \\
Piauí & 0,56 & 0,38 & Rio Grande do Sul & 8,47 & 9,04 \\
Ceará & 1,25 & 0,55 & SUL & 16,52 & 11,63 \\
Rio Grande do & 0,97 & 0,32 & Distrito Federal & 1,67 & 0,49 \\
Norte & 0,69 & 0,24 & Mato Grosso & 0,97 & 0,17 \\
Paraíba & 2,36 & 1,87 & Mato Grosso do & 0,97 & 0,05 \\
Pernambuco & 0,56 & 0,59 & Goil & 3,19 & 0,52 \\
Alagoas & 0,42 & 0,19 & CENTRO-OESTE & 6,8 & 1,23 \\
Sergipe & 100 & 100 & TOTAL & 100 & 100 \\
\hline TOTAL & & & \\
\hline
\end{tabular}

Fonte: Abramge (2002).

Tendo surgido posteriormente, a expansão das cooperativas médicas ocorreu após a da medicina de grupo, sendo maior no final da década de 80 , a maioria sediada em cidades do interior de São Paulo: em 1969 existiam apenas trinta cooperativas; em 1977, esse número passou para sessenta, espalhadas por todo o país, embora a maioria no interior de São Paulo, possuindo apenas sete convênios com empresas; em 1987 o número de cooperativas já atingia 150, possuindo aproximadamente 3,5 milhões de clientes; em 1992 eram 221, e já então tinham como clientes 29.972 empresas e sete milhões de beneficiários; em 1999 já eram 367 cooperativas, com setenta mil clientes empresas e 11 milhões de pessoas cobertas (Unimed Brasil e Abramge apudBahia, 
1999). ${ }^{95}$ Nos anos 90 , a expansão das cooperativas foi relativamente bem maior do que a da medicina de grupo: ao passo que em 1987 seus beneficiários correspondiam a cerca de $25 \%$ dos da medicina de grupo, essa proporção atinge 61\% em 1999, quando a estimativa de cobertura era de 11 milhões de pessoas (Tabela 4). ${ }^{96}$

De acordo com o Anuário Estatístico de Saúde (2001), apesar de maior proporção de clientes de cooperativas médicas também se localizar na região Sudeste (63\%, sendo 34,87\% apenas em São Paulo - Tabela 6), ela é bem menor do que no caso da medicina de grupo. Em geral, verifica-se maior dispersão territorial das cooperativas e dos seus beneficiários, embora isso não descaracterize a concentração acentuada nas regiões mais desenvolvidas, onde tendem a se concentrar tanto as empresas empregadoras de médio e grande porte, que constituem planos coletivos, quanto o maior nível de renda, que possibilita a contratação de planos de saúde individuais. Entretanto, as cooperativas apresentam uma tendência progressiva para se espalharem por todo o país. A partir de 1987, observam-se grande crescimento do número de cooperativas em Minas Gerais e o surgimento de novas em vários estados da região Nordeste na década de $90 .{ }^{97}$ A tendência de ampliação de pequenas cooperativas é similar à expansão de pequenas empresas de medicina de grupo mais dispersas territorialmente, mostrando a expansão de novos mercados para a assistência médica supletiva nos anos 90, ainda insuficiente para alterar o quadro de concentração nas regiões mais desenvolvidas. Como as cooperativas se organizam em nível municipal, estão presentes hoje em cerca de 75\% dos municípios do país (Unimed Brasil, 2002).

$\overline{95}$ Como a autora chama atenção, há variações nesses números de acordo com diferentes documentos da própria Unimed, devendo, portanto, ser considerados como aproximações.

96 Insisto que os dados são estimativas. Além disso, a Unimed não costuma fornecer os dados relativos aos seus beneficiários distinguindo os que o são individualmente ou via empresas empregadoras ou entidades de classe, o que não permite mensurar a forma principal de seu crescimento - se via planos coletivos ou individuais.

97 Em 1987 São Paulo concentrava cerca de 31\% das cooperativas, proporção que se reduz para 23\% em 1992 e para 20\% em 1998. Por sua vez, as cooperativas de Minas Gerais passam de 12,50\% em 1987 para 19,17\% do total em 1998, situando-se apenas depois de São Paulo. O número de cooperativas da região Nordeste, que em 1987 era de apenas 25, passa para 67 em 1998, com um crescimento de $168 \%$ e com a criação de cooperativas em vários novos estados, proporção que é superior ao crescimento total verificado para o país, que foi de $156 \%$. Isso se reflete no declínio relativo do número de cooperativas na região Sul, onde em 1987 se localizavam 57\% do total e, em 1998, essa proporção foi reduzida para apenas 41\% (Bahia, 1999). 


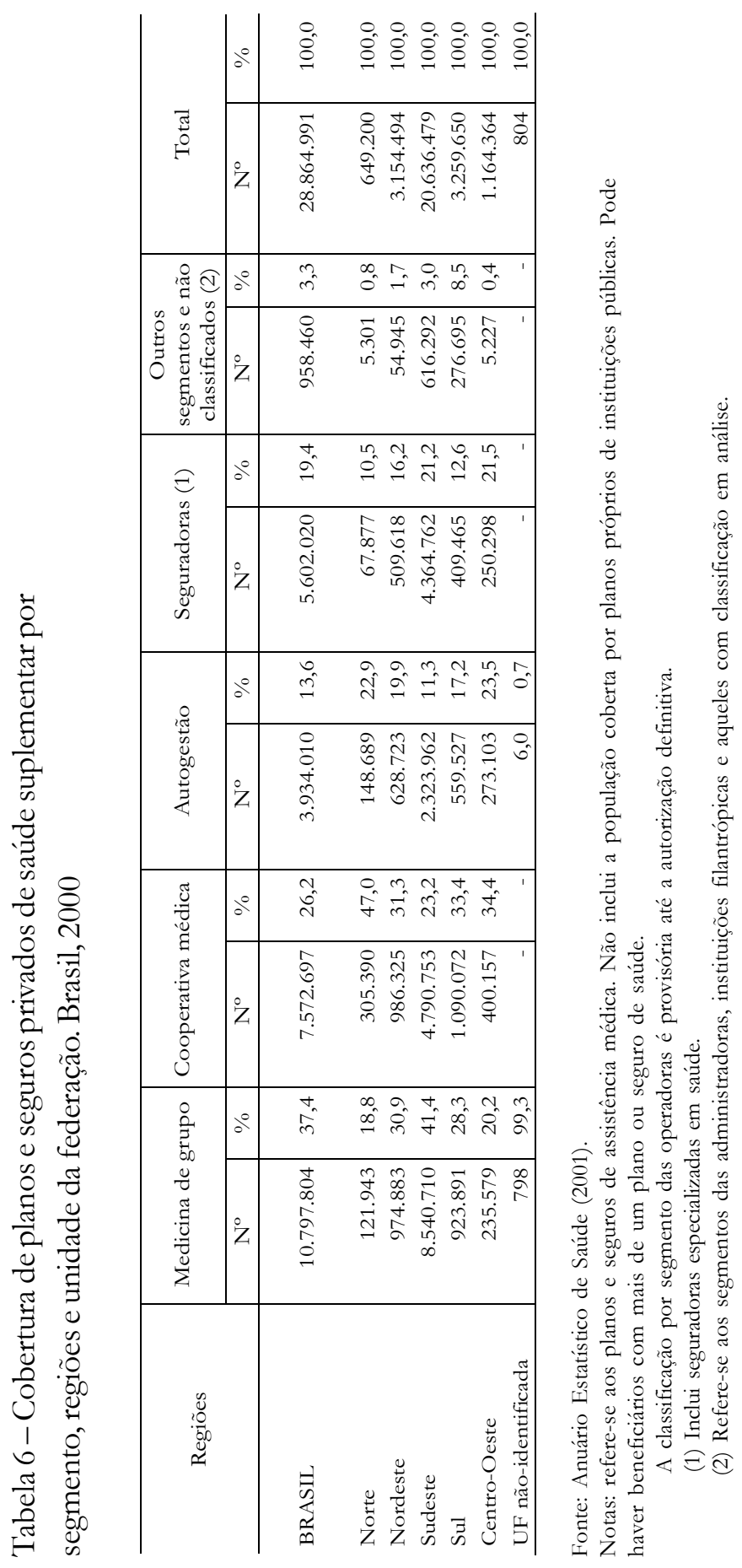


A terceira modalidade de comercialização da assistência supletiva é a dos seguros de saúde e seguros de assistência médica e/ou hospitalar. A comercialização de seguros-saúde atingiu em 1995 cerca de 15,3\% do total de prêmios de seguro, superado em 1997 apenas pelo de seguros de automóvel. Em 2001, o ramo saúde já constituía cerca de $27 \%$ do total da receita líquida de todos os prêmios, embora tenha ocorrido no período de 2000/2001 uma redução no volume de contratos de seguros, passando de $8,2 \%$ para $7 \%$ do total (Fenaseg, 2002). Em 1998, do total de 137 seguradoras atuando no Brasil, quarenta atuavam no ramo saúde. No período de dez anos (1987/97), o número de clientes das seguradoras no ramo saúde aumentou mais de seis vezes, ao passo que no mesmo período os clientes do conjunto de empresas de saúde não chegou nem a duplicar (Bahia, 1999; Tabela 4). Esses clientes se encontravam bastante concentrados, sendo que apenas duas seguradoras eram responsáveis por mais de 60\% do volume de prêmios no ramo. Em 1998, o faturamento das seguradoras já foi similar ao das outras empresas de saúde, tendo atingido US $\$ 3,5$ bilhões, embora o crescimento relativo tenha sido bastante superior (Tabela 7).

Tabela 7 - Faturamento das empresas do mercado de assistência médicasupletiva. Brasil, 1987/1989/1995-1998 (em bilhões de dólares)

\begin{tabular}{c|c|c|c|c|c|c|c|c|c|c}
\hline \multirow{2}{*}{ Ano } & \multicolumn{2}{|c|}{ Autogestão } & \multicolumn{2}{c|}{ Medicina de grupo } & \multicolumn{2}{c|}{$\begin{array}{c}\text { Cooperativas } \\
\text { médicas }\end{array}$} & \multicolumn{2}{c|}{ Seguradoras } & Total - \\
\cline { 2 - 9 } & $\begin{array}{c}\text { Bilhões } \\
\text { de } \\
\text { dólares }\end{array}$ & $\begin{array}{c}\text { Aumento } \\
\%\end{array}$ & $\begin{array}{c}\text { Bilhões } \\
\text { de } \\
\text { dólares }\end{array}$ & $\begin{array}{c}\text { Aumento } \\
\%\end{array}$ & $\begin{array}{c}\text { Bilhões } \\
\text { de } \\
\text { dólares }\end{array}$ & $\begin{array}{c}\text { Aumento } \\
\%\end{array}$ & $\begin{array}{c}\text { Bilhões } \\
\text { de } \\
\text { dólares }\end{array}$ & $\begin{array}{c}\text { Aumento } \\
\%\end{array}$ & $\begin{array}{c}\text { Aumento } \\
\% \\
\text { dólares }\end{array}$ & \\
\hline 1987 & 0,400 & Ano-base & 1,000 & Ano-base & 0,350 & Ano-base & 0,075 & Ano-base & 1,825 & Ano-base \\
1989 & 0,670 & 67,50 & 1,000 & 0,00 & 0,570 & 62,86 & 0,150 & 100,00 & 2,390 & 30,96 \\
1995 & 3,464 & 417,00 & 3,711 & 271,13 & 1,979 & 247,26 & 1,485 & 889,69 & 10,639 & 345,15 \\
1996 & 4,456 & 28,65 & 3,592 & $-3,21$ & 3,398 & 71,67 & 2,913 & 96,20 & 14,359 & 34,97 \\
$1997 / 98$ & 3,957 & $-11,21$ & 3,397 & $-5,45$ & 3,017 & $-11,21$ & 3,448 & 18,39 & 13,819 & $-3,76$ \\
\hline
\end{tabular}

Fontes: 1987 - Médici (1990); 1989 - Mendes (1993); 1990 - Asaspe-MG; 1995 a 1998 - Bahia (1999).

Nota: os valores de 1995 a 1998 foram dolarizados de acordo com as seguintes taxas cambiais:

1995 - cotação do dia 31/12/1995 (dólar 0,9716)

1996 - cotação do dia 31/12/1996 (dólar 1,0386)

1997/1998 - média da cotação do dia 31/12/1997 (1,1156) e 31/12/1998 (1,2079)

Os demais valores foram transcritos das fontes já em US\$. 
No início desta década existiam 41 seguradoras atuando no ramo saúde, a grande maioria (36) na região Sudeste, concentradas em São Paulo e Rio de Janeiro. Apesar de sua atuação ser bem mais recente, sua cobertura atingia $19,4 \%$ do total da assistência privada, um pouco mais da metade da cobertura da medicina de grupo, a pioneira no mercado privado de planos de saúde (Anuário Estatístico de Saúde, 2001; Tabela 6). ${ }^{98}$ Sua expansão mais recente tem ocorrido a partir da competição pelo mercado de planos coletivos, após constatação da limitação do mercado brasileiro de planos individuais, em razão do baixo poder aquisitivo da maioria da população e dos altos preços praticados pelas seguradoras. Na captação da clientela empresarial, muitas vezes as seguradoras utilizam a situação favorável de estarem ligadas a bancos, vinculando a concessão de empréstimos à aquisição de seguro-saúde.

\section{Diferenças e semelhanças na assistência prestada, custos e faturamento}

As coberturas dos planos de saúde na modalidade de autogestão são, em geral, bastante amplas e sem limitações de patologias ou em razão de idade; tendem a ser iguais para todos os níveis hierárquicos da empresa, embora ocorram diferenciações em alguns casos; e cobrem maior número de membros da família do empregado. ${ }^{99}$ Diferentemente, no caso das empresas que mantêm assistência médica para seus empregados mediante a contratação de

98 Essa proporção foi calculada com base nos dados do cadastro da ANS publicados no Anuário Estatístico de Saúde do Brasil 2001, que apresenta diferenças grandes em relação às informações fornecidas pelas entidades representativas da medicina de grupo e das cooperativas. De acordo com suas estimativas, a cobertura informada pela ANS corresponde apenas a aproximadamente $59 \%$ e $66 \%$, respectivamente, da cobertura atual da medicina de grupo e das cooperativas médicas. Isso se explica pelo fato de o cadastro da ANS naquela data ainda não estar completo, considerando sua atuação relativamente recente. Dados de dezembro de 2006 da ANS/MS apontam que as seguradoras especializadas cobrem apenas cerca de $11 \%$ do total de beneficiários de planos de saúde. A mesma fonte indica apenas 12 seguradoras especializadas em saúde em atividade em dezembro de 2006.

99 As pesquisas do Ciefas são a única fonte de dados disponível relativas exclusivamente a planos de autogestão. De acordo com a última pesquisa divulgada (2000) em sistemas de autogestão, 21,1\% das empresas pesquisadas admitiam como beneficiários parentes de até segundo grau e 26,3\% até de terceiro grau; apenas 52,6\% admitiam somente do primeiro grau de parentesco. Mais da metade das empresas (55\%) ofereciam acomodação para internação hospitalar tanto do tipo enfermaria quanto apartamento; $40 \%$ garantiam apenas acomodações de padrão superior (apartamento); e uma minoria, apenas enfermaria $(5 \%)$. Além disso, a maioria oferecia benefícios não previstos na legislação, como assistência farmacêutica, aparelhos ortopédicos, ótica, psicoterapia e vários tipos de transplantes. 
operadoras comerciais, costuma ocorrer segmentação de cobertura por nível hierárquico, ou seja, cobertura maior, melhores acomodações, maior disponibilidade de prestadores e valores de remuneração mais altos, em razão da posição ocupada na hierarquia da empresa. As pesquisas anuais da Towers e Perrin em amostra de empresas, apesar de não permitirem discriminar a segmentação por modalidade institucional do plano coletivo, são sugestivas: embora cerca de $45 \%$ das pessoas fossem cobertas por planos do tipo 'básico’ e 14\% pelo padrão ‘executivo’ (Pesquisa 2001 / 2002), a proporção de cada plano variava diretamente em relação com o nível hierárquico do empregado. ${ }^{100}$ A legislação regulamentadora no final dos anos 90 coibiu as limitações quanto à cobertura, levando a certa uniformização com relação aos procedimentos básicos a serem cobertos pelos planos de saúde em suas diferentes modalidades. Entretanto, permanecem diferenciações quanto aos padrões de conforto, opções de prestadores e cobertura de procedimentos não-obrigatórios de acordo com a legislação.

O financiamento dos planos de autogestão, na maioria dos casos, é feito pela organização mantenedora e pelos beneficiários em regime de co-participação. Algumas empresas financiam totalmente a assistência, ao passo que em outros planos ela é custeada totalmente pelo usuário. ${ }^{101}$ Em geral, a contribuição é proporcional à remuneração do trabalhador, o que lhes confere um caráter redistributivo, na medida em que se baseia em uma lógica solidarista. Ao contrário, os produtos comercializados pelas operadoras do mercado são planos de pré-pagamento, em que o cliente - empresa, indivíduo ou associação profissional - paga um valor mensal per capita, que varia de acordo com a modalidade da assistência oferecida. As coberturas são, em geral, mais restritas do que as dos planos de autogestão. As da medicina de grupo são inferiores às providas pelas seguradoras nos aspectos de acesso a provedores, cobertura de

\footnotetext{
${ }_{100}$ Na pesquisa para 1999/2000, no nível de diretoria, 86\% eram cobertos por plano executivo; no nível de gerência, esse percentual baixava para 58\%; para administrativos e operacionais, para 7\% e 3\%, respectivamente. Na sua grande maioria, os empregados operacionais e administrativos eram cobertos por planos do tipo básico ( $73 \%$ e $80 \%$, respectivamente).

101 De acordo com a pesquisa de 2000 do Ciefas, 80,7\% dos planos de autogestão tinham os custos financiados pelo sistema de co-participação; 14,5\% eram custeados totalmente pelo beneficiário e em apenas $4,8 \%$ as patrocinadoras pagavam integralmente os custos. Em 34,5\% dos casos, a contribuição dos beneficiários era pelo regime de pós-pagamento; em 18,2\%, pelo regime de prépagamento; e em 47,3\%, por ambos.
} 
procedimentos e menor amplitude de dependentes, o que tem como contrapartida menor preço. A livre escolha do prestador de serviços costuma ser a modalidade mais valorizada e também mais cara, e é marca do segurosaúde, bastante descaracterizada após a permissão para o referenciamento de prestadores. Essa possibilidade não é oferecida nem pela medicina de grupo nem pelas cooperativas. Nos planos coletivos em que os clientes são empresas os contratos são mais amplos, atendem a quase todos tipos de patologia (isso acontecia mesmo antes da regulamentação) e não existe prazo de carência nem diferenciação por faixa etária. Ao contrário, nos contratos individuais, em que as coberturas são variáveis, existem carências, restrições e preços diferenciados por faixa etária. Para diminuir custos, a medicina de grupo investe em medicina preventiva, aliando a lógica social à lógica econômica. ${ }^{102}$

A diferenciação nas características dos planos se reflete no custo, que apresenta grandes variações entre os planos coletivos. O custo mais alto costuma ser o das seguradoras e o mais baixo o dos planos de autogestão, o que se justifica por não terem finalidade lucrativa. Os planos de operadoras comerciais voltados para as clientelas individuais são mais caros do que os coletivos. ${ }^{103}$ Em cada modalidade de operadora, os custos variam também em razão das características do plano, sendo que um plano executivo pode ser até cinco

$\overline{102}$ Essa afirmação foi feita pelo presidente da Abramge, em Audiência Pública na Câmara do Deputados, em 9/10/1996.

103 Os dados disponíveis pelas pesquisas em amostras de empresas da Towers e Perrin apresentam variações no ranking das operadoras, mas tendem a confirmar o maior custo das seguradoras e o menor da autogestão no âmbito dos planos coletivos, que são os de menor custo. Na última pesquisa (2001/2002), o custo bruto dos planos empresariais variava de $\mathrm{R} \$ 52,06$ a $\mathrm{R} \$ 120,51$, e o custo líquido, de $\mathrm{R} \$ 41,19$ a $\mathrm{R} \$ 105,67$. A pesquisa Ciefas 2000 indicou como valor mais comum para os planos de autogestão o custo per capita entre $\mathrm{R} \$ 75,00$ e $\mathrm{R} \$ 90,00$. Pesquisa realizada por Bahia em algumas empresas de medicina de grupo em 1998 mostrou que os preços dos planos comercializados oscilavam de $R \$ 29,70$ a $R \$ 472,58$, variando em razão da faixa etária e da característica do plano (básico ou especial), mas apresentando variações de valor intra-operadoras (medicina de grupo, cooperativa médica ou seguradora) de até $220 \%$ na mesma categoria e faixa etária. De acordo com a Abramge, em 2000 o custo médio dos planos empresariais contratados com a medicina de grupo foi de $\mathrm{R} \$ 25,59$ per capita/mês, existindo planos mais caros, dependendo do tipo de atendimento contratado com a medicina de grupo. Mas, de qualquer forma, bem mais baixo do que o custo dos planos individuais, incluídos em pesquisa realizada por Bahia (1999). 
vezes mais caro do que um plano de padrão básico. ${ }^{104}$ As pesquisas da Towers e Perrin sugerem também que a participação das empresas no custo dos planos de saúde de seus empregados, considerando o conjunto de modalidades (autogestão ou contratados de operadoras comerciais) varia de acordo com o padrão do plano. Embora a participação da empresa empregadora nas empresas pesquisadas seja maior para os planos de padrão básico, ela é, em média, bem alta para os de padrão executivo - o mais caro de todos -, e para os padrões intermediários a participação da empresa no custo é bem menor. ${ }^{105}$ O custo dos planos coletivos em relação à folha de pagamento mostra-se bastante variado na amostra de empresas. Embora na maioria o custo com assistência à saúde corresponda no máximo a 7\% da folha, é possível atingir mais do que 10\% (Towers Perrin, 2001/2002). Esses dados sugerem que as empresas subsidiam mais os planos voltados para os empregados situados nos dois extremos da hierarquia ocupacional. Considerando que os planos de padrão executivo são bem mais caros, é possível inferir que estes onerem bastante os custos da empresa com esse benefício, embora sejam destinados a um número reduzido de empregados. Como a legislação permite que todos os gastos com assistência médica, sem distinção do padrão ou sem limite do valor, sejam computados como despesa operacional e, portanto, deduzidos da renda tributável para efeitos de pagamento do imposto sobre a renda de pessoas jurídicas, o subsídio a plano de saúde para as pessoas com maiores níveis salariais aponta para o caráter iníquo desse benefício tributário. Para esse grupo restrito de empregados é que as empresas encontrariam, hoje, maiores

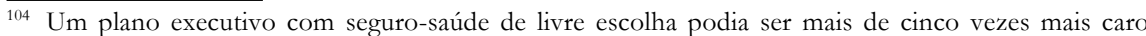
do que um plano básico da mesma operadora, segundo pesquisa da Towers Perrin de 1997. Mesmo no âmbito da autogestão, os planos executivos com livre escolha podiam ter custos mais de três vezes superiores do que o plano de padrão básico, embora essa modalidade tenda a ter menor diferenciação de preços e tipos de planos. Na pesquisa de 1999/2000, também a autogestão apresentou a menor variação de custo entre os diversos padrões de plano, e a variação maior se deu nos planos segurados com empresas de medicina de grupo. Entre as operadoras comerciais, as cooperativas médicas apresentaram menores diferenciações entre os preços de acordo com o padrão do plano, mas na de 1999/2000 essa variação era equivalente à encontrada nas seguradoras. Como a amostra de empresas pesquisadas não é necessariamente representativa, não é possível considerar esses dados como expressão da realidade. São apenas sugestivos da variação de preço de acordo com o padrão do plano e do custo menor da autogestão. A última pesquisa não apresentou dados relativos à diferenciação do custo mensal de acordo com o padrão do plano.

105 Entre as 222 empresas pesquisadas pela Towers Perrin em 2001/2002, a participação média da empresa no financiamento dos planos de padrão básico era de $86 \%$. Nos planos intermediário e superior era de apenas $78 \%$, contra $80 \%$ no plano executivo. 
incentivos para gastos em saúde com o objetivo de atrair e ou fixar um contingente de empregados de maior importância do ponto de vista estrito da ampliação da competitividade em um mundo globalizado. O gasto governamental sob a forma de renúncia tributária funcionaria, nesse caso, como mais um fator para agravar a iniqüidade da prestação da assistência médica no país.

As diferentes formas de organização dos serviços de saúde, contemplando os planos coletivos ou individuais, pelo sistema de autogestão ou mediante a contratação de operadoras comerciais de diferentes modalidades, compartilham praticamente os mesmos prestadores de serviços para a concretização da assistência. A contratação de médicos e instituições de saúde revela-se como a forma predominante para o fornecimento dos serviços, podendo conviver, em alguns casos, com a prestação de serviços diretamente pelas empresas que gerenciam serviços próprios de saúde ou pela medicina de grupo, embora em escala reduzida. A ampliação da demanda, principalmente a partir dos anos 80, promoveu a organização de redes credenciadas como provedoras das empresas empregadoras e das operadoras comerciais da assistência supletiva.

A assistência à saúde no modelo de autogestão pode ser prestada por meio do credenciamento de provedores de serviços, por serviços próprios, pelo sistema de livre escolha ou pela combinação dessas alternativas. A forma mais utilizada é o credenciamento de profissionais e instituições de saúde, remunerados de acordo com tabelas de preços previamente acordadas. Embora de forma minoritária, as empresas podem contar com serviços próprios, em geral de nível ambulatorial. No caso de livre escolha, é feito o reembolso de gastos após a utilização de profissionais e serviços disponíveis no mercado, no limite das tabelas. Pesquisa do Ciefas (2000) mostrou que o credenciamento era a forma utilizada por quase todos os planos, exceto para cerca de 1\%, em que se utilizavam apenas os serviços próprios. A combinação de credenciamento com livre escolha era a opção adotada pela maioria das empresas pesquisadas $(52,6 \%)$, e a opção da livre escolha estava presente em cerca de $64 \%$ delas. ${ }^{106}$

\footnotetext{
106 A pesquisa Ciefas/2000 mostrou que a prestação de serviços exclusivamente por credenciamento era a opção para 35\% das empresas; a combinação credenciamento/livre-escolha, para 45\%.
} 
A estrutura de atendimento da medicina de grupo compõe-se de serviços próprios e credenciados, estes progressivamente predominantes. Em 1988, cerca de $64 \%$ das empresas de medicina de grupo contratavam serviços e apenas $36 \%$ tinham serviços próprios. Atualmente, a rede própria de serviços é extremamente reduzida em relação à credenciada. Em 2001, para 250 hospitais próprios a medicina de grupo contava com 3.860 hospitais credenciados em todo o país (93\% do total), possuindo 23.500 leitos próprios e $354 \mathrm{mil}$ credenciados disponíveis. Os médicos credenciados correspondiam a mais de $80 \%$ do total de integrantes da rede de atendimento (Abramge, 2002).

As cooperativas médicas prestam serviços ambulatoriais utilizando os consultórios de seus cooperados (95.968, em 2002) e credenciam outros prestadores de serviços (hospitais, laboratórios, centros de diagnose), contando também com uma pequena rede de serviços próprios - apenas $1 \%$ do total de hospitais.

Essas diferentes combinações garantem um mercado consumidor de serviços de saúde que se apóia em uma rede privada de serviços de saúde que vende serviços para diferentes clientes: empresas (diretamente), medicina de grupo, cooperativas médicas, seguradoras ou consumidores individuais, além da clientela dos serviços públicos de saúde, uma vez que, em grande parte, a assistência pública, particularmente a hospitalar, é dependente dos prestadores privados, dos quais também compra serviços. Entretanto, embora o prestador, médico ou hospital, possa ser o mesmo, convivem no mesmo espaço tabelas de remuneração e modalidades de cobertura diferenciadas, que se traduzem em tratamento também diferenciado, dependendo da forma de acesso do cliente.

Um indicador dos interesses econômicos constituídos ao longo da trajetória da assistência médica supletiva é a evolução do seu faturamento, que expressa o volume de recursos movimentados. À época de elaboração da Constituição brasileira, quando foi criado formalmente um sistema de saúde público universal, o faturamento do conjunto dos segmentos que compõem a assistência privada já era próximo de US\$ 2 bilhões. Ao final da década de 90 , período de implantação do sistema público, o faturamento já atingira aproximadamente US $\$ 14$ bilhões, acusando crescimento superior a 300\% no período de implantação do SUS (Tabela 7). Em 2001, o faturamento apenas das 
operadoras comerciais de planos de saúde, excluindo-se a autogestão, foi equivalente a dois terços da execução orçamentária do Ministério da Saúde, a qual atingiu cerca de $\mathrm{R} \$ 26$ bilhões, enquanto a movimentação financeira da medicina de grupo, de cooperativas médicas e seguradoras ficou em torno de $\mathrm{R} \$ 17$ bilhões. Isso faz com que a assistência à saúde supletiva se configure como uma atividade econômica relevante e extremamente competitiva, em torno da qual gravitam diversos interesses, entre eles os relativos às operadoras de planos de saúde, aos prestadores de serviços - profissionais de saúde, instituições hospitalares e clínicas -, às empresas empregadoras e aos usuários.

Todos esses agentes se relacionam com o setor público de diferentes maneiras, em razão não apenas da necessidade de enquadramento legal, mas dos diferentes vasos comunicantes que se estabelecem entre a assistência pública e a privada. Para exemplificar, cabe lembrar que importantes organizações públicas mantêm alguns dos principais sistemas de autogestão, sendo que o maior deles tem como beneficiários os funcionários do Ministério da Saúde. Além do mais, ambos os sistemas são alicerçados, em grande parte, sobre a mesma rede privada prestadora de serviços, cuja fonte de recursos provém tanto do setor público quanto do privado.

Outra modalidade de articulação compreende as formas privilegiadas de acesso ao sistema público pelos usuários de planos privados que transitam de um sistema para outro sempre que o sistema público ofereça vantagens comparativas, principalmente para as operadoras de planos, que em muitos casos transferem seus clientes para o sistema público quando os procedimentos médicos necessários são mais onerosos. A convivência de atendimentos diversificados em razão da vinculação a formas diversas de assistência no âmbito da mesma rede prestadora favorece também a 'dupla cobrança', ou seja, do SUS e do plano privado, por parte do prestador. Esse trânsito é favorecido pelo fato de também os profissionais médicos, na maior parte das vezes, terem vários vínculos profissionais, podendo ser tanto empresários do setor (donos de hospitais ou de operadoras) quanto funcionários públicos ou conveniados às várias modalidades de operadoras de planos de saúde. A universalização formal da assistência pública com a dualidade real da assistência favorece essas articulações perversas que, por um lado, favorecem os cidadãos que têm a dupla cobertura, por isso mesmo costumam ter acesso privi- 
legiado ao sistema público, e, por outro, fazem recair sobre o SUS o ônus pela assistência de maior custo, cuja contrapartida lógica é a inviabilização da ampliação do acesso ao sistema público para os mais pobres, que costuma ser defendido por muitos dos agentes do mercado. O resultado é o aprofundamento da desigualdade de acesso.

\section{As Entidades de Representação de Interesses}

A descrição dos diversos segmentos que compõem a assistência à saúde supletiva evidencia a constituição de um conjunto de agentes - públicos e privados - de natureza complexa e heterogênea. Apesar de, na prática, a partir dos anos 90, a assistência prestada de forma privada tenha se tornado semelhante em muitos aspectos, em decorrência da interpenetração dos diversos segmentos, lucrativos ou não, como qualquer outro mercado, a competição e a busca da defesa dos próprios interesses caracterizam a assistência supletiva. De origem diferenciada, os diversos segmentos constituíram entidades representativas de seus interesses, cujo surgimento em momentos históricos distintos reflete os principais embates ou interlocutores com os quais tinham que se confrontar na tentativa de influenciar o processo decisório, tanto no âmbito governamental quanto privado.

$\mathrm{Na}$ condição de pioneira no mercado de assistência à saúde de caráter lucrativo, a medicina de grupo precocemente organizou entidades representativas para defender seus interesses. Já em 1966, foi criada a Associação Brasileira de Medicina de Grupo (Abramge). Posteriormente, em 1987, criou-se o Sindicato Nacional das Empresas de Medicina de Grupo (Sinamge) e, em fevereiro de 1990, o Conselho Nacional de Auto-Regulamentação das Empresas de Medicina de Grupo (Conange). As três entidades formam o 'Sistema Abramge/Sinamge/Conamge', com sede em São Paulo.

Os objetivos da criação da Abramge, ainda no início da constituição dos grupos médicos, explicitamente eram: organizar, regular e defender as empresas privadas que já estivessem atuando ou que viessem a se organizar; e propagar e incentivar o desenvolvimento da atividade. Sua criação se deu em São Paulo, berço dos grupos médicos, e coincide com o estabelecimento dos 
primeiros convênios da Previdência Social com as empresas para a prestação de assistência. Desde a criação, a principal atuação da Abramge foi como interlocutora dos grupos médicos perante as autoridades governamentais. A criação do Conamge teve como objetivo auto-regulamentar a atividade da medicina de grupo, como reação à disposição governamental de regulamentar o mercado de assistência supletiva. Após a efetiva regulamentação governamental, essa entidade perdeu a sua finalidade original.

As cooperativas médicas foram a segunda modalidade a se organizar, ainda na década de 70. Embora usem a mesma logomarca, as cooperativas são independentes umas das outras e organizadas no nível dos municípios, constituindo as Unimeds singulares. Nos anos 70, foram organizadas as federações estaduais, reunindo as singulares respectivas, e em 1975 foi criada a Unimed do Brasil, como uma confederação nacional reunindo as federações, com o objetivo de integrar, orientar e coordenar as atividades do Sistema Unimed, além de constituir-se em um espaço para difundir as idéias sobre o cooperativismo médico (Unimed Brasil, 2002).

Nos anos 80, foi a vez dos sistemas de autogestão, cuja primeira entidade representativa foi a Associação de Serviços Assistenciais de Saúde Próprios de Empresas (Asaspe), criada em São Paulo em 1980. ${ }^{107}$ Durante essa década, foram criadas entidades similares, adotando o mesmo nome, nos estados de Minas Gerais, Ceará e Espírito Santo. Em 1984, foi fundada a Associação Brasileira de Serviços Próprios de Saúde de Empresas (Abraspe), com o objetivo de integrar as entidades estaduais, com as características de uma federação das Asaspes, mas que não deu resultado, sendo fundida em 1995 com a Asaspe de São Paulo. ${ }^{108}$ A Abraspe congregava entidades de empresas públicas e privadas até 1990, quando foi criado o Comitê de Integração das Entidades Fechadas de Assistência à Saúde (Ciefas), com a pretensão de representar as empresas estatais e públicas, as entidades sindicais, as caixas e as funda-

107 “O termo 'serviços próprios de empresas' era usado pelo governo na época para caracterizar as empresas que ofereciam planos de saúde a seus empregados e que, por isso, podiam fazer algumas deduções do recolhimento à Previdência Social" (Ciefas, 2000: 49).

108 A Abraspe permanece hoje como uma entidade que agrega sistemas de autogestão de empresas privadas do estado de São Paulo, equivalendo a uma Asaspe. Outras entidades regionais foram criadas nos anos 80 em Pernambuco, Paraná e Bahia, cuja maioria das empresas filiadas foi incorporada ao Ciefas após sua criação. 
ções formadas por funcionários públicos federais, constituindo, desde sua origem, como uma entidade de representação nacional. Com o esvaziamento da Abraspe, gradativamente o Ciefas foi absorvendo também a representação dos sistemas de autogestão de empresas privadas ao longo dos anos 90 , agregando, em 2000, 140 organizações, entre públicas e privadas (Ciefas, 2000). O objetivo principal da criação dessas entidades foi representar os interesses da autogestão diante das instâncias governamentais, mas principalmente das entidades de classe da área da saúde, dos representantes dos prestadores de serviços, como as associações médicas e de hospitais, e do Colégio Brasileiro de Cirurgiões. A meta básica consistia em uniformizar os procedimentos e a atuação perante os prestadores, particularmente quanto à padronização das tabelas de preços dos serviços médicos. Em razão das origens diferentes, as duas entidades tinham perspectivas bastante distintas em relação à assistência que traduziam as diferenças entre organizações públicas e privadas. ${ }^{109}$ As ações principais dessas entidades são dirigidas para as negociações com os prestadores de serviço, buscando principalmente a redução de preços. Mas em razão das condutas diferenciadas, essa ação conjunta se viu, muitas vezes, obstaculizada.

A criação do Ciefas coincide com a deflagração de séria crise entre prestadores e sistemas privados de saúde em torno principalmente da questão dos valores pagos. Até então, para pagamentos dos serviços, vinham sendo adotados os critérios de remuneração definidos pela AMB, situação que passou a ser questionada a partir de meados da década de 90 nas negociações com os provedores, em uma conjuntura em que as empresas se viam obrigadas a grandes contenções de custos. ${ }^{110} \mathrm{O}$ primeiro resultado da atuação conjunta foi em 1993, quando o Ciefas conseguiu um acordo com a AMB para a produção de uma tabela de honorários consensual. Ao mesmo tempo que ampliava sua atuação perante os prestadores, o Ciefas passou a participar das

\footnotetext{
109 "A maneira de fazer pública e a maneira de fazer privada são completamente diferentes. Por exemplo: na hora de negociar, o Ciefas tinha uma tabela de taxas que chegou a ter setenta taxas além da tabela da Asaspe. Além de pagar mais, o Ciefas tinha muito mais dificuldades de cortar coisas ou prestadores" (entrevista com Virgílio Baião, presidente da Asaspe-MG, em julho de 2002).

110 "As oscilações da política governamental, crise econômica, inflação galopante, arrocho salarial e 'enxugamento' de gastos públicos das estatais eram preocupações que agitavam grande parte do segmento da autogestão em saúde, pressionando não só pela caótica realidade como pela organização e pressão de empregados e funcionários" (Ciefas, 2000: 53-54).
} 
discussões governamentais relativas à saúde suplementar. A organização dos sistemas de autogestão conseguiu enfraquecer os prestadores de serviços, particularmente no esvaziamento da força da tabela da AMB, cuja pretendida obrigatoriedade de utilização passou a ser considerada pelo governo como tentativa de formação de cartel. Com base nessa interpretação, que resultou na sua proibição, a tabela tornou-se apenas um referencial de preços, situação que fortaleceu os compradores de serviços, que passaram a negociar tabelas próprias. ${ }^{111}$

Mais recentemente, deu-se a unificação das entidades representativas da autogestão, com a criação, em novembro de 2002, da União Nacional das Instituições de Autogestão em Saúde (Unidas), resultado da união do Ciefas e da Abraspe. A Unidas representa 150 organizações, públicas e privadas, que cobrem cerca de cinco milhões de assistidos e cujo desafio principal é conseguir tratamento diferenciado para o segmento da autogestão na regulamentação governamental.

Os órgãos de representação das seguradoras são a Federação Nacional das Seguradoras (Fenaseg), criada em 1951 e reconhecida oficialmente em 1953, e a Comissão Técnica de Seguro Saúde, de 1969. Apesar de sua atuação relativamente recente no ramo saúde, a entidade já tem larga experiência de organização e de atuação perante o Poder Público, tanto no âmbito do Executivo federal quanto no Legislativo, com uma ação direcionada a diminuir o escopo da ação governamental. Entre seus objetivos, recentemente traçados, estão a "ampliação do espaço de atuação política, de modo mais efetivo junto ao Poder Público, visando à redução da presença do Estado no mercado, a desregulamentação, a autonomia do setor, a efetiva quebra de monopólios (...)" (Fenaseg, 2002).

111 Até o ano de 2007 tramita na Câmara dos Deputados um projeto de lei que "autoriza as entidades representativas dos profissionais de saúde a elaborarem tabela de referência que, uma vez aprovadas pelo Conselho Nacional de Saúde, passam a servir como base de negociação de honorários" (entrevista com o deputado federal Rafael Guerra em maio de 2002). De acordo com esse deputado, após ter sido aprovada na Comissão de Seguridade Social e Família, o projeto foi encaminhado para a Comissão de Economia, na qual o lobby das seguradoras e dos planos de saúde é mais forte, de forma que o projeto não entrou em tramitação. Essa proposta do deputado, juntamente com outra de sugerir ao Ministério da Saúde a autorização de pagamento de complementação de honorários em caso de utilização de acomodações especiais nas internações, sugere a retomada da situação vigente na década de 80 , que favorecia os profissionais e os incentivava a atender os clientes do SUS, na medida em que tinham seus honorários majorados, e ainda tendo como referência a tabela da AMB. 
Pelo lado dos prestadores de serviço, cabe destacar a representação dos hospitais que, como a Abramge, têm sua origem estreitamente ligada às políticas públicas. Concomitantemente à expansão da assistência médica previdenciária, em 1966, mesmo ano de criação da representação da medicina de grupo, foi criada a Federação Brasileira dos Hospitais Credenciados pela Previdência Social, que se transformaria na Federação Brasileira dos Hospitais (FBH). O nome originário por si só já demonstra a relação com a Previdência Social, maior compradora dos serviços hospitalares e por intermédio da qual a política de assistência garantiu a expansão do mercado para serviços hospitalares. Essa marca de origem mostra os objetivos da entidade, que busca desde sua criação influenciar a política de assistência médica e, principalmente, o valor pago aos serviços hospitalares pelo sistema público de saúde, ainda hoje o principal comprador desses serviços. Em 2003 possuía 12 entidades federadas, correspondentes às associações de hospitais de estados. No Legislativo, sua atuação se faz principalmente na Comissão de Seguridade Social e Família e diretamente com os parlamentares, contando com uma assessoria parlamentar para o acompanhamento de projetos no Congresso Nacional. No Executivo, tem acesso ao ministro da Saúde e assento no Conselho Nacional de Saúde. Apesar de assumir uma postura liberal, de antiestatização da saúde, reconhece que o sistema público é o maior financiador de saúde no país, além de ser a principal porta de entrada para os hospitais. Para barganhar maior remuneração para os serviços hospitalares, utiliza como argumento o direito constitucional de acesso a serviços de saúde, para cuja garantia o papel do setor privado é fundamental. Diante da insatisfação com valores e prazos de pagamento, os hospitais costumam utilizar-se do expediente de paralisação do atendimento à clientela do SUS, além do recurso a ações judiciais, visando receber valores maiores pelos serviços prestados ao sistema público. $\mathrm{Na}$ análise deste segmento, o sucateamento da assistência pública é decorrência dos baixos valores das tabelas de remuneração de procedimentos adotada pelo SUS para pagamento da rede médico-hospitalar, imputando a necessidade de reajustes à necessidade de transformar o contexto de saúde da população. ${ }^{112}$

112 De acordo com matéria publicada no Jornal FBH (ano 2, no 15, dez. 2000-jan. 2001): "Números e percentuais, porém, bem como informações sobre reajustes concedidos ou não, variam conforme o interlocutor. Segundo a FBH, a defasagem, que começou com a implantação do Real em 1994, já passa de 100\%. O Fipe Saúde mostra que entre julho de 1994 e maio de 1999, os custos na área aumentaram em 109\%. Nesse mesmo período, entretanto, foi dado um reajuste de somente $25 \%$. A diferença observada representa quase $90 \%$ em desfavor da rede." 
A insatisfação com a remuneração, muitas vezes, conduz a acirramentos na relação governo/prestadores de serviços, particularmente com o governo federal, a quem cabe a definição da tabela de pagamento. Atualmente, as principais reivindicações dos hospitais ao SUS, além dos valores dos procedimentos, são: reorganização de uma política para o setor, o que inclui linhas de financiamento especiais para os hospitais; definição de regras do relacionamento jurídico entre comprador e prestador de serviço; tratamento igualitário entre o segmento filantrópico e o lucrativo (denominado pela FBH como privado); implantação de mesa de negociações permanentes no âmbito do Ministério da Saúde, com a participação da FBH; e, ainda, a sugestão de alteração do princípio da gratuidade do SUS mediante a cobrança complementar ao usuário. ${ }^{113}$ A relação com os segmentos da assistência supletiva é, no mesmo sentido, a de negociar preços para os serviços prestados, sendo que a organização posterior de entidades representativas dos segmentos privados compradores de serviços se deu principalmente em razão da necessidade de negociar preços de forma conjunta com os prestadores. A pressão por rebaixamento dos valores de remuneração dos serviços hospitalares por parte dos diversos segmentos da assistência à saúde supletiva tem forçado os hospitais a buscarem rebaixamento de custos em um mercado que sofre limitações na capacidade de expansão da remuneração. Como alternativa, tanto ao sistema público quanto aos planos de saúde, a Federação de Hospitais vem se organizando no sentido de criar um Fundo Mútuo de Assistência à Saúde, buscando captar uma clientela do SUS diretamente para os hospitais privados.

Entre os prestadores de serviço, é a categoria médica que tem a mais longa experiência de organização, embora sua representação se pulverize em diferentes instituições, como a Associação Médica Brasileira (AMB), o Conselho Federal de Medicina (CFM) e os sindicatos, reunidos na Federação Nacional dos Médicos (Fenam) e na Confederação Médica Brasileira (CMB). Criada

\footnotetext{
3 Literalmente, assim se expressou o presidente da FBH em ofício encaminhado ao secretário executivo do Ministério da Saúde em fevereiro de 2001, no bojo de uma crise entre os hospitais e o ministro da Saúde, José Serra, que, em declaração pública, tachara de 'malandros' os portadores das reivindicações dos hospitais por aumentos nas tabelas: "Não se trata aqui de um ultimatum, posto que saberemos continuar parceiros se o Ministério da Saúde admitir que não dispõe de orçamento para garantir a gratuidade do atendimento a toda a população e souber reconhecer nossas dificuldades, auxiliando na mobilização positiva da sociedade para a busca de fontes alternativas de recursos, inclusive com a reintrodução da cobrança complementar mediante regras claras" (Jornal FBH, ano 2, no 15, dez. 2000-jan. 2001).
} 
na década de 50, assim como os Conselhos Regionais de Medicina, a Associação Médica Brasileira (AMB) aumentou sua presença política a partir de 1964, quando assumiu posição contrária à ampliação da intervenção do Estado na assistência médica, postura que marcou o período. Sua atuação em conjunto com alguns sindicatos médicos nesse mesmo período voltou-se também contra o empresariamento da medicina, desencadeando uma oposição ferrenha à atuação das empresas de medicina de grupo.

A defesa da prática liberal sempre caracterizou a AMB, embora ao longo dos anos 60 e 70 a categoria tenha presenciado a alteração da sua inserção profissional, passando cada vez mais o trabalho assalariado a substituir a medicina liberal, prestada diretamente pelo médico em seus consultórios. Nesse percurso, a atuação médica acompanha o desenvolvimento da assistência à saúde no país - ao assalariamento inicialmente nas instituições governamentais, segue-se a inserção no mercado de trabalho vinculado à medicina de grupo. Em defesa da prática médica autônoma surgem as cooperativas médicas, inaugurando outra forma de trabalho, que associou a autonomia nos consultórios à introdução dos planos de saúde privados, individuais ou empresariais controlados e comercializados pelos médicos. Ao assalariamento seguiu-se também o fortalecimento da organização sindical dos médicos, que passaram a adotar as práticas dos trabalhadores, inclusive o instrumento das greves.

No final dos anos 70, sucederam-se vários movimentos grevistas voltados para as condições de trabalho nas instituições públicas e também para a regulamentação do trabalho dos médicos residentes. Essas greves tiveram a característica de incorporar, além das demandas corporativas, propostas de transformação da política de saúde e de democratização do país. Nesse momento, os médicos se uniram aos movimentos gerais da sociedade pela mudança do regime político.

Nos anos 80, após a democratização do país, a atuação dos médicos se volta novamente para as questões corporativas. Em geral, as principais questões que caracterizam a atuação da categoria médica ao longo do tempo, além daquelas mais imediatas, relativas à remuneração do trabalho médico, referem-se à crítica ferrenha à exploração do trabalho médico por terceiros, entendidos como as empresas de medicina de grupo; à defesa da autonomia profissional, que tem como foco a contestação dos parâmetros e limites apresentados pelos planos de saúde no sentido de restringir os procedimentos 
realizados com o intuito de diminuir custos - vinculada a essa questão, defendem a disponibilidade irrestrita dos meios de diagnóstico; à defesa da liberdade de escolha do médico por parte dos usuários de serviços médicos, passando a defender o 'credenciamento universal' dos médicos por todos planos de saúde; e, mais recentemente, à crítica à expansão de escolas de medicina, questionando a ampliação irrestrita do contingente de médicos, com base em um discurso de defesa da qualidade da formação médica.

De uma ação voltada principalmente para o setor público como principal empregador da categoria, a atuação dos médicos passou a se dirigir para os planos de saúde privados, com o aprofundamento do exercício da profissão mediante a prática dos credenciamentos comuns às distintas modalidades de assistência privada. Nessa relação com as instituições que comercializam planos de saúde ou gerenciam sistemas próprios, o embate tem se dado com base naquelas questões listadas, em uma situação em que o médico cada vez mais se torna dependente dos convênios. ${ }^{114} \mathrm{~A}$ relação com as cooperativas tem também se tornado conflituosa, na medida em que, na prática, elas funcionam de forma similar, apresentando os mesmos limites à atuação autônoma dos médicos cooperados; além do mais, os valores dos serviços médicos, muitas vezes, são mais baixos do que os pagos pelas outras modalidades de planos de saúde privados. ${ }^{115} \mathrm{O}$ fortalecimento das ações conjuntas dos planos privados com base em sua organização tem enfraquecido o poder auto-regulatório da categoria médica, particularmente na questão dos valores a serem pagos pelos serviços que prestam. O conflito relativo às tabelas de honorários é a face mais visível desse embate, embora esteja em jogo a tão defendida autonomia médica. Visando recuperar seu poder, a categoria tem discutido a formação de uma entidade que unifique sua atuação, diante da pulverização em diferentes formas organizativas. A proposta de criação da Ordem dos Médicos se insere nessa perspectiva como forma de fortalecimento da categoria.

$\overline{114}$ A pesquisa "Perfil dos médicos no Brasil" (Fiocruz/CFM, 1995) mostrou que cerca de 70\% dos médicos trabalhavam no setor público, mas cerca de $80 \%$ participavam de convênios médicos, sendo que $75,6 \%$ deles tinham até três atividades, e quase $25 \%$ mais de três.

115 Depoimento do então presidente do Sindicato dos Médicos de Minas Gerais, Ricardo de Menezes Macedo, é sugestivo: "Acontece que as cooperativas viraram empresas. E o lucro é o principal princípio de uma empresa. (...) O discurso cooperativo não existe mais nem mesmo dentro das próprias cooperativas. (...) Mas a remuneração do médico anda péssima e a discussão política praticamente inexiste no cooperativismo médico" (Sinmed-MG, 2000: 75). 
O desenvolvimento da assistência à saúde privada constituiu relações complexas e, muitas vezes, conflituosas entre os seus diversos segmentos, particularmente entre as organizações que operam ou comercializam planos de saúde e os prestadores de serviços. Mas as conexões alcançam também o setor público, na medida em que grande parte dos prestadores de serviços, médicos ou hospitais, atua tanto no setor público quanto no privado. O conflito de interesses entre os atores que formam esse cenário se expressa na constituição de suas organizações e torna a arena da saúde um espaço competitivo, complexo e até contraditório ao colocar em oposição, por exemplo, o mesmo profissional, em razão de formas diferentes de inserção na assistência à saúde.

\section{Síntese}

A análise da trajetória da assistência privada desenvolvida neste capítulo permitiu constatar os efeitos de feedback da política de saúde segundo uma dupla perspectiva. Em primeiro lugar, evidenciou os mecanismos por meio dos quais essa política, voltada para a assistência à saúde de caráter público, favoreceu o surgimento de várias modalidades institucionais de assistência privada e a expansão de outras que já existiam de forma ainda pouco expressiva. Em segundo, permitiu identificar os efeitos institucionais do crescimento das formas privadas de assistência, vis-à-vis ao da assistência pública. Entre estes, os mais importantes foram: a constituição e/ou fortalecimento de diversos atores ou agentes do mercado, como prestadores, operadoras e usuários, e, em razão disso, a configuração de interesses; o estabelecimento de regras e procedimentos relativos à forma de prestação da assistência, mecanismos de acesso e de diferenciação, os quais estruturaram comportamentos e moldaram preferências; e, como conseqüência desses efeitos anteriores, o crescimento da assistência privada, que influenciou o processo político ao constituir a arena política da saúde, na qual, em razão do formato assumido pela política, configuraramse estratégias considerando os objetivos básicos de, por um lado, garantir recursos públicos, de forma direta ou indireta, e, por outro, obter ou preservar regras favoráveis, mas principalmente a ausência de regras para a expansão do mercado de assistência à saúde. 
A descrição das dimensões e características do segmento privado e dos atores vinculados a ele mostrou a sua relevância econômica e política e a institucionalização de regras e comportamentos difíceis de serem mudados, tornando outras opções pouco prováveis. É nessa medida que fornece elementos para interpretar os processos de reforma da política de saúde nas décadas de 80 e 90 , quando se tornaram evidentes os limites que esses efeitos das políticas anteriores apresentaram para as reformas.

Um primeiro aspecto a ser ressaltado é que a gênese e a expansão das formas privadas de assistência à saúde estão diretamente ligadas às relações de trabalho na forma de planos de saúde coletivos. Do mesmo modo que a assistência de caráter público se inicia no âmbito da Previdência Social, como um benefício vinculado à inserção no mercado de trabalho, também os planos e seguros de saúde privados, na sua grande maioria, surgem e se desenvolvem subordinados a contratos de trabalho, como benefício trabalhista concedido por algumas empresas, com a participação direta ou indireta do Estado e como conseqüência de decisões governamentais que favoreceram a constituição de determinados arranjos e práticas.

É verdade que desde as primeiras décadas do século XX existiam iniciativas empresariais no sentido de prover algum tipo de assistência médica aos empregados, mesmo que muitas vezes restrita à medicina do trabalho, e que eram independentes da ação governamental e de qualquer política regulatória. As mais importantes experiências iniciaram-se a partir dos anos 40, inclusive voltadas para segmentos que eram cobertos pela assistência prestada pelos IAPs, como os funcionários do Banco do Brasil e da Caixa Econômica Federal. Mas será apenas a partir dos anos 60 que irá se expandir a assistência à saúde no âmbito das empresas, privadas e públicas, o que se fará com base nas políticas públicas que reforçariam as iniciativas empresariais, estimulariam a constituição de novos atores no cenário da assistência privada, como a medicina de grupo e as cooperativas médicas, e incorporariam outros mais antigos, como as seguradoras.

Isso foi feito por meio de diversos mecanismos. O primeiro deles foram os convênios-empresa, a partir dos quais foram dados incentivos governamentais para que as empresas se encarregassem da assistência médica com financiamento público, pelo menos parcial, para seus empregados. A criação 
dos convênios-empresa foi uma decisão que favoreceu a expansão da assistência privada, não tanto pelo volume dos convênios estabelecidos com a participação da Previdência Social, mas pela institucionalização e legitimação de uma prática empresarial ainda restrita antes deles. É claro que fatores internos às empresas, como a necessidade de redução do absenteísmo, o aumento da produtividade e o esforço para aumentar a competitividade na disputa por quadros mais qualificados foram (e são) fatores importantes na decisão de conceder assistência aos empregados. Mas o apoio governamental, inicialmente de forma direta, mediante subsídios financeiros, e posteriormente de forma indireta, por meio de mecanismos tributários, foi fundamental para sua institucionalização e legitimação. Na mesma época, incentivada pelos convêniosempresa, constituiu-se a assistência privada independente do financiamento direto e da supervisão pública, mas também vinculada às empresas e, portanto, garantindo assistência a partir da inserção no mercado de trabalho não apenas formal, mas privilegiado, uma vez que era limitada às grandes empresas, principalmente da região Sudeste e, sobretudo, do estado de São Paulo.

Apenas a partir dos anos 80 , a assistência privada irá se desenvolver fora do âmbito das empresas empregadoras por intermédio dos planos de saúde contratados individualmente. Similares no caráter privado, esse tipo de plano será de natureza diferente ao engendrar relações tipicamente de consumo entre o beneficiário e a operadora que o comercializa. A inserção nos planos de saúde privados se dará entre os estratos de maior renda e vai substituir, em parte, a prática liberal que prevalecia até os anos 70, que foi se inviabilizando com o crescimento dos custos da assistência médica. Esse comportamento foi incentivado pela política tributária, mediante o mecanismo de dedução fiscal, e facilitado pelas estratégias agressivas de comercialização de planos privados em um mercado, até o final da década de 90 , sem qualquer regulamentação governamental. De forma similar, também o custeio da assistência no âmbito das empresas foi indiretamente assumido, pelo menos em parte, pelo governo e pela sociedade em geral, na medida em que passou a ser computado como despesa operacional, não integrando o rendimento tributável das empresas e sendo repassado aos preços dos produtos ou serviços produzidos.

Outras decisões públicas no sentido de viabilizar e ou desafogar a assistência pública tiveram o efeito de fortalecer a assistência privada e de consoli- 
dar os interesses associados a ela. Entre elas, foi fundamental a prévia opção por comprar serviços privados em vez de desenvolver uma rede própria de serviços de saúde, tendência que caracterizou a expansão da assistência pública. Essa opção teve o efeito de fortalecer os profissionais e as instituições privadas prestadoras de serviços e suas representações de interesses. A pressão que exerciam por remunerações mais altas em situação de impossibilidade de atendimento pelo Poder Público, em razão de uma crise da Previdência Social, em parte como decorrência do alto custo do modelo de compra de serviços, vai levar a uma seqüência de decisões de conseqüências perversas para o atendimento público, favorecendo, em contrapartida, a opção dos usuários pela assistência privada.

Um conjunto de decisões governamentais relativas à remuneração dos serviços hospitalares, ao mesmo tempo que atendia à pressão dos prestadores de serviços e acomodava as demandas dos usuários por atendimento de melhor qualidade, aprofundou o hiato entre a assistência pública e a privada. Por meio delas, o governo permitiu o pagamento de complementação pelos atendimentos hospitalares quando em acomodações especiais, isto é, diferentes das custeadas pelo Poder Público. Essa decisão teve como efeito a deterioração do atendimento prestado em acomodações não-especiais, ao mesmo tempo que incentivou o desenvolvimento dos planos privados, uma vez que estes eram autorizados a efetuar essa complementação. Diversas decisões nesse sentido tiveram o efeito de definir o comportamento dos atores privados (prestadores de serviços, usuários, operadoras de planos de saúde e sistemas de autogestão): a) usuários que tinham capacidade de assumir os gastos foram incentivados a optar por acomodações especiais a custo mais baixo, uma vez que parcela desse custo era assumida pelo setor público; b) hospitais reduziram as acomodações tipo enfermaria para estimular o atendimento especial, mais lucrativo, num momento em que a remuneração governamental estava muito aviltada; e c) compradores de serviços - sistemas de autogestão, cooperativas ou medicina de grupo -, pressionados pelos custos dos atendimentos, passaram a se organizar com o objetivo de negociar de forma coletiva com os prestadores e rebaixar os preços dos serviços de saúde, quando a participação governamental no pagamento dos serviços hospitalares se tornara pouco significativa. Dessa forma, as medidas governamentais contribuíram para a 
explicitação do conflito de interesses entre entidades médicas e operadoras de planos de saúde, em razão do controle de custos, e, ainda, para desfazer o vínculo da assistência privada com a pública. Nos anos 80 , a assistência privada deixa de ser complementar para se tornar suplementar, passando a ter seu desenvolvimento de forma autônoma, em relação tanto ao financiamento quanto à forma de captação da clientela. No final da década, outra decisão governamental favoreceu a entrada das seguradoras no ramo saúde, ao lhes ser autorizado fazer o referenciamento de profissionais e instituições de saúde, o que lhes permitiu baixar custos e disputar o mercado privado com a medicina de grupo e com as cooperativas médicas.

As conseqüências maléficas da inexistência de uma política afinada concretamente com a meta formal de publicização da assistência se traduziram na deterioração da qualidade da assistência pública, reforçando a opção pela assistência privada para os trabalhadores por parte das empresas e, posteriormente, pelos indivíduos isoladamente. A própria prática governamental incentivou a ampliação das ações privadas e reforçou a diferenciação, revelando a inexistência de um projeto efetivo de universalização e equalização da assistência. Expressão emblemática disso foi a existência no âmbito da própria instituição previdenciária, encarregada da política de saúde, de uma assistência diferenciada para seus funcionários. Desta forma, a expansão da assistência supletiva nos anos 80 não foi um processo paralelo e independente das políticas públicas; ao contrário, foi no bojo da crise da assistência pública e sob a pressão dos interesses privados já constituídos, particularmente dos prestadores de serviço, que se definiram medidas governamentais que favoreceram aquela expansão e constituíram um arranjo institucional crivado de contradições. As ações governamentais contribuíram de forma decisiva para a institucionalização e legitimação da opção pela assistência privada e, de forma indireta, retiraram recursos públicos que poderiam ser canalizados para a assistência pública, contribuindo para seu mau desempenho. Na forma de uma espiral, a seqüência de decisões e ações foi reforçando as opções privadas.

A dinâmica das decisões governamentais e das ações privadas - estas últimas em grande parte como resposta a estímulos governamentais, no caso das empresas empregadoras ou operadoras de planos de saúde, ou como alternativa de assistência diante da deterioração da assistência pública, ou ao 
encarecimento da medicina liberal, no caso dos usuários - foi constituindo o arranjo institucional da assistência à saúde no Brasil. Tal arranjo assumiu um formato híbrido - público e privado -, integrando agentes variados, articulados por um conjunto de regras, inicialmente definidas prioritariamente pelo Poder Público, que era o agente regulador, mesmo que isso se fizesse de forma precária, em razão da captura do governo pelos interesses privados, particularmente dos prestadores de serviços. Em um segundo momento, esse espaço de regulação foi sendo ocupado e disputado por agentes privados representantes do segmento da assistência supletiva, concomitantemente ao processo de autonomização em relação ao setor público.

Esse arranjo institucional vai se caracterizar pela complexidade, com várias organizações diferenciadas disputando o mercado de saúde, tanto do lado da oferta de serviços como do lado da captação de clientes, bem como pelos diversos mecanismos de articulação entre eles. Na sua trajetória, a assistência privada constituiu identidades e clivagens sociais em virtude da forma de inserção na atividade e de concepções diversas sobre a prática médica, a mais emblemática sendo o conflito entre a medicina de grupo e as cooperativas médicas. Conflitos de interesse entre prestadores e compradores de serviço, por sua vez, definiram preferências similares entre os agentes na mesma posição, aproximando as estratégias com vistas ao controle de preços dos serviços de saúde. O imbricamento de interesses e a similaridade das estratégias acabam por tornar menos nítidas as diferenças entre os diversos formatos assumidos historicamente pela assistência privada em aspectos como a forma de captação de clientela, a definição dos padrões da assistência, os mecanismos de controle de preços e custos e a forma de articulação com os prestadores de serviços. Neste último caso, destaca-se o fato de partilharem a mesma rede de serviços, inclusive com o setor público, no que diz respeito à rede hospitalar.

A formação das organizações de interesses dos agentes desse mercado reflete ações em cadeia em razão das alterações da assistência e do surgimento de novos agentes. Se a Abramge tem sua origem vinculada à política dos convênios/empresa, as Unimeds se organizam para se contrapor à medicina de grupo e garantir o controle dos serviços médicos pelos próprios médicos, e a Abraspe e o Ciefas são o resultado da organização dos compradores de serviços com o objetivo principal de buscar o controle de preços, num 
momento em que a assistência privada já se tornara efetivamente independente da participação governamental e em contraponto às tentativas das organizações médicas de regular o mercado, particularmente os preços dos serviços. Nesse processo de autonomização, os próprios agentes do mercado assumem a regulação do setor.

Entre os interesses constituídos estão os dos beneficiários da assistência privada, particularmente os empregados das empresas e instituições públicas que administram ou contratam planos de saúde. Ao terem acesso a uma assistência diferenciada, passam a ser seus apoiadores, de forma explícita ou implícita. A institucionalização das formas empresariais de assistência privada torna esse benefício patronal um diferencial valorizado nas relações de trabalho e, de forma endógena ao contexto institucional da assistência e em razão das vantagens distributivas da política de saúde, configura a preferência pela assistência privada.

Esses diversos interesses que se constituem e se organizam ao longo das décadas de 60 a 80 manifestar-se-ão nos momentos cruciais de redefinição da política de saúde, como no processo constituinte e na regulamentação tardia da assistência privada, no final dos anos 90 . No próximo capítulo será analisada a reforma da política de saúde nos anos 80 , bem como sua implantação na década de 90 , cujas características vão refletir a configuração institucional das políticas anteriores. Nos dois processos, serão evidenciados, de um lado, a ação dos atores representando os interesses que constituíram e configuraram a arena da saúde e, de outro, a institucionalização dos comportamentos e das práticas ligadas à assistência privada que causaram constrangimentos a qualquer remodelação mais radical do sistema de assistência à saúde. 


\section{4}

\section{A Reforma da Política de Saúde: inovação e continuidade - 1975/2000}

Este capítulo analisa a reforma da política de saúde definida na Constituição de 1988, levando em conta os processos de formação, decisão e implementação da nova política. A interpretação desses processos considera como fatores explicativos cruciais os efeitos de feedback, ou o legado das políticas prévias que fizeram com que, mesmo em uma situação de rearranjos institucionais, se configurasse, de fato, um processo de inovação limitada, o qual se torna mais evidente no momento de implementação da reforma, embora o próprio texto constitucional já estabeleça a dualidade do sistema de saúde.

Mas se esses fatores são responsáveis pelos aspectos de continuidade da política de saúde, eles não explicam a ruptura institucional decorrente da reforma sanitária que foi de fato realizada. Dois fatores são considerados para a explicação da mudança, cada um deles com peso diferente. O primeiro e mais importante é a conjuntura política mais ampla, caracterizada pelo processo de democratização do país, que permitiu que novos atores, portadores de propostas transformadoras, participassem da arena política e se tornassem suficientemente fortes para influenciar o processo decisório. O segundo fator é a crise da política de saúde, em razão, principalmente, do esgotamento da capacidade de financiamento do modelo de assistência que prevalecia, de alto custo e baixa efetividade. A crise financeira contribuiu para ressaltar as inadequações do modelo assistencial, que se traduzia na crescente insatisfação de usuários, prestadores de serviço e trabalhadores de saúde. Entendendo que a relação entre crise e reforma não é mecânica, mas mediada por processos políticos 
por meio dos quais são definidas alternativas para o enfrentamento da crise, isso significa que ela pode desembocar em diferentes escolhas, na medida em que não existe uma única saída para a crise. Nessa perspectiva, considera-se que o movimento político-ideológico pela reforma sanitária soube construir uma proposta elaborada para a saúde, tirando proveito de uma conjuntura favorável a mudanças democráticas que incluíam a ampliação das políticas sociais, apresentando-a como a alternativa para a crise. Desta forma, no processo de mudança constitucional, o impacto das políticas prévias foi mediado pelo contexto político mais amplo de redemocratização do país e de ampliação dos direitos sociais.

Este capítulo tem, assim, uma dupla pretensão analítica: em primeiro lugar, explicar a ruptura institucional decorrente de um movimento em prol da reforma sanitária; em segundo, explicar as continuidades e/ou ambivalências que caracterizam o novo modelo institucional quanto ao aspecto específico da assistência à saúde. Se a ruptura é explicada pelo contexto de democratização e por uma situação de crise favorável a mudanças, a continuidade é atribuída à dependência de trajetória, de tal forma que os dois tipos de fatores explicativos, conjuntamente, fornecem uma explicação plausível para o formato híbrido público e privado - assumido concretamente pela assistência à saúde no Brasil.

Esse argumento analítico aqui adotado considera que as políticas de saúde, ao mesmo tempo que podem ser vistas como conseqüências da ação política (variáveis dependentes), também são potentes para explicar tanto o desenvolvimento político quanto as políticas posteriores (variáveis independentes). No primeiro caso, as mudanças na política de saúde que culminaram com as definições constitucionais podem ser vistas como resultado da ação política decorrente da emergência e organização de novos sujeitos políticos que, aproveitando-se de uma conjuntura favorável, foram bem sucedidos no processo de transformar uma comunidade epistêmica, organizada em torno de uma concepção de saúde, sociedade e atuação do Poder Público, em um grupo de ação política, para isso aglutinando aliados e interesses ao redor de uma proposta de reforma do sistema de saúde. No segundo caso, entendendo-as como variáveis independentes, as políticas de saúde estabelecidas desde os anos 60, por meio dos seus efeitos institucionais e do processo político, são responsáveis pelos elementos de continuidade da política de assistência à saúde 
que se expressam no próprio texto constitucional, mas principalmente na trajetória da assistência durante e após as mudanças no plano ideal-formal, ou seja: durante a formação, a decisão e a implantação da reforma.

Essa análise da reforma da política de saúde e da configuração institucional da assistência, que se consolidou com características de ruptura e continuidade em relação às políticas anteriores, permite validar a hipótese geral deste estudo, segundo a qual o formato institucional híbrido da assistência à saúde, apesar da definição constitucional de um sistema público, universal e único, é explicado, em grande parte, pelos legados das políticas prévias que limitaram as possibilidades de mudanças, em razão de seus efeitos sobre o conflito político, na definição de padrões de comportamento e na capacidade governamental, além de seus efeitos cognitivos.

Para desenvolver esses argumentos, o capítulo é dividido em três partes. Inicialmente, é feita uma análise do processo de formação da proposta de mudança da política de saúde, entendido como a constituição da agenda, a difusão de idéias, a elaboração de propostas inovadoras e a articulação política de diversos atores, visando influir no processo decisório. Desde meados dos anos 70 , foram se constituindo propostas alternativas para a assistência à saúde com base na crítica à política vigente que, por meio de várias medidas governamentais, aprofundava o 'modelo privatista', assim denominada a opção pela ampliação da assistência pública em razão da privilegiação da compra de serviços privados em detrimento da utilização e/ou expansão da rede pública. Na mesma época, expandia-se também a assistência privada de forma autônoma, embora contando com subsídios governamentais, diretos ou indiretos, conforme analisado nos capítulos anteriores. $\mathrm{O}$ baixo controle da rede privada e a captura da burocracia governamental pelos interesses dos prestadores apontavam como principais conseqüências desse modelo de política os altos índices de corrupção e o aumento dos gastos a patamares insustentáveis para a Previdência Social. Tal situação favoreceu a expressão de algumas propostas racionalizadoras no âmbito da burocracia pública que indicavam o fortalecimento do setor governamental, paralelamente à constituição de um movimento político-ideológico em prol de uma reforma de maior envergadura o movimento sanitário. Essas propostas se traduziram em algumas experiências alternativas isoladas na década de 70 e, na década seguinte, em projetos 
institucionais reformistas no âmbito da Previdência Social, que, embora de pequeno impacto, foram precursores do projeto da reforma sanitária e expressaram um movimento político e de idéias em prol da universalização e da publicização da assistência à saúde. Esse projeto foi consagrado formalmente na Constituição de 1988 e implicou mudanças institucionais e dos princípios que norteavam a política de saúde.

Em segundo lugar, é analisado o processo decisório que resultou na reforma da política de saúde durante o processo constituinte. Os contornos desse processo político foram definidos, por um lado, pelo contexto de democratização, que permitiu a expressão e o fortalecimento de novos atores e de uma nova agenda, e, por outro, pelo embate com velhos atores, constituídos na trajetória da política de saúde. Esta teve como um dos seus principais efeitos a estruturação de interesses privados, e nessa medida influenciou o processo decisório e a disputa entre as alternativas de políticas, grosso modo, divididas entre uma proposta publicista e outra privatista. Esses últimos atores demonstraram significativo poder de veto e, apesar de não terem conseguido barrar as alterações institucionais mais significativas, particularmente a criação de um sistema público de acesso universal, garantiram a preservação dos arranjos previamente estabelecidos. O resultado foi que, ao mesmo tempo que a reforma ampliou a responsabilidade estatal no campo da saúde, de forma contraditória alguns dispositivos constitucionais garantiram a continuidade das formas privadas de assistência, independentemente de qualquer intervenção governamental. Como resultado de um acordo político entre os vários pactuantes, a reforma exigiu que todos tivessem que abrir mão das posições iniciais, e se chegou a um resultado político no qual, em alguma medida, todos saíram vitoriosos. As escolhas definidas na Constituição garantiram a convivência da reforma com a continuidade, em um processo de inovação pressionado por interesses e objetivos que tinham sido constituídos em decorrência das políticas anteriores, que limitaram a possibilidade de mudanças descontínuas, mas que, ao mesmo tempo, expressaram o dinamismo institucional ao definir um reordenamento do sistema público de saúde.

Por fim, é analisado o processo de implantação das mudanças jurídicoinstitucionais durante a década de 90, o qual traduziu as ambigüidades da legislação, decorrentes do processo político que the deu origem, caracterizado pelo 
embate entre propostas opostas. É também nessa fase de implementação que se expressaram os outros efeitos de feedback da política de assistência à saúde estabelecida previamente, que, ao configurar um determinado formato institucional, limitou a viabilização concreta dos princípios publicistas e igualitários definidos constitucionalmente, mas negados pela trajetória da política de saúde. Ao propiciar a expansão da assistência privada, vis-à-vis à pública, consolidaram-se organizações e comportamentos vinculados às formas diferenciadas de acesso e de oferta da assistência, emoldurando o processo de formação das preferências dos afetados pela política e expressando-se na ausência de uma identidade coletiva ou de uma demanda universalista. Do ponto de vista político, esses efeitos de feedback se traduziram na ausência de suporte dos segmentos mais mobilizados, que seria necessário por se tratar de uma política de caráter redistributivo que demandaria a constituição de coalizões mais amplas e duradouras.

$\mathrm{Na}$ análise da implantação da reforma, é dada ênfase à questão do financiamento, que tem sido considerado um ponto de estrangulamento para a sua efetivação, pois o subfinanciamento do sistema de saúde não garantiu a implantação dos princípios constitucionais, para permitir tanto a universalização do acesso quanto a ampliação da rede prestadora. Na medida em que a implantação do Sistema Único de Saúde coincide com uma conjuntura de crise e reformas econômicas, os efeitos das políticas de ajuste dos anos 90 não podem ser desconsiderados. Entretanto, a falta de financiamento adequado é interpretada aqui como uma forma de inviabilização sistêmica do sistema público universal, entendendo que a concretização dos princípios constitucionais, em sua completa acepção, não se constituiu como um objetivo consensual do governo. Esse mecanismo indireto de enfraquecimento da reforma é condizente com o ambiente político-econômico geral - caracterizado pela crise de financiamento e por tendências de restrição das atividades estatais - e com as características da coalizão conservadora dos primeiros governos democráticos, afinados com as propostas de restrição dos gastos sociais, na contramão dos princípios constitucionais recém-definidos. Entretanto, o financiamento inadequado é também mais uma manifestação da concepção pública sobre a assistência consolidada na trajetória da política de saúde, caracterizada pela segmentação, a qual a reforma não logrou alterar, e que associa as obrigações 
governamentais à focalização das ações nos mais pobres, em oposição à perspectiva universalista.

Este capítulo traça o processo a partir do qual os efeitos de feedback da política anterior colocaram limites para uma reforma institucional radical que de fato alterasse o modelo anterior, analisando a cadeia de ações movida por interesses diversos, alguns deles já cristalizados nas estruturas institucionais e capazes de conformar as percepções e atitudes dos cidadãos/usuários de serviços de saúde e outros menos institucionalizados, mas que foram capazes de levar a mudanças institucionais profundas, configurando um novo arcabouço jurídico-legal para a assistência médica no Brasil. Apesar disso, não se estendeu ao setor privado a regulamentação e o controle por parte do Poder Público, que se limitou, na Constituição, a tratar de um suposto mas irreal Sistema 'Único' de Saúde. Desta forma, a partir das mudanças constitucionais, passam a conviver as duas estruturas institucionais - um sistema público formalmente universal e inclusivo e um sistema privado em crescimento - aparentemente de forma paralela ou independente, mas que possuem poderosos vasos comunicantes, com interferências recíprocas que se expressam na arena política da saúde.

\section{O Processo de Formação da Reforma da Política de Saúde: o movimento sanitário e os projetos inovadores}

\section{As idéias e os atores}

A formação da proposta de reforma da política de saúde se deu a partir de meados da década de 70, pela articulação de um movimento político-ideológico por uma reforma sanitária, vista como parte integrante de um processo mais amplo de democratização. Esse movimento envolveu a construção teórica de um modelo de compreensão dos determinantes sociais da saúde e um conjunto de ações estratégicas visando à divulgação de idéias, à articulação de pessoas e organizações e à ocupação de espaços institucionais para a experimentação de projetos inovadores como mecanismo de constituição 
de uma alternativa à política vigente. Particularmente na década de 80 , no contexto da 'abertura' do regime autoritário, iriam ocorrer mudanças na política de saúde bastante significativas do ponto de vista de sua concepção, embora bem menos em termos do impacto no modelo de assistência vigente. Como embriões dos princípios da reforma que seria definida no final dos anos 80 durante o processo constituinte, essas experiências eram baseadas em alguns objetivos básicos, como a ampliação de cobertura, a articulação das esferas de governo com vistas à maior utilização da rede pública e a participação da população. Por serem propostas em clara diferenciação com o modelo de assistência prevalecente, essas experiências enfrentaram a oposição dos interesses consolidados na trajetória da política de saúde e da própria burocracia pública afinada com esses interesses.

O processo de redemocratização do país, no âmbito do qual ocorreu essa reforma sanitária, trouxe no seu bojo a preocupação com os aspectos substantivos da democracia que remetem aos direitos sociais, entre eles o direito à saúde. A oposição ao regime militar incluía a luta pela ampliação das políticas sociais com base na crítica ao desempenho do governo autoritário na área social, bem como das políticas econômicas de alta concentração de renda. As propostas políticas dos setores de oposição enfatizavam a redefinição das políticas sociais no sentido da universalização de benefícios mediante um processo redistributivo. Particularmente no campo da saúde, a discussão da 'democratização da saúde' se fazia de forma mais intensa via 'movimento sanitário', que logrou atingir alto grau de organicidade e grande visibilidade política, vindo a ter papel relevante na reformulação da política de saúde.

Ao movimento sanitário é atribuída a liderança política e intelectual da reforma, no interior do qual foi construída uma proposta alternativa para a política de saúde. ${ }^{116}$ De origem acadêmica, esse movimento se articulou com outros segmentos sociais e governamentais, entre os primeiros destacandose a categoria dos médicos e o 'movimento popular em saúde', que, como vários outros, emergiam ou se fortaleciam na conjuntura de transição democrática. No âmbito governamental, teve o apoio de segmentos burocráticos

$\overline{116}$ A análise sobre o movimento sanitário tem como referência principal o trabalho fundamental sobre o tema, realizado por Sarah Escorel (1998): Reviravolta na Saúde: origem e articulag̣a do movimento sanitário. 
que questionavam o modelo assistencial vigente e, nos anos 80 , contou com outro ator, que a partir de então teria um papel proeminente: o Movimento Municipalista em Saúde, constituído pelos secretários e técnicos municipais de saúde. ${ }^{117}$

O marco teórico que foi o referencial ideológico do movimento sanitário e sustentou as suas propostas políticas tem origem na universidade e se expressa na teoria social da saúde. No final dos anos 60 e início dos 70, desenvolveuse uma abordagem marxista histórico-estrutural das condições e dos problemas de saúde da população no âmbito dos departamentos de medicina preventiva (DMPs) de algumas universidades brasileiras. Com a incorporação das ciências sociais ao estudo da saúde, constituiu-se o pensamento médico-social, que, ao levar em conta o caráter político da área da saúde, deslocou o seu objeto do indivíduo para a sociedade, considerada como determinante das condições de saúde, e delimitou um novo campo de estudo, denominado de 'saúde coletiva'. ${ }^{118}$ À crítica da concepção positivista de ciência - universal, empírica, atemporal e isenta de valores - se contrapôs a idéia de uma teoria que informasse e sustentasse a ação política, de modo que a prática sanitarista passou a ser vista como sujeito de transformação. Na perspectiva de seus expoentes, a maioria oriunda de partidos políticos então na clandestinidade, particularmente do Partido Comunista Brasileiro, tratava-se de um movimento contra-hegemônico com propósitos ambiciosos de alterar a correlação de forças a partir da consciência sanitária, tendo como horizonte o socialismo (Rodrigues Neto, 1997; Teixeira, 1987). Dessa forma, o paradigma alternativo de saúde coletiva orientava proposições que implicavam transformações mais profundas não apenas na saúde, mas no Estado, na sociedade e nas instituições em geral (Fleury, 1997). Nessa perspectiva, o movimento sanitário se engajou na luta para a derrubada do governo militar, juntando-se aos demais movimentos sociais que proliferavam no país.

117 De acordo com Gerschman (1995: 41), o autodenominado 'movimento sanitário' era “um grupo restrito de intelectuais, médicos e lideranças políticas do setor saúde, provenientes na sua maioria do Partido Comunista Brasileiro (PCB), que exerceu um papel destacado de oposição ao regime militar, assim como uma trajetória política própria na área da saúde."

118 A adoção do conceito de saúde coletiva, segundo Teixeira (1987: 94), foi "uma originalidade nacional face à heterogeneidade de denominações habituais, como saúde pública, medicina social, medicina preventiva, medicina comunitária”. 
Com o estímulo institucional da Financiadora de Estudos e Projetos (Finep) e da Organização Pan-Americana da Saúde (Opas), desenvolveram-se o conhecimento e a produção teórica em saúde coletiva e a capacitação de profissionais por meio de cursos de mestrado e doutorado, dos DMPs e de programas de residência em medicina social. ${ }^{119}$ A difusão da abordagem médicosocial foi um instrumento importante para a formação de recursos humanos no campo da saúde coletiva, difundindo-se uma nova maneira de pensar e de atuar no setor saúde, transformando o perfil do sanitarista, que passou a incorporar o posicionamento político na sua proposta de atuação em um campo definido como social. Diferentemente da abordagem tradicional de saúde pública, incorporou-se também a análise da política de saúde e da assistência médica previdenciária, sendo elaboradas propostas de transformação tanto do regime político quanto do sistema de saúde. A partir de uma crítica ao saber hegemônico, inicialmente o movimento sanitário se percebia como constituindo um contra-saber que deveria ter efetividade política, sendo ponto de partida para a reforma sanitária (Dâmaso, 1989). ${ }^{120}$

Uma das formas de difusão do pensamento médico-social, associada ao posicionamento pela democratização do país e pela oposição à privatização da saúde, foi por intermédio do movimento estudantil do setor saúde, particularmente nas Semanas de Estudos sobre Saúde Comunitária (Sesacs). Reunindo estudantes, professores e profissionais médicos, representando algumas de suas organizações profissionais, as Sesacs aglutinavam núcleos estudantis de oposição e se realizaram anualmente, no período de 1974 a 1978, nos locais onde havia apoio institucional de universidades ou secretarias de saúde que desenvolviam projetos de medicina comunitária ou de extensão de cobertura por

119 A tese de doutorado de Sérgio Arouca (O Dilema Preventivista), contribuição para a compreensão da medicina preventiva, defendida na Unicamp em 1975, é considerada um dos principais fundamentos teóricos do movimento sanitário. Em 1978, existiam 16 instituições desenvolvendo pesquisas ou elaborando projetos no campo da saúde coletiva, sendo sete instituições acadêmicas, seis prestadoras de serviços de saúde e um centro de pesquisa epidemiológica. Entre 1972 e 1980, foram criados seis cursos de mestrado e doutorado em saúde coletiva, o primeiro deles sendo o mestrado em medicina social no IMS/Uerj, que se constituiu em um centro de pensamento progressista em saúde, os demais na Faculdade de Saúde Pública da USP e nas Faculdades de Medicina de Ribeirão Preto, da USP, Ensp e Ufba (Escorel, 1998).

120 De acordo com Dâmaso (1989: 73): “o conceito de reforma sanitária tem, todavia, um sentido 'forte': trata-se de conceber e fazer da saúde o fundamento revolucionário de uma transformação setorial com ressonâncias estruturais sobre o conjunto social." 
meio da medicina simplificada. ${ }^{121}$ Grande parte desses programas estava vinculada aos DMPs, utilizados na formação de internos e residentes, que atraíam estudantes mais politizados como forma de se vincularem aos problemas da população e de se inserirem nos movimentos populares.

Na perspectiva da produção de conhecimento e veiculação de idéias, e para aglutinação do pensamento crítico em saúde, foram criadas duas entidades importantes no processo de formação dessa comunidade epistêmica voltada para a reforma sanitária: o Centro Brasileiro de Estudos em Saúde (Cebes), em 1976, e a Associação Brasileira de Saúde Coletiva (Abrasco), em 1979. Nos seus primeiros anos, o Cebes teve uma grande produção intelectual, publicando livros e promovendo encontros, reuniões e debates, mas, principalmente, editando a revista Saúde em Debate. Lançada em novembro de 1976, a revista se tornou um veículo de divulgação do pensamento sanitarista, permeado pelas ciências sociais marxistas, e após um ano já possuía cerca de quatro mil assinantes. ${ }^{122} \mathrm{~A}$ Abrasco foi criada para organizar a prática acadêmica em torno da crítica ao modelo de assistência à saúde e para formular propostas, sendo também uma importante entidade para a veiculação de idéias.

No processo de sua articulação e ampliação, o movimento sanitário foi incorporando novos atores. A atuação no âmbito do parlamento foi uma estratégia importante, já que esse era um espaço que possibilitava oportunidade para um debate mais democrático em um contexto autoritário e com fe-

121 Foram realizadas Sesacs em Belo Horizonte, Campinas (SP), Curitiba, Londrina (PR) e Santo André (SP). A medicina comunitária, ou simplificada, era uma proposta alternativa de organização dos serviços de saúde que se difundia na América Latina, voltada principalmente para as populações rurais, por meio de programas baseados no autocuidado, atenção primária realizada por pessoal não-profissional, com tecnologia apropriada e com a participação da comunidade. $\mathrm{O}$ marco político dessas propostas é a Declaração de Alma Ata, firmada na Conferência Internacional sobre Cuidados Primários de Saúde, realizada em 1978, na cidade de Alma Ata, sob os auspícios da Organização Mundial da Saúde. A Declaração estabeleceu como meta a 'saúde para todos no ano 2000', por meio da estratégia da atenção primária, e seus conceitos de extensão de cobertura, participação comunitária e agente de saúde foram difundidos pela Organização Mundial da Saúde (OMS) e pela Organização Pan-Americana da Saúde (Opas). Embora não tenha contado com representação do Brasil, a Conferência "expressa o contexto normativo das principais diretrizes e princípios que passaram a nortear as reformas dos sistemas de saúde a partir dos anos 80 ” (Fundação João Pinheiro, 1999: 31).

122 Como destaca Fleury (1997: 26), em análise retrospectiva: “O Cebes representou a possibilidade de uma estrutura institucional para o triedro que caracterizou o movimento pela reforma sanitária brasileira: a construção de um novo saber que evidenciasse as relações entre saúde e estrutura social; a ampliação da consciência sanitária onde a Revista Saúde em Debate foi, e continua sendo, seu veículo privilegiado; a organização do movimento social, definindo espaços e estratégias de ação política”. 
chamento de outros canais institucionais. A Comissão de Saúde da Câmara dos Deputados tornou-se um local para o debate público sobre a saúde e para a organização do movimento, contando com apoio de parlamentares, inclusive do partido governista, e da sua infra-estrutura (Rodrigues Neto, 1997). Em 1979, o núcleo do Cebes de Brasília teve uma atuação parlamentar importante, assessorando parlamentares da Comissão de Saúde, o que teve como um dos resultados mais expressivos a realização, por iniciativa da Comissão, do I Simpósio sobre Política Nacional de Saúde. Este simpósio foi um marco do movimento pela reforma sanitária, pois contou com grande participação de pessoas de todo o país e marcou a vinculação do movimento sanitário com a discussão concreta da política de saúde. O documento aprovado no simpósio teve o papel simbólico de lançar o projeto do Sistema Único de Saúde ao sugerir os principais componentes da proposta alternativa à política vigente. Entre estes, destacam-se: saúde como direito de todos e dever do Estado; detenção do empresariamento da medicina, considerando os atos médicos como bem social gratuito; unificação do sistema de saúde, cabendo ao Estado a administração do sistema; participação popular na política de saúde; mecanismos eficazes de financiamento; descentralização; e fim dos convênios com pagamento por unidade de serviço.

Outra estratégia foi trabalhar para a eleição de deputados estaduais e federais, prefeitos e vereadores que tinham a saúde em suas plataformas eleitorais e eram ligados à questão mais geral da democratização, o que os aproximava dos objetivos do movimento sanitário, cuja atuação não se restringia à questão sanitária, mas sobretudo estava integrada ao movimento para a derrubada do governo militar.

Ainda na década de 70, integraram-se ao movimento sanitário as ações de dois grupos de profissionais de saúde: os médicos residentes e o Movimento de Renovação Médica. Embora de caráter profissional, no contexto de mobilização contra o regime autoritário esses movimentos assumiram uma postura política e se inseriram nas questões mais gerais da sociedade, particularmente a crítica da política de saúde, reforçando as propostas de transformação. As conseqüências dessa política incidiam diretamente sobre a categoria médica, na forma de progressivo assalariamento, uma vez que os médicos perdiam sua característica liberal, tornando-se assalariados, predominantemente 
no setor público, mas também nas empresas de medicina de grupo. O reflexo dessa nova condição se deu no interior das entidades de classe, ocorrendo o desenvolvimento da ação sindical e da utilização de instrumentos de ação de trabalhadores, particularmente as greves.

No caso dos residentes, o período coincide com uma mudança de postura da Associação Nacional de Médicos Residentes (ANMR), que passou a buscar a regulamentação trabalhista do médico residente, deixando de limitar sua atuação à dimensão educacional da residência médica. Em 1979, os médicos residentes participaram de lutas gerais da sociedade, particularmente a campanha pela anistia, e endossaram algumas propostas do Cebes, como a idéia de que saúde era um dever do Estado.

O 'Movimento de Renovação Médica’ surgiu em 1978 como oposição ao discurso liberal das lideranças médicas tradicionais, assumindo sua condição de categoria assalariada. Suas propostas foram bem recebidas, e em pouco tempo conquistaram as mais importantes entidades da categoria, particularmente a AMB, nas eleições de 1981. O Movimento de Renovação Médica assumiu também a postura de oposição ao regime militar e de denúncia à 'mercantilização da medicina', fazendo oposição ferrenha à medicina de grupo. ${ }^{123}$ De 1978 a 1981, a categoria médica esteve envolvida em movimentos coletivos e se articulou com outros sindicatos de trabalhadores. Nesse último ano, ocorreu uma greve nacional dos médicos, na qual, além das reivindicações por melhores salários e condições de trabalho, eles questionavam a própria política de saúde e reforçavam as propostas de sua transformação no sentido preconizado pelo movimento sanitário.

O Cebes participou do processo de reorganização e renovação das entidades profissionais médicas, assumindo a posição dos profissionais assalariados, criticando os interesses empresariais representados pela Federação Brasileira de Hospitais (FBH) e pela Associação Brasileira de Medicina de Grupo (Abramge).

$\overline{123}$ O que caracterizava o movimento de renovação médica era, segundo Célio de Castro, presidente do Sindicato dos Médicos de Minas Gerais no período de 1980 a 1986, integrante desse movimento, "a defesa intransigente dos direitos dos médicos, mas com o compromisso fundamental de melhorar sempre o atendimento prestado à população. Acho que esse lema sintetiza todos os ideais, não só meus, mas de uma geração" (entrevista para o sindicato, publicada em Sindicato dos Médicos de Minas Gerais, 2000: 31). 
Nos anos 80, a discussão da reformulação da política de saúde ganha a adesão dos movimentos populares em saúde (Mops), que se desenvolviam desde a década anterior mas que só então passam a incorporar as propostas do movimento sanitário, entre elas a crítica à medicina privada financiada pelo setor público. Esses movimentos proliferaram em torno de associações de moradores e outras entidades de bairro em favelas e bairros pobres das periferias das grandes cidades (Gerschman, 1995). ${ }^{124}$ Os Mops se organizaram em torno de reivindicações por melhores condições de vida, saneamento, postos de saúde, água, esgotos, moradia, transportes etc. e tiveram presença marcante de médicos, profissionais e agentes de saúde vinculados à experiência de medicina comunitária, e na sua maioria ligados ao Partido Comunista Brasileiro (PCB), sofrendo também influência da Igreja progressista, por meio das Comunidades Eclesiais de Base. Com base em algumas experiências de medicina comunitária, que previam a participação de agentes de saúde da própria comunidade, começou a se articular o movimento popular em saúde. Na sua primeira fase, de caráter mais reivindicativa, procurava uma atuação independente, de tal forma que a política nacional de saúde não se constituía como um eixo de sua ação. Em uma segunda fase, já no período da 'Nova República', o movimento popular adquiriu maior politização, com a articulação de associações de moradores de diferentes bairros em federações de associações de moradores nacionais e estaduais, o relacionamento com outros movimentos sociais e sindicais, e a atuação no sentido de se desvencilhar das lideranças religiosas e técnicas.

Em síntese, o movimento pela reforma institucional do setor saúde partiu de uma teoria sobre a determinação social da saúde, construiu uma proposta de reforma da política de saúde com base na crítica ao modelo vigente, estabeleceu estratégias para divulgação das idéias e propostas e conseguiu articular um conjunto diversificado de atores em torno delas. Na conjuntura de insatisfação com o regime autoritário e no movimento de constituição de um novo pacto no país, foi possível superar os objetivos e interesses setoriais ou corporativos na afirmação de uma alternativa para o setor saúde, cujo conteúdo

124 Essa análise do movimento popular em saúde é extraída do trabalho de Sílvia Gerschman (1995), A Democracia Inconclusa: um estudo da reforma sanitária brasileira. 
principal era a universalização e a responsabilidade pública, em oposição clara ao modelo segmentado e híbrido que caracterizava a política de saúde. Como define Vaitsman (1989: 153), o movimento sanitário:

É um movimento que reúne intelectuais, profissionais da área de saúde, organizações e associações, tendo como referencial ético a saúde como valor universal, o que só pode ser concretizado através da reformulação do sistema, para atingir a universalização e equidade. Para tanto, o movimento apresenta um conjunto de propostas políticas e técnicas que se consubstanciam enquanto uma 'Reforma Sanitária' (...).

O Movimento Sanitário não é um grupo de interesses e nem é formado por grupos de interesses. Embora dele possam fazer parte grupos de produtores (médicos, por exemplo) e de consumidores (usuários, potenciais ou reais, dos serviços de saúde), organizações de representação de interesses e partidos políticos, o que o caracteriza enquanto movimento é o fato de ele aglutinar além de indivíduos, entidades de diferentes naturezas funcionais, organizacionais e políticas, com uma proposta ético-política visando interesses coletivos.

Com essas características, o movimento terá um papel fundamental no processo de democratização e de formulação de uma imagem-objetivo para a política de saúde do Brasil, mas perderá seu vigor após a retomada da democracia e no momento de implementação da política de saúde, quando os diferentes interesses e clivagens ideológicas internas vão se explicitar e quando se dará o embate com as propostas contrárias em razão dos interesses constituídos ao longo do desenvolvimento da política de saúde.

\section{Crise e projetos institucionais inovadores da década de 70}

No âmbito da política de saúde, o contexto em que se articulou o movimento sanitário caracterizava-se pela preponderância da Previdência Social e pela ênfase na assistência médica curativa, montada sobre uma rede de prestação de serviços predominantemente privada. Paralelamente, expandia-se a assistência privada, incentivada por decisões governamentais. Contra esse modelo vai se orientar o movimento sanitário com base na crítica ao crescimento do setor privado com o financiamento do setor público. No interior da Previdência já existiam correntes de pensamento não afinadas com os interesses empresariais e com o grupo técnico-burocrata de tendência privatista que co- 
mandava a instituição, identificada como o espaço onde se consolidou uma aliança entre os interesses privados e a burocracia estatal. Esse pensamento divergente defendia o fortalecimento do setor público e, embora numericamente reduzido, encontrou na crise financeira da Previdência uma conjuntura favorável para a crítica ao modelo hegemônico, de tal forma que a crise contribuiu para uma modificação na arena política. ${ }^{125}$

A prioridade dada aos projetos sociais como mecanismo de legitimação do governo Geisel (1974-79) abriu espaços institucionais no Ministério da Saúde para técnicos com pensamento diferente do predominante. Nesse período, desenvolveram-se projetos orientados por propostas transformadoras para o sistema de saúde que expressavam a crítica ao modelo de prestação da assistência, mostravam modelos alternativos e indicavam a penetração de um projeto ideológico de reforma sanitária. Em alguns aspectos, eles se afinavam com as propostas de racionalização e modernização administrativa típicas do período, as quais, no caso do setor saúde, sofriam grande influência da Opas. Nesse contexto, inserem-se as propostas de extensão de cobertura e de participação comunitária, buscando-se coordenar recursos, reduzir custos e realizar uma alocação tecnicamente planejada dos recursos (Cordeiro, 1979). ${ }^{126}$ Apesar de não terem afetado substancialmente o modelo prevalecente, esses projetos motivaram a reação dos setores favorecidos na trajetória da política de saúde, contribuindo para a explicitação das divergências ideológicas e de interesses.

O primeiro desses projetos foi o Plano de Localização de Unidades de Serviços (Plus), criado em 1975 mas derrotado em razão do enfrentamento com os interesses dos prestadores privados, apoiados nos consistentes anéis burocráticos da Previdência Social. Apoiando-se nas diretrizes de modernização administrativa e de expansão física por meio do planejamento racionalizador,

\footnotetext{
125 Conforme foi visto no capítulo 2, a crise se expressou de forma aguda em meados da década de 70 e tinha como um de seus determinantes a dificuldade de financiamento da expansão de cobertura da assistência médica previdenciária por meio da contratação de serviços privados, de alto custo e indutor de corrupção em razão do mecanismo de pagamento predominante.

126 Como afirma Rodrigues Neto (1997: 66), ao mesmo tempo que assessoravam o governo, os integrantes do movimento sanitário assessoravam parlamentares para questionar as ações e políticas do próprio Ministério da Saúde, como uma "tática sui generis" de investir nas contradições, além "de propiciar o acesso de informações privilegiadas, que eram repassadas tanto ao movimento, como para jornalistas e, especialmente, aos parlamentares a ele vinculados, para pronunciamentos, argüições e denúncias".
} 
o plano experimentou uma metodologia de programação de serviços com base em necessidades normatizadas da população confrontadas com a oferta de serviços, e que indicava a universalização num momento em que os serviços de saúde estavam restritos institucionalmente aos segurados da Previdência e propunha medidas que privilegiavam a rede pública. A reação dos prestadores privados se dirigia contra o que denominavam de pensamento 'estatizante' e teve força suficiente para barrar o Plus (Escorel, 1998).

No mesmo ano, desenvolveu-se o Projeto Montes Claros (PMC) como uma aplicação regional de certas diretrizes de um modelo alternativo de organização dos serviços de saúde e no qual foram experimentados princípios defendidos pelo movimento sanitário que seriam consagrados nas mudanças constitucionais posteriormente, como: universalização, regionalização, hierarquização, administração democrática, integralidade da assistência e participação comunitária. O PMC também enfrentou oposição de forças conservadoras dentro do Ministério da Saúde, mas principalmente dos interesses privados vinculados à burocracia que dominava a política previdenciária, uma vez que a participação da Previdência Social no financiamento era imprescindível para a manutenção do programa. Essa oposição foi capaz de inviabilizar o projeto, mas o PMC obteve apoio de outros grupos do movimento sanitário, como os sindicatos médicos, os movimentos dos profissionais de saúde, o Cebes, o movimento estudantil e a universidade. Sem ter alcançado seus objetivos, o PMC, entretanto, foi expandido para outras partes do país, por meio do Programa de Interiorização de Ações de Saúde e Saneamento (Piass), que adotaria uma estratégia semelhante.

Criado em 1976, o Piass seguiu um modelo de medicina comunitária e de extensão de cobertura com o oferecimento de serviços básicos, conforme preconizado por organismos internacionais e tendo como referência experiências municipais de projetos alternativos. Priorizava a região Nordeste, particularmente vilas e povoados rurais. Isso se justificava pela carência da região, mas também por razões político-estratégicas, uma vez que eram "áreas e populações fora dos interesses privados do setor saúde” (Rosas, 1981: 99, apud Escorel, 1998: 159), concentrados nas regiões Sul e Sudeste. Embora o comando gerencial coubesse aos sistemas regionais de saúde, a Previdência Social participou pela primeira vez de forma financeira e programática em um programa de saúde 
pública - que institucionalmente cabia ao Ministério da Saúde - por meio de ações que contrariavam o pensamento privatizante hegemônico. O Piass significou o fortalecimento do setor público, particularmente do Ministério da Saúde, coordenador do programa, e das secretarias estaduais, uma vez que as ações se faziam em cooperação entre as duas instâncias governamentais. Foi nesse espaço institucional que se desenvolveu entre técnicos e profissionais uma crítica mais forte à política de assistência à saúde conduzida pelo Inamps e suas diretrizes orientaram as propostas do movimento sanitário. O Piass teve outro efeito político relevante ao propiciar o aparecimento de uma frente política dos secretários de saúde envolvidos no programa, com o objetivo principal de reivindicar recursos da Previdência Social. Em 1980, esses últimos organizaram o Conselho Nacional de Secretários de Saúde (Conass), que veio a se constituir como mais um ator que se juntaria ao movimento reformista da saúde, identificado com o fortalecimento do setor público.

\section{Aprofundamento da crise e iniciativas reformistas na década de 80}

Se na década de 70 configurou-se um discurso alternativo no âmbito da sociedade e ensaiaram-se algumas práticas governamentais alternativas, na década seguinte, durante o último governo militar, desenvolveram-se propostas mais globais de reformulação da assistência médica em um contexto identificado pelo aprofundamento da crise da Previdência Social. Entre as causas relacionadas para a crise financeira estão a contradição estrutural de um sistema em expansão com crescente absorção de faixas da população coberta em direção a um modelo de cidadania universal, sem alterações no regime financeiro baseado no modelo de relação contratual; a queda dos salários reais e a redução do crescimento do emprego, em razão de recessão econômica, desacelerando a receita de contribuições para a Previdência; o aumento das sonegações e a diminuição das transferências da União; os problemas na arrecadação e gestão dos recursos; o alto custo dos serviços de assistência médica; a corrupção facilitada pelos mecanismos de financiamento; e as dificuldades de controle do setor privado prestador de serviços.

No debate sobre a crise, ficava bem configurada a arena política da assistência médica e delineavam-se várias propostas, polarizadas entre a priorização 
do setor público, de acordo com as idéias do movimento sanitário, e a privatização da assistência, expressando os interesses constituídos no setor saúde. As companhias de seguro, em proposta apresentada pelo Instituto de Resseguros do Brasil, sugeriam a eliminação da assistência médica do plano de benefícios e serviços da Previdência Social, impondo-se o seguro-saúde privado compulsório. Por sua vez, a Abramge, tirando proveito das críticas à assistência médica previdenciária que convergiam para o setor prestador de serviços contratado pela Previdência Social e representado pela FBH, defendia a medicina de grupo como a alternativa mais racional e econômica, propondo a extensão dos convênios com empresas. Um dos espaços em que se expressavam esses interesses em disputa foram as audiências públicas na Comissão de Saúde da Câmara dos Deputados, que se tornaram palco de intensos debates.

Nesse momento, o movimento sanitário já estava organizado e reconhecido como interlocutor na arena de saúde e, após ampla mobilização, conseguiu ocupar espaços institucionais importantes, com o objetivo de tentar mudar a direção da política pública, além de estabelecer contatos com outros movimentos pela democratização do país. ${ }^{127} \mathrm{O}$ contexto de crise da assistência médica previdenciária favoreceu as propostas de mudança, que tinham também um sentido racionalizador, de tal forma que o projeto do movimento sanitário iria se configurar como uma solução para a crise.

Com o objetivo principal de conter custos, em uma perspectiva racionalizadora, desenvolveram-se propostas de reformulação no interior da Previdência Social que tinham as seguintes características: privilegiação do setor público prestador de serviços; integração institucional por meio de instâncias colegiadas de gestão e programação conjunta; desconcentração das ações de saúde para os níveis estadual e municipal; e participação de entidades representativas da sociedade civil na formulação das políticas de saúde.

O primeiro projeto da década foi o Programa Nacional de Serviços Básicos de Saúde (Prev-Saúde), proposto por técnicos do setor público, em

\footnotetext{
127 Particularmente no período que antecede a transição do regime militar para a 'nova república', vários integrantes do movimento sanitário ocuparam postos-chave na administração do setor saúde. Essa estratégia gerou críticas internas, sendo considerada por alguns de seus componentes como o abandono das propostas transformadoras que caracterizaram o início do movimento em favor de reformas meramente administrativas. Esse foi um dos pontos de conflito que fraturaram internamente o movimento, dividido entre tendências mais ou menos radicais. Sobre essa questão ver, entre outros, Teixeira (1987) e Cohn (1989).
} 
1980, como proposta de reformulação ampla da política de saúde. O PrevSaúde buscava traduzir as experiências institucionais anteriores e incorporava as propostas da Organização Mundial da Saúde e do movimento sanitário. O projeto estabelecia condições para a inclusão dos serviços privados no sistema público, limitando-os aos serviços sem fins lucrativos, de forma que gerou intensa reação. Mesmo sendo reformulado, nunca foi implantado. O debate travado sobre o Prev-Saúde, embora estabelecido em torno do discurso, pois não foi tomada nenhuma medida concreta, iluminou o posicionamento dos diferentes grupos e explicitou a luta ideológica acerca de grandes modelos de orientação da assistência médica. Para seus críticos, o Prev-Saúde era visto como a estatização do setor; para seus proponentes no âmbito das instituições previdenciárias, apenas como uma medida racionalizadora. Na primeira vertente, explicitando os famosos anéis burocráticos dentro da Previdência Social, juntavam-se na oposição ao Prev-Saúde tanto o presidente do Inamps ${ }^{128}$ quanto a FBH e a Abramge, embora essas duas entidades empresariais tivessem perspectivas diversas, em razão dos seus diferentes interesses: para a FBH, a proposta era estatizante ao marginalizar a rede hospitalar privada com a pretensão de substituí-la pelos serviços públicos (na sua visão, mais dispendiosos); ao incluir apenas os hospitais filantrópicos e beneficentes; ao retirar incentivos a empreendimentos de cunho lucrativo, negando financiamento à iniciativa privada por meio do FAS; e por estabelecer maior controle ou eliminação de recursos para contratação de serviços privados. Para a Abramge, o projeto seria estatizante ao propor uma participação muito débil da iniciativa privada, representada apenas pelos hospitais privados e não mencionando as diferentes formas de medicina organizada, entre as quais a medicina de grupo.

No ano seguinte, outra proposta de reforma logrou maior consenso, e foi criado, no âmbito do MPAS, o Conselho Consultivo da Administração de Saúde Previdenciária, o Conasp (decreto 86.329, de 2/9/81), como uma instância reguladora, composto por notáveis da medicina, representantes de ministérios, dos trabalhadores do setor patronal e dos prestadores privados de serviços. O objetivo básico pretendido com a criação do Conasp era

\footnotetext{
128 Esse declarou considerar o projeto nitidamente estatizante, ao propor, no seu entendimento, o esvaziamento da empresa privada.
} 
racionalizar a prestação da assistência médica e seus custos crescentes, disciplinando o atendimento médico-hospitalar entre hospitais conveniados com base em uma posição crítica sobre as implicações decorrentes das formas de financiamento do setor privado. Embora não previsse participação exclusiva do setor público, no 'Plano Conasp’ foi dada preferência à reativação dos serviços públicos, ${ }^{129}$ segundo uma proposta de reversão gradual do modelo privatista. Medidas racionalizadoras estabeleceram um novo sistema de contas hospitalares, substituindo o criticado sistema de pagamento por unidades de serviço pelo cálculo do custo global do procedimento médico e, ainda, impondo uma racionalização na assistência ambulatorial, à qual se propunha dar prioridade. O plano de contas hospitalares resultou em diminuição das internações e enfrentou grande oposição da FBH, embora tivesse apoio do movimento sanitário, da medicina liberal e da Abramge, revelando o fracionamento dos interesses privados (Mendes, 1993).

O plano propunha ainda uma redefinição político-institucional, pretendendo criar uma rede única de serviços de saúde pelo estabelecimento de convênios trilaterais entre o Ministério da Saúde, o Ministério da Previdência e Assistência Social (MPAS) e os governos dos estados, por intermédio de suas secretarias de Saúde, como forma de racionalização dos recursos públicos, passando a privilegiar o financiamento do setor público. A concretização desses convênios viria com as Ações Integradas de Saúde (AIS), como uma estratégia para unificação do sistema de saúde mediante a integração entre as instituições públicas de saúde federais, estaduais e municipais no âmbito de cada unidade federada. As AIS são antecedentes importantes da reordenação do sistema de saúde após a Constituição de 1988, no sentido preconizado pelo movimento sanitário. ${ }^{130}$

\footnotetext{
129 Foram então tomadas medidas concretas para reativar três hospitais públicos, além de conceder maior dotação de recursos para o setor próprio da Previdência Social.

130 "A partir de maio de 1984, a estratégia das AIS, tendo como referência as diretrizes contidas no plano do CONASP, passou a ser implementada com base nos seguintes princípios gerais: responsabilidade do poder público; integração interinstitucional, tendo como eixo o setor público; definição de propostas a partir do perfil epidemiológico; regionalização e hierarquização de todos os serviços públicos e privados; valorização das atividades básicas e garantia de referência; utilização prioritária e plena da capacidade potencial da rede pública; descentralização do processo de planejamento e administração; planejamento da cobertura assistencial; desenvolvimento dos recursos humanos e o reconhecimento da legitimidade da participação dos vários segmentos sociais em todo o processo" (Escorel, 1998: 185).
} 
Essa proposta sofreu grande oposição mesmo na direção geral do Inamps por dirigentes favoráveis à manutenção da política de compra de serviços privados, além de, mais uma vez, ter mobilizado diferentes grupos de interesse defensores do status quo. Os convênios foram implementados inicialmente apenas em alguns estados e municípios, atingindo no final da década cerca de 2.500 municípios. ${ }^{131}$

Em razão das alterações observadas na política de assistência à saúde durante os anos 80, alguns resultados, mesmo que bastante tímidos, foram observados. Como conseqüência das medidas do Plano Conasp, de fato ocorreu um aumento relativo da produção de serviços ambulatoriais em detrimento das internações hospitalares, que predominaram na política 'hospitalocêntrica' dos anos 70, de tal modo que o número de internações no período 1982/87 caiu de 13,1 milhões para 11,7 milhões (Médici, 1990). Observou-se também uma participação declinante da rede privada contratada nas internações realizadas pela Previdência Social, que, de mais de $90 \%$ das internações, chegando a atingir cerca de $97 \%$ do total, reduziu-se para $80,3 \%$ em 1987 , sem que se conseguisse, contudo, eliminar a forte predominância do setor privado nas internações hospitalares.

Durante toda a década declinaram os gastos da Previdência com a rede privada de saúde, passando de 71,3 \% do total em 1981 para 45,9\% em 1987, incluindo-se nessa cifra tanto os pagamentos feitos aos prestadores de serviço, lucrativos ou filantrópicos, quanto os repasses para as entidades conveniadas empresas ou sindicatos (Médici, 1990). No mesmo período, verificou-se uma ampliação significativa dos gastos com os prestadores de caráter filantrópico, que cresceram cerca de $76 \%$ no período de 1981 a 1987, atingindo quase $10 \%$ das despesas com os prestadores privados, resultado que expressa a política de priorização dos prestadores filantrópicos. Mas, dada a sua pouca relevância no conjunto das despesas previdenciárias com assistência à saúde, permaneceu ainda no final do período a predominância dos gastos com os prestadores

\footnotetext{
131 De acordo com Hésio Cordeiro, então presidente do Inamps, em depoimento em audiência pública na Subcomissão de Saúde, Seguridade e Meio Ambiente durante o processo constituinte (DANC, 17/7/87), em 1984, apenas 112 municípios participavam do programa, passando para 840 no final de 1985 (ou 950, de acordo com Mendes, 1993). A partir de então, as AIS foram impulsionadas, atingindo, em 1987, 2.500 municípios e 70\% da população (DANC, 17/7/87).
} 
lucrativos, que consumiram sozinhos cerca de 40,5\% do total de despesas do Inamps em 1987. Porém, em termos relativos, houve uma forte queda das despesas com esses prestadores, uma vez que elas permaneceram praticamente inalteradas e, até, em declínio, enquanto as despesas totais do Inamps cresceram significativamente em mais de 50\% entre 1981 e 1987.

Significativo acréscimo ocorre com as transferências feitas pelo Inamps a outros órgãos públicos, expressando a política de ampliação dos convênios com estados e municípios, particularmente por meio das AIS e do Suds outra inovação institucional a partir de 1987. Esse gasto com transferências das despesas com assistência médica do Inamps salta de 5,7\% em 1981 para 30,4\% em 1987. Em contrapartida, as despesas relativas aos convênios com sindicatos e empresas vão perdendo importância, atingindo menos que 1\% dos gastos em 1987, indicando seu desligamento do financiamento do setor público. Embora as normas que regulamentavam os convênios com empresas não tivessem sido revogadas, o Inamps deixou de fazer novos convênios na década de 80 e não renovou os antigos contratos. Ao mesmo tempo, reduziu-se o interesse das empresas pelos convênios em razão do valor pago pelo Inamps, que deixou de ser reajustado, tornando-se irrelevante, sem falar em outras restrições. ${ }^{132}$ Expressão da queda de importância dos convêniosempresa foi a diminuição dos recursos gastos com esses convênios, que caíram 86,6\% entre 1981 e 1987, passando de US\$113,5 milhões para US\$15,2 milhões (Médici, 1990).

Ao mesmo tempo, o setor privado passou a buscar mercados alternativos, sendo o período caracterizado pela expansão do segmento privado de saúde, independente do financiamento público direto. Essa tendência passou a ser justificada em razão dos mecanismos considerados insatisfatórios de reajuste dos valores pagos aos prestadores privados em momento de acentuada inflação. Como expressão dessa insatisfação, ocorreu uma redução da proporção de estabelecimentos privados lucrativos conveniados com o Inamps de $64,6 \%$ para $52,8 \%$ entre 1980 e 1984.

\footnotetext{
132 De acordo com Alexandre Lourenço, da Abramge, em depoimento em audiência pública durante o processo constituinte, em 1987 o valor pago pelo Inamps era de $\mathrm{R} \$$ 0,53 por funcionário assegurado, o que representava menos do que $1 \%$ do custo da assistência médica prestada pela empresa (DANC, 18/7/87).
} 
Enfim, os projetos dos anos 70 e as reformas dos anos 80 constituem experiências de organizações alternativas dos serviços de saúde, em que se experimentam algumas propostas, como descentralização da gestão; integração das ações preventivas e curativas; expansão de cobertura de uma perspectiva universalizante, ou seja, desvinculada da condição de segurado da Previdência; participação comunitária; ênfase na atenção primária; articulação das ações de diferentes instâncias públicas; e fortalecimento do setor público. Mesmo que de alcance reduzido e sem significar uma alteração do modelo de assistência prevalecente, essas experiências e reformas mostraram um novo desenvolvimento institucional dos serviços de saúde, evidenciando a existência de uma articulação de atores em torno dessa mudança. Além disso, explicitaram o conflito entre diferentes concepções da assistência à saúde, que, grosso modo, podem ser chamadas de publicista e privatista. A concepção publicista, por sua vez, tinha variantes internas, sendo, por um lado, assumida por parte da burocracia pública que via o fortalecimento do setor público de uma perspectiva apenas racionalizadora e, por outro, constituindo-se como uma visão com objetivos ideológicos e políticos mais amplos no sentido da 'democratização da saúde' e de transformações mais globais, e se manifestava entre os técnicos integrantes do movimento sanitário.

Nesse momento, a democratização da saúde se confundia com a sua publicização, na medida em que se contrapunha ao modelo privatista da assistência médica que significava o status quo. Este era defendido pelos portadores da concepção ou ideologia privatista, característica dos principais dirigentes da instituição previdenciária que, por meio dos anéis burocráticos, defendiam os interesses empresariais do setor saúde. Tal embate intraburocrático é bastante claro no período e se estende dos anos 70 até a Constituinte. Apesar do fortalecimento das propostas publicistas, a trajetória da assistência nesse período é marcada pela expansão da assistência médica privada, que, conforme foi visto, na década de 80 amplia sua cobertura e seu âmbito de ação, favorecida por vários dispositivos governamentais e pela própria crise da assistência pública. $\mathrm{O}$ embate envolvendo as propostas alternativas exemplifica as conseqüências das políticas anteriores sobre o processo político, que não só atribuíram poder aos prestadores privados, mas definiram suas preferências durante a trajetória da política que os fez, em parte, dependentes do setor público para sua expansão. 


\section{O Processo Decisório da Reforma da Política de Saúde: marchas e contramarchas na mudança institucional durante a Constituinte}

Após a derrocada do regime autoritário, com a ascensão do primeiro presidente da República civil após vinte anos de governos militares, num momento de constituição de um novo pacto social do país, cresceram as articulações em torno da redefinição da política de saúde, que, entre todas as políticas sociais, contava com uma proposta política e substantivamente bem mais articulada. O processo decisório da reforma foi precedido pela criação ou convocação de vários fóruns coletivos, nos quais se foi concretizando, de maneira formal e política, a proposta de transformação da política de saúde. O primeiro deles foi a VIII Conferência Nacional de Saúde, convocada em 1986 pelo governo federal com o objetivo explícito de obter subsídios para a reformulação do Sistema Nacional de Saúde. Diferentemente das conferências anteriores, ${ }^{133}$ também os usuários dos serviços de saúde foram convocados a participar. No clima de mobilização do período, a conferência contou com a participação de cerca de cinco mil pessoas, representantes de diferentes segmentos sociais, embora com a ausência dos prestadores privados, sendo considerada um marco na trajetória da reforma sanitária brasileira e do êxito do movimento sanitário em conformar a agenda da saúde. Em primeiro lugar, porque a ampla participação e a representatividade mostraram a visibilidade que a questão da reforma sanitária tinha atingido e a articulação política em torno dela; em segundo, porque o seu relatório final consolidava as propostas do movimento sanitário e formalizava o projeto da reforma. ${ }^{134}$ Esse relatório foi a base para as discussões que se travaram na Constituinte e cujo resultado final foi a incorporação constitucional de alguns dos princípios básicos defen-

\footnotetext{
133 As conferências foram instituídas em 1937 como instância decisória da política de saúde, tendo a primeira acontecido apenas cinco anos depois e as demais em intervalos irregulares, apesar da previsão de que fossem bienais.

134 Rodrigues Neto (1997: 69-70) chama a atenção para o fato de que as conclusões da VIII Conferência "não conseguiram consenso no interior do movimento social na área da saúde, por duas vias extremas: uma, pela não inclusão das teses do setor privado de prestação de serviços de saúde que mesmo convidado, negou-se a participar da conferência; outra pela derrota, pelo voto da tese/ tática da 'estatização imediata', defendida pelos setores sindicais ligados à CUT e pelo PT e PDT, principalmente".
} 
didos e difundidos pelo movimento sanitário, sintetizados na definição de que saúde é um direito de todos e um dever do Estado.

Um segundo fórum foi a Comissão Nacional de Reforma Sanitária, constituída após a conferência, por decisão interministerial dos ministérios da Previdência, da Saúde e da Educação e composta de forma paritária por governo e sociedade civil, a quem coube a elaboração de uma proposta para a Constituinte na esfera de governo. ${ }^{135}$ Agregando representantes do governo, dos trabalhadores e da iniciativa privada, essa comissão, apesar das divergências, conseguiu produzir uma proposta comum, formalizando as condições mínimas para a reforma sanitária, considerada um verdadeiro "pacto social na área da saúde" (Possas apud DANC, 17/7/87: 192).

A contrapartida da comissão governamental no âmbito da sociedade foi a Plenária Nacional de Entidades de Saúde, criada com o fim de dar continuidade à articulação dos organismos da sociedade civil e de elaborar um Projeto Constitucional (Gerschman, 1995). ${ }^{136}$ Tanto na Comissão quanto na Plenária, o movimento sanitário original se incorporou a um leque maior de entidades, constituindo-se numa frente de diferentes forças políticas em torno de um projeto. Com uma composição ampla, os conflitos ideológicos não tardaram a se evidenciar, substituindo o consenso maior verificado no período autoritário. A maior polarização no âmbito da Comissão da Reforma Sanitária se deu em razão da participação de representantes da iniciativa privada. Mas, além dessa polarização, evidenciaram-se os conflitos intra-segmentos no âmbito dos apoiadores da reforma. O Mops, durante o processo constituinte, vai sofrer

135 A comissão era composta por 26 membros, representantes de ministérios (Saúde, Previdência e Assistência Social, incluindo aí Inamps, Educação e Cultura, Trabalho, Desenvolvimento Urbano, Ciência e Tecnologia); da Secretaria de Planejamento da Presidência da República; representantes das secretarias de saúde estaduais (incluindo o presidente do Conass) e municipais; representantes do Senado e da Câmara dos Deputados; das centrais sindicais (Contag, CGT, CUT); das centrais patronais (CNI, CNC, CNA); por prestadores privados de serviços de saúde (Confederação das Misericórdias, Federação Brasileira de Hospitais); profissionais de saúde (Federação Nacional dos Médicos, Associação Brasileira de Enfermagem); e representante da Associação de Moradores e Conselho Nacional das Associações de Moradores.

136 “A Plenária Nacional de Entidades de Saúde estava constituída por entidades representativas do movimento popular (Mops e Conam), do movimento sindical (CUT, CGT e Contag), dos profissionais de saúde (Federações, Confederações, Associações Nacionais, Sindicatos e Conselhos de uma vasta gama de trabalhadores da saúde), dos partidos políticos (PCB, PC do B, PT e PSB) e de representantes da Academia (ABRASCO, Departamento Nacional de Estudantes de Saúde da UNE, entidades científicas), além de entidades representativas setoriais como o Cebes, o Conass e o Conasems" (Escorel, 1998: 190). 
grande cisão entre facções com perspectivas ideológicas distintas, e algumas delas se negavam a participar na construção de uma proposta governamental. ${ }^{137} \mathrm{O}$ próprio movimento sanitário como um todo vai apresentar fissuras no seu interior no embate entre reformismo e transformação, na medida em que o projeto socialista de ampla reforma do Estado que deu origem ao movimento foi sendo substituído por uma proposta de mudança na forma de intervenção estatal no setor saúde, com a alteração da política de saúde em direção da universalização do acesso e da descentralização. No decorrer do processo político, foram se ampliando as alianças, o que teve como uma conseqüência a redefinição do projeto inicial em torno de princípios sobre os quais foi possível obter um consenso maior (Gallo \& Nascimento, 1989). No processo de constituição de uma proposta que pudesse ter efetividade política, as idéias do movimento sanitário foram reconfiguradas de forma a acomodar os interesses e as práticas consolidados. Nesse processo, várias idéias do movimento visando a uma maior alteração do Estado não conseguiram influenciar a política.

Paralelamente à discussão da reforma nos fóruns políticos, no âmbito governamental foi dado um passo no processo de mudança institucional, no sentido da unificação e descentralização do sistema de saúde, com a criação dos Sistemas Unificados e Descentralizados de Saúde (Suds). Propunha-se, por meio do Suds, a transferência dos serviços de saúde do Inamps, órgão federal vinculado ao MPAS, para os estados e municípios, juntamente com os instrumentos de controle sobre o setor privado, agilizando o processo de descentralização - um dos princípios básicos da reforma em discussão. Buscava-se também fortalecer o setor público, desestabilizar o Inamps, com a ruptura dos anéis burocráticos previdenciários, enfraquecer o segmento privado contratado e reforçar o segmento privado filantrópico (Mendes, 1993). O Suds foi aprovado em julho de 1987, quando a presidência do Inamps era

\footnotetext{
37 "Uma facção é mais crítica e radical na sua visão do estado, referindo-se a ele como um espaço exclusivo das classes dominantes. Tem um discurso anti-estado [sic], rejeita qualquer ação estatal e considera que se houver medidas que favoreçam as classes mais pobres, elas terão por objetivo o controle social. Assume, conseqüentemente, uma postura mais 'autonomista' e de distanciamento da máquina estatal. A outra facção, ainda que caracterize o Estado como domínio da burguesia, não acredita que seja tão monolítico a ponto de não haver no seu interior fraturas através das quais seja possível pressionar e negociar para a obtenção de conquistas sociais em saúde" (Gerschman, 1995: 54). A luta ideológica interna levou a um esvaziamento e à desarticulação do movimento popular em saúde no final da década de 80, cujo último encontro de caráter nacional ocorreu em 1987.
} 
ocupada por um membro histórico do movimento sanitário. Mas sua implantação gerou grandes resistências de várias frentes, tanto na burocracia pública quanto no setor privado, especialmente da FBH e, até, entre as elites políticas regionais. Desta forma, só teve resultados efetivos nos estados onde havia envolvimento dos dirigentes locais com a mudança. Expressão da fragilidade das propostas inovadoras no interior da burocracia governamental, mesmo quando formalmente se davam passos importantes no sentido de definir uma ampla reforma da política de saúde, é o fato de que menos de um ano depois de ter criado o Suds o presidente do Inamps foi demitido, juntamente com outros quadros do movimento sanitário que ocupavam posições relevantes na burocracia setorial.

As resistências ao Suds mostram as dificuldades de implantação efetiva de mudanças em um contexto político-institucional caracterizado pela constituição de fortes atores e interesses públicos e privados que ofereciam resistência a elas, como políticos, burocracia do Inamps e do Ministério da Saúde e o setor privado. Em reação às mudanças, esses atores que defendiam o status quo se rearticularam no momento em que, simultaneamente, aprovava-se o capítulo da saúde na Constituição, que institucionalizava as mudanças no sentido de universalização da atenção à saúde, unificação das instituições públicas, priorização do setor público e descentralização.

Com a convocação da Assembléia Nacional Constituinte, a atuação desses grupos e do movimento sanitário passou a privilegiar o processo parlamentar, num momento em que o Congresso se tornava mais permeável à influência da sociedade e se constituía como o locus decisório fundamental. ${ }^{138}$ Isso se fez inicialmente na Subcomissão de Saúde, Seguridade e Meio Ambiente, primeira etapa do processo de elaboração constitucional de acordo com o regimento aprovado. ${ }^{139} \mathrm{~A}$ composição dessa comissão expressava as grandes

\footnotetext{
138 Para Rodrigues Neto (1997), formaram-se durante o processo constituinte vários lobbies, entre os quais o do movimento sanitário, diferente apenas por sua afinidade com os interesses sanitários e populares, mas sem deixar de ser um lobby.

139 Segundo o Regimento inicial da Constituinte, o processo constitucional tinha o seguinte trâmite: 1) subcomissões, em que em audiências públicas se debatiam com entidades da sociedade civil, lideranças e dirigentes institucionais as reivindicações e propostas e se elaborava um relatório apresentado como anteprojeto para a fase seguinte; 2) comissões temáticas, encarregadas de elaborar o anteprojeto com base nos relatórios apresentados pelas subcomissões; 3) comissão de sistematização, encarregada de elaborar o projeto de Constituição para ser discutido, emendado e votado pelo plenário; e 4) plenário da constituinte.
} 
clivagens de interesses, polarizados entre os adeptos das propostas do movimento sanitário, que defendiam a ampliação da rede pública e a participação secundária e transitória de instituições privadas, com prioridade para as instituições filantrópicas, e os defensores da iniciativa privada, da livre escolha, do pluralismo do atendimento e da liberdade de atuação do setor privado. Claramente no processo constituinte se explicitaram as duas visões antagônicas sobre a assistência à saúde, definidas como estatizante e privatizante. Se a primeira representava a perspectiva inovadora dos atores que se articulavam em torno da reforma do sistema de saúde, a segunda representava os interesses e concepções forjados na trajetória da política de saúde como efeito de feedback do sistema de saúde vigente há mais de duas décadas.

As audiências públicas realizadas no âmbito da subcomissão expressaram as mesmas clivagens e constituíram-se como a arena em que se explicitaram e se articularam os diferentes atores com interesses na saúde. Fato notório era que apenas os defensores das idéias do movimento sanitário tinham propostas mais elaboradas, fruto de um longo processo de desenvolvimento teórico e de articulação política, de tal forma que, em linhas gerais, as principais propostas definidas na VIII Conferência Nacional de Saúde como símbolo do movimento sanitário seriam reforçadas por diferentes categorias, como a CUT, sindicatos de profissionais de saúde e Conselho Federal de Medicina, além de grande parte dos constituintes integrantes da subcomissão. O movimento pôde utilizar seus conhecimentos como recurso de poder no processo de tomada de decisões, os quais naquele momento do processo constituinte puderam ser utilizados para definir alternativas. Entretanto, a possibilidade de alteração brusca do sistema de saúde com base nessa proposta suscitou a mobilização e evidenciou o peso e a capacidade de articulação tanto dos representantes das instituições privadas (medicina de grupo, cooperativas médicas e seguradoras) como dos prestadores de serviços privados, unidos na defesa do pluralismo das formas de atendimento à saúde e da liberdade de escolha. Enfatizando a maior eficiência do setor privado vis-à-vis ao público, esses setores reagiram contra a proposta de reforma, defendendo a estrutura institucional vigente. Os diferentes atores, representantes das duas visões, são sumarizados por Rodrigues Neto (1997: 72):

As considerações e propostas feitas aos constituintes podem ser divididas em três grupos: 
- as derivadas e orgânicas com a $8^{a}$ conferência, apresentadas pela CNRS, pelo CONASS e pelas entidades sindicais, associações profissionais, conselhos federais, ABRASCO, CEBES, entre outras;

- aquelas em defesa da 'prática liberal' e da iniciativa privada, representadas pela AMB, FBH, cooperativas médicas, entre outras;

- e as institucionais, especialmente representadas pelas posições dos Ministros da Saúde e da Previdência Social, cada qual na defesa da preservação e valorização corporativa da sua pasta.

Entre os interesses institucionais corporativos mais relevantes estava a questão da unificação das instituições de saúde, que significava a absorção do Inamps pelo Ministério da Saúde e, conseqüentemente, a perda de poder do MPAS, até então responsável pela assistência à saúde previdenciária. Durante e após o processo constituinte, a questão da extinção do Inamps dentro da proposta do Sistema Único de Saúde e como conseqüência da unificação dos órgãos responsáveis pelas ações de saúde, rompendo com a segmentação institucional histórica que caracterizara a política de saúde, foi objeto de acirrada resistência por parte dos seus dirigentes.

Apesar dessas divergências, o relatório aprovado na subcomissão, cuja elaboração contou com a participação de assessores ligados ao movimento sanitário, em geral, expressou as suas propostas, aprovadas por ampla maioria. Entretanto, no âmbito da comissão temática - no caso, a saúde integrava a Comissão da Ordem Social na segunda etapa do processo constituinte - houve maior polarização, sendo que o setor privado dispunha de maior número de representantes. Mesmo assim, o movimento sanitário conseguiu aprovação de suas propostas fundamentais. Uma novidade foi a incorporação da saúde à seguridade social, sem a constituição de financiamento específico para a saúde, como pretendia o movimento sanitário, decisão que posteriormente se revelaria um estrangulamento da implantação da reforma.

A fase seguinte do processo constituinte, quando se passou à elaboração, no âmbito da Comissão de Sistematização, do anteprojeto e de projetos para discussão no plenário e posterior aprovação do texto definitivo, foi marcada por conflitos e maior mobilização popular, em razão da possibilidade de apresentação de emendas populares. Foi nesse momento que se organizou a Plenária de Saúde, com o objetivo de colher assinaturas para uma emenda da saúde. 
Se, por um lado, isso significou a incorporação de novos atores na defesa das propostas relativas às mudanças na saúde, por outro evidenciou a distância do movimento sanitário dos movimentos populares, uma vez que conseguira agregar poucos aliados fora das academias e corporações (Rodrigues Neto, 1997). Se a emenda originária da Plenária conseguiu menos de sessenta mil assinaturas, outra apresentada pelas entidades representativas dos interesses privados no setor - FBH, ABH, Abramge, Federação Nacional dos Estabelecimentos de Serviços de Saúde e Instituto de Estudos Contemporâneos da Comunidade - obteve cerca de setenta mil, indicando a agilidade e a capacidade organizativa desses interesses. ${ }^{140}$ Além da defesa do livre exercício profissional e do pluralismo de sistemas médico-assistenciais, essa emenda propunha a livre opção do indivíduo entre diversos sistemas de saúde, em confronto direto com as propostas aprovadas nas etapas anteriores. Mas o projeto aprovado na Comissão de Sistematização contemplou os principais pontos da proposta do movimento sanitário, apesar de ter sofrido vários cortes no decorrer do processo.

Entretanto, na votação em plenário - etapa final do processo decisório na Constituinte - vão se polarizar os diversos grupos de interesses. No caso da saúde, divididos, de um lado, na defesa do setor público e do sistema único e, de outro, em torno à crítica ao que consideravam como estatização, que unia o setor hospitalar privado, a medicina de grupo, as cooperativas médicas e os representantes da medicina liberal. Esse segundo grupo, entretanto, apresentava clivagens internas e se diferenciava em relação a outros aspectos, particularmente em relação à autonomia ou não ante o Estado, nesse último grupo se situando o setor hospitalar privado contratado pelo setor público (Rodrigues Neto, 1997: 83):

Ao setor hospitalar privado contratado (ou contratável) interessava o aumento da receita da Seguridade Social e uma estratégia de organização dos serviços que viabilizasse a sua participação nesses recursos, sem subordinação técnica ou administrativa ao poder público. Pelo contrário, ao setor de pré-pagamento interessava a possibilidade de captação direta dos recursos sem a intermediação do Estado, isto é, sem passar pelo 'caixa' da Seguridade Social; para tal seria necessário a não

$\overline{140}$ Rodrigues Neto (1997) compara com outras emendas populares, como a da Reforma Agrária, que obteve mais de três milhões de assinaturas, e a do Ensino Público, que teve mais de um milhão. 
compulsoriedade de contribuição para a Seguridade Social e a possibilidade de o Estado transferir a esse setor parte da sua responsabilidade na cobertura assistencial.

Insatisfeitos com o regimento interno, que dificultava alterações globais do projeto da Comissão de Sistematização, parlamentares mais conservadores, reunidos no grupo que foi denominado de 'Centrão', conseguiram alterar o regimento em pleno processo de votação em plenário. A partir daí e com base nas reivindicações do setor privado, representado por esses mesmos parlamentares, foram apresentados substitutivos que contrariavam completamente o anteprojeto anterior e, mesmo, a política de saúde em vigor. Seguiu-se uma fase de debates e negociações acirradas, além de intensa mobilização tanto por parte da plenária de saúde quanto dos representantes do setor privado. O centro da discussão era a definição da "natureza pública ou não dos serviços de saúde, com suas implicações decorrentes sobre o relacionamento entre os setores públicos e privados" (Rodrigues Neto, 1997: 84). O acordo que se conseguiu contemplou de um lado as reivindicações do setor privado, explicitando-se o direito da iniciativa privada de participar das ações de saúde, e de outro as do movimento sanitário, incluindo a exigência de contrato público para a participação complementar da iniciativa privada no Sistema Único de Saúde. A adoção do contrato público como regra jurídica de relacionamento entre o Poder Público e as instituições privadas de assistência médica indicou a soberania do Poder Público e do interesse coletivo em detrimento de interesses particulares.

Como aspectos fundamentais do texto constitucional aprovado em outubro de 1988, destacam-se: a adoção de um conceito de saúde como articulação de políticas sociais e econômicas e que não se restringe à assistência médica; o estabelecimento da saúde como direito social universal; a caracterização das ações e serviços de saúde como de relevância pública; e a criação de um Sistema Único de Saúde, organizado segundo as diretrizes de descentralização, atendimento integral e participação da sociedade. O texto constitucional refletiu os acordos entre diferentes atores, com participação importante dos constituintes que eram apoiados por pessoas e grupos que vinham construindo o projeto da reforma sanitária. Outros segmentos, particularmente o de planos e seguros privados, conseguiram resguardar a liberda- 
de de atuação da iniciativa privada no campo da assistência à saúde, ficando fora da agenda a interferência sobre o setor privado. Isso aconteceu apesar de a saúde ter assumido a condição de função pública ao definir suas ações e serviços como de relevância pública, reafirmando-se, assim, as prerrogativas do Poder Público na sua regulação, fiscalização e controle, independentemente do regime de propriedade do provedor (Fleury, 1997). Além disso, a Constituição vedou a destinação de recursos públicos para auxílios ou subvenções a instituições privadas com fins lucrativos, mas não tratou da questão dos subsídios indiretos ao sistema de saúde privado, que permaneceu no campo das não-decisões, preservando, portanto, o estado de coisas vigente.

$\mathrm{O}$ acordo entre os interesses diversos, que foi possível construir na Constituinte, traduziu-se nas ambigüidades do texto constitucional, levando, na expressão de Mendes (2001: 96), “a uma dualização jurídica”, ao criar-se um sistema público de inspiração socialista no artigo 196, em razão de um ideário do movimento sanitário de estatização progressiva do sistema de saúde, e ao mesmo tempo, no artigo 199 - que afirma que a assistência à saúde é livre à iniciativa privada -, abrir-se espaço para a expansão do sistema supletivo e da medicina liberal. A flexibilidade e a liberdade de atuação no mercado como conseqüência da 'não-decisão' de regulamentação durante o processo constituinte permitiram ao setor privado o desenvolvimento de diferentes alternativas e estratégias para captação de clientela. No mesmo artigo 199 garantiu-se a participação do setor privado no SUS em caráter complementar, aludindose isso à prestação de serviços. Ao se considerar a participação complementar, a proposta era priorizar a rede pública e a privada sem fins lucrativos. ${ }^{141}$

Paradoxalmente, ao mesmo tempo que a Constituinte reforçava o setor público na prestação de serviços de saúde, as reformas desencadeadas no âmbito da Previdência Social sofriam grande retrocesso e os representantes

\footnotetext{
141 Depoimento do presidente da Abramge-MG é esclarecedor do embate que se travou durante o processo constituinte entre as duas posições antagônicas: "Nós tivemos na Assembléia Constituinte uma atuação muito importante, porque sentíamos naquela época uma tendência estatizante muito grande. (...) E nós tivemos muita dificuldade; tivemos que fazer muito conchavo político para criar o artigo 199 da CF/88, porque no momento em que tivéssemos só o artigo 196 a iniciativa privada ficaria praticamente fora da atividade, pois nem citada ela foi. Nós conseguimos reverter esse quadro e criamos o art. 199, que garantiu à iniciativa privada a permanência de suas atividades" (entrevista realizada com José Fernando Rossi em outubro de 2002).
} 
do movimento sanitário perdiam espaços institucionais conquistados anteriormente, não permanecendo, após 1988, nenhum deles em cargos de direção. Embora as tentativas de transformação do sistema de saúde com a ocupação de espaços institucionais tenham produzido avanços no sentido da reforma sanitária, estes foram difíceis de serem mantidos no âmbito burocrático.

Isso reflete a mudança de rumo que caracteriza o segundo momento do primeiro governo civil, no qual as preocupações sociais no sentido de ampliação da democracia substantiva que tiveram força na primeira fase do governo serão substituídas pelas propostas conservadoras que tinham caracterizado o período autoritário. Tal situação, em grande medida, reflete o processo de democratização do país, caracterizado como um pacto interelites, a maioria delas sendo as mesmas que integraram o governo autoritário. No caso da saúde, não será diferente, e a reforma constitucional vai conviver com o recrudescimento de propostas conservadoras e privatistas, vinculadas aos interesses consolidados na trajetória da assistência. Com isso, ocorre um retrocesso nas mudanças institucionais que tinham começado a ocorrer após a criação do Suds no sentido da descentralização, integração institucional e reforço ao setor público na prestação de serviços, ao lado da saída de quadros políticos reformistas da Previdência Social. Será nesse quadro que se dará início nos anos 90 à implantação da reforma definida no plano jurídico-formal.

\section{A Implantação da Reforma na Década de 90}

No processo decisório que levou à mudança nas regras da assistência à saúde de caráter público, fizeram-se sentir os efeitos das políticas anteriores sobre o processo político na medida em que, ao configurar os interesses privados, as decisões anteriores alteraram o conflito político. No confronto entre 'novos' e 'velhos' atores, entendidos os últimos como aqueles constituídos no percurso da política de saúde, é que foram feitas as escolhas que definiram as novas regras formais, as quais permitiram a convivência da mudança com a continuidade. As ambigüidades do texto constitucional, que mesmo reforçando a atuação estatal preserva as formas privadas de assistência, refletem o ajustamento entre as alternativas inovadoras e os padrões consolidados. 
No momento de implantação da reforma essas ambigüidades se farão sentir e, juntamente com outros efeitos das políticas prévias, colocarão limites à implantação de um sistema de saúde efetivamente público, universal e único, conforme definido na Constituição. Passada a conjuntura especial de reordenação político-institucional do país, caracterizada por ampla mobilização em torno da democratização que favoreceu a articulação de atores diversificados, resultando em alterações substantivas nos princípios e ordenamentos da política de saúde, na década de 90 impôs-se a tarefa de transformar os dispositivos formais/legais em realidade. Mais do que uma mera tradução prática de decisões, a implantação da reforma se mostrou, de fato, como um processo ainda de formulação da política de saúde, cujo resultado será a consolidação de um sistema híbrido - público e privado - no caso da assistência à saúde, apesar da definição legal de um sistema único, público, universal e gratuito.

Para a análise desse processo, parte-se aqui do pressuposto de que a implantação de uma política exige decisão e iniciativa governamental, instrumentos para efetivá-la, entre eles a disponibilidade de recursos financeiros, e suporte político organizado, particularmente por parte dos grupos sociais afetados positivamente pela política. Nesta seção serão analisadas as possibilidades de atendimento dessas exigências para a implantação do SUS, interpretandoas com base na confluência dos efeitos da trajetória da política de saúde com fatores conjunturais de natureza econômica e política, em contexto de reformas econômicas e desfavorável à ampliação da atuação do Estado e de políticas universalistas. Os efeitos de feedback da configuração de uma determinada estrutura institucional para a assistência à saúde se manifestam de várias maneiras, afetando a disposição e a capacidade governamentais e conformando as preferências e a interpretação da realidade dos atores que poderiam dar suporte político mais ativo à implantação da reforma da saúde. Expressando essa trajetória, sugere-se que a implantação do SUS vai ser um processo cheio de contradições, no qual, ao mesmo tempo que o Sistema Único de Saúde de fato se institucionaliza e se torna uma realidade, contando inclusive com o apoio de outros atores constituídos a partir dele, sua implantação se faz em condições precárias e de forma incompleta, desvirtuando sua concepção. Paralelamente, essa análise indica outras características da dinâmica política brasileira, particularmente a distância entre o plano legal e a realidade, e a 
forma de relacionamento Executivo/Legislativo na situação de consolidação da democracia.

\section{As condições políticas de implementação da reforma}

O contexto político nacional e internacional de implantação do SUS não se mostrou favorável após sua consagração constitucional. A transição democrática no país se deu com a manutenção no poder das mesmas forças políticas conservadoras ligadas ao regime anterior, sendo que os grupos indutores da reforma, particularmente os partidos e lideranças de esquerda e parcelas dos movimentos populares, não tinham ampliado de forma considerável seu poder relativo e também não contavam de forma efetiva com antigos apoiadores do período de transição, como a categoria médica. A configuração conservadora dos governos que se sucederam no período da transição democrática estava em perfeita sintonia com o ambiente internacional, marcado pela rediscussão do papel do Estado, que se traduzia em propostas de novos modelos de políticas sociais. Do questionamento da universalização de direitos proliferaram propostas de focalização do gasto público nos setores mais pobres da população, deixando para o mercado a produção de serviços sociais destinados aos setores mais favorecidos. ${ }^{142}$ Como afirma Draibe (1995), antes que se implementassem as diretrizes da agenda de reforma social da transição democrática esgotaram-se os conteúdos de suas proposições e, ao mesmo tempo que teoricamente avançava a implementação, desenhava-se outra agenda de reformas.

Ao processo de democratização se seguiram os de ajuste e estabilização econômica, acompanhados das reformas estruturais iniciadas no governo Collor, que iam em sentido inverso à ampliação das atribuições governamentais e dos direitos sociais recém-consagrados na Constituição, em sintonia com o receituário internacional. A conjuntura de crise fiscal, com suas conseqüências sobre

\footnotetext{
${ }_{142}$ Uma boa síntese dos principais diagnósticos e recomendações de políticas sociais elaborados pelas agências multilaterais atuantes na América Latina é feita por Lopes (1994). Particularmente, as recomendações do Banco Mundial sugerem que o gasto social deve ser focalizado nos estratos mais pobres, especialmente em período de crise, sendo que a universalização é injusta ao beneficiar pessoas com necessidades e recursos diferenciados. Um exemplo de análise prescritiva das formas de intervenção do Estado no setor saúde com base no enfoque do Banco Mundial é encontrado em Musgrove (1996). A idéia defendida é que, exceto para os pobres, a intervenção pública na assistência à saúde deve ser limitada e com menor financiamento público.
} 
o financiamento dos serviços públicos, associada com o fortalecimento de posições conservadoras e voltadas para o mercado, não se mostrou favorável à implantação do SUS, limitando a possibilidade de ampliação dos serviços de saúde, necessária para garantir a universalização efetiva. Ao se traduzir na redução do gasto público, funcionou como freio objetivo e ideológico à atuação redistributiva do Estado. Particularmente o governo Collor, que assumiu em 1990 com o primeiro presidente eleito após o regime autoritário, foi caracterizado por tentativas de desmontar as políticas sociais e pelo desaparelhamento do Estado, afetando o andamento da reforma sanitária definida no plano legal.

A regulamentação do texto constitucional foi retardada, existindo setores contrários à implementação do SUS dentro do próprio governo, além de divergências intraburocráticas na forma de sua operacionalização. Foi necessária forte atuação dos grupos pró-reformas com os parlamentares para se conseguir a aprovação da Lei Orgânica da Saúde, que só ocorreu dois anos depois da promulgação da Constituição e em duas etapas (leis 8.080/90 e 8.142/90), demonstrando o embate político necessário para tornar o SUS realidade. Aprovada uma primeira versão (lei 8.080/90), a Lei Orgânica teve artigos importantes vetados pelo presidente da República, e somente após pressão e articulação da Plenária das Entidades de Saúde e de outros órgãos, particularmente o Conasems, é que foi apresentado e aprovado novo projeto de lei (lei 8.142/90) contemplando a regulamentação dos dispositivos constitucionais vetados anteriormente. ${ }^{143}$ No conjunto, essa legislação se limitou ao sistema público de saúde deixando de regular o sistema privado autônomo. Os mesmos grupos que atuaram na Constituinte - particularmente governo, movimento da reforma sanitária, secretários municipais e empresários de saúde - buscaram influenciar o processo de tramitação da Lei Orgânica, negociando com os parlamentares no âmbito da Comissão de Seguridade Social.

$\mathrm{Na}$ regulamentação da Lei Orgânica, por meio de uma Norma Operacional, foram estabelecidos mecanismos que, de acordo com a avaliação de muitos autores (Carvalho, 1996; Gerschman, 1995) representaram um retrocesso em relação à Constituição, além de contrariá-la. Entre eles, mantinha-se a

\footnotetext{
${ }_{143}$ Os artigos vetados referiam-se à participação social via conferências e conselhos, à transferência automática de recursos para estados e municípios, além da extinção do Inamps e da descentralização de órgãos como a Superintendência de Campanhas (Sucam) e a Fundação de Serviço Especial de Saúde Pública (Fsesp) - redutos conservadores nas instituições de saúde.
} 
gestão de recursos da saúde pelo Inamps, instituição-símbolo do modelo assistencial anterior, transferido para o Ministério da Saúde em 1990, mas que só foi extinto formalmente em 1993.

Em 1992, foi realizada a IX Conferência Nacional de Saúde, que exerceu um papel importante no sentido de mobilizar a sociedade pela implementação da reforma. O evento teve efeitos positivos, pois após a conferência o Executivo, pressionado, deu início ao processo de operacionalização do SUS. O tema central da conferência foi a municipalização, uma das diretrizes básicas da reforma e politicamente considerada um mecanismo institucional fundamental para tornar "a Reforma menos vulnerável ao nível central de decisão" (Gerschman, 1995: 140). Ao propiciar deslocamento de poder e facilitar a participação da sociedade na gestão, a descentralização poderia garantir a sustentabilidade da reforma.

O Conselho Nacional dos Secretários Municipais de Saúde (Conasems) assumiu a coordenação da comissão organizadora da conferência, tendo sido então o ator que demonstrou maior estruturação e articulação política. Desde a década de 80 , o movimento municipalista em saúde ${ }^{144}$ vinha se organizando, alimentado por experiências de saúde bem-sucedidas em alguns municípios e pelo fortalecimento dos municípios em conseqüência da experiência das AIS, que possibilitou a constituição de uma rede de contatos entre secretários municipais de saúde. A criação do Conasems como órgão de representação nacional ocorreu após já terem sido criadas entidades congêneres em alguns estados. No final da década de 80, foram realizados vários Encontros de Secretários Municipais de Saúde de caráter regional e nacional, que tiveram grande repercussão política e reforçaram o movimento em prol da reforma sanitária, a partir do eixo da municipalização. O movimento de secretários municipais será bastante fortalecido após a reforma constitucional, que colocou o município como ator central na política de saúde. ${ }^{145}$ Como a reforma tinha como

\footnotetext{
144 Por movimento municipalista de saúde se entende “a articulação, união e organização dos municípios brasileiros, em particular dos serviços municipais de saúde através de seus dirigentes e técnicos, na defesa de um conjunto de temas e objetivos relacionados à descentralização de recursos, de poder e ações no Setor Saúde” (Muller, 1991, apud Goulart, 1996: 15).

145 De acordo com depoimento de Eugênio Vilaça Mendes em 1995 (Goulart, 1996: 67), se a VIII Conferência tinha sido "feita e conduzida por uma elite de doutrinadores, um grupo restrito de pessoas, o chamado Movimento Sanitário (...) a IX foi feita por um conjunto de atores sociais emergentes, verdadeiros novos atores. Quem são? Os secretários municipais de saúde que amarraram a Conferência, que a bancaram e sinalizaram o tema".
} 
uma de suas diretrizes a descentralização, que tomou a forma de municipalização, o Movimento Municipalista da Saúde obteve apoio da Frente Nacional de Prefeitos, que viu na implantação do SUS a possibilidade de obtenção de recursos e de maior autonomia aos gestores municipais. A ênfase na descentralização levou, assim, à adesão dos secretários municipais de saúde e prefeitos à reforma sanitária - nem sempre por motivações ideológicas, mas muitas vezes pela possibilidade de captação de recursos.

Isso significa que no processo de implementação do SUS atores governamentais de âmbito local foram incorporados como seus apoiadores. ${ }^{146}$ Ao mesmo tempo, atualizaram-se as divergências dos interesses em jogo no setor saúde, que durante o movimento pela redemocratização do país tinham sido escamoteados por causa da agregação em torno da retomada do regime democrático e da reforma sanitária. Na implantação da reforma, o jogo político se daria muito mais em razão das demandas derivadas de interesses específicos, e não mais com base em um projeto ético de caráter coletivo. A desarticulação das discussões travadas no âmbito da IX Conferência desnudou a

heterogeneidade na composição e nos posicionamentos políticos do movimento social em saúde, à qual se agregou a fragilidade do 'Movimento Sanitário' - numa fase de declínio, depois de ter conseguido, durante mais de dez anos, exercer a condução do movimento social em saúde - e a ausência de uma orientação política reconhecida pelo conjunto do movimento social em saúde. (Gerschman, 1995: 144) 147 $^{147}$

146 Depoimento de Gilson Carvalho, um dos principais expoentes do Movimento Municipalista da Saúde, em 1995, parece sugerir uma intenção mais formal do que real de se implantar o SUS: "Eu tenho uma hipótese: na aprovação do SUS na Constituição de 88 e também na LOS, a classe política não imaginava os desdobramentos do que se propunha, pois nosso movimento ainda era fraco e pouco respeitado. E havia a grande dificuldade de se contar com gente, quadros que pudessem levar a proposta adiante. E também ter recursos para tanto. Mas o movimento [municipalista] surpreendeu a todos, que 'não imaginavam que nós poderíamos tirar a realidade do papel e fazer o SUS”' (Goulart, 1996: 68, destaque meu).

147 Stralen (2000: 36) sintetiza bem as dificuldades políticas de implantação do SUS: "não há dúvida de que a construção de um sistema de saúde com acesso universal e eqüitativo tem como condição sine qua non um amplo arco de alianças. Era também isso que faltava ao movimento [sanitário]. Além de enfrentar oposição ferrenha do setor privado, o movimento, cuja unidade era forjada principalmente pela existência de um inimigo comum - a ditadura militar -, de fato não contava com o apoio massivo da corporação e nem dos sindicatos de trabalhadores de empresas de ponta. Quanto à corporação médica, faltou uma política de cooptação tal como realizada por exemplo na Inglaterra e Suécia quando ali foram criados sistemas públicos de saúde. E quanto aos sindicatos, prevalecia a preocupação com a garantia de assistência médica a princípios ideológicos. Assim, o avançar do processo de (re)democratização que colocou em evidência interesses divergentes e conflituosos contribuiu à morte lenta e segura do movimento sanitário." 
Entre as principais alterações do movimento sanitário no momento de implantação da reforma, destacam-se: as divergências partidárias em decorrência do fortalecimento e da diversificação das identidades partidárias propiciados pela democratização; o distanciamento da academia da prática política, que tinha sido o elemento impulsionador do movimento; e as modificações dos movimentos dos profissionais de saúde, com o deslocamento do eixo das lutas políticas dos sindicatos para os conselhos de medicina e com o distanciamento ideológico dos princípios da reforma sanitária concomitante ao aprofundamento do corporativismo, passando a se orientar por questões mais pragmáticas relativas ao exercício da profissão (Gerschman, 1995). Com a despolitização das instituições médicas no final da década de 90, na conjuntura de pós-transição, as profundas diferenças na categoria inviabilizaram a possibilidade de uma ação unificada, e o movimento médico se distanciou do projeto básico da reforma sanitária no momento crucial de sua implementação. Após a aprovação da Lei Orgânica da Saúde, o movimento sanitário não teve mais uma atuação contínua e regular na legislação infraconstitucional, afastando-se do debate parlamentar (Rodrigues Neto, 1997).

Por sua vez, o movimento popular em saúde já se esvaziara desde a década anterior, em razão de suas cisões internas, e não foi capaz de garantir o apoio dos usuários dos serviços de saúde à reforma constitucional. Contribuiu para isso não apenas a fraca mobilização política do Mops, mas a própria característica da reforma, que fez com que os seus benefícios fossem muito dispersos e só perceptíveis a longo prazo pelo conjunto da população, o que levou os responsáveis pela reforma a não poderem contar com o apoio mobilizado do público-alvo da política de saúde. O baixo grau de envolvimento dos usuários limitou também a constituição de mecanismos de pressão e resistência diante dos obstáculos postos à implementação da reforma, particularmente a contenção sistemática de gastos com o setor (Fundação João Pinheiro, 1999).

Acresce-se a isso o fato de que alguns atores, apesar de garantirem o apoio formal à reforma sanitária, não se constituíram de fato em seus apoiadores efetivos, mergulhados nas contradições entre a postura ideológica igualitária e a defesa de seus interesses corporativos. Entre esses, destaca-se o movimento sindical mais combativo, no âmbito tanto do setor privado quanto 
do público, cujas categorias, em grande parte cobertas por planos privados de saúde, no âmbito das empresas e instituições públicas, não seriam diretamente beneficiadas com a implantação do SUS. Na medida em que a assistência privada possibilita maior facilidade de acesso, esses atores não têm incentivos concretos para apoiar de forma mais efetiva o sistema público.

A proposta de um sistema de saúde igualitário chocou-se com o legado histórico de uma sociedade marcada pela diferenciação e pela segmentação no próprio campo da atenção à saúde, no qual o processo de inclusão se deu pela incorporação de segmentos privilegiados dos trabalhadores assalariados. Como destaca Mendes (2001), as reformas sanitárias têm um forte componente ideológico e expressam valores societais vigentes que, grosso modo, opõem-se entre valores individualistas e auto-interessados e valores solidaristas. ${ }^{148}$ No caso brasileiro, a reforma sanitária foi de inspiração claramente solidarista e com pretensões transformadoras que extrapolavam o setor saúde. Entretanto, não se pode dizer que esses valores estavam generalizados tanto na elite governante como na sociedade organizada. Ao contrário, como herança de políticas anteriores, tinham se desenvolvido práticas e, conseqüentemente, valores pouco solidaristas, e não se constituíra uma demanda de atenção universal entre os segmentos organizados dos trabalhadores. A origem da Previdência Social no país, na qual se inseriu a assistência médica, não foi o resultado da constituição prévia do sentimento de pertencimento a uma comunidade, mas sim uma forma de o governo getulista buscar apoio de setores até então excluídos do jogo político pela via da corporativização das demandas dos trabalhadores. A história do alargamento dos benefícios previdenciários, entre eles a assistência médica, é também uma história de pressões dos trabalhadores mais organizados no

148 O sentido das reformas é dado pelos valores, entendidos como sistemas de crenças, sendo que a estabilidade dos sistemas sociais, entre eles o de saúde, resulta da coerência entre os valores societais e as estruturas simbólicas e materiais desses sistemas. Em cada caso há também, conseqüentemente, uma concepção do papel do Estado e do mercado no financiamento, regulação e prestação dos serviços. Nos sistemas de saúde baseados nos valores individualistas tendem a prevalecer mecanismos de mercado pela via da competição, com a conseqüente constituição de sistemas segmentados que segregam diferentes clientelas e no qual cada segmento exerce as funções de financiamento, regulação e prestação de serviços. Prevalecendo valores solidaristas, a tendência é por uma participação diferenciada no financiamento e no acesso de acordo com as capacidades econômicas e nível de risco, oferecendo serviços com base na necessidade e mediante subsídios cruzados. Os sistemas de saúde baseados nesses valores tendem a ser públicos e universais. O modelo segmentado se expressa em alto percentual de população coberta por sistemas de seguros privados e por baixa participação relativa dos gastos públicos sobre o gasto total em serviços de saúde (Mendes, 2001). 
sentido de obter ganhos diferenciados para cada categoria, situação propiciada pela própria configuração institucional da Previdência Social, construída da segmentação por categorias. Conquistas ou concessões de benefícios sociais diferenciados faziam parte do jogo político e eram usadas como moeda de troca, não tendo se constituído em um projeto de cidadania inclusiva.

Essa origem da assistência calcada na diferenciação, primeiro no âmbito da assistência pública por meio dos IAPs e posteriormente em razão da distinção entre trabalhadores cobertos por planos empresariais e cobertos pela assistência pública, não favoreceu a constituição de uma identidade coletiva e uma de valores que enfatizassem a solidariedade e o igualitarismo que pudessem dar suporte à reforma, que, pelo seu caráter redistributivo, demandaria coalizões mais amplas. ${ }^{149} \mathrm{O}$ projeto de ruptura no padrão de intervenção estatal na área da saúde se confrontou com o desenho histórico da cidadania regulada, além do que a reforma foi feita com a constituição de alianças políticas restritas e sem a participação decisiva de atores fundamentais, como os trabalhadores organizados, caracterizando um modelo de construção de reformas pelo 'alto', típico da transição brasileira, ${ }^{150}$ ao mesmo tempo que não existia "um projeto nacional de desenvolvimento que tomasse a questão da desigualdade e da exclusão como o cerne da questão democrática” (Fleury, 1997: 34).

Essa situação criaria grandes obstáculos para a concretização da agenda redistributiva, reafirmando o modelo segmentado de assistência médica no qual os principais beneficiários eram exatamente os trabalhadores das grandes empresas da região Sudeste, onde também se desenvolveu o movimento sindical mais ativo. Analisando as reivindicações de trabalhadores na década de 80, período de afirmação do projeto da reforma universalista, Costa (1995) identificou a constituição de arenas em que atores sociais buscaram assegurar formas privilegiadas e exclusivas de acesso a benefícios sociais, entre eles a

\footnotetext{
149 Paci (1986, apud Vianna, 1998) destaca que o papel fundamental da oferta pública de bens e serviços vai além de seus efeitos redistributivos e incide diretamente sobre o sistema de valores dominantes na sociedade, introduzindo elementos de igualitarismo e solidariedade.

150 Depoimento de um participante do movimento da reforma sanitária, do sindicato médico, é elucidativo da fragilidade da participação do movimento sindical: "é importante frisar que o movimento sindical de trabalhadores urbanos (bancários, metalúrgicos, etc.) participaram [sic] da luta pela reforma sanitária de uma forma secundária, não como um interesse central. Os trabalhadores dos sindicatos e das categorias mais avançadas, no Brasil, nunca estiveram interessados no sistema sanitário público. E isso debilitou profundamente a luta sanitária no Brasil" (Sindicato dos Médicos, 2000).
} 
assistência médica. Entre os benefícios indiretos que muitos trabalhadores foram capazes de conseguir no período 70/80 figuraram os planos de saúde, potencializando o desenvolvimento de uma oferta diferenciada e estratificada de serviços para os segmentos de maior poder de barganha, na contramão do projeto universalista e gerando uma tensão com essa agenda publicista. Nas décadas de 80 e 90, a demanda por assistência médica diferenciada da pública transformou-se em item da agenda de negociação coletiva. ${ }^{151}$

Paradoxalmente, essa agenda auto-referida das representações sindicais ocorreu num contexto de institucionalização da representação sindical nos fóruns de gestão e formulação das políticas de saúde. Embora nesses fóruns formais teses publicistas fossem defendidas, na ação concreta constituíram um 'veto implícito’ ao modelo público e universal e fortaleceram a assistência diferenciada prestada pelas empresas. ${ }^{152}$

151 Essa idéia foi reforçada em entrevista com a diretora de saúde do Sindicato dos Trabalhadores em Telecomunicações (Sintel) e membro do Coletivo de Saúde da CUT-MG, realizada em dezembro de 2002, que identifica uma 'cultura de planos de saúde', os quais se tornaram uma demanda dos trabalhadores, que dificilmente encontra resistência das empresas. Para Costa, um determinante dessa tendência é a opção ativa pelo atendimento diferenciado das organizações que articulam interesses, como os sindicatos e as associações profissionais e funcionais, associada a uma 'cultura da diferenciação', que estaria na gênese da cultura associativa sindical. Para corroborar sua hipótese, utiliza dados de convenções coletivas de 1989 e 1990, nas quais não aparece nenhuma referência às políticas de saúde que considerem a população fora do processo produtivo, embora elas contenham pautas de saúde do trabalhador extremamente inovadoras. Nas convenções de quatro sindicatos de São Paulo, estão incluídos entre as cláusulas de saúde os convênios médicos. Em outros acordos identificou a preocupação de garantir o direito à assistência no caso de perda de emprego, o que indicaria que a demanda por serviços supletivos de saúde tornou-se um componente implícito das negociações entre capital e trabalho, em um distanciamento ativo da agenda publicista. Além disso, Costa (1995) cita uma pesquisa da Central Única dos Trabalhadores (CUT), s.d., que revela que quase metade dos sindicalizados da Grande São Paulo dos setores metalúrgico, químico, construção civil, têxtil, bancário, comerciário e transporte coletivo identificava como principal motivo para entrada no sindicato a possibilidade de acesso a serviços sociais.

152 Questionando Costa, Bahia (1999) considera que as reivindicações que ele identifica nas pautas de negociação de sindicatos são, provavelmente, para manutenção/renovação/ampliação de cobertura de planos já existentes e menciona estudos das convenções coletivas de trabalho de algumas categorias em São Paulo onde não constam os planos/seguros privados de saúde (Checcia, 1996; Almeida, 1980). Para ela, “as informações imprecisas sobre a participação dos sindicatos de trabalhadores no estímulo aos convênios das empresas empregadoras com empresas médicas e seguradoras não permitem atestar uma opção ativa movida por uma estrutural e genética cultura pela diferenciação inerente ao associativismo brasileiro. Formalmente, a assistência médica suplementar não parece resultar de 'uma conquista' pós-explicitação de conflitos entre empregados e empregadores e sim da opção espontânea das empresas” (Bahia, 1999: 30, grifos da autora). Entretanto, o mesmo argumento arrolado por Bahia para questionar Costa pode também ser considerado válido para a sua interpretação que parte de uma suposição. A carência de dados sobre a data de origem dos planos de saúde de empresa que possam ser confrontados com as convenções coletivas não permite validação de nenhuma das hipóteses, embora os argumentos de Costa sejam logicamente bastante consistentes e corroborados por outros dados. 
A postura oficial do movimento sindical mais combativo, representado pela Central Única dos Trabalhadores, foi e continua sendo de defesa do sistema público e de diretos igualitários, embora na prática isso não venha se traduzindo em uma mobilização mais efetiva pela concretização dos princípios do SUS. A discussão da saúde no cotidiano dos sindicatos tem se centrado nas questões da saúde do trabalhador, vinculadas às condições de trabalho e aos benefícios previdenciários, que passaram a consumir muito das energias do movimento sindical, em face da sua vulnerabilidade e do acúmulo de perdas com o aumento do desemprego desde os anos 90. Pela participação nos fóruns colegiados da estrutura do SUS, as lideranças do movimento sindical se integram ao SUS, mas a questão não parece atingir a categoria como um todo. Essa contradição entre os interesses imediatos e a orientação político-ideológica de defesa das ações públicas de cunho universalista torna o tema da assistência à saúde bastante polêmico e obscuro no movimento sindical. ${ }^{153}$

Esse mesmo paradoxo aparece de forma ainda mais expressiva, por se tratar dos atores encarregados da operacionalização da assistência médica pública, nas entidades representativas dos servidores públicos das instituições previdenciárias. Desde o antigo IAPI, os servidores da Previdência Social e, posteriormente, do Ministério da Saúde são cobertos pela Geap, o maior plano de autogestão do país e um dos mais antigos. Apesar da defesa radical de um sistema único e público nos fóruns formais da categoria, na prática concreta os beneficiários da Geap, por intermédio de suas entidades representativas, sempre defenderam duramente o que consideravam 'direitos adquiri-

153 Entrevista com a diretora de saúde do Sintel, já citada, é elucidativa dos conflitos vividos pelos sindicatos em momento de enfrentamento de muitas perdas: "A questão da saúde pública está dentro do debate da CUT, mas no âmbito político e de denúncia. Não se discute, por exemplo, implantar uma ação mobilizando as massas de maneira geral, não existe uma ação de peso para obrigar a mudar. Hoje são os sindicatos mais ligados à saúde pública que fazem essa discussão. Se eu não estou dormindo na fila para ser atendido, não tenho disposição suficiente para enfrentar o governo na prioridade à saúde. Plano de saúde no sindicato é uma coisa muito polêmica; havia uma resistência muito grande na CUT ao plano de saúde. Sabe aquela coisa que todo mundo sabe que está errado, mas tem uma cortina de fumaça... O plano de saúde é do interesse da empresa, pois de certa forma é uma maneira de segurar o empregado. Nunca precisou brigar por plano de saúde mas muita gente fica nas empresas por causa de plano. De uns tempos para cá, as pessoas se acostumaram tanto com plano de saúde que hoje trabalhador nenhum quer ficar sem e o plano de saúde está virando uma cultura. As pessoas estão se acostumando com a idéia de ligar para um médico e ter uma consulta rápida, se precisar internar ter a segurança de que vai ser internado." 
dos' de uma assistência médica diferenciada e de maior qualidade. ${ }^{154}$ Essa ambigüidade, na prática, torna a defesa do sistema público quase que mera retórica, retirando-lhe de fato essa importante base de apoio no seio da própria instituição governamental encarregada da assistência médica pública. ${ }^{155}$ Ao contrário de experiências em outros países, pelo menos no caso da saúde o sistema público não encontrou nos servidores públicos defensores importantes das políticas sociais, já que grande parte deles estava coberta há muito tempo por políticas diferenciadas.

O processo de descentralização desencadeado pela reorganização do sistema de saúde após a criação do SUS teve o impacto inicial de deslocar para o nível local a execução da política de saúde, pulverizando as instituições responsáveis pela assistência à saúde. Isso pode ter tido um efeito imediato, particularmente após a extinção do Inamps, de desagregar o suporte institucional ao SUS. Por sua vez, a descentralização tem provocado o surgimento de novos apoiadores do SUS no nível das prefeituras e das instâncias colegiadas que se organizaram com base em definições legais no sentido de incluir a participação da sociedade na gestão do SUS. Esse processo de constituição de novos sujeitos na arena da saúde é ainda recente para que possa surtir resultados que alterem a dinâmica política de forma a reforçar o SUS em detrimento do processo de segmentação das clientelas a partir do fortalecimento do setor privado. E ainda nessa arena local os funcionários das prefeituras, em muitos casos, também estão cobertos por planos coletivos particulares.

Mais recentemente, pesquisa com os membros do Conselho Municipal de Saúde de Belo Horizonte, o CMS/BH (Fundação João Pinheiro, 1998), constatou que os representantes dos trabalhadores de saúde (funcionários da Secretaria municipal de Saúde, muitos originados do ex-Inamps) freqüentemente assumiam uma atitude corporativa, no âmbito do CMS, nas questões que envolviam suas condições de trabalho e seus rendimentos, muitas vezes em posi-

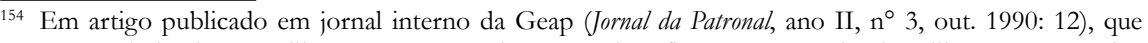
tem o título de "Os dilemas em torno da Patronal", afirma-se: "O primeiro dilema que envolve assumir a defesa da Patronal diz respeito ao aparente paradoxo de, por um lado, lutarmos por uma assistência diferenciada, mais cara e de melhor qualidade do que a que é prestada à população em geral através da rede pública. Por outro lado, em termos gerais, defendemos uma melhor assistência pública considerando a saúde como um direito de cidadania e um dever do Estado."

155 A esse respeito, ver trabalho de Menicucci (1987) com o sugestivo título: Assistência Patronal: a negação da previdência social no seu próprio seio. 
ção contrária aos interesses dos representantes dos usuários do SUS. Conselheiros entrevistados assumiram que o envolvimento efetivo desses trabalhadores com a defesa do SUS e o suporte do movimento sindical, também representado no conselho, de fato se torna difícil, na medida em que os setores mais organizados e os servidores municipais têm assistência médica diferenciada.

\section{O financiamento do SUS como forma de inviabilização sistêmica}

A operacionalização da reforma da política de saúde implicava transformações político-institucionais e organizacionais de grande envergadura. O grande esforço inicial foi promover a descentralização de uma política de longa tradição centralizadora, questão que se tornou o eixo central da implantação da reforma como estratégia para promover a participação da sociedade, alcançar a universalização e tornar as políticas mais eficazes. Para o alcance dos objetivos finalísticos da reforma, o financiamento do SUS é um recurso imprescindível e tem sido o ponto central da discussão política sobre o sistema público, envolvendo não apenas o volume, mas também a forma de repasse dos recursos do governo federal para estados e municípios, uma vez que a descentralização se fez na dependência dos recursos federais - principais responsáveis pelo financiamento das ações de saúde. ${ }^{156}$

A discussão do financiamento do SUS realizada nesta seção considera tanto a perspectiva da disponibilidade de recursos quanto a disposição governamental para a viabilização de uma política, avaliada por meio da definição de mecanismos ou fontes de financiamento.

Grande parte das demandas e críticas sobre o sistema de saúde após a criação do SUS é dirigida ao seu financiamento, a cujas deficiências são creditadas as principais dificuldades para sua implantação e para garantir o direito à saúde. Em um contexto de programas de estabilização e de ajuste fiscal, caracterizado pela realização de cortes nas despesas públicas, particularmente por causa da redução dos gastos sociais, tornou-se sedutor atribuir a esse panora-

\footnotetext{
56 De acordo com o Ministério da Saúde, até o final da década de 80 os recursos federais respondiam por mais de $80 \%$ das dotações orçamentárias destinadas ao financiamento do sistema de saúde, reduzindo-se para cerca de $70 \%$ na década de 90 em conseqüência do processo de descentralização (MS/Secretaria de Gestão de Investimentos em Saúde, 2001).
} 
ma geral a deficiência de recursos para a viabilização do SUS. Ainda mais quando, efetivamente, não se garantiu o maior aporte de recursos necessários para efetivar a universalização de cobertura e a realização da reforma sanitária, que seria "impensável sem os investimentos necessários à ampliação da rede pública de serviços" (Paim, 1991, apud Fleury, 1997: 14). Em uma conjuntura de revalorização do mercado para a produção de bens e serviços, que no caso da saúde assumiu a forma da proposta de separação entre o financiamento público e a provisão privada, essa ampliação da rede pública foi excluída da agenda pública.

Sem negar esses constrangimentos políticos, ideológicos e econômicos à concretização de um sistema de atenção à saúde que, dadas as suas intenções universalistas e igualitárias, tem o caráter claramente distributivo, parece pertinente indagar em que medida havia de fato a intenção governamental de implantar os dispositivos formais da política de saúde estabelecida, mas que seria inviabilizada pelas limitações financeiras. $\mathrm{O}$ argumento desenvolvido aqui é que mesmo não negada no discurso, nem mesmo tendo sido objeto de uma redução programática, a atenção à saúde universal e igualitária não obteve condições objetivas de se efetivar, sendo objeto de um veto implícito e de uma inviabilização sistêmica. A ausência de mecanismos efetivos e estáveis para o financiamento do SUS funcionou como um mecanismo indireto para a redução de seu alcance e efetividade. No processo de sua implantação, apenas em raras ocasiões foram questionados os fundamentos básicos do SUS, que no nível discursivo passou a ser considerado uma grande conquista social, como pode ser observado em todo o material empírico utilizado, particularmente os depoimentos no Congresso Nacional em diferentes ocasiões e partindo de diferentes atores. ${ }^{157}$ Não obstante algumas

\footnotetext{
157 Algumas tentativas de mudanças estruturais no SUS partiram do governo federal, mas que não lograriam apoio para serem encaminhadas, como a PEC 32, propondo alterar o artigo $196 \mathrm{da}$ Constituição e que visava estabelecer limites ao direito à saúde e restringir o dever do Estado na provisão das condições para seu exercício. Essa PEC não foi aceita pela Comissão Especial, criada para emitir parecer em matéria de mudança constitucional, em razão das pressões sociais, o que levou o governo a retirá-la da pauta. Outra tentativa foi a proposta de reforma administrativa para a saúde que visava à separação entre a assistência ambulatorial e a hospitalar, a reconstituição de um órgão federal para geri-la e a transformação de todas as unidades hospitalares em organizações sociais. Também essa proposta foi modificada, mantendo a alternativa de conversão em organização social. Em reunião do CNS, realizada em fevereiro de 1997, o presidente da República explicitou uma posição diferente quanto aos princípios do SUS, trazendo de volta teses que preconizam o sistema público para pobres e excluídos e atendimento aos demais por um sistema privado.
} 
manifestações de mudanças de postura quanto à universalidade e à integralidade da assistência a ser garantida pelo SUS, o discurso dominante, em geral, não questiona seus fundamentos básicos. Entretanto, essa defesa se torna vazia em termos concretos de efetivação da política, na medida em que a questão do financiamento se tornou o seu 'calcanhar-de-aquiles'. A ausência de fontes estáveis de financiamento vis-à-vis ao aumento da demanda a partir da universalização da cobertura levou a uma degradação da qualidade dos serviços de saúde bastante acentuada nos primeiros anos do SUS, refletindo os baixos valores da remuneração dos serviços realizados por prestadores públicos e privados, aliados aos constantes atrasos nos repasses da União para estados e municípios.

Com o panorama político, normativo e institucional descrito, não é razoável supor que houvesse, de fato, a intenção de reverter as características do modelo de atenção à saúde. Mas, dado o custo político de uma redução programática das propostas do SUS, em um quadro de consolidação da democracia, a estratégia indireta de inviabilização sistêmica, não garantindo o aporte de recursos necessários à operacionalização do SUS, parece consistente. A descrição da trajetória do financiamento feita a seguir esclarece o meu argumento.

Ao definir um orçamento específico para a Seguridade Social, que, além da Saúde, inclui a Previdência e a Assistência, a Constituição buscou assegurar fontes para seu financiamento. ${ }^{158}$ Mas às restrições orçamentárias, em razão da crise econômica que caracterizou o período, somou-se o desvio de recursos da seguridade social por diferentes mecanismos, como: sonegação ou inadimplência das empresas; utilização de recursos da seguridade social para cobrir despesas do orçamento fiscal ou para outros ministérios; e retenção de recursos do seu orçamento. Por causa das perdas decorrentes do novo federalismo fiscal após a Constituição de 1988, que transferiu recursos para estados e

\footnotetext{
58 “O orçamento da Seguridade Social tem como fontes as contribuições sociais, sendo mais importantes a Contribuição de Empregados e Empregadores sobre a Folha de Pagamento, a Contribuição para o Financiamento da Seguridade Social - COFINS, a Contribuição Social sobre o Lucro Líquido das Pessoas Jurídicas, o PIS, o PASEP, parte da arrecadação dos Concursos de Prognóstico, 50\% do Seguro Obrigatório de Acidentes Automotivos, a Contribuição para o Salário Educação, a Contribuição do Plano de Seguridade Social dos Servidores e, a partir de 1997, a Contribuição Provisória sobre Movimentação Financeira - CPMF” (Fundação João Pinheiro, 1999: 107). Mais recentemente, a EC 29/2000 vinculou recursos orçamentários dos três níveis de governo para a saúde.
} 
municípios, a União passou a disputar os recursos das contribuições sociais que representam mais da metade da sua receita tributária (Azevedo \& Melo, 1997).

Mas a própria configuração institucional da destinação de recursos para o segmento saúde tornou-o fragilizado diante do segmento previdenciário da Seguridade Social e do Executivo federal, na medida em que não era o arrecadador de nenhuma de suas receitas e não foram definidas vinculações explícitas para a saúde dentre as diversas fontes que compõem o orçamento da seguridade. ${ }^{159}$

A partir de 1988, houve um crescimento acentuado dos valores arrecadados pela Seguridade Social, refletindo as alterações constitucionais, mas que não se refletiu na mesma proporção no segmento saúde, que se caracterizou por grande instabilidade na alocação de recursos federais - responsáveis por aproximadamente $2 / 3$ dos recursos gastos pelo SUS. ${ }^{160}$ Recursos públicos para a saúde, que já eram poucos, não foram significativamente ampliados de forma a garantir o cumprimento dos dispositivos constitucionais, tendo mesmo havido redução no início da década.

Com a transferência do Inamps para o Ministério da Saúde e com sua extinção posterior, fragilizou-se mais ainda o SUS do ponto de vista financeiro. A perda do controle sobre a assistência à saúde pelo Ministério da Previdência Social, responsável pela arrecadação de mais da metade dos recursos do Orçamento da Seguridade Social, por meio da contribuição de empregados e empregadores sobre a folha de pagamento, levou também ao descompromisso em relação à saúde. Sob a alegação de que esses recursos tinham designação exclusiva para o pagamento dos benefícios previdenciários (aposentadorias e pensões), a partir de maio de 1993 o Ministério da Previdência Social suspendeu unilateralmente o repasse dos recursos sobre a folha de paga-

\footnotetext{
159 Nas suas disposições transitórias, a Constituição apenas estabeleceu no artigo 35: "Até que seja aprovada a lei de diretrizes orçamentárias, trinta por cento, no mínimo, do orçamento da seguridade social, excluído o seguro-desemprego, serão destinados ao setor saúde" (Brasil, Constituição Federal, 1988). Esse percentual correspondia ao mesmo que historicamente o Inamps vinha gastando do orçamento da Previdência Social antes da reforma sanitária, que desvinculou a assistência à saúde da Previdência, e foi mantido até 1993.

${ }_{160}$ Os valores arrecadados pela Seguridade Social passaram de 6\% do PIB em 1988 para 11\% em 1996. Mas no mesmo período o gasto federal com saúde caiu de 2,31\% do PIB para 1,77\% (Fundação João Pinheiro, 1999). Embora tenha se verificado um crescimento dos gastos com saúde no período de 1987/1989, dá-se uma redução a partir desta data, caindo de US\$11,3 bilhões em 1989 para US\$ 6,5 bilhões em 1992, exatamente no início da implantação do SUS. O patamar do período pré-constitucional só foi superado em 1995, quando o gasto federal em saúde atingiu US\$16,2 bilhões, o equivalente a US\$ 104,1 per capita (Lucchesi, 1996).
} 
mento para o custeio das ações de saúde, vinculando esses recursos arrecadados pelo INSS exclusivamente à cobertura dos gastos com a Previdência. Nesse mesmo ano, o presidente da República vetou o artigo da Lei de Diretrizes Orçamentárias que destinava 30\% dos recursos do Orçamento da Seguridade Social para a saúde, sob a alegação de ser contrário ao interesse nacional. ${ }^{161}$

Outras fontes do Orçamento da Seguridade Social, como a Contribuição sobre o Lucro Líquido e a Contribuição do Financiamento Social, além de disputadas por outras áreas do governo, enfrentaram questionamento jurídico no meio empresarial no início dos anos 90, cuja conseqüência foi a indisponibilidade desses recursos por algum tempo. A crise gerada nesse momento provocou uma discussão sobre a necessidade de novas e estáveis fontes de financiamento para a saúde. Mesmo supondo que a efetivação da reforma sanitária nos termos propostos por seus idealizadores não figurasse na agenda concreta de ações e escolhas, o mau funcionamento do sistema de saúde público passou a ser uma das faces mais vulneráveis da política social do governo. Apesar dos avanços expressivos em termos de cobertura, da realização de serviços, dos ganhos nos indicadores de saúde e da maior racionalidade e eficiência na gestão dos recursos propiciadas pela descentralização e incorporação do controle democrático por meio do modelo de gestão participativa que fez parte da reforma, os problemas do SUS ganharam muita visibilidade e passaram a ser denunciados em diferentes perspectivas - inclusive pelas operadoras de planos privados que os utilizaram como importante estratégia de marketing (Bahia, 1999). ${ }^{162}$

161 As LDOs até 1993 mantiveram essa vinculação, conforme previsto nas Disposições Transitórias da $\mathrm{CF}$, sem que isso tivesse surtido efeito prático na alocação de recursos, uma vez que várias atividades, como merenda escolar e pagamento de docentes de hospitais universitários, eram contabilizadas como gastos em saúde (Carneiro, 2001).

162 A precariedade das informações anteriores à implantação do SUS dificulta a mensuração dos seus resultados imediatos. Dados trabalhados por Déa Mara Carvalho, em 1998, fazem algumas estimativas nesse sentido. Depois de 1990, quando se iniciou de fato a concretização do SUS, mesmo com as dificuldades de financiamento, estima-se que houve aumento da cobertura em atenção básica da ordem de 30\%; a cobertura vacinal de menores de um ano ampliou em quase 50\%; o controle pré-natal por pessoal treinado, em 15\%; a cobertura de partos realizados em instituições de saúde, em cerca de 14\%; o número de consultas teve uma ampliação de mais de $30 \%$ no período de 1987/96; a mortalidade infantil caiu de 57/1.000 em 1987 para 33,7/1.000 dez anos depois; a mortalidade materna reduziu-se em 30\% no mesmo período; a redução de óbitos por causas mal definidas (indicador de falta de acesso a serviços de saúde) caiu de 12\% em 1987 para $8 \%$ em 1995. Em geral, análises mostram não apenas sensíveis avanços na ampliação da cobertura, mas melhoria da oferta e na qualidade dos serviços, particularmente na atenção primária; desenvolvimento de novas práticas gerenciais; organização de sistema de controle e avaliação mais eficientes (Fundação João Pinheiro, 1997). 
Com base em um diagnóstico da crise centrado no financiamento, na segunda metade da década de 90 as evidências e as críticas sobre insuficiência e irregularidade dos recursos destinados ao SUS ganham maior visibilidade, e propostas alternativas entram na agenda pública. Sob forte pressão do ministro da Saúde Adib Jatene para a criação de uma fonte adicional de recursos para financiamento do SUS, que redundou em sua demissão por incompatibilização com a área econômica do governo, e contando com fortes resistências tanto no Congresso quanto nos diferentes segmentos sociais a serem afetados, foi instituída, em 1996, a Contribuição Provisória sobre Movimentação Financeira (CPMF). Para isso ser possível, foi necessário alterar a Constituição, o que foi feito mediante a Emenda Constitucional 12, de agosto de $1996 .{ }^{163}$ Sua aprovação se deu sem mobilização social ampla. Ao contrário, grupos de pressão ligados ao empresariado, à mídia e outros se posicionaram em contrário com vigor (Goulart, 1998). A oposição era bastante previsível, uma vez que, ao ser uma nova tributação a incidir sobre as movimentações bancárias, viria atingir exatamente os setores que, na sua maioria, não se constituíam em usuários do SUS. ${ }^{164}$

Entretanto, a nova fonte, que deveria se constituir em um recurso supletivo, tornou-se substitutivo, na medida em que passaram a ser desviados recursos de outras fontes do orçamento da Seguridade Social, que em grande parte se destinavam ao setor saúde, como a Contribuição para o Financiamento à Seguridade Social (Cofins) e a Contribuição Social sobre o Lucro de Pessoas Jurídicas. ${ }^{165}$

163 A EC 12 incluiu nas Disposições Transitórias da Constituição de 1998 o artigo 74, pelo qual foi dada competência à União para instituir contribuição provisória sobre movimentação ou transmissão de valores e de créditos de natureza financeira. De acordo com essa emenda, alterada posteriormente, a receita proveniente dessa arrecadação deveria ser destinada integralmente ao financiamento das ações e serviços de saúde.

164 A estimativa é de que a CPMF atinge aproximadamente $18 \%$ da população, apenas a que mantém contas na rede bancária nacional.

165 Em 1996, a execução orçamentária do Ministério da Saúde foi de R\$ 14,4 bilhões, sem CPMF. Para 1997, esse orçamento passou a ser de R $\$ 20,5$ bilhões, com uma estimativa de arrecadação inicial de aproximadamente R\$ 5,3 bilhões da CPMF. Todavia, a arrecadação da CPMF no ano de 1997 foi de $\mathrm{R} \$ 6,7$ bilhões, valor $\mathrm{R} \$ 1,4$ bilhão superior ao inicialmente previsto. Soma-se a este fato o contingenciamento de $\mathrm{R} \$ 1,7$ bilhão no orçamento do Ministério da Saúde, que executou apenas $\mathrm{R} \$ 18,8$ bilhões em 1997. Isso significa que em 1997 a saúde teve $\mathrm{R} \$ 3,1$ bilhões a menos, sendo $\mathrm{R}$ \$ 1,4 bilhão de excesso de arrecadação da CPMF e R \$ 1,7 bilhão de corte no orçamento aprovado no Congresso Nacional (Fundação João Pinheiro, 1999). 
A ausência de fluxos regulares de recursos para a saúde gerou um movimento nacional, conhecido como 'Movimento SOS SUS', liderado pela Plenária Nacional de Saúde, em torno da vinculação de recursos para o setor que não fora estabelecida na Constituição, embora fosse uma proposta do movimento sanitário. Inicialmente contando com a resistência da área econômica do governo, a proposta só veio a se constituir em norma legal com a aprovação da Emenda Constitucional 29/2000, que garante recursos mínimos para o financiamento do SUS na forma de vinculação de recursos orçamentários dos diversos níveis de governo. Embora as primeiras Propostas de Emendas Constitucionais (PECs) no sentido de assegurar a destinação de recursos estáveis ao SUS datem de 1993, a discussão só foi acelerada no Congresso a partir de 1998, após obter o apoio explícito do presidente da República e por pressão do então ministro da Saúde José Serra, oriundo da área econômica e pertencente ao partido do presidente, que exerceu o papel de policy advocate da Emenda.

Todas as PECs tinham em comum o fato de vincular percentuais das receitas governamentais dos três níveis de governo ou do Orçamento da Seguridade Social para o sistema de saúde, e por essa razão recebiam o veto da área econômica do governo. A PEC 169/93, encabeçada por representantes do Partido dos Trabalhadores, então o maior partido de oposição, tornouse um símbolo do movimento desencadeado para a obtenção de recursos para o financiamento do SUS. Essa mobilização envolveu principalmente os gestores municipais e estaduais, incluindo os conselhos de Saúde dos três níveis de governo e os conselhos de secretários de saúde, os órgãos representativos de prestadores de serviços e de profissionais de saúde e outras entidades, como a Conferência Nacional dos Bispos do Brasil (CNBB) e o Fórum de Trabalhadores. ${ }^{166}$ No Congresso, contou-se com o apoio da Frente Parlamentar de Saúde, de caráter informal e multipartidária, mas com a participação de

\footnotetext{
166 Outro desdobramento do Movimento SOS SUS foram as denúncias feitas por um grupo de médicos em Belo Horizonte. Segundo essas denúncias, estaria sendo realizada a 'roleta-russa' no atendimento médico de urgência dos hospitais públicos: por falta de vagas nas unidades de terapia intensiva, os médicos tinham que 'escolher' entre quem deveria viver ou quem deveria morrer. Essa situação se explicaria pelo fato de $85 \%$ dos leitos hospitalares estarem destinados à ocupação por pacientes particulares ou convênios e apenas $15 \%$ aos pacientes do SUS (SindmedMG, 2000). De grande repercussão na imprensa, essas denúncias chamaram a atenção sobre a precariedade do SUS.
} 
vários deputados; o assunto também foi discutido na Comissão de Seguridade Social, à qual formalmente competem os assuntos relativos à saúde. A ampliação de recursos para o financiamento do SUS conseguiu aglutinar todos esses atores que, direta ou indiretamente, seriam beneficiados por ela, embora por diferentes razões: os gestores, por estarem premidos pela demanda de serviços e escassez de recursos; e os prestadores de serviço, insatisfeitos com a remuneração de seus serviços pelo Poder Público, vendo nessa PEC uma possibilidade de aumentar seus rendimentos pela garantia de maior estabilidade no financiamento da saúde. ${ }^{167}$

Com a pressão do chefe do Executivo, na ocasião muito criticado por ter negligenciado as questões sociais, e sob a condução do presidente da Câmara, foi realizado um acordo suprapartidário para aprovar em tramitação acelerada, tal como queria o ministro da Saúde, e com modificações feitas em consenso entre lideranças partidárias e governo, a PEC 82/95, do deputado Carlos Mosconi, do partido governista, que substituiu a PEC 169. Apesar da existência de divergências entre ministros e forte resistência de governadores, por significar a vinculação de recursos em um quadro de difícil situação financeira dos estados, a PEC foi aprovada, na forma de uma emenda aglutinativa, com encaminhamento unânime de todos os partidos. ${ }^{168} \mathrm{Na}$ fase de tramitação no Senado, manteve-se a grande mobilização pela aprovação da emenda, com a

\footnotetext{
${ }_{167}$ Depoimento colhido em entrevista com Rafael Guerra, médico, deputado federal pelo PSDBMG e integrante da Frente Parlamentar da Saúde, realizada em maio de 2002, é expressivo do processo: "Fomos ao presidente do Congresso, ao presidente da Câmara, ao ministro da Saúde, ao ministro do Planejamento, ao secretário da Casa Civil, ao secretário-geral da Presidência, ao José Serra (...) e a movimentação foi se ampliando, com a participação da Pastoral da Igreja, da Associação Médica Brasileira, Conselho Federal de Medicina e os outros Conselhos de Especialidades, o Conass [Conselho dos Secretários Estaduais de Saúde], o Conasems [Conselho Nacional de Secretários Estaduais de Saúde]. Houve audiências públicas, passeatas, reuniões com bancadas dos partidos (...). Isso durou quase um ano. Ao final, depois de todas as resistências do Ministério da Fazenda e do Ministério do Planejamento - que eram contra as vinculações orçamentárias, por engessar o orçamento e impedir o ministro do Planejamento de tomar decisões sobre as prioridades do governo -, depois de vencer todos os problemas, de discutir exaustivamente o assunto, o presidente da República apoiou a votação da emenda constitucional, com a condição de que ela implicasse também o financiamento pelos estados e municípios."

168 No debate parlamentar, houve consenso de que deveria ser vinculado um percentual dos impostos de estados e municípios. Mas a polêmica era relativa ao percentual adequado a ser destinado à saúde sem comprometer os seus orçamentos, forçar aumentos de impostos municipais e, principalmente, gerar a insatisfação dos prefeitos. Para contornar a questão, a EC 29 previu a progressividade do Imposto Predial e Territorial Urbano (IPTU) em razão do valor, localização e uso do imóvel, a qual, embora já fosse aplicada por várias prefeituras, estava sendo contestada juridicamente em sua constitucionalidade.
} 
participação do próprio ministro da Saúde, demonstrando seu apoio para uma alteração constitucional de forte apelo popular. ${ }^{169}$

A forma de aprovação dessa EC confirma análises sobre os mecanismos que regem as relações entre Executivo e Legislativo e seus efeitos na formulação de políticas públicas (Figueiredo \& Limongi, 1999; Pereira \& Mueller, 2000; Almeida \& Moya, 1997). O fato de a Constituição brasileira garantir amplos poderes legislativos ao Poder Executivo, ${ }^{170}$ aliado à forma de organização interna do Congresso Nacional, tem efeitos no funcionamento do sistema decisório e tem garantido ao Executivo bastante sucesso na aprovação de sua agenda legislativa. As instituições políticas brasileiras garantem o controle do Executivo sobre a iniciativa legislativa e cria incentivos para que os parlamentares apóiem sua agenda, na medida em que o Executivo controla recursos dos quais os congressistas dependem, o que os incentiva à cooperação. Os estudos sistemáticos realizados por Figueiredo e Limongi têm mostrado que o Congresso brasileiro não se constitui como uma instância institucional de veto à agenda do Executivo, que na maioria das vezes é quem define a agenda do Congresso, tanto no seu aspecto substantivo quanto no ritmo de tramitação

169 Para ilustrar o conflito para aprovação da PEC da Saúde, é elucidativo trecho de texto publicado no jornal da FBH (ano 1, n⿳ 9, maio de 2000): "A proposta [de Emenda Constitucional] enfrenta um verdadeiro fogo cruzado de interesses políticos, que dificulta sua tramitação no Congresso Nacional. O projeto já foi aprovado na Câmara e teve o sinal verde da Comissão de Constituição e Justiça do Senado. Porém, corre o sério risco de não ser votada em plenário neste semestre nem no próximo. Motivo: o senador Antônio Carlos Magalhães (PFL-BA) promete fazer de tudo para atrasar a votação. (...) os ministros da Saúde, José Serra, e da Fazenda, Pedro Malan, que disputam a preferência do presidente Fernando Henrique Cardoso na sucessão presidencial, são alguns dos principais protagonistas nessa guerra de interesses. Velhos inimigos políticos, Serra e ACM também se colocam em posições divergentes em relação à vinculação de recursos. Serra defende a proposta para aumentar as verbas para sua pasta e o Senador baiano bate o pé e afirma que vai atrapalhar o processo. Ocorre que como presidente do Senado, ACM é quem dá as cartas e tem poderes para fixar o dia da votação. Dessa forma, ele pode pôr na pauta de discussões quando bem entender. De olho nos possíveis dividendos políticos que a polêmica pode lhe render, o senador Jarbas Barbalho (PMDB-PA) anuncia: 'Vamos lutar pela aprovação da PEC'. ...monetarista e avesso a elevação de despesas, o ministro Malan é contra o projeto defendido por Serra. O presidente Fernando Henrique Cardoso, criticado por não priorizar a área social, se coloca favorável à vinculação de recursos para a saúde. Cauteloso, quer evitar desgastes para seu governo nessa disputa (...)".

${ }^{170}$ O poder legislativo do presidente está garantido na Constituição de 1988 por meio de vários dispositivos: a capacidade de legislar por medidas provisórias sem aprovação prévia no Congresso, que, conseqüentemente, tem grande influência sobre a agenda do próprio Congresso, dado o ônus de rejeitá-las após terem entrado em vigor; o poder de veto total ou parcial sobre projetos já aprovados no Congresso; e o poder exclusivo de iniciar legislação sobre problemas orçamentários e de administração pública. O Executivo dispõe também de um instrumento importante para interferir na tramitação de uma proposta, que é o pedido de urgência para seus projetos, largamente utilizado como mostram diferentes estudos. 
das questões, e após a Constituição de 1988 se constituiu no principal legislador de fato. ${ }^{171}$

Embora a EC 29 não tenha sido proposta diretamente pelo Executivo, este não deixou de definir a agenda tanto no conteúdo substantivo quanto no ritmo de sua aprovação, e só quando se empenhou diretamente é que a tramitação foi acelerada. A emenda sofreu as alterações propostas pelo Executivo, que também costurou um acordo suprapartidário para sua aprovação. Formalmente, não foi possível a utilização do instrumento do pedido de urgência, mas na prática o governo definiu quando e o que deveria ser aprovado, conseguindo definir uma descentralização dos encargos financeiros com saúde e preservar a União de uma vinculação mais explícita de recursos para a saúde. Substantivamente, apenas para os estados, municípios e Distrito Federal foi estabelecida uma vinculação de recursos orçamentários, mediante a destinação de um percentual progressivo dos seus orçamentos para o custeio das ações de saúde. Para a União, a EC 29/2000 definiu provisoriamente uma ampliação percentual dos gastos absolutos efetuados pela União no ano anterior e remeteu para uma lei complementar a definição dos percentuais mínimos a serem alocados na saúde. ${ }^{172}$ Ao ser adiada a solução da questão, a definição dos encargos federais com saúde foi deixada ao sabor da conjuntura política, mantendo-se, em certa medida, a vulnerabilidade do orçamento da saúde, na medida em que os recursos federais ainda são majoritários para o custeio das ações de saúde.

\footnotetext{
171 Analisando a produção legislativa no período de 1989 a 1998, Figueiredo e Limongi (1999) constataram que o Executivo, além de ser o autor da grande maioria das leis promulgadas, raramente teve suas proposições legislativas rejeitadas pelo Congresso.

172 A definição das receitas federais sobre as quais se definiria a vinculação para a saúde foi bastante polêmica na Câmara, e a discussão se polarizou: de um lado, a vinculação de um percentual de todo o orçamento da Seguridade Social; de outro, apenas de alguns de seus componentes - a chamada especialização de fontes -, especificamente a Contribuição Social sobre o Lucro Líquido (CSLL) e a Contribuição para o Financiamento à Seguridade Social (Cofins). A questão acabou sendo remetida para lei complementar. Até a aprovação de lei complementar, o artigo $7^{\circ}$ da EC 29 estabelece que no ano de 2000 o recurso mínimo a ser aplicado pela União será “o montante empenhado em ações e serviços públicos de saúde no exercício financeiro de 1999 acrescido de, no mínimo, cinco por cento"; e "do ano de 2001 ao ano 2004, o valor apurado no ano anterior, corrigido pela variação nominal do Produto Interno Bruto - PIB”. Para estados e municípios define $12 \%$ e $15 \%$, respectivamente, de sua receita de impostos e de transferências recebidas, deduzindo-se no caso dos estados as transferências realizadas para os municípios, valores a serem alcançados progressivamente até o ano de 2004. O gradualismo evita pressões iniciais sobre as finanças dos estados e municípios, permitindo-lhes um ajustamento gradativo.
} 
A mudança de postura do Executivo federal, ao passar a defender a aprovação da vinculação de recursos para a saúde, não indica uma intenção de ampliar os gastos federais para o custeio do sistema de saúde. Ao contrário, evidencia, em primeiro lugar, o propósito de deslocar a questão do financiamento da saúde prioritariamente do nível federal para as instâncias subnacionais de governo, forçando-as a ampliar sua participação no gasto em saúde; e, em segundo lugar, a intenção de desvincular da saúde os recursos da CPMF, o que exigiria como contrapartida o estabelecimento de nova fonte de custeio para o setor. A tentativa de tramitação acelerada da EC coincide com a aproximação do término da vigência da CPMF, aprovada inicialmente com a proposta de ser provisória e destinada para a saúde, mas que, de fato, tornara-se uma importante fonte de receitas para o governo federal. Prorrogada, por meio da EC 21/1999, os recursos decorrentes da arrecadação da CPMF passaram a ser direcionados para o custeio da Previdência Social, deixando legalmente de ter a destinação exclusiva para a saúde, que justificara sua criação. ${ }^{173}$ Essa mudança foi mais um veto implícito ao setor saúde, ao mesmo tempo que, por meio de um jogo de contradições, defendia-se e conseguia-se, aparentemente, a aprovação de mais recursos para a saúde.

A desconfiança sobre a intenção do governo de solucionar o problema de financiamento do SUS foi expressa por parte dos parlamentares oposicionistas e até da base governista durante a tramitação da 'PEC Saúde'. Essa desconfiança se baseava em um conjunto de ações em sentido contrário, como os constantes contingenciamentos do orçamento da saúde, a utilização dos recursos arrecadados com a CPMF fora do setor saúde e a retenção de recur-

\footnotetext{
173 As intenções do governo federal transparecem em depoimento do ministro da Saúde em audiência pública realizada em maio de 1998, durante os trabalhos da Comissão Especial constituída para proferir parecer à PEC 29, conforme estabelece a legislação, realizada antes da alteração da CPMF: "Durante a constituinte foram aprovadas mudanças no Sistema Tributário, que aumentaram muito as receitas estaduais e municipais, não a federal. (...) Mas verificamos que, independentemente de casos isolados, em regiões ou exemplos que aqui possam ser encontrados, na média, as despesas com a saúde encolheram nos Estados, e as dos Municípios não aumentaram. Então eu concluí, ao longo desses anos, que, além da necessidade de um mínimo Nacional [para financiamento do SUS], seria muito importante um mínimo federal para que tivéssemos proporções entre União, Estados e Municípios. (...) A CPMF não é uma receita específica da saúde. Aliás, o Congresso Nacional não a aprovou como tal. O Congresso aprovou uma receita da Seguridade Social. Portanto, a CPMF, hoje, está financiando déficit da Previdência." Há que se destacar que diferentes estudos mostram que a diminuição de recursos foi verdadeira para os estados, mas não para os municípios, que, em geral, aumentaram seus gastos com saúde após a descentralização, o que os colocou sob forte demanda dos munícipes.
} 
sos da seguridade social para o Fundo de Estabilização Fiscal. Além disso, outras decisões governamentais não sugeriam uma postura de fortalecimento do setor público, como a regulamentação dos planos e seguros de saúde, concomitantemente à discussão da vinculação de recursos para o financiamento do SUS, que mostrou o interesse de alavancar o crescimento do mercado privado de assistência à saúde; a abertura de hospitais públicos, particularmente os universitários, para clientelas privadas via convênios como forma de arrecadar recursos adicionais e que tinha como conseqüência a restrição de vagas para pacientes do SUS; e a proposta de transformar os hospitais públicos em organizações sociais juridicamente privadas, com vistas a tornálos mais eficientes e auto-sustentáveis. ${ }^{174}$

A forma de cumprimento da EC 29 sugere a falta de empenho governamental para solucionar o problema do subfinanciamento do SUS. A implementação da emenda que vincula recursos dos três níveis de governo para o financiamento de ações e serviços públicos de saúde estava longe de se tornar uma realidade, e não parece que seria de fato uma solução. A forma de frear o aumento de recursos da União para o sistema de saúde público se deu mediante um conflito intraburocrático de diferentes interpretações da legislação que se verificou nos dois primeiros anos após a aprovação da EC 29. Se no caso da vinculação dos recursos estaduais e municipais a legislação é autoaplicável, para os recursos da União para os exercícios de 2001/2004, período de transição até a definição de lei complementar, a implementação foi polêmica. Embora o texto legal à primeira vista não sugerisse dúvidas sobre a forma de cálculo dos recursos mínimos a serem aplicados pela União, houve um choque entre duas interpretações jurídicas. Por um lado, coincidem as interpre-

\footnotetext{
74 Essa desconfiança não se manifestava apenas entre a oposição, mas também na base parlamentar governista, como mostra o pronunciamento do deputado Arnaldo Faria de Sá (PPB-SP) no Congresso Nacional em maio de 2000, um dos poucos que votaram contra a Emenda: "A própria votação em primeiro turno já demonstrou a vontade da maioria deste Plenário de aprovar esta PEC, tentando salvar a saúde. Digo ‘tentando' salvar a saúde - mais uma vez -, porque já aprovamos a CPMF, que tinha o mesmo objetivo. Depois, tornamos definitiva a contribuição que era provisória; e ainda aumentamos o seu percentual em 90\%, passando de 0,20 para 0,38\%. Na verdade, nada resolveu o problema da saúde, e continuou havendo desvio na arrecadação dessas verbas, justamente para que tivéssemos de buscar outras alternativas. Esta também não será a solução. Vincular-se-ão orçamentos federais, estaduais e municipais, e continuaremos tendo uma saúde caótica. (...) Na prorrogação da CPMF, a área econômica, que era contra a criação da contribuição, passou a ser a favor, por entender que os recursos eram necessários para a saúde financeira, e não para a saúde das pessoas" (Câmara dos Deputados/Detaq, 8/5/2001).
} 
tações da Procuradoria Geral da Fazenda Nacional/Ministério da Fazenda, apoiada por parecer da Advocacia Geral da União; por outro, as da Consultoria Jurídica e da Subsecretaria de Planejamento e Orçamento do Ministério da Saúde, do Conselho Nacional de Saúde e do Tribunal de Contas da União, defendida pela chamada 'Bancada da Saúde' no Congresso Nacional. A controvérsia centra-se principalmente na base de cálculo a ser utilizada para os valores sobre os quais a União deverá aplicar os aumentos anuais dos recursos empregados na saúde. ${ }^{175}$ De acordo com a primeira interpretação, conhecida como 'base fixa', na fase de transição da EC 29 o cálculo dos recursos teria como base o valor apurado em 2001, acrescido, ano a ano, pela variação do PIB sobre essa mesma base. A segunda interpretação, originária dos setores ligados à saúde mas endossada por parecer do Tribunal de Contas da União, como era de se esperar, favorece a ampliação de recursos, ao contrário da interpretação do setor econômico do governo. Isso porque considera que a apuração deve ser feita ano a ano, com uma base de cálculo móvel. ${ }^{176}$

A divergência intraburocrática relativa à interpretação da forma de aplicação da emenda constitucional na definição concreta dos montantes a serem alocados pelo governo federal mostra a inexistência de um projeto global de governo para a concretização do SUS, explicitada pela divergência entre as agências encarregadas da política econômica e da saúde. Na prática, o governo tem adotado como referência para a fixação dos tetos orçamentários para o setor saúde a interpretação da Procuradoria Geral da Fazenda Nacional e da

\footnotetext{
75 Outras controvérsias referem-se ao entendimento do que sejam ações e serviços de saúde que delimitam o universo dos gastos previstos pela EC 29 e sobre a correção de valores pela variação nominal do PIB. As diferentes interpretações geram conseqüências para a definição do montante a ser aplicado pela União no setor saúde. Com base nos entendimentos mais comuns sobre três variáveis - ou seja: 1) o que seja 'valor apurado no ano anterior', e daí a definição da base de cálculo; 2) a forma de consideração da correção do PIB; e 3) a definição das ações e serviços de saúde - são possíveis 12 combinações que, conseqüentemente, levam a valores diferentes.

176 Trecho do parecer do TCU é elucidativo dos objetivos visados com a EC 29: "Isso significa que a partir de 2001 e até os anos de 2004, a cada ano deverá ser apurado o montante empenhado em ações e serviços públicos de saúde no ano anterior. Sobre esse valor deve ser aplicado um multiplicador correspondente à variação nominal do Produto Interno Bruto - PIB - no mesmo período" (voto do ministro-relator acolhendo proposta formulada pela unidade técnica e endossada pelo Ministério Público - TCU, 6/3/2002).
} 
Advocacia Geral da União, decisão que se traduz em prejuízos para o setor. ${ }^{177}$ A transferência de parte da responsabilidade do custeio da saúde para as instâncias subnacionais de governo vem ocorrendo de forma acentuada para os municípios. No conjunto, em 2000 os municípios já superavam a meta prevista de gasto mínimo de $7 \%$ da receita própria em ações de saúde. ${ }^{178}$ Há indícios de que grande parte dos estados não está sendo capaz de cumprir as determinações da emenda, em razão da falta de disponibilidade de recursos em uma conjuntura caracterizada pelo endividamento e pelo alto comprometimento das suas receitas, particularmente com o pagamento dos encargos de pessoal ativo e inativo, e outras despesas vinculadas. ${ }^{179}$

Tudo indica que os aportes adicionais de recursos esperados a partir da EC 29 não têm sido significativos a ponto de reverter o quadro de subfinanciamento do SUS, particularmente para garantir recursos para investimentos - ponto frágil do sistema. Está também na dependência da lei com-

77 Para o ano de 2000, para o qual não há controvérsia sobre a base de cálculo do incremento de recursos da União, já não houve cumprimento da emenda, como mostra análise da Consultoria de Orçamento e Fiscalização Financeira do Núcleo de Saúde da Câmara dos Deputados (Estudo $\left.n^{\circ} 2,2000\right)$. Seja qual for a interpretação dada à expressão 'ações e serviços públicos de saúde', o orçamento da saúde esteve aquém do piso estabelecido para o setor em no mínimo R\$ 590 milhões se for considerado com aquela expressão apenas o programa de saúde do Ministério da Saúde, sendo excluídos os encargos previdenciários, os serviços da dívida e as ações de saneamento. Para 2001, a emenda estaria sendo cumprida, dependendo da forma de utilização da variação nominal do PIB: se utilizada a variação estimada do ano de 2001, o orçamento contemplava a mais a emenda; mas, na hipótese de utilização da variação estimada do PIB de 2000, haveria déficit no montante a ser alocado para a saúde, dependendo da conceituação da expressão 'ações e serviços públicos de saúde' (Consultoria de Orçamento e Fiscalização Financeira do Núcleo de Saúde da Câmara dos Deputados - Estudo n 2, 2000). Mesmo considerando a menor variação do PIB, a adoção da interpretação da base fixa para o cálculo do montante de recursos a ser alocado pela União se traduziu em diferenças acentuadas no orçamento do Ministério da Saúde em 2001, resultando em uma perda de R\$1.199.620.205,00 em comparação ao que deveria ser alocado caso se optasse pela interpretação da base móvel (ano anterior) sobre a qual deveria incidir a correção pela variação do PIB (Ministério da Saúde, 2001).

${ }^{178}$ No caso dos municípios, de acordo com os últimos dados do Sistema de Informações sobre Orçamentos Públicos em Saúde (Siops), que padroniza informações de receitas e gastos em saúde das três esferas de governo, o percentual da receita própria aplicada em saúde já em 2000 superava a meta prevista, que seria de um gasto no mínimo de $7 \%$, devendo alcançar progressivamente $15 \%$ até 2004. A média do país já estava em torno de 13\% em 2000, sendo que o percentual mais baixo se verificou na região Nordeste (cerca de $9 \%$ ).

179 De acordo com estudo do Ministério da Saúde (2001), quatro estados já aplicavam em 1998 percentuais de sua receita na saúde superiores a $12 \%$ - teto previsto na EC 29; 13 estados aplicavam percentuais situados entre o piso e o teto - entre $7 \%$ e $12 \%$. Entretanto, editorial do jornal Folha de S.Paulo (15/3/2003: 2) criticou a manipulação de gastos utilizada por vários estados, computando como de saúde gastos que não se enquadram nessa rubrica, e divulgou: "levantamento do Ministério da Saúde mostra que, em 2001, descontadas as despesas que não deveriam ser consideradas gastos em saúde, 17 das 27 unidades da Federação descumpriram a emenda 29 (...)". 
plementar a definição das formas de fiscalização, avaliação e controle das despesas com saúde nas esferas federal, estadual e municipal. Caso essas questões não sejam resolvidas, a EC 29 parece ser mais uma definição meramente formal para a viabilização dos princípios constitucionais relativos à saúde, persistindo a sua inviabilização sistêmica. Diante disso, após iniciativas do Conselho Nacional de Saúde, existe a ameaça de se retomar a mobilização social pelo SUS, que fora fundamental para a aprovação da emenda que vincula recursos orçamentários à saúde. ${ }^{180}$ Estudos, seminários e outros eventos têm sido realizados e contam com a participação da Frente Parlamentar de Saúde, dos conselhos representativos dos secretários de saúde, órgãos públicos e conselhos de saúde, além do próprio Ministério da Saúde, interessado em resolver os problemas históricos de financiamento do SUS. A campanha pela reformulação da interpretação adotada para cálculo dos recursos federais desencadeada em 2001 recebeu o nome de 'Erro que mata' e teve como norteadora a revisão da interpretação pela equipe econômica do governo, ante a possibilidade, inclusive, de diminuição dos recursos disponíveis.

A trajetória da EC 29 reafirma a idéia da fragilidade institucional brasileira, não em razão da inexistência de regras ou de leis, mas da ausência de cumprimento delas ou de sua instabilidade. A dependência de leis complementares que podem alterar o espírito do dispositivo constitucional, a possibilidade de revisão de valores prevista para acontecer a cada cinco anos, as diferentes interpretações de um texto legal aparentemente auto-aplicável, o não-cumprimento das normas legais e a defesa governamental de uma idéia que não se pretende afirmar concretamente são apenas algumas das manifestações do descompasso entre o formal e o real no processo político brasileiro.

180 Para discutir as questões que demandam regulamentação para melhor aplicabilidade das determinações constitucionais, foi formado um grupo de discussão técnica, com representantes do Ministério da Saúde, Ministério Público Federal, Conselho Nacional de Saúde, Conselho Nacional de Secretários Estaduais de Saúde (Conass), Conselho Nacional de Secretários Municipais de Saúde (Conasems), Comissões de Seguridade Social da Câmara e Assuntos Sociais do Senado e Associação dos Membros dos Tribunais de Contas (Atricon). 


\section{Síntese}

Neste capítulo, foi analisada a reforma da política de saúde, desdobrando-a em três processos que, embora tratados de forma seqüencial, em grande parte se sobrepõem e cujo resultado é a conformação da política de saúde atual: o processo de formação das propostas e de articulação política, que se inicia em meados da década de 70; o processo decisório nos anos 80, particularmente durante a Constituinte; e o processo de implementação da reforma, que se inicia na década de 90 , após a mudança constitucional. $\mathrm{Na}$ reconstrução do ciclo da reforma, foi possível identificar os efeitos das políticas anteriores sobre o processo político-decisório, em decorrência dos quais, mesmo em uma situação de rearranjos institucionais no âmbito da assistência pública, foram preservados os mecanismos privados de assistência à saúde, apesar de formalmente se confrontarem com princípios definidos na Constituição de 1988.

A principal conclusão desta análise é que a reforma da política de saúde, cuja expressão mais concreta é a criação do SUS, caracteriza uma situação de ruptura e continuidade, explicável em razão da confluência de fatores que favoreceram a inovação institucional com o legado das políticas de saúde prévias que limitaram a possibilidade de mudança. Tanto a inovação quanto a tendência à inércia institucional foram favorecidas por conjunturas políticoeconômicas mais amplas. A mudança foi possibilitada por uma situação excepcional de construção de um novo pacto social no processo de democratização, no bojo do qual se constituiu um novo marco legal para a saúde na década de 80. Por sua vez, a continuidade dos padrões assistenciais foi favorecida pelas orientações prescritivas que caracterizaram o período de implantação do SUS na década seguinte, as quais enfatizavam a focalização da atuação governamental nos setores de menor poder aquisitivo, deixando para o mercado a cobertura dos segmentos com capacidade de compra. Essa última conjuntura corroeu o ideário da reforma, antes mesmo que ele tivesse sido capaz de alterar a forma de atuação governamental construída historicamente. Como a segmentação de clientelas antecede a difusão dessas prescrições a partir dos anos 80, o formato da política de saúde definido após a reforma não é explicado pela conjuntura normativa de implantação do SUS, mas pela dependência 
de sua própria trajetória, que colocou limites para uma reforma mais ampla, levando a um processo de inovação limitada.

O principal fator que favoreceu a mudança da política de saúde foi a modificação da arena política setorial, com a incorporação de novos atores portadores de propostas alternativas, que se confrontaram com aqueles constituídos a partir das políticas anteriores. Essa ampliação foi favorecida, inicialmente, pela conjuntura de abertura política, ainda nos anos 70 , na qual a priorização da questão social como forma de legitimação do regime abriu brechas para uma atuação diferenciada no âmbito da própria instituição previdenciária, responsável pela política de assistência. No contexto de democratização, caracterizado pelo desenvolvimento de movimentos sociais variados, foi possível ampliar o escopo de atores em torno da reforma sanitária e da expansão dos direitos sociais. Esse conjunto de atores constituiu as demandas e o suporte político para as alterações na política. A crise assumida da assistência, que se traduzia em insatisfação generalizada, foi outro fator que favoreceu a mudança institucional, na medida em que o movimento sanitário soube apresentar uma alternativa para a crise, colocá-la na agenda e obter apoio político para ela.

A Constituição e o desenvolvimento do movimento sanitário e sua influência na conformação da política de saúde evidenciaram a importância das idéias no processo de formação de políticas. As idéias se relacionam com as preferências dos atores ao expressar suas respectivas imagens da realidade sobre a qual se pretende intervir, conformando as soluções e definindo suas propostas de ação. O movimento reformador surgiu de uma concepção teórica sobre a saúde coletiva, construída e desenvolvida no âmbito acadêmico, que ganhou espaço na burocracia pública e construiu aliados entre o movimento médico, o movimento popular e, nos anos 80, os gestores municipais. A elaboração de novos conceitos e propostas por parte dos precursores do movimento sanitário, ao coincidir com uma conjuntura política favorável e associada a estratégias de mobilização política ativa, favoreceu mudanças nos princípios e no desenho da política de saúde. Nesse processo de inovação na política, constituiu-se uma comunidade epistêmica, cuja influência se traduziu em alterações no processo político, por ter sido capaz de fazer a mediação entre a crise e as escolhas realizadas, ao fornecer uma proposta consistente e de 
amplo respaldo, que norteou a elaboração do capítulo sobre saúde na Constituição. No processo de ampliação dos apoiadores da reforma, ocorreu um estreitamento das idéias iniciais dos precursores do movimento sanitário, e de um projeto de transformação da sociedade e do Estado passou-se para uma proposta de reformulação da forma de intervenção governamental no campo da saúde. Ao mesmo tempo, algumas idéias foram bloqueadas, como a proposta de estatização completa do sistema de saúde, defendida na VIII Conferência Nacional de Saúde, em 1986.

$\mathrm{Na}$ transição democrática, abriu-se uma 'janela política', de forma que os problemas das políticas vigentes, associados ao processo político mais amplo de democratização, convergiram de modo a permitir que forças políticas nãohegemônicas influenciassem decisivamente a formulação da política de saúde, dando lugar, em um momento específico, ao surgimento de uma política informada por uma ideologia publicista e por uma concepção de saúde como direito, tendo como corolários a universalização e a igualdade. ${ }^{181}$

Por sua vez, o caráter limitado da reforma, na medida em que a mudança se realizou sem alterar o caráter dual da assistência, foi explicado pelos efeitos de feedback das políticas prévias sobre o processo político-decisório. Esses efeitos se expressam pela constituição de atores e interesses e, conseqüentemente, na conformação da arena política, em decorrência dos incentivos e decisões que foram responsáveis pela formação das preferências dos atores favorecidos pelas políticas de saúde estabelecidas a partir dos anos 60. Esses interesses ligados aos diversos agentes do mercado privado de saúde, como operadoras de planos de saúde, prestadores de serviços e usuários, apoiados por grande parte da burocracia previdenciária, manifestaram-se em todas as situações em que propostas ou medidas governamentais indicaram alterações no modelo assistencial no sentido de privilegiar o setor público. Particularmente durante o funcionamento da Assembléia Nacional Constituinte, quando o Congresso Nacional se transformou no principal locus decisório, o embate entre os defen-

\footnotetext{
181 A idéia de janela para políticas considera a perspectiva de Kingdon (1984, apud Gomà \& Subirats, 1998) relativa à elaboração de políticas, segundo a qual problemas, políticas e processo político convergem e divergem, dando lugar no momento e no lugar adequados ao surgimento de uma política concreta.
} 
sores das formas privadas de atenção à saúde e os defensores das propostas do movimento sanitário foi acirrado. Naquele momento, tanto os representantes do movimento reformador quanto os da assistência privada estavam suficientemente consolidados e organizados, e tiveram capacidade de influenciar o processo decisório.

O resultado foi a aprovação de um projeto transformador de grande alcance para a saúde, com traços redistributivos e com objetivos igualitários, significando, portanto, uma mudança institucional e de princípios, ao mesmo tempo que foi garantida a continuidade por meio de alguns dispositivos e, principalmente, daquilo que a Constituição não expressou. Ao limitar a reforma ao setor público e ao garantir a liberdade à iniciativa privada, interferindo apenas no setor privado quando prestando serviços sob a responsabilidade estatal, a Constituição consagrou a dualidade do sistema de atenção à saúde no Brasil, composto por um segmento público e outro privado, e a reforma da política de saúde perdeu muito de sua conotação transformadora. Em vez de possibilitar uma efetiva ruptura institucional, se justapôs às estruturas institucionais preexistentes, com pouca probabilidade de substituir o passado. Com a ausência de dispositivos constitucionais regulatórios do setor privado, garantida em razão do poder de veto dos representantes dos interesses do mercado de saúde, a legislação encobriu a segmentação, de forma que a universalização e a igualdade se transformaram em metaobjetivos sem correspondência na estrutura institucional. O caráter segmentado da assistência à saúde, que caracteriza a trajetória brasileira de expansão da assistência médica, formalizou-se assim nas próprias decisões consagradas na Constituição, aparentemente de forma paradoxal aos objetivos da reforma global pretendida pelos seus promotores. Esse foi o resultado do conflito das propostas reformadoras com os interesses consolidados em razão da configuração anterior das instituições de saúde, sendo provável que políticas alternativas que mudassem o padrão vigente não tivessem suporte político suficiente, mas poderosos vetos, de tal forma que o arranjo institucional consolidado na assistência à saúde limitou as escolhas possíveis. Em termos legais, a escolha resultante do embate entre alternativas distintas, que expressavam as preferências de dois conjuntos de atores, contemplou as duas propostas ou os dois ideários que se confrontaram durante o processo constituinte. 
Um segundo efeito de feedback das políticas anteriores pode ser observado no processo de implementação da reforma, o qual se traduziu na falta de suporte político efetivo de categorias sociais relevantes, seja por sua atuação no setor saúde, seja por sua maior capacidade de mobilização. O movimento sanitário não se constituiu como um grupo de interesse, embora agregasse alguns, mas como um conjunto de pessoas e instituições que, em alguma medida, em um momento singular de refundação democrática, partilharam um conjunto de valores éticos e propostas políticas e técnicas com o objetivo de democratização do sistema de saúde. Essa 'identidade’ foi forjada na conjuntura autoritária que permitiu a minimização dos interesses particularistas em prol de uma transformação política e ética mais geral. Mas mostrou sua fragilidade e descontinuidade no momento de implantação da reforma sanitária, no contexto pós-governo militar, quando as alianças mais amplas não lograram se sustentar.

Após a redemocratização, as diferentes clivagens se explicitaram em um processo de transição caracterizado pelo conservadorismo e pela manutenção no poder das mesmas lideranças do período autoritário. Nesse momento, não se conseguiu mais uma homogeneidade de propostas, tanto pelas fraturas ideológicas internas do movimento sanitário e do movimento popular quanto pela retomada das questões meramente corporativas de atores que se tinham aglutinado ao movimento, particularmente os profissionais médicos. Nesse último caso, incluíam-se também os trabalhadores e os sindicatos com maior nível de organização e maior poder de barganha, localizados nos grandes centros industriais no eixo Rio-São Paulo. Embora o apoio ao SUS tenha sido generalizado entre eles e se mantivesse formalmente no período de implementação, de fato não havia muitos incentivos para um apoio mais efetivo a uma reforma sanitária radical, entendida como uma transformação publicista da assistência à saúde. Pelo menos a curto prazo a implantação completa do SUS possivelmente lhes traria perdas objetivas, na medida em que, na sua maioria, eles deveriam estar vinculados a planos de saúde empresariais, a essa altura institucionalizados e em franca expansão desde a década de 80 , constituindo-se, muitas vezes, em objeto de negociação coletiva, 
mesmo que ideologicamente não deixassem de expressar apoio incondicional às propostas do Sistema Único de Saúde. ${ }^{182}$

Por sua vez, os prováveis usuários do SUS, os segmentos excluídos da assistência privada - seja pela menor renda, seja pela forma de inserção mais precária no mercado de trabalho -, não demonstraram capacidade de mobilização que pudesse dar sustentação à reforma, que, por suas características redistributivas, demandaria coalizões mais amplas, particularmente em uma situação institucionalizada de diferenciações e privilégios. Nem os movimentos populares mantiveram uma mobilização coesa nem os sindicatos mais fortes se mobilizaram de fato (e não apenas formalmente) por uma assistência universal, igualitária e pública, ao mesmo tempo que os profissionais de saúde retomaram o caráter exclusivamente corporativo de sua atuação política.

Essa falta de suporte refletiu a ausência de uma demanda universalista entre os trabalhadores e categorias profissionais que traduzisse a existência de uma identidade coletiva e o desenvolvimento de valores solidaristas que pudessem se expressar no apoio efetivo à proposta do SUS. Nada disso foi favorecido pela trajetória de expansão dos direitos sociais no país, entre eles a assistência à saúde, que, ao contrário, deu-se com base em um modelo meritocrático, desenvolveu-se favorecendo as demandas corporativas no âmbito das instituições previdenciárias e, após o surgimento e o desenvolvimento da assistência empresarial, tornou-se um benefício particularizado, dependendo

\footnotetext{
182 Alguns analistas do movimento sanitário, que dele faziam parte dado o caráter de saber militante que caracteriza o setor saúde, atribuem à opção institucional do movimento sanitário o fracasso parcial da reforma sanitária após ter ganho o estatuto constitucional. Ao privilegiar as instituições, o movimento sanitário relegou a segundo plano a ampliação e o aprofundamento de alianças com as classes populares e trabalhadoras, em princípio, as principais beneficiárias da reforma (Escorel, 1998). Ao se tentar impor reformas por intermédio do aparelho estatal, tendo como principais interlocutores ocupantes de cargos no Executivo e nos partidos dominantes, sem compor com o movimento sindical e com os partidos apoiados neles, não se constituiu uma base social de sustentação da reforma sanitária, o que enfraqueceu a implantação de uma agenda radicalmente transformadora (Campos, 1988). Ou, de acordo com Mendes (1993: 39), não se conseguiu acumular na sociedade "capital político" para enfrentamento do projeto neoliberal hegemônico, com o qual o movimento sanitário se contrapunha. Implícita nessas explicações está a idéia de que se a opção principal do movimento sanitário tivesse sido a busca de alianças sociais que garantissem apoiadores para a reforma sanitária, sua implantação teria maiores perspectivas de sucesso. Algumas implicações decorrem daí: primeiro, que isso seria factível; segundo, que esses setores sociais estariam dispostos a apoiar a reforma, sendo que para isso teriam que identificar ganhos nela. Mas se admitimos que os trabalhadores mais organizados e com maior poder de barganha não tinham interesses objetivos no sucesso do SUS, na medida em que tinham garantidos planos de saúde empresariais, essa suposição não se sustenta. Por sua vez, se o projeto privatista era hegemônico, estava institucionalizado e tinha apoiadores fortes, seria pouco provável que os setores populares tivessem condições políticas de barrá-lo caso fossem mobilizados.
} 
da forma de inserção no mercado de trabalho. Como outro efeito de feedback das políticas prévias, os interesses mais imediatos dos trabalhadores não tinham muita afinidade com a proposta igualitária e redistributiva do SUS. Nessa perspectiva, seriam longínquas as possibilidades de alcançar a universalização partindo de um modelo de cidadania regulada, definida com base na inserção diferenciada no mercado de trabalho.

O veto implícito à implantação da reforma em sua completa acepção não veio, contudo, apenas dos segmentos favorecidos pela assistência privada. Por meio de mecanismos indiretos, particularmente o subfinanciamento do SUS, o próprio governo não garantiu a viabilização dos objetivos da reforma. A indefinição e a ausência de fontes estáveis de financiamento têm barrado os avanços da implantação do sistema público. A aprovação da EC 29/2000, que teoricamente vincula recursos dos três níveis de governo para a saúde, não demonstra que a questão terá uma solução satisfatória. Como a principal fonte de recursos para custeio da assistência pública é de origem federal, as divergências relativas à base de cálculo para a definição da contribuição da União têm se traduzido em alocação de recursos aquém do esperado com a aprovação da EC, com possibilidades de redução a médio prazo. A transferência dos encargos financeiros para as unidades subnacionais de governo sugere o menor comprometimento do governo federal com o financiamento do SUS, caracterizando um processo de inviabilização sistêmica, mesmo que não se manifestem propostas explícitas de redução programática do escopo do SUS.

A conjuntura econômico-financeira não foi favorável à implantação do SUS, que, para sua efetivação, necessitaria de uma ampliação de recursos proporcional à expansão da clientela e das atribuições, o que não foi favorecido pela situação de recessão econômica. Entretanto, isso não significa que o problema seja apenas a falta da capacidade de implementação, particularmente financeira, pois pressupõe-se que existiria, de fato, o objetivo estatal de implantação dos dispositivos constitucionais, ou seja, um sistema público de caráter universal e igualitário. Ao que tudo indica, um projeto publicista para a saúde não se constituiu como um objetivo governamental. Os princípios do SUS conseguiram ser definidos como política de governo em razão de uma conjuntura privilegiada, caracterizada pela redemocratização, mas sua implantação vai se dar em um quadro político dominado por forças políticas 
conservadoras e na contramão das propostas conhecidas como neoliberais, fortalecidas em contexto marcado pela perda de apoio e legitimidade de políticas sociais universalistas e pela valorização das opções de políticas com a valorização do mercado, em detrimento de opções caracterizadas pela ampliação da esfera de atuação do Poder Público. Nesse contexto, a tradução concreta das normas legais não foi acompanhada de um projeto efetivo de redução das desigualdades sociais nem foi determinada por um processo de reforma global do Estado nesse sentido.

No momento de implantação da reforma, não apenas as contradições da legislação se evidenciam, mas também se fecha a janela anterior, e outros fatores vão convergir de forma a não tornar realidade a assistência à saúde universal e igualitária.

Entretanto, esses processos de ruptura e continuidade convivem durante todo o período de três décadas no qual se desenvolve o processo da reforma, caracterizado por movimentos contrários e paralelos, sendo que ao mesmo tempo que se consolidam tendências definidas em razão das escolhas políticas anteriores, ocorrem mudanças institucionais. Se as primeiras favorecem o desenvolvimento da assistência privada, as mudanças são no sentido de fortalecimento das ações e concepções públicas. O resultado foi a conformação jurídico-legal de um sistema de saúde híbrido e segmentado que, ao passo que consagra a saúde como direito e garante a universalidade de acesso à assistência à saúde, preserva a liberdade do mercado de assistência privada, indicando o aprofundamento da diferenciação entre clientelas em razão da forma de cobertura assistencial.

Esses movimentos duplos se evidenciam desde a década de 70, período de consolidação do modelo 'médico-assistencial privatista', estruturado principalmente a partir dos anos 60, como conseqüência da opção governamental de expansão de cobertura pela via da compra de serviços privados em detrimento da ampliação da rede prestadora pública. O período é também de desenvolvimento das iniciativas empresariais privadas, voltadas para a assistência dos empregados das grandes empresas públicas e privadas, incentivadas pelo governo por meio da alocação direta de recursos. Concomitantemente, inicia-se uma articulação político-ideológica por reformas na política, no sentido das propostas construídas a partir do movimento sanitário como decorrência da crítica ao 
modelo vigente e que vão encontrar condições favoráveis para sua viabilização com o aprofundamento da crise financeira decorrente do próprio modelo assistencial e no bojo do processo de transição democrática. Se o primeiro movimento refletia a visão predominante na burocracia previdenciária, em grande parte dominada pelos interesses empresariais na área da saúde, o segundo foi centrado na crítica ao financiamento do setor privado pelo setor público e construído com base em uma concepção publicista da atenção à saúde.

Já nos anos 80, ao mesmo tempo que se adensa o movimento pela reforma sanitária com o objetivo principal de garantir a universalização e a gratuidade do acesso à assistência à saúde, ocorre a expansão acentuada da assistência privada de forma autônoma, embora influenciada por uma série de decisões governamentais e por incentivos indiretos, capazes de conformar as decisões de atores privados, como usuários, prestadores de serviços e operadoras de planos privados. Essa expansão das formas privadas de assistência ocorre tanto dentro como fora das grandes empresas empregadoras, por meio da captação de clientes individuais pelas diversas modalidades de operadoras que comercializam planos de saúde. Correlatamente, o setor privado prestador de serviços vai deixando de ser dependente do financiamento público e passa a adquirir um novo mercado nos planos de saúde empresariais e individuais em expansão.

As decisões relativas à política de saúde no período refletem esses duplos movimentos. Se algumas favoreceram a assistência privada, a penetração das idéias e de participantes do movimento sanitário nas instituições responsáveis pelas políticas de saúde se traduziu em propostas e na efetivação de algumas políticas voltadas para o fortalecimento do setor público e para a universalização da cobertura, que podem ser vistas como precursoras da reforma definida na Constituição. Embora essas experiências não tenham logrado alterar o padrão assistencial fortemente institucionalizado, o conflito entre as propostas inovadoras e os interesses privados consolidados em razão das políticas anteriores se verificou em todas as ocasiões em que foram ensaiadas políticas que privilegiassem o setor público em detrimento do privado e que se diferenciavam do modelo de assistência prevalecente. Ao mesmo tempo, foram criadas novas instituições, como as AIS e o Suds, que passaram a funcionar como filtros das idéias da reforma. 
Os movimentos contraditórios se expressaram na legislação e também no processo de implantação recente, pois, apesar das restrições, o SUS foi se institucionalizando, inclusive pelo reconhecimento público do direito à saúde. Nesse processo, outros atores se constituíram e passaram a disputar espaço na arena da saúde, particularmente os gestores municipais e estaduais e os conselhos paritários formados nos três níveis de governo, como exigência da legislação. A mobilização em torno da viabilização financeira da assistência pública mostrou a visibilidade e a importância política que ela assumira, bem como a rede de instituições e atores em torno do SUS, inclusive os prestadores privados e profissionais de saúde, cujos interesses são diretamente afetados pela política de saúde. Duas lógicas operam na política de saúde: uma publicista, no sentido de viabilizar o SUS, processo que de certa forma se tornou irreversível; e outra privatista, no sentido de ampliar a cobertura por planos e seguros de saúde, constituindo, ou consolidando, dois segmentos diferenciados, que se traduzem em duas estruturas institucionais e em um sistema de saúde dual.

Expressão e consolidação dessa dualidade, bem como do volume e da importância que o segmento privado assumiu, concomitantemente às mudanças institucionais no sentido de implantação do SUS, na década de 90 ganhou relevo o debate envolvendo diferentes atores, tanto governamentais quanto da sociedade civil, sobre a regulamentação da 'assistência médica supletiva'. Tal debate culminou com a promulgação da lei 9.665, em 19/6/1998, que dispõe sobre os planos privados de assistência à saúde. Em vez de um indicativo simplista de 'fracasso' do SUS, a regulamentação mostra que se tratou de colocar sob o controle governamental atividades que já estavam suficientemente institucionalizadas, de tal forma que o dispositivo constitucional que garantiu a assistência pública a todos por si só não demoliria. A regulamentação não fará nada mais do que completar o processo de consolidação do sistema de saúde dual do país, confrontando a lógica da assistência médica como uma mercadoria ou um produto à lógica do SUS, baseada na noção de direito de cidadania. O processo político que resultou na regulação da assistência privada é o objeto do próximo capítulo. 



\section{5}

\section{A Regulação da Assistência à Saúde Suplementar}

Da perspectiva analítica desenvolvida neste trabalho, considera-se que a década de 90 sintetiza a dupla trajetória da assistência à saúde no Brasil no período de quatro décadas, sendo ao mesmo tempo a época em que são introduzidas inovações institucionais que expressam tanto a reforma da saúde quanto a conjuntura contemporânea. É nessa década que vai se iniciar e, em grande medida, se consolidar a implantação do SUS, que se traduz em mudanças institucionais no âmbito da assistência pública. Concomitantemente, vai se definir uma política regulatória voltada para o segmento privado da assistência à saúde, que também será acompanhada de mudanças na configuração institucional do governo. Apesar de qualitativamente distintas das alterações institucionais decorrentes da implantação do sistema público universal, essas mudanças vão também revelar a face de continuidade que caracteriza o padrão de assistência vigente, expressão da própria trajetória da política de saúde, cuja principal conseqüência foi a consolidação de um modelo dual. A regulação da assistência privada, no final da década, formaliza essa dualidade do ponto de vista legal, normativo e institucional, uma vez que, a partir daí, os dois sistemas de assistência passam a ser objeto da política de saúde de forma explícita, e não apenas por meio de não-decisões.

Como evidência desse argumento, este capítulo, prioritariamente, pretende mostrar como a constituição do marco regulatório da assistência privada consolida o formato dual por meio do qual se concretizara historicamente a assistência à saúde. Nesse sentido, a definição da política regulatória não indica 
uma mudança estrutural na forma de atuação governamental no âmbito da saúde, no sentido preconizado pelas reformas na concepção e na forma de atuação do Estado que caracterizam o período. De uma perspectiva normativa, estas têm como uma de suas características a reintrodução na agenda pública do tema da regulação, como forma de intervenção do Estado no mercado e na sociedade, em substituição à intervenção direta que caracterizou o desenvolvimento do Estado de Bem-Estar ou desenvolvimentista. Embora não deixe de traduzir essa mudança de concepção do Estado, a regulamentação do setor privado não é o resultado de uma mudança na forma de atuação do Estado brasileiro no campo da saúde em decorrência de um processo deliberado de privatização; ao contrário, passa-se a regular uma atividade privada que já existia desde os anos 60. Ao mesmo tempo, essa regulação do mercado não elimina a atuação estatal 'tradicional', baseada na ação direta. Ao contrário, o processo regulatório coincide com o de implantação da reforma da política de saúde, baseada nos princípios da universalização e da responsabilidade governamental pela garantia do direito à saúde, que significou um aprofundamento da intervenção estatal no setor, na forma de financiamento, gestão e produção de serviços. Além disso, a regulação da assistência privada significou maior intervencionismo sobre uma atividade até então auto-regulada. $\mathrm{O}$ arcabouço legal regulatório, que começa a ser montado no final da década de 90 , expressa a dualidade das formas de intervenção ao restringir sua abrangência ao segmento dos planos e seguros de saúde privados, não tratando sequer da vinculação entre os segmentos público e privado, bem como das relações do SUS com a rede prestadora privada. Se a primeira dessas questões continua indefinida, a segunda permanece vinculada ao escopo da regulamentação no âmbito do SUS, de forma frágil e pouco institucionalizada.

Se a regulação não está associada à privatização da assistência à saúde, uma vez que formas privadas de assistência lhe são anteriores e não são decorrentes de um movimento deliberado nesse sentido nos anos 90, o formato institucional assumido pela regulação da assistência suplementar reflete, entretanto, o contexto de reforma do Estado e dos mecanismos de gestão pública que caracterizam o período. O efetivo movimento de reforma no escopo e na forma de atuação estatal no caso brasileiro se dá em consonância com o movimento internacional desencadeado a partir dos anos 70, articulado a um 
diagnóstico de crise do Estado que foi associada, principalmente, à crise das formas anteriores de regulação estatal. Esse movimento se traduziu em reformas nas modalidades de gestão pública, entre elas nos mecanismos institucionais de regulação governamental. No caso da saúde, isso vai se expressar na criação de uma agência reguladora independente, seguindo um modelo originado nos Estados Unidos e adotado nos países europeus que recentemente tinham privatizado serviços públicos anteriormente regulados pela propriedade pública.

Com base nesses argumentos, neste capítulo é analisada a constituição do modelo regulatório da assistência privada, considerando tanto os aspectos políticos relativos ao processo decisório quanto a configuração do arranjo institucional que assumiu a forma de uma agência reguladora. Após uma apresentação breve do referencial normativo da questão da regulação, que se vincula ao contexto político-ideológico de reforma do Estado, são analisados os processos de introdução do tema da regulação dos planos e seguros de saúde na agenda pública e de constituição do arcabouço legal regulamentador da atividade. Essa análise é feita, em primeiro lugar, com base na reconstituição do processo legislativo que resultou na promulgação pelo Congresso Nacional, em junho de 1998, da lei 9.656, que dispõe sobre os planos e seguros privados de assistência à saúde, e da evolução do processo regulatório que culminou com a criação da Agência Nacional de Saúde Suplementar (ANS), em dezembro de 1999. Em seguida, são tratados alguns aspectos substantivos da regulamentação e os seus resultados mais recentes, bem como os conflitos entre os vários segmentos afetados que permitem problematizar a adequação do modelo regulatório aos fins que foram propostos. ${ }^{183}$

$\mathrm{Na}$ análise desses processos, enfatiza-se a dimensão política, enfocando a ação dos atores previamente constituídos no decorrer do desenvolvimento da assistência à saúde privada a partir dos anos 60, mas também de novos atores,

183 Para a elaboração deste capítulo foram utilizadas diferentes fontes, tanto primárias quanto secundárias, como: documentos relativos à tramitação da lei 9.658/98 no Congresso Nacional, incluindo as diversas audiências públicas e as discussões no plenário; notas taquigráficas e textos de referência de um simpósio realizado no Congresso sobre o tema; publicações da Agência Nacional de Saúde Suplementar (ANS); documentos das entidades de profissionais de saúde e de entidades representativas dos segmentos que compõem o mercado de saúde; jornais; entrevistas com diretores da ANS e representantes de operadoras de planos de saúde, além de outras fontes bibliográficas. 
particularmente os movimentos de defesa dos consumidores, que, embora mais recentes na arena política, expressam também o crescimento prévio dos planos de saúde individuais nos anos 80 , que engendrou relações tipicamente de consumo entre usuários e operadoras comerciais de planos de saúde. Mas, se por um lado os conflitos observados na arena decisória da saúde, que refletem o desenvolvimento de uma rede complexa de instituições e atores organizacionais, tiveram um papel importante no estabelecimento de uma política regulatória, por outro lado o formato institucional assumido pela regulação da assistência suplementar reflete o contexto de reforma do Estado e dos mecanismos de gestão pública que caracterizam a década de 90 no Brasil, em consonância com o movimento internacional nesse sentido.

A trajetória recente da regulação tem como resultado a formalização de um sistema de saúde dual, que se expressa, inclusive, por meio dos mecanismos de gestão, de tal forma que passam a conviver duas lógicas de atuação governamental no mesmo locus institucional. O Ministério da Saúde assume, assim, as características tanto de um Estado regulador, quando trata do mercado privado de saúde, quanto de Estado positivo ou intervencionista, quando atua por meio do SUS.

\section{O Contexto Normativo da Regulação da Assistência Suplementar: reforma do Estado e as novas formas de intervenção}

O tema da reforma do Estado e, conseqüentemente, da administração pública, de forma a adequá-la às novas demandas que se apresentam ao Estado, dominou a agenda política internacional desde os anos 80. Em linhas gerais, a reforma do Estado foi vista como uma conseqüência da crise do Estado intervencionista, na sua versão de Estado de Bem-Estar ou desenvolvimentista, como decorrência das mudanças no funcionamento da economia desencadeadas a partir de meados dos anos 70 e associadas aos processos que receberam a denominação genérica de globalização. Em uma leitura predominantemente econômica, as explicações para a crise do Estado são vinculadas à crise econômica internacional que se inicia após os choques do petróleo, ainda 
na década de 70, à qual se seguiram políticas recessivas em um quadro de crise fiscal e de endividamento dos governos, que passaram a buscar recursos no mercado financeiro internacional, iniciando-se um ciclo de desregulamentação e globalização financeira. Os processos de transformação econômica significaram o rompimento das amarras regulatórias tradicionais do Estado em razão do processo de desterritorialização do capital, revelando a necessidade de redefinição dos estados-nacionais e de formação de um novo marco de regulação. O resultado disso se traduziu em algumas tendências gerais, como a diminuição da participação do Estado como produtor direto de bens e serviços por meio de privatizações, concessões e desregulamentação; o aumento do incentivo e da orientação dos investimentos privados em áreas consideradas estratégicas ou prioritárias pelo setor público; e o incremento das atividades de regulação e de parcerias com diferentes atores da sociedade. Se em uma primeira fase, ainda na década de 80 e sob influência do chamado neoliberalismo, a proposta de reforma era no sentido de diminuir o tamanho do Estado e de priorizar a atuação de um mercado desregulado, a década de 90 trará a preocupação com a reestruturação e o fortalecimento institucional do setor público, via mudança do modelo de intervenção econômica e o estabelecimento de novas formas de gestão, entendidas como a construção de um modelo pós-burocrático.

As propostas e práticas de transformação da administração pública vão se centrar principalmente nos seguintes aspectos: o estabelecimento de uma administração mais orientada para resultados do que por procedimentos e normas auto-referidas; a flexibilização do funcionamento interno do setor público em termos de gestão e contratação de pessoal, com o objetivo de aumentar a eficiência e a efetividade das ações; a ampliação do conceito de público superando a idéia do Estado como único provedor de serviços públicos, enfatizando as parcerias com o setor privado, lucrativo ou não; e a descentralização dos serviços públicos básicos para governos subnacionais.

No contexto dessas reformas, a regulação governamental ganhou preeminência como uma forma central de intervenção do Estado não apenas no mercado, que é o fenômeno mais antigo, mas em diferentes setores, como na proteção do consumidor, na saúde ocupacional e na proteção ambiental. De uma perspectiva normativa, a regulação estaria substituindo outras formas de 
intervenção e se tornando um importante instrumento de política pública, particularmente substituindo a propriedade pública e a ação governamental direta como forma de assegurar serviços públicos eficientes. A criação de um aparato institucional voltado para a regulação torna-se a contrapartida do processo de privatização, de forma que a retirada do Estado das funções produtivas é acompanhada de transformações nas suas atividades regulatórias, que assumem formas variadas. ${ }^{184}$

Nos anos 90, ocorre um processo de difusão internacional de paradigmas de reformas regulatórias que tem como base conceitual a informar a ação do Estado as teorias normativas da regulação desenvolvidas na década de $70 .{ }^{185}$ Paralelamente, ocorreu a criação de agências reguladoras em vários países europeus e latino-americanos, processo associado ao movimento de privatização e de difusão do modelo gerencial para a administração pública conduzido por agências multilaterais e empresas internacionais de consultoria (Melo, 2000). Nesse contexto, a privatização de serviços públicos foi seguida de regulação, cabendo às agências reguladoras inspecionar os serviços privatizados, como telecomunicações, eletricidade e água. Mesmo sendo providos de forma privada, a tendência internacional tem sido de que os serviços públicos e outros setores considerados importantes ao interesse público passem a ser submetidos a regras desenvolvidas e aplicadas por agências especializadas, que funcio-

184 Como descrevem Baldwin, Scott e Hood (1998), desenvolveram-se abordagens analíticas distintas para a compreensão do processo regulatório, não existindo nem mesmo um significado único para o termo. Esses autores identificam três definições na literatura. Na primeira, a regulação é entendida como um conjunto de regras impositivas, acompanhadas de algum mecanismo - de modo mais típico uma agência pública - para monitorar e promover submissão a essas regras. O objetivo desse regime de regulação pode ser tanto de caráter social quanto econômico, e pela regulação busca-se encorajar formas de atividades consideradas úteis. Em uma segunda definição, bem mais ampla, a regulação é entendida como todos os esforços das agências estatais para dirigir a economia. Inclui elaboração de regras e sua aplicação por meio de sistemas de coação e, além disso, outros instrumentos governamentais, como a taxação, o estabelecimento de incentivos para comportamentos socialmente desejáveis ou a criação de condições que permitam que essas atividades aconteçam. Na terceira concepção a regulação se refere a todos os mecanismos de controle social, incluindo processos não intencionais e não governamentais, como, por exemplo, o desenvolvimento de normas sociais e os efeitos de mercados, por meio das atividades de empresários e consultores em modificar comportamentos e modelar campos regulatórios. Ao passo que as duas primeiras definições se baseiam na atividade intencional do Estado, voltada para a modificação do comportamento e tendo como referência regras impositivas, na terceira a noção de intencionalidade desaparece, e qualquer coisa que produza efeitos no comportamento pode ser considerada como regulatória.

185 Para análise dessas teorias e para uma revisão da literatura sobre regulação, ver Melo (2000), Baldwin, Scott e Hood (1998) e Sunstein (1990, apud Melo, 2000). 
nam como autoridades administrativas independentes, operando fora da linha de controle hierárquico pelos ministérios do governo central.

Majone (1999) analisa a questão a partir do movimento de passagem do Estado intervencionista ou positivo para o Estado regulador e identifica um processo de convergência institucional no sentido de o modelo das agências independentes se tornar o padrão regulatório dominante. ${ }^{186}$ A concatenação de várias estratégias básicas, como a privatização, a liberalização e a desregulação, e a austeridade fiscal, a integração econômica e monetária, tem concorrido para limitar o papel do Estado intervencionista ou positivo ao restringir seu poder de tributar e de gastar, mas, ao mesmo tempo, aumenta seu poder normativo. Como aparente paradoxo, o desenvolvimento de novas formas de regulação coincide com a defesa da desregulamentação sob influência do neoliberalismo e da nova direita nos anos 80 e 90 . Mas o paradoxo é mais aparente do que real, na medida em que o que se observa não é um desmantelamento de toda a regulação governamental, mas uma combinação de desregulação e 'nova' regulação, esta última abrangendo as relações entre o Estado, prestadores de serviços públicos e usuários, em substituição às funções diretamente produtivas desses serviços pelo Estado. Por sua vez, as políticas de desregulação suprimidas no contexto de reforma do Estado não se referem a bens e serviços de natureza pública - embora exista um interesse público envolvido -, mas a outras formas de intervenção voltadas para corrigir desequilíbrios econômicos ou sociais (Oslzlac \& Felder, 2000). ${ }^{187}$

Análises das ações governamentais de caráter menos normativo identificam processos simultâneos de desregulação e rerregulação, dado que, embora os processos de desregulamentação dos setores financeiros e liberalização do comércio exterior tenham sido tratados como desregulação, não se trata disso,

186 Para uma crítica a essa perspectiva da convergência com base na identificação das especificidades nacionais dos padrões regulatórios, ver Melo (2001) e Boschi e Lima (2002).

187 Entre esses, o fornecimento de insumos críticos, o uso de estoques de intervenção para regular os mercados, a fixação de paridade cambial ou da taxa de juros, a fixação do salário mínimo etc. (Oslzlac \& Felder, 2000). Esses autores destacam como área de intervenção estatal vinculada à função regulamentadora que não foi afetada no movimento de reforma do Estado aquela relativa às "funções de habilitação, controle e inspeção de estabelecimentos privados e públicos dedicados à produção e comercialização de diversos bens de consumo (alimentos, medicamentos) ou à prestação de determinados serviços (i.e. de saúde, educacionais, recreativos, culturais, de segurança) em aspectos relativos às condições de produção, qualidade dos bens ou serviços, observação de normas de moralidade pública, etc.” (Oslzlac \& Felder, 2000: 6). 
uma vez que a liberalização se faz acompanhar de transformações nas atividades regulatórias do Estado voltadas para o objetivo de garantir credibilidade à regulação - variável crucial para a capacidade governamental de atrair investimentos (Vogel, 1996, apud Melo, 2000). É nessa perspectiva que a independência das agências reguladoras é vista como uma garantia de credibilidade regulatória para os investidores, fundada na obediência a regras, e não no exercício da discrição, o que permite assegurar que não haverá mudanças nas regras do jogo (Melo, 2001).

Na perspectiva de teorias econômicas que constituem a base normativa para a ação do Estado, as políticas regulatórias têm como objetivo corrigir vários tipos de falhas do mercado, de modo a melhorar sua eficiência, como: as falhas de competição ou o poder de monopólio que gera distorções na alocação de recursos pela tendência de elevação de preços; as externalidades negativas, que impõem perdas sem compensações correspondentes; a informação incompleta ou a assimetria de informações entre os agentes do mercado; e a provisão insuficiente ou inadequada de bens públicos que produzem os mercados incompletos. Essas falhas de mercado ocorrem quando não são satisfeitas uma ou mais condições do teorema segundo o qual em determinadas condições os mercados competitivos levam a uma alocação ideal de recursos. ${ }^{188}$ A regulação, particularmente quando delegada a agências reguladoras independentes, permitiria a correção de falhas do mercado, de modo a aumentar a eficiência das transações. ${ }^{189}$ A intervenção do governo nesses casos se daria em nome dos consumidores, da proteção de contratos e da provisão de bens públicos. No caso da regulação de serviços públicos privatizados, supõe-se uma modalidade de intervenção estatal segundo a qual as relações entre prestadores e usuários é intermediada pelas ações do Estado destinadas

${ }_{188}$ Como é bastante conhecido, de acordo com a economia do bem-estar, esse pressuposto se assenta em dois teoremas: 1) a condição de eficiência paretiana é atingida quando nenhuma mudança na alocação de recursos pode ser realizada de forma a melhorar o bem-estar de um indivíduo sem implicar a redução do bem-estar de outro; 2) em condições ideais, os mercados competitivos produzem uma situação Pareto-ótima na alocação de recursos.

189 Como destaca Melo (2000), essas situações de falhas de mercado produzem a rationale para a ação regulatória e fornecem uma base normativa para a intervenção do Estado, mas não uma análise da prática regulatória de governos, o que é feito pelas teorias positivas da regulação (Stigler, 1975; Peltzman, 1989; Becker, 1983) e pelas teorias neo-institucionalistas da regulação (Noll, 1989; Moe, 1997; Doner \& Schneider, 1999). Foge ao escopo deste trabalho tratar essa segunda questão revisada por Melo, que tem sido objeto principalmente da economia. 
a proteger os interesses públicos envolvidos, especificamente os interesses dos consumidores ou usuários (Oslzlack \& Felder, 2000).

Uma política regulatória, na tipologia de Wilson, permite maior convergência entre os interesses afetados pela política, na medida em que pode oferecer soluções que beneficiam a todos, sendo assim uma política de soma positiva (Wilson, 1995, apud Costa, 2001). Mas existe sempre a possibilidade de que a regulação induza o estabelecimento de laços clientelistas entre reguladores e grupos regulados, com o risco da captura da função reguladora por interesses particularistas. ${ }^{190}$

Embora fuja ao escopo deste trabalho analisar as implicações decorrentes da natureza das políticas regulatórias, alguns aspectos merecem ser destacados por sua importância para a interpretação do processo político-decisório da regulação da assistência à saúde, na medida em que a formulação desse tipo de política leva a alterações na arena política. As políticas regulatórias são bastante distintas daquelas que exigem dispêndio direto de recursos públicos. Uma diferença é relativa à fonte de poder governamental, que decorre da criação de regras, em vez de ser derivada da tributação e da despesa governamental, que tem impacto direto na sociedade ou em segmentos dela. Assim, o objeto principal do conflito político é a revisão e o controle da formulação de regras, ou o controle da normatividade, em vez da disputa pela alocação de recursos, que caracteriza o conflito tradicional centrado no processo orçamentário. Em conseqüência, arenas de disputa pelo poder de normatizar passam a ser constituídas em torno dos novos entes reguladores. A mudança para o Estado regulador leva também ao surgimento de novos atores na arena política ou ao fortalecimento do poder de velhos atores (Majone, 1999). Entre estes últimos, o Judiciário se transforma em um protagonista ativo do jogo administrativo e na formulação de políticas, na medida em que se torna o locus para a solução de disputas entre agentes normativos governamentais e agentes autônomos, e ainda para o exame judicial das decisões das agências. Entre os novos atores, são importantes os especialistas e os reguladores, uma vez que a regulação

$\overline{190}$ A teoria da captura foi desenvolvida por Stigler (1975), segundo a qual existe o risco de o regulador, buscando maximizar seus próprios interesses, identificar o interesse de um determinado agente do mercado como o interesse da própria missão reguladora. Em muitos casos, os efeitos da política regulatória seriam contrários aos previstos pela teoria normativa. 
depende muito de conhecimentos específicos, dos quais, do ponto de vista normativo, deriva grande parte do poder discricionário dos reguladores. Além desses, surgem novos grupos pluralistas, que agem intensamente no Estado regulador, como aqueles centrados na defesa do consumidor, na proteção ambiental ou nas questões de gênero - os chamados temas pós-industriais.

Os pressupostos normativos que justificam a criação de agências reguladoras creditam a essa inovação institucional a possibilidade de maior eficiência, por serem idealizadas como organizações flexíveis e altamente especializadas, com grande autonomia decisória, o que lhes daria credibilidade regulatória. Em razão dessas qualidades, é esperado que as agências reguladoras tenham maior comprometimento com estratégias de longo prazo, dificilmente obtido em regimes democráticos, nos quais a descontinuidade das políticas é usual pela própria natureza do regime. O pressuposto por detrás da defesa da independência das agências reguladoras, em relação tanto ao Executivo quanto ao mercado, é que isso lhes permitiria alcançar seus objetivos sem interferências políticas e pressões do poder econômico em questões em que deva prevalecer a escolha técnica. ${ }^{191} \mathrm{~A}$ independência das agências implica, assim, um modelo de insulamento burocrático com base no pressuposto de que o ambiente democrático põe em risco a racionalidade econômica.

Do ponto de vista da teoria democrática, a atuação das agências independentes suscita questões relevantes de ordem normativa, relativas à sua legitimidade e responsabilização, e o risco de insulamento burocrático e de desvio de poder. A delegação de tarefas a agências independentes gera, em princípio, um deficit democrático, na medida em que elas não se inserem no modelo tradicional de checks and balances, ou de responsabilização horizontal, e menos ainda são responsáveis diretamente ante os eleitores. A autonomia e a independência representam uma ameaça ao interesse público, uma vez que agentes não-eleitos tomam decisões relevantes para a sociedade, gerando uma tensão entre delegação e responsabilização ou entre autonomia e controle (Melo, 2000,

191 Dotadas de autonomia decisória, as agências reguladoras "passam a desempenhar funções formalmente de competência do Executivo (concessão e fiscalização de atividades e direitos econômicos), do Legislativo (normas, procedimentos com força legal sob a área de jurisdição) e do Judiciário (julgar e impor penalidades, interpretar contratos e obrigações). No campo jurídico, essa multifuncionalidade é descrita como outorga de competência normativa sobre um dado setor mediante a técnica de delegação legislativa (...)" (Farias \& Ribeiro, 2002: 83). 
2001; Boschi \& Lima, 2002). ${ }^{192}$ As contra-argumentações a essa questão sugerem a possibilidade de conciliar a independência e a responsabilização das agências por meio de mecanismos indiretos de controle que incluem normas claras de desempenho, exigências de transparência, definição clara dos objetivos e limites dentro dos quais se espera que a agência opere e profissionalismo para resistir à interferência externa. Para controle do mérito das decisões ou do desempenho, o contrato de gestão é visto como um dos principais instrumentos.

É nessa perspectiva que a delegação de poder decisório a agências reguladoras independentes é considerada como um mecanismo institucional capaz de fornecer uma solução para o risco de captura da função regulatória por interesses particularistas, em razão das características das agências, como: a estabilidade dos dirigentes, que têm mandatos definidos em lei; a independência financeira e gerencial; os critérios técnicos de escolha; a transparência decisória; e o poder para mediação e arbitramento de conflitos. Para garantir a transparência, as agências devem estabelecer canais de comunicação com os consumidores, elaborar consultas prévias à tomada de decisões e publicar documentos preliminares para a apreciação dos interessados. ${ }^{193}$

192 Como sintetizam Boschi e Lima (2002: 231), "o risco de qualquer delegação consiste na possibilidade de o agente poder ultrapassar os limites do seu mandato, gerando a necessidade de responsabilização ou controle. (...) Quando a delegação está associada a objetivos definidos politicamente no sentido de assegurar a credibilidade, os governantes não poderiam impor muitos controles ex post sobre os agentes sem colocar em risco os próprios objetivos originais da delegação".

193 Curiosamente, a admissão da possibilidade de uma atuação técnica independente, como forma de evitar a captura dos entes governamentais pelos interesses daqueles que deve regular, parece invalidar a própria teoria, na medida em que é atribuído ao conhecimento técnico e especializado e à autonomia a possibilidade de fornecer um escudo para impedir que interesses particularistas sejam perseguidos no processo regulatório. A passagem de indivíduos auto-interessados para indivíduos que do conhecimento específico sejam capazes de agir de forma mais eficiente não fica suficientemente explicada. Além disso, a questão da eficiência não é problematizada, assumindo-se a existência de uma resposta única que seja a mais eficiente e capaz de harmonizar os interesses em jogo, eliminando-se a pactuação política. Sem aprofundar a discussão desses pressupostos, entretanto, considero adequada a formulação de Reis (1994) ao problematizar a perspectiva técnica da administração, segundo a qual para buscar a eficiência bastaria ajustar a máquina do Estado. Reis enfatiza, entretanto, que o problema da administração eficiente não pode ser dissociado da política e envolve a garantia da operação democrática do Estado. Desta forma, o Estado eficiente supõe a implantação de um Estado-arena, no qual os diversos interesses devem se fazer presentes. A crítica de Subirats (1996) segue direção semelhante ao indicar, como um dos desenvolvimentos de uma gestão pública democrática que combine eficiência e participação, a necessidade de superar os marcos das racionalidades técnicas e de impor uma lógica decisória baseada muito mais no compromisso do que em uma possível racionalidade. Nesta perspectiva, sem participação, a eficiência ou não o é ou não compensa os deficits de transparência e de responsabilidade que acarreta. 
No caso brasileiro, a discussão sobre a reforma do Estado tomou corpo na década de 90, associada às iniciativas de reformas originadas do governo federal. ${ }^{194}$ Durante o governo Collor, no início da década, foram tomadas as primeiras medidas no sentido de reduzir o Estado e romper com o passado intervencionista. O governo do presidente Fernando Henrique Cardoso consolidou a reforma do Estado e, por meio de mudanças constitucionais e legais, abriu caminho para a reestruturação da ordem econômica e para a refundação do Estado e da sociedade de acordo com os parâmetros consagrados internacionalmente (Diniz, 2001). As principais reformas incluíram: abertura do mercado, privatizações de empresas governamentais e flexibilização do monopólio de outras atividades, com repasse para o setor privado de atividades econômicas, além de serviços públicos, como telecomunicações e energia elétrica, o que exigiu mudanças no papel regulador do Estado. No âmbito interno da gestão pública, foi realizada uma reforma administrativa com o objetivo declarado de tornar a burocracia governamental mais flexível e eficiente, mas que teve o caráter muito maior de redução dos gastos e de criar novas formas de provisão de serviços públicos. ${ }^{195}$

O debate nacional sobre a nova regulação de mercados, do qual nasceram as primeiras experiências de agências reguladoras, toma corpo a partir de 1995. A justificativa para a necessidade de estabelecer e reforçar instâncias setoriais de regulação, a exemplo de outras experiências internacionais, foi no sentido de proceder a reformas institucionais para modernizar a estrutura regulatória, "considerada essencial para aumentar a eficiência das economias nacionais, potencializando suas condições de competitividade e de adaptação a mudanças, conferindo segurança aos investidores e resguardando os direitos

$\overline{194}$ A literatura sobre o tema é bastante ampla e perpassa a maior parte da discussão sobre a política e a economia contemporâneas. Foge ao escopo deste trabalho discuti-la. Apenas como exemplos de autores que discutem especificamente a reforma do Estado e da administração pública para o caso brasileiro, citaria Azevedo (1998), Bresser Pereira (1996a, 1996b, 1997, 1998a, 1998b), Abrúcio (1997), Abrúcio e Costa (1999), Melo (1996, 1999), Diniz (1995a, 1995b, 1997, 2001), Boschi (1999).

195 Exemplos da proposta de flexibilização da administração pública foram: a definição da hipótese de perda de estabilidade dos funcionários públicos por insuficiência de desempenho; o fim da obrigatoriedade de um Regime Jurídico Único; a supressão da isonomia entre os três poderes; e a ampliação da autonomia gerencial, orçamentária e financeira de órgãos e entidades da administração direta e indireta, mediante contrato que tenha como objeto a fixação de metas para desempenho. 
dos consumidores em mercados imperfeitos" (Farias \& Ribeiro, 2002: 76). ${ }^{196}$ Com a aceleração de privatizações e o ajuste estrutural da economia, iniciou-se um projeto de transformação institucional do Estado brasileiro na direção de um modelo regulador que foi consubstanciado no Plano Diretor da Reforma do Aparelho do Estado (PRDE), elaborado em 1995 pelo Ministério de Administração e Reforma do Estado (Mare), criado com esse objetivo específico, expressando o tratamento prioritário dado pelo governo à questão da reforma ${ }^{197}$ Embora não tenha feito uma caracterização maior das funções reguladoras, o PDRE tinha a proposta de estabelecer uma nova institucionalidade dentro do paradigma do Estado regulador e previa a criação de agências reguladoras para a execução de ações de regulação. Nos setores voltados para a provisão de serviços públicos, a passagem de formas estatais para formas privatizadas estimulou as reformas regulatórias, visando adequar esses setores à gestão pela iniciativa privada. A definição de marcos regulatórios para a provisão de serviços públicos é inaugurada pela Lei de Concessões (lei 8.985/95). ${ }^{198}$ Como desdobramentos da proposta de construção de um marco legal para os entes reguladores e completando o programa de desestatização iniciado em 1990, foram criadas as agências reguladoras independentes para os setores privatizados de energia elétrica, telecomunicações e petróleo: a Agência Nacional de Energia Elétrica (Aneel), pela lei 9.427/ 1996; a Agência Nacional de Telecomunicações (Anatel), pela lei 9.472/97, e a Agência Nacional do Petróleo (ANP), pela lei 9.478/97. Nos anos seguintes, foram criadas agências de regulação em distintas áreas, como recursos naturais,

$\overline{196}$ Os autores eram na época, respectivamente, secretário executivo adjunto e assessora do secretário executivo do Ministério do Planejamento, Orçamento e Gestão, que incorporou o extinto Ministério da Reforma do Estado, criado no governo de Fernando Henrique Cardoso.

197 “O PRDE teve como objetivos garantir a governança mediante novos modelos de financiamento, de organização e de gestão do setor público; aprofundar a descentralização de funções para Estados e municípios; limitar, em princípio, a ação do Estado às atividades exclusivas, reservando as não-exclusivas ao setor público não-estatal e a produção de bens e serviços, à iniciativa privada" (Farias \& Ribeiro, 2002: 77). A crítica que esses autores apresentam ao PRDE é que ele circunscreveu-se a uma visão institucional focada na proposição de modelos organizacionais e de gestão que referenciaram a dimensão administrativa da reforma regulatória, além de não ter se articulado com as políticas de privatização e de estímulo à concorrência.

198 A Lei de Concessões e a legislação setorial específica estabeleceram direitos e obrigações das empresas concessionárias de serviços, a forma de atuação do Estado no exercício da função regulatória e os mecanismos para resolução de conflitos de forma ágil e flexível (Araújo \& Pires, 2000). 
transporte, cinema e desenvolvimento da Amazônia e do Nordeste. Como sugerem Boschi e Lima (2002), a multiplicação de agências parece não ter mais a ver com a racionalidade inicial e os objetivos doutrinários da reforma do Estado, mas segue uma lógica voltada mais aos graus de liberdade conferidos pelo próprio estatuto de autarquia - portanto livre das limitações impostas à administração direta - do que às metas de eficiência e credibilidade. ${ }^{199}$

No caso da assistência à saúde, foi feita uma importação desse mecanismo institucional, usado inicialmente no caso da transferência para o setor privado de atividades voltadas para a provisão de serviços públicos. Sob a justificativa de se constituírem em áreas de grande interesse social, foram criadas, em 1999, duas agências reguladoras vinculadas ao Ministério da Saúde: a Agência Nacional de Vigilância Sanitária (Anvisa) e a Agência Nacional de Saúde Suplementar (ANS), esta na última fase do processo de estabelecimento de mecanismos e instâncias específicas para a regulação da assistência à saúde privada. A ANS deu uma direção mais forte ao processo de regulação iniciado com a regulamentação dos planos privados de saúde pela lei 9.656/98 e expressou os pressupostos normativos difundidos internacionalmente.

\section{A Regulamentação dos Planos e Seguros de Saúde - formação da agenda e processo decisório: atores, interesses e idéias}

\section{A introdução na agenda pública da regulamentação dos planos e seguros de saúde: a composição da arena e dos temas}

Ao definir as ações e os serviços de saúde como de relevância pública, a Constituição estabeleceu que cabe ao Poder Público dispor sobre sua regulamentação, fiscalização e controle (artigo 197). Apesar disso, durante o processo constituinte não foram definidos mecanismos de regulação das atividades privadas no campo da saúde, embora elas proliferassem no país desde os

199 Boschi e Lima (2002: 229-230) mostram como por meio da proliferação de agências “misturam-se objetivos, criam-se esferas de regulação em áreas que não constituem monopólios naturais, além de se restaurarem, pela via da atividade regulatória do Estado, instâncias de fomento já extintas e mais próximas de uma concepção de Estado positivo intervencionista do que de um Estado regulador". 
anos 60 e principalmente nos 80 , praticamente à margem de qualquer regulação governamental. Durante a década de 90 , no contexto de dificuldades de implantação do SUS, a assistência privada passou a ser objeto de debates em diferentes perspectivas e conformou uma demanda pela regulação governamental do setor supletivo de assistência à saúde que levou à introdução da questão na agenda pública. Em meados da década, ela alcançou o debate parlamentar que culminou com a promulgação pelo Congresso Nacional da lei 9.656/98, que dispõe sobre os planos e seguros privados de assistência à saúde. Isso se deu após tramitação de nada menos do que 23 projetos sobre a questão no período de sete anos, a maioria proposta no período 1996/97, quando a discussão sobre o controle e a regulamentação do mercado de saúde ganhou grande visibilidade pública.

Duas perspectivas distintas caracterizaram o debate público que precedeu a discussão no âmbito do Legislativo, objetivadas em atores distintos e expressas em idéias também diferenciadas. De um lado, uma perspectiva eminentemente econômica e, de outro, a perspectiva assistencial. Pela primeira, a defesa da regulamentação partiu do setor econômico do governo representado pelo Ministério da Fazenda, para quem os planos e seguros de saúde eram vistos como uma atividade econômica e como um mercado a ser aperfeiçoado para a expansão das empresas de assistência médica suplementar. Nesse sentido, defendia-se a abertura para o capital estrangeiro e a definição de regras para a constituição de reservas e demonstração de solvência para a permanência de empresas no mercado. Essa posição reflete a influência das idéias difundidas internacionalmente, particularmente pelo Banco Mundial, que recomendava para a agenda brasileira dos anos 90 que o governo assumisse o papel regulatório do segmento de planos e seguros privados para promover um ambiente competitivo entre as empresas, e destas com as opções financiadas com recursos públicos, favorecendo o aumento da eficiência (Bahia, 1999). Essa perspectiva era endossada por seguradoras que atuavam na saúde e que queriam tratamento igual para todos os demais segmentos: medicina de grupo, cooperativas médicas e sistemas de autogestão (organizados e administrados por empresas para seus empregados). Na condição de integrantes do Sistema Nacional de Seguros Privados, os seguros de saúde constituíam o único segmento da assistência privada sujeito a alguma normatização pública desde a década de 60 , 
limitada, porém, aos aspectos ligados à sua condição de instituições de seguro, não estando reguladas as atividades assistenciais. A primeira proposta de regulamentação partiu da Superintendência de Seguros Privados (Susep) do Ministério da Fazenda, órgão executor das decisões do Conselho Nacional de Seguros Privados (CNSP), e expressava os interesses das seguradoras ao propor colocar sob seu controle as atividades da medicina de grupo e a regulação das atividades de comercialização de planos e seguros de saúde (Bahia, 1999).

Do lado assistencial, a defesa da regulamentação do setor entrava para a agenda pública, na perspectiva dos interesses dos consumidores, que cada vez mais se posicionavam nos órgãos de defesa do consumidor contra as restrições de cobertura e os aumentos de preços dos planos de saúde. As denúncias contra a negação de atendimento e a elevação de preços, considerados abusivos, foram na época objeto de numerosas intervenções do Judiciário em prol dos usuários de planos de saúde e tiveram o apoio das entidades médicas, que se posicionaram contra o controle da prescrição e realização de procedimentos diagnósticos e terapêuticos praticado pelas operadoras de planos de saúde como forma de diminuir custos - comportamento considerado pela categoria médica como um cerceamento da sua autonomia, em prejuízo da qualidade da assistência. Além dos consumidores e profissionais médicos, a demanda por ampliação de cobertura aglutinava outros prestadores de serviços, como os hospitais, a quem interessava ampliar o mercado de serviços de saúde.

Um terceiro conjunto de questões em torno das quais se consolidou a pressão pela regulação do setor privado, embora de menor impacto, partiu dos gestores do sistema público. Estes passaram a propor o ressarcimento pelos atendimentos aos clientes de planos e seguros privados que fossem realizados nas dependências de estabelecimentos públicos ou conveniados com o SUS. Essa demanda era uma contrapartida da constatação de ocorrência de dupla cobrança ou de transferência para o SUS de pacientes que tinham contratos com planos de saúde, geralmente no caso da realização de procedimentos mais caros ou não cobertos contratualmente. ${ }^{200}$

${ }^{200}$ A justificativa para o ressarcimento se baseia na idéia de que se o consumidor contratou um plano de saúde ele tem o direito de receber a assistência pela qual pagou. Se a idéia geral do ressarcimento não encontrou opositores explícitos, as divergências foram muitas quando se tratou de definir em que casos deveria ocorrer o ressarcimento (para todos os procedimentos ou só para os previstos nos contratos, ou apenas nos casos de urgência?) e de acordo com que valores ou tabelas de pagamento (tabelas do SUS ou dos planos de saúde?). 
O debate na sociedade evidenciou não apenas o conflito de interesses de consumidores e operadoras de planos, mas também a disputa entre os diferentes segmentos do mercado, particularmente entre seguradoras e medicina de grupo, e teve algumas conseqüências antes mesmo que a questão fosse discutida no Congresso. A primeira delas foi a criação, em fevereiro de 1991, do Conselho Nacional das Empresas de Medicina de Grupo (Conamge), concebido como órgão de auto-regulamentação, que pretendia minimizar a proposta de regulação governamental. Essa iniciativa expressou a reação da Abramge diante da proposta de identificar o seguro-saúde com a operação de planos de saúde, capitaneada pelas seguradoras e com o apoio da Susep. Ao mesmo tempo que buscava demarcar a especificidade da medicina de grupo como empresa voltada para a assistência à saúde, a reação da Abramge fazia coro com o movimento de desregulação das atividades econômicas que caracterizou o período.

Duas outras conseqüências expressaram o conflito de interesses entre as operadoras, de um lado, e os consumidores e a categoria médica, de outro, traduzindo-se em medidas que objetivavam ampliar o escopo da cobertura assistencial dos planos e seguros de saúde. A primeira delas foi a resolução 1.401 do Conselho Federal de Medicina (CFM), que definiu que as empresas e cooperativas que atuassem sob a forma de prestação direta ou intermediação dos serviços médico-hospitalares seriam obrigadas a garantir o atendimento a todas as doenças relacionadas no Código Internacional de Doenças da Organização Mundial da Saúde. A segunda foi uma decisão do Conselho Nacional de Seguros Privados (CNSP) que, pela resolução 31/94, criou uma apólice 'de garantia compreensiva’, que ampliava a cobertura para doenças infecciosas e limitava as exclusões de atendimento por idade, aumentando, em contrapartida, os preços para quem optasse por essa apólice.

Essas medidas expressavam os pontos mais polêmicos do debate, que se relacionavam com as restrições impostas historicamente pelos planos e seguros de saúde, as quais feriam o princípio constitucional da integralidade da assistência à saúde e se expressavam na exclusão de cobertura de patologias específicas e das 'doenças preexistentes' à contratação do plano e na restrição qualitativa ou quantitativa à realização de procedimentos diagnósticos e terapêuticos. Além dessas, outras questões eram objeto de insatisfação de 
consumidores, como a carência para utilização dos serviços, a exclusão de idosos e os reajustes de preços em razão da faixa etária. Embora legalmente inócua, a resolução do CFM mostrou a insatisfação dos médicos com as operadoras privadas e evidenciou a publicização do tema - que não se restringia apenas às instâncias judiciais e de defesa do consumidor -, o que foi decisivo para a regulamentação das atividades.

Com a grande visibilidade pública que alcançou, a regulamentação da assistência privada foi inserida na agenda do Legislativo em 1991, por meio do primeiro projeto de lei dispondo sobre obrigações e limitações dos planos de assistência médica privada, com o objetivo de discipliná-los na defesa dos interesses do usuário. Os temas contemplados nos 23 projetos de lei apresentados no período de 1991 a 1997 refletiram as questões que afloravam nos órgãos de defesa do consumidor, nas entidades médicas e na mídia, bem como os interesses das empresas operadoras de planos e seguros, também representadas no Congresso. ${ }^{201}$

\section{O debate na Câmara dos Deputados: atores e interesses}

O debate no Congresso só avançou a partir de 1994, quando a Câmara dos Deputados começou a discutir um projeto aprovado no ano anterior no Senado, desencadeando o processo da regulamentação da saúde suplementar. ${ }^{202}$ Depois de ser objeto de substitutivos na Comissão de Defesa do Consumidor e Minorias e na Comissão de Seguridade Social e Família, em 1996 foi constituída uma comissão especial para analisar e dar parecer a esse projeto

201 A proliferação de projetos de regulamentação das atividades de assistência à saúde privada expressou os diferentes interesses e concepções envolvidos, bem como a publicização que o tema alcançou. Além dos diversos anteprojetos originados no Congresso, de projetos do Poder Executivo por intermédio do Ministério da Saúde, do Conselho Nacional de Saúde e da Susep, foram apresentados durante o debate parlamentar projetos de diferentes origens, como dos órgãos de defesa do consumidor, do Ministério Público, das Unimeds etc.

202 O PL 4.425/94, originado no Senado pelo senador Iram Saraiva como PL 93/93, aprovado em 1994, é que vai ser discutido por ocasião da regulamentação, sendo apensados a ele todos os demais elaborados no período de sete anos. Esse projeto proibia a exclusão de cobertura de despesas com tratamento de determinadas doenças em contratos que assegurassem atendimento médico-hospitalar pelas empresas privadas de seguro-saúde ou assemelhadas. 
e a todas as demais propostas em tramitação na Câmara que versavam sobre planos e seguros de saúde. ${ }^{203}$

A constituição da comissão especial se deu no momento em que o Poder Executivo anunciava o envio ao Legislativo de outro projeto, elaborado no âmbito do Ministério da Saúde. Isso se dava ao mesmo tempo que a discussão se aprofundava na sociedade, expressando uma grande insatisfação com os 'abusos' dos planos de saúde, atribuídos à falta de regulamentação governamental.

A inserção do Ministério da Saúde nesse debate só vai acontecer na segunda metade da década, pois até então ele demonstrava somente a preocupação com o ressarcimento ao SUS como forma de obtenção de recursos e melhoria da gestão do sistema público. ${ }^{204}$ Essa demora traduz o isolamento do ministério em relação aos planos de saúde, que não eram objeto explícito das políticas de saúde, estas até então vistas apenas da perspectiva da construção do SUS - formalmente universal como direito. A incorporação do Ministério da Saúde se fez inicialmente pela constituição de uma comissão, em 1995, para estudar o assunto, a qual incorporou representantes dos diversos segmentos interessados, como Susep, Abramge, Ciefas, Abraspe e Unimed, além da participação da Organização Pan-Americana da Saúde (Opas). Ao se introduzir no debate, o Ministério da Saúde passou a reivindicar a fiscalização da assistência à saúde suplementar nos aspectos referentes à saúde e sua inclusão no CNSP, embora em um primeiro momento endossasse a idéia de que esse conselho deveria ser o principal locus regulador, posição que seria reformulada

$\overline{203}$ O Regimento Interno da Câmara dos Deputados prevê, em seu artigo 34, inciso II, que serão constituídas comissões especiais para dar parecer sobre proposições que versarem sobre matéria de competência de mais de três comissões permanentes que devam pronunciar-se quanto ao mérito. Esse foi considerado o caso da regulamentação da assistência médica suplementar, que envolveu questões de mérito das Comissões de Seguridade Social e Família; Economia, Indústria e Comércio; Finanças e Tributação; Defesa do Consumidor, Meio Ambiente e Minorias, além da Comissão de Constituição, Justiça e Redação, pela qual passam todos os projetos. O envolvimento de diversas comissões permanentes da Câmara dos Deputados na discussão da matéria denota as diferentes perspectivas sobre as quais a questão da saúde suplementar foi analisada: uma atividade econômica, uma perspectiva consumerista, relacionada aos direitos do consumidor que adquire um produto no mercado, e, terciariamente, uma questão ligada à saúde propriamente dita.

204 A ênfase no ressarcimento desnuda as falhas na regulação da prestação de serviços pelo SUS, pois a utilização indevida por usuários de planos de saúde, a rigor, só acontece quando eles obtêm acesso privilegiado ao sistema público, fora dos mecanismos regulares. Em princípio, se a regulação e o controle dos prestadores de serviços do SUS forem eficientes, não existe o fato gerador do ressarcimento. 
posteriormente. Dessa discussão no âmbito do Ministério da Saúde foi produzido um projeto de regulamentação, encaminhado ao Conselho Nacional de Saúde (CNS), formalmente o órgão de deliberação superior da política de saúde, até então completamente excluído do processo - o que, mais uma vez, evidencia a separação entre a assistência pública, que se considera como objeto das políticas públicas, e a assistência privada, ao que parece, vista exclusivamente como uma atividade econômica e sujeita ao Código de Defesa do Consumidor. ${ }^{205}$

Alguns indícios sugerem que a integração do Ministério da Saúde na discussão da regulação da assistência privada sinalizou uma mudança de atitude do Executivo federal em relação à política de saúde e à imagem-objetivo construída para o SUS na década anterior. Em março de 1997, o presidente da República e o ministro da Saúde lançaram o plano de ações e metas prioritárias do que foi então considerado 'o ano da saúde no Brasil'. As diretrizes políticas expressas nesse documento sugerem um redirecionamento das diretrizes básicas consagradas na Constituição, ao destacar que "a saúde (...) não pode ser uma questão exclusiva do Estado, envolvendo, necessariamente, a família e os diferentes segmentos sociais, nestes incluída a iniciativa privada" (Ministério da Saúde, 1997:3). Ao chamar atenção sobre a utilidade de parcerias com o setor privado, o documento relativizou a ênfase no papel do Estado em garantir a saúde que caracterizara todo o movimento político pela reforma sanitária e fora consagrado na Constituição. Além disso, entre as ações e metas consideradas prioritárias para melhorar a qualidade dos serviços de saúde foram incluídas a regulamentação e a fiscalização dos planos de saúde. Não apenas nesse documento, mas em outras manifestações o então ministro da Saúde colocava-se em uma posição de questionar abertamente o princípio da universalidade atrelado à gratuidade do SUS, que deveria se limitar a atender o segmento mais carente da população. Expressão dessa idéia foi o encaminhamento ao Congresso pelo governo de um projeto de emenda constitucional (PEC 32-A) suprimindo a universalidade, retirado após ter sido rejeitado pelo relator do

\footnotetext{
205 O CNS fez alterações no projeto do Ministério da Saúde e o encaminhou ao Congresso, tendo sido encampado por deputados oposicionistas em posição contrária ao projeto em tramitação. Mas o projeto do Ministério da Saúde consolidava as diferenciações dos contratos privados, visando limitar o aumento dos preços dos planos de saúde de forma a possibilitar o acesso de pessoas de renda mais baixa. Ou seja, o próprio órgão governamental encarregado da implantação do SUS se colocou na posição de buscar estimular o crescimento da assistência privada.
} 
projeto e dadas as suas poucas chances de aprovação. Mesmo que essa idéia não tenha tido continuidade, pelo menos no nível do discurso formal sinalizou uma postura diferenciada no âmbito do Poder Executivo menos de uma década após a reforma da saúde, indicando que as políticas de saúde retomavam o aparentemente interrompido caminho de solidificação de um sistema de atenção à saúde híbrido e dual, expresso pela coexistência de um discurso antiuniversalismo com a proposta de regulamentação do setor privado.

O debate parlamentar apresentou outros indícios de como a segmentação institucionalizada da assistência à saúde se traduz na percepção e na forma de compreensão da política de saúde, que também são segmentadas. Ou seja, a forma de desenvolvimento histórico da política teve conseqüências cognitivas não apenas sobre os usuários, mas também sobre os próprios formuladores de políticas. Apesar dos vasos comunicantes entre as duas formas de assistência, a interconexão entre as atividades públicas e privadas e seus efeitos negativos sobre a imagem e a eficiência do SUS não tiveram muita visibilidade no debate parlamentar nem preeminência como questão a ser considerada na política de saúde. É certo que a então bancada oposicionista do Congresso que compunha o bloco de apoiadores do sistema público universal - chamava a atenção sobre a situação que denominava de o 'parasitismo do setor privado no SUS', entendendo-se por isso várias das interconexões perversas entre os dois sistemas, como: a seletividade do atendimento ancorada na contrapartida de atendimento público universal para aqueles procedimentos não cobertos pelo sistema privado, dada a sua pouca lucratividade; a utilização privilegiada do setor público pelo usuário de planos privados, em razão das conexões entre os profissionais médicos nos dois sistemas e outras formas de acesso privilegiado ao setor público; e a privatização do sistema público, por meio do atendimento de pacientes oriundos de planos privados mediante pagamento via convênios em estabelecimentos públicos, particularmente os hospitais universitários, como forma de arrecadar recursos financeiros. Entretanto, a tônica principal do debate parlamentar ao interpretar a relação entre os dois sistemas estava na justificativa da expansão do setor privado como uma conseqüência da falência do sistema público e, ainda, na sua valorização positiva por aliviar o SUS de uma demanda que ele não conseguiria atender. Isso significa que, embora não se formalizasse o desmantelamento do SUS, a idéia 
básica expressa no desenrolar do processo decisório era fortalecer o setor privado, deixando-se o atendimento do SUS para os setores sociais impossibilitados de contratar planos ou seguros privados no mercado de saúde. ${ }^{206}$

Durante o funcionamento da Comissão Especial na Câmara dos Deputados, de forma regimental, no período de outubro de 1996 a março de 1997, foram realizadas 12 audiências públicas, quando foram ouvidos os representantes dos diferentes setores interessados, entre atores públicos e privados. ${ }^{207} \mathrm{~A}$ análise do conteúdo dos depoimentos permite traçar um panorama dos diferentes atores e respectivos interesses envolvidos e do grau de visibilidade de cada um dos que constituíam a arena política em torno da regulamentação da assistência privada.

A Abraspe e o Ciefas, como representantes das empresas com sistemas de autogestão, procuraram marcar sua condição peculiar, na medida em que a assistência é um benefício que as empresas oferecem a seus funcionários, não tendo por objeto a comercialização de planos de saúde. Por essa razão, sua pressão foi no sentido de a autogestão não ser incluída na abrangência da legislação regulamentadora, sob a ameaça de muitas empresas terem que 'devolver' a população coberta para o SUS caso tivessem que cumprir as exigências decorrentes da regulação. De acordo com seus argumentos, além de elas

206 Essas idéias, particularmente a assunção da separação entre clientelas, apareceram de forma explícita ou implícita também no âmbito governamental, como pode ser exemplificado em manifestações do então ministro de Estado Bresser Pereira em diferentes documentos redigidos à época: "O problema fundamental enfrentado pela assistência ambulatorial e hospitalar é o da baixa qualidade dos serviços. Estes não estão disponíveis para a população nem na quantidade nem na qualidade desejável. (...) Não é por outra razão que os sistemas privados de medicina de grupo - os convênios - florescem, financiados não apenas individualmente, mas principalmente, pelas empresas. A grande massa da população brasileira, entretanto, continua a depender do SUS (...)" (Bresser Pereira, 1995, transcrito em Cadernos do Mare, 1998a: 12). De forma explícita, ao defender uma reforma administrativa do SUS a justifica como forma de "garantir um atendimento infinitamente melhor para a grande maioria da população brasileira, que não tem acesso a seguros de saúde privados" (Bresser Pereira, Folha de S.Paulo, 19/1/1997, transcrito em Cadernos do Mare, 1998b: 24).

207 Foram ouvidos representantes de Abramge, Ministério da Saúde, CFM, Procon-DF, Abraspe, Asaspe-MG, Ciefas, Susep, Fenaseg, FBH, Fenam, Ministério Público, Assessoria Especial para Assuntos da Terceira Idade. As Unimeds não participaram oficialmente das audiências públicas, embora acompanhassem os debates. Essa ausência se deu por iniciativa própria, na medida em que as cooperativas defendiam a sua exclusão do escopo da regulamentação e que não seriam atingidas pela legislação, uma vez que já eram regulamentadas pela legislação referente às cooperativas. "A UNIMED achava que iria fazer prevalecer junto ao governo essa postura e que não seria abrangida pela lei. Isso foi um erro estratégico muito grande, porque se a UNIMED tivesse participado desse processo desde o início, essa lei teria saído diferente" (entrevista com Virgílio Baião, presidente da Asaspe-MG, realizada em julho de 2002). 
não comercializarem planos, a autogestão se distinguiria pelo fato de as coberturas serem definidas em razão das possibilidades das empresas e de seus empregados, fazendo parte, muitas vezes, de acordos salariais. Por integrar o contrato de trabalho, a assistência médica se sujeita ao controle pelo Ministério do Trabalho, no caso dos planos coletivos. Além de ressaltar sua especificidade, os representantes da autogestão reivindicavam incentivos governamentais ao setor pela redução de contribuições sociais como forma de desenvolver os planos de saúde empresariais. ${ }^{208}$

Se a posição dos sistemas de autogestão, bem como das cooperativas médicas, era no sentido de não serem abrangidos pela lei regulamentadora, a medicina de grupo se posicionou pela defesa da auto-regulação. Representadas pela Abramge, as empresas de medicina de grupo defendiam o direito de a iniciativa privada atuar na saúde da forma que julgasse conveniente, na condição de sistema supletivo, isto é, não vinculado ao sistema público. Para isso, avocava a liberdade à iniciativa privada na assistência à saúde garantida pela Constituição. Defendia ainda a liberdade de escolha das pessoas para optar pelo sistema público ou privado, nesse último caso tendo um desconto na sua contribuição à seguridade social, tal como no passado as empresas recebiam um subsídio governamental sob a forma de devolução de recursos pagos à Previdência Social para se incumbirem da assistência médica para seus empregados. A posição contra a regulamentação governamental encontrava eco entre parlamentares que consideravam que apenas no caso de o governo conceder subsídios aos planos se justificaria a regulamentação, que, caso contrário, deveria ficar a cargo do próprio mercado. Para organizar a atividade e garantir o mercado, a Abramge admitia uma regulamentação, mas desde que não interferisse na relação contratual entre empresa e usuário, sendo contrária, portanto, à definição de cobertura e preços dos produtos a serem oferecidos no mercado de saúde.

A posição dos prestadores de serviços também não foi uniforme. A categoria médica, representada pelo Conselho Federal de Medicina (CFM), repudiava qualquer mecanismo de exclusão de procedimentos ou discriminação para o acesso à assistência privada. Na defesa de sua posição, também se

\footnotetext{
208 Essa idéia chegou a ser proposta em um projeto de lei de autoria do deputado Genésio Bernardino,
} que, entretanto, provocou fortes resistências, não tendo sido votado. 
remetia aos dispositivos constitucionais que garantem a integralidade da assistência de forma igualitária. Nessa perspectiva, seja por ideologia, seja por interesses corporativos, a posição do CFM se alinhou às reivindicações dos usuários ao se mostrar contrariamente às restrições de cobertura, à carência e à limitação de procedimentos. Curiosamente, tanto entre os usuários de planos privados quanto entre a categoria médica, operava-se uma imbricação entre a noção de saúde como um direito constitucional e a assistência privada. De certa forma, no seu posicionamento está implícita a idéia de uma transposição da garantia desses direitos constitucionais à sua prestação na esfera privada, embora nem a Constituição nem a regulamentação tenham tratado de definir os mecanismos de articulação entre o segmento público e o privado nessa perspectiva de garantia do acesso universal e igualitário, os quais foram sempre tratados como dois segmentos independentes. O CFM propôs também o credenciamento universal dos profissionais, garantindo assim a livre escolha pelo usuário, um dos princípios defendidos pela categoria médica e que é limitado pelo sistema de credenciamento de médicos utilizado pelas operadoras. O CFM manifestou também posição contrária à possibilidade de renúncia fiscal, mediante a dedução dos gastos com planos de saúde da renda tributável para fins de pagamento do Imposto de Renda, sob a alegação de que desviava recursos que poderiam ir para o SUS, embora aparentemente possa revelar muito mais uma posição corporativa, uma vez que esse mecanismo dificulta a sonegação por parte dos médicos. Apesar da relevância dessa questão, ela não foi contemplada na legislação nem ao menos discutida, o que também é um indício da intenção governamental de incentivar a atividade privada.

A FBH, representando os prestadores hospitalares, defendia uma regulamentação menos abrangente e que buscasse apenas garantir a capacidade operacional do sistema privado, mas que levasse em conta a capacidade de pagamento dos consumidores. Em outras palavras, sua preferência era no sentido de se garantir a segmentação do mercado em razão do poder de compra e a explicitação contratual das restrições e dos reajustes. A proliferação de operadoras de planos de saúde sem nenhum controle tinha configurado um mercado no qual proliferavam empresas pouco sólidas e incapazes de honrar os compromissos contratuais e, conseqüentemente, os financeiros com os prestadores de serviços. Quanto aos procedimentos mais complexos e de 
maior custo, que, em geral, eram excluídos da cobertura dos planos e seguros de saúde, a FBH defendia uma solidarização no setor privado, no sentido da constituição de fundos comuns para custear esses procedimentos, tornando-os viáveis economicamente e baixando seus custos. Dessa forma, seriam carreados para o setor privado esses procedimentos, o que, sem dúvida, seria de interesse dos prestadores de serviço ao ampliar a demanda em razão dos convênios e seguros privados.

A posição da área econômica do governo, representada pela Susep, era centrada na defesa da participação de capital estrangeiro no setor de seguro de saúde, no tratamento igual a seguradoras e planos de saúde, exceto a autogestão, e na definição da Susep como órgão fiscalizador do setor. De acordo com uma primeira interpretação da Constituição, a participação de capital estrangeiro estaria vedada, a menos que houvesse declaração de interesse nacional. Embora uma segunda interpretação tenha restringido essa proibição ao setor financeiro, a Susep reforçava a questão, alegando como de interesse nacional para o aumento da concorrência no setor. O tratamento igual aos diversos segmentos incluía, principalmente, a extensão aos planos de saúde da exigência de prova de capacitação financeira, o que diz respeito às reservas e ao capital necessários, até então exigidos apenas das seguradoras com a fiscalização da Susep. Secundariamente, reivindicava a manutenção da prática das seguradoras de trabalhar com uma cadeia de médicos referenciados. ${ }^{209}$ Em relação ao locus regulatório, a posição da Susep era de reservar a ela a competência de órgão fiscalizador também dos planos de saúde, garantindo-se a participação do Ministério da Saúde apenas na avaliação da prestação dos serviços. E defendia que o Conselho Nacional de Seguros Privados, na qualidade de órgão regulador da atividade, fosse formado apenas por representantes do Poder Executivo, garantindo-se a participação do setor privado e da sociedade apenas em comissões de caráter consultivo. Embora com um discurso conciliador, posicionava-se na prática pela manutenção das exclusões de procedimentos e patologias, no que se alinhava aos interesses do conjunto das operadoras de planos de saúde.

209 Esse ponto era bastante polêmico, na medida em que a principal distinção da seguradora a um plano de saúde era considerada o pagamento de despesas de saúde no limite do valor da apólice, sendo que o segurado tem direto à livre escolha do prestador de serviço. No caso de referenciamento de prestadores, a seguradora pode efetuar o pagamento diretamente ao prestador, o que na prática a aproxima do plano de saúde, que atua com uma rede de credenciados. 
As discussões na Câmara dos Deputados evidenciaram que o projeto de regulamentação tinha um duplo escopo. Por um lado, tratava de disciplinar as relações contratuais entre as seguradoras, empresas de medicina de grupo, cooperativas médicas e planos de autogestão e seus usuários, regulando cláusulas contratuais, principalmente as relativas a exclusões de cobertura assistencial. Por outro lado, a legislação se propunha a regular o setor de saúde suplementar, fixando exigências para a constituição e o funcionamento das operadoras de planos e seguros de saúde, e definindo seus órgãos fiscalizadores, buscando garantir sua capacidade econômico-financeira. Se nesse aspecto a regulamentação governamental era admitida pelos diferentes segmentos, mesmo que em diferentes níveis ou de pontos de vista diversos, o mesmo não acontecia em relação à regulamentação dos conteúdos dos contratos, que encontrou resistências das operadoras diante do que consideravam uma intromissão indesejável no mercado e no direito à livre escolha dos consumidores. Essa posição teve o apoio de parte do governo, por intermédio da Susep, além dos representantes dos hospitais. E, nesse aspecto, configurava-se o conflito entre a noção de saúde como direito versus a livre concorrência na produção da assistência à saúde. Se como direito a integralidade da assistência é um princípio, na oferta pelo mercado essa noção é subordinada à lógica mercantil da produção de serviços em um mercado em que, pelo lado dos produtores, prevalece a seleção de riscos, com o objetivo de diminuir custos, e, pelo lado dos compradores, a escolha definida em razão da disponibilidade financeira.

Esse conflito em torno da compatibilização dos preceitos constitucionais relativos à garantia da universalidade, integralidade e igualdade no acesso a serviços de saúde, de um lado, e as formas privadas de provisão dessa assistência, de outro, pode ser exemplificado com o confronto entre a posição de um representante do Ministério Público e a de um parlamentar, representante das seguradoras. O primeiro, subprocurador-geral da República e coordenador da $7^{\mathrm{a}}$ Câmara do Ministério Público Federal, Miguel Guskow, defendia:

A norma constitucional, no que se refere à assistência à saúde, é óbvia: é objeto de relevância pública. Como essa dimensão qualitativa é prevalecente sobre as vontades privadas, regras devem ser desde logo fixadas para que o objeto de relevância pública não se torne fonte de especulação, mas entre no mundo negocial mediante contornos definidos e inflexíveis. (...) Que proteção se deveria dar ao consumidor do plano de 
saúde? Preliminarmente, por questões óbvias, as cláusulas de exclusão ou restritivas a determinadas patologias devem presumir-se não escritas. (...) O bem em questão, saúde, é universal e não comporta, para efeito de sua proteção no plano de saúde, o fracionamento. (...) Por integralidade se entende a vedação ou restrição de patologias do elenco de doenças a ser atendido como prestação contratual, a proibição de 'plano de saúde' apenas ambulatorial ou apenas hospitalar, porque não se pode, para efeitos normativos, ser tido como tal. Será outro tipo de prestação de serviços, mas não esse, universal, com os contornos constitucionais. Por continuidade entende-se que, se o segurado não adimplir por até seis meses o pagamento, terá o seu 'plano de saúde' assegurado; assim como, se houver extinção ou falência da empresa contratante, seus direitos serão preservados, sem ônus de adesão a outra empresa ou a outro plano. Carências são vedadas porque são estímulos à capitalização não autorizada, em detrimento do consumidor. (Audiência Pública realizada em 12/3/1997)

O que deve fazer o legislador ordinário? Disciplinar a matéria a partir de normas gerais, de modo que atenda aos princípios constitucionais. (...) Ele não deve se preocupar em assegurar o lucro ao setor privado, porque isso não é sua função diante do termo em pauta. A assistência à saúde deve ser integral, porque a saúde é um bem indivisível. O conceito constitucional da saúde, art. 196, é globalizante e sua execução cabe tanto ao Poder Público quanto ao setor privado. (Audiência Pública realizada em 18/3/1997)

Posicionando-se contra qualquer forma de regulamentação, o deputado Ayres da Cunha, com vínculos estreitos com o setor de seguros de saúde, refutava:

Vemos que toda vez que o Estado se propõe a regulamentar alguma coisa é um desastre. (...) V. Exa. disse que um plano de saúde é um contrato de adesão. Em todo contrato de adesão, quem adere não pode mudar cláusula. Duvido que V. Exa. algum dia tenha mudado a cláusula de um contrato referente a cartão de crédito; ou que, quando da abertura de uma conta bancária, tenha discutido as cláusulas que vão reger o relacionamento entre V. Exa. e o banco. (...) se todas as premissas que V. Exa. citou são erradas, conforme meu ponto de vista, evidentemente V. Exa. chega a uma conclusão errada. (...) Dizer que não pode haver carência é uma ingenuidade, mostra que a pessoa não tem a menor visão de como funciona um plano ou um seguro-saúde. Dizer também que a cobertura têm que ser universal é um absurdo! Veja só. Tenho uma vida sexual regular e não uso drogas. Para que quero ter cobertura 
para a Aids? Por que vou encarecer meu plano de saúde, querendo ter cobertura para a Aids? Fiz vasectomia, e minha mulher já passou da idade de procriar. Para que quero cobertura para obstetrícia? Toda a minha família tem integridade mental. Nenhum membro da família precisa de psiquiatra. Para que internação psiquiátrica? (...) O que sinto é o seguinte: no nosso País, para qualquer atividade que começa a se destacar, a ir bem, aparece logo o Governo para destruir. Por quê? Porque não podemos ter nada na nossa sociedade que funcione bem. Não podemos ter nada que dê lucro honestamente. Por quê? Porque isso vai destacar-se das outras atividades e vai mostrar que o Estado é um mau gerenciador. (Audiência Pública realizada em 12/3/1997)

Sob a pressão da mídia e do governo federal, que ameaçava assumir o comando e editar Medida Provisória regulamentando a questão, a Comissão não emitiu parecer conclusivo no prazo regimental, e a matéria foi avocada ao Plenário, conforme previsto no artigo 52, parágrafo $6^{\circ}$, do Regimento Interno da Câmara dos Deputados. ${ }^{210} \mathrm{Na}$ tentativa de obter os entendimentos necessários à elaboração de um substitutivo que alcançasse algum consenso, foi formada uma comissão informal com representantes dos diversos setores envolvidos, tanto empresas do setor como representantes de usuários e das entidades de defesa do consumidor e parlamentares designados pelos líderes de todos os partidos. Sob forte pressão do Executivo, foi produzido um relatório negociado e acolhido pelo relator, o deputado Pinheiro Landim, do PMDB.

Finalmente, em outubro de 1997, é apresentado em plenário o projeto substitutivo do relator, que, segundo ele, buscava conciliar os interesses do consumidor com a viabilidade econômica e o desenvolvimento do mercado de planos e seguros de saúde. ${ }^{211} \mathrm{O}$ projeto traduzia, em linhas gerais, parte das demandas dos usuários, mas também a pressão dos interesses empresariais do setor voltados para a lucratividade, na maior parte das vezes incompatível com a demanda por cobertura ampla. Por parte do Executivo e sua base parlamentar, evidenciou-se claramente o objetivo de estimular o desenvolvi-

${ }_{210}$ Pereira, Costa e Giovanella (2001) destacam alguns pontos de conflito que impediram que o relator da Comissão submetesse um texto minimamente consensual ao plenário: a participação muito baixa dos movimentos sindical e sanitário no debate, a ausência de atuação unificada das seguradoras e operadoras de planos de saúde e uma ação coletiva frágil dos consumidores.

211 De acordo com o relator, “à defesa intransigente dos interesses do consumidor soma-se o cuidado em preservar a viabilidade econômica e respeitar as bases técnicas sobre as quais se assenta o setor" (Diário da Câmara dos Deputados, quarta-feira, 8/10/1997: 31.606). 
mento desse mercado, atraindo, inclusive, o capital estrangeiro. Curiosamente, esse processo se desenvolvia ao mesmo tempo que, paralelamente e de forma independente, crescia a mobilização por maior aporte de recursos ao SUS, com vistas a possibilitá-lo a cumprir seus objetivos constitucionais, que teve o apoio explícito do governo federal, conforme visto anteriormente. A dualidade estrutural do sistema de atenção à saúde se expressava também na forma isolada de encaminhamento das duas ordens de questões: o financiamento do sistema público e a regulamentação do sistema privado.

\section{A discussão do projeto substitutivo: idéias e resultados}

O debate do projeto substitutivo no plenário da Câmara é revelador das idéias construídas em torno da assistência à saúde. De algum modo, tal como ocorrera durante o processo constituinte, ele é revelador do conflito entre as duas concepções de assistência à saúde que conviveram na trajetória da política de saúde: a publicista e a privatista. Diferentemente, contudo, nesse momento ambas já se encontravam ancoradas em fortes estruturas institucionais e apoiadas por interesses políticos já bastante consolidados. Por um lado, o sistema público, apesar de todas as dificuldades políticas e econômicas, institucionalizava-se pela via de um arcabouço jurídico que se consolidava e induzia a práticas transformadoras, por meio de um processo radical de descentralização da política de saúde. Nesse processo, um espectro amplo de atores políticos se constituía ou se fortalecia ao ser inserido na implantação do SUS, ressaltando-se os governos municipais, que assumiam a execução da assistência à saúde em graus variados, e a participação da sociedade, por intermédio de vários segmentos representados nas instâncias de controle público formalmente criadas, destacando-se os conselhos paritários de caráter deliberativo e fiscalizador. ${ }^{212}$ Por sua vez, a estrutura de assistência privada já se institucionalizara o suficiente para desafiar a implantação dos preceitos universalistas e igualitários. Constituíra atores políticos relevantes e atuantes na defesa de seus interesses, além de fazer parte do imaginário dos usuários da assistência à saúde, muito mais do

212 Criados para as várias instâncias de governo por determinação legal, os conselhos de saúde têm contribuído para a constituição de novos sujeitos políticos, malgrado as diferenças locais e regionais em razão da dependência de outros fatores políticos, particularmente a forma de constituição do poder local e o grau de mobilização da sociedade civil. 
que a assistência pública. Isso se expressa na imagem do setor público como ineficiente, de má qualidade e deteriorado, vis-à-vis à imagem do atendimento privado como de melhor qualidade, apesar das distorções de cobertura e preços que se buscava solucionar com a proposta de regulamentação governamental. Essas duas estruturas de assistência à saúde expressavam-se em concepções ambivalentes, em que à perspectiva de direito social a ser garantido com base em ações diretas do Estado se mesclava a de direitos de consumidor, que pressupunha a garantia de contratos e da qualidade dos serviços contratados no mercado.

Por parte dos partidos oposicionistas, particularmente dos partidos de esquerda, o projeto substitutivo recebeu duras críticas diante do que era considerado como a privatização da saúde, transformando-a em uma mercadoria a que tem acesso apenas quem tem recursos para comprá-la, em franca oposição às disposições constitucionais, que proclamam, além da universalidade, a igualdade no atendimento à saúde. As clivagens ideológicas em torno do eixo estatização/privatização que se manifestaram durante a tramitação do projeto de regulamentação do setor privado explicitam, de algum modo, o conflito entre a concepção de saúde como um direito - que remete ao seu caráter público e à noção de universalidade - ou como um bem privado a ser garantido por meio de trocas no mercado, portanto, relacionado à busca da maximização dos ganhos de quem oferece o serviço e dependente da disponibilidade de recursos de quem compra. O embate tanto no Congresso como na sociedade, em uma perspectiva analítica, permite elucidar as dificuldades decorrentes do tratamento da assistência à saúde como um bem privado e traçar os elementos do conflito em razão da incompatibilidade no campo da assistência à saúde entre a lucratividade empresarial e as demandas por integralidade e igualdade da atenção. Apesar de muitos dos segmentos verem na regulamentação a possibilidade de conciliar a lógica de mercado com a garantia de direitos, essa incompatibilidade não tinha grande visibilidade.

As ambigüidades de um sistema de assistência à saúde de caráter dual se expressaram nos vários discursos, de tal forma que ora se via o sistema privado como uma alternativa independente do SUS, que tem uma lógica mercantil e não social, ora se considerava a peculiaridade do mercado de assistência à saúde, na medida em que o assalariado de classe média é coagido a buscar a 
assistência suplementar não como uma opção, mas como uma necessidade, em razão da má qualidade dos serviços públicos. ${ }^{213} \mathrm{~A}$ idéia mais recorrente, implícita no debate no Congresso, que justificava a defesa do sistema suplementar era a percepção de que segmentação de clientelas nos dois sistemas de assistência seria favorável ao SUS ao tornar seus recursos mais produtivos, uma vez que dirigidos a uma população usuária menor, ao ser desafogado pelo sistema privado. É nessa perspectiva de regular o mercado para desenvolvê-lo, de forma a aumentar a cobertura, que se insere a proposta de participação de empresas estrangeiras como forma de redução de custos ao tornar o mercado mais competitivo. ${ }^{214}$

Expressão da incompatibilidade da garantia de direitos amplos e da lógica mercantil, os pontos mais polêmicos do projeto foram os aspectos relativos à regulamentação dos contratos. Apesar de responder a algumas das demandas dos consumidores, estabelecendo coberturas mínimas e proibindo algumas exclusões antes praticadas rotineiramente, o substitutivo do relator manteve limitações e carências, garantiu reajustes em virtude da faixa etária e permitiu planos parciais. ${ }^{215}$ Desta maneira, concretizou-se nesse projeto a diferenciação da assistência com base no poder de compra dos consumidores em um mercado

213 Essa visão está implícita, por exemplo, entre os representantes dos consumidores que justificavam a necessidade de regulamentação pelo Poder Público no sentido de garantir no sistema privado a assistência integral como direito (idéia presente em depoimento da representante do Procon-DF em audiência pública na Câmara dos Deputados em 29/10/1996).

214 O discurso do deputado federal pelo PSDB-RJ (então o partido governista) Ronaldo Cezar Coelho em defesa do projeto demonstra bem a concepção de sistema de saúde subjacente em que se visualiza uma 'integração' entre o sistema público e o privado, entendida na perspectiva de que quanto maior a saúde suplementar, maiores as garantias e a qualidade dos serviços universais do SUS.

215 As questões mais polêmicas e que não lograram a obtenção de consenso foram: a possibilidade de discriminação de doenças (entre elas as preexistentes à contratação dos planos), de doentes e de procedimentos, vista pelos opositores como a legalização da exclusão; a possibilidade de planos parciais (ambulatoriais ou hospitalares) ferindo a idéia de integralidade da assistência; e a variação de preços em virtude da faixa etária. Como solução conciliadora diante dos clamores contra as restrições impostas pelos planos de saúde, o projeto estabeleceu um 'plano de referência' com atenção integral, que deveria ser oferecido por todas as operadoras, mas com preço diferenciado, além do 'plano mínimo', que definia o pacote assistencial mínimo, que deveria ser coberto por qualquer plano. 
como qualquer outro, o que deixou insatisfeitos consumidores e profissionais, provocando também a reação das operadoras em sentido contrário. ${ }^{216}$

Nos aspectos relativos à regulamentação do setor, os principais conflitos foram a definição do órgão fiscalizador e o tratamento igual dado às diferentes operadoras de planos e seguros, incluindo a chamada autogestão. Pelo substitutivo do deputado Pinheiro Landim, posteriormente aprovado, foi definido o CNSP como o locus institucional da regulação, inclusive nos aspectos relativos à saúde, estabelecendo-se alterações na sua composição, de forma a incluir o Ministério da Saúde. A fiscalização coube ao Ministério da Fazenda, por meio da Susep, expressando a ótica econômica da qual partira a regulamentação da atividade, tendo como base conceitual o modelo de regulação econômica. Na relação com o sistema público, o único dispositivo do projeto era a exigência de ressarcimento ao SUS nos casos de utilização dos serviços públicos por contratantes de planos de saúde privados.

Houve certo consenso entre os parlamentares, inclusive os da oposição, de que a modalidade de autogestão merecia um tratamento diferenciado, na medida em que não se constitui como empresa lucrativa, mas como uma assistência prestada pela empresa empregadora a seus funcionários. No debate parlamentar, verificou-se, mesmo entre os defensores de teses mais publicistas, certa complacência com referência aos planos de autogestão, aparentemente em contradição com a defesa de uma assistência pública universal, na medida em que a autogestão também é uma segmentação em relação ao SUS e, por

$\overline{216}$ Com uma postura realista e assumindo como legítima a segmentação dentro mesmo do setor privado, assim se expressou o deputado Inocêncio Oliveira (PFL-PE): “já que o SUS não está atendendo adequadamente nossa população, sobretudo os segmentos mais pobres, carentes e necessitados, os planos de saúde surgem, sem sombra de dúvida, como nova opção. (...) a criação de um plano de referência com cobertura total para o segmento que pode pagar bem é uma condição fundamental. No entanto, um plano mínimo para a população que não pode pagar muito é também da mais alta importância, é realista, com relação à situação brasileira (...)" (Diário da Câmara dos Deputados, 15/10/1997: 32.454). Expressou ainda de forma clara a idéia que permanecia subjacente no debate, que é a divisão de atribuições entre o setor público e o privado, cabendo ao Ministério da Saúde fazer 'a verdadeira medicina preventiva' e atender aos quarenta milhões de excluídos. Na mesma linha, contra a cobertura integral defendida pela oposição e pelos consumidores, assim se pronunciou o deputado Roberto Jefferson (PTB): "cobertura única é sinônimo de sistema único. O SUS faliu e agora temos que salvar alguma coisa nos seguros e medicina de grupo. Medicina única, procedimento único: falência do sistema público. Agora estamos fazendo uma lei, longe daqueles chavões da constituinte 'saúde é um direito de todos e um dever do estado' e o Estado não cumpre por ser uma utopia” (Diário da Câmara dos Deputados, 16/10/1998: 32.712). 
cobrir os trabalhadores em geral mais organizados, retira do sistema público importantes bases de apoio. Em certa medida, essa postura dos parlamentares vinculados ideologicamente aos interesses dos trabalhadores e dos excluídos mostra mais uma evidência das contradições nas atitudes em relação à assistência médica empresarial que dá cobertura a um expressivo contingente de trabalhadores e passa a ser vista por esses como uma conquista, e não como uma forma de privatização da assistência.

Embora tenham sido apresentadas 131 emendas ao substitutivo do relator, apenas algumas foram aprovadas, as quais não mudavam a essência do projeto, evidenciando o acordo com a base governista no sentido de apoiar o projeto do governo. Depois de aprovado na Câmara em dezembro de 1997, o projeto foi encaminhado para votação em segundo turno no Senado. Em síntese, o conteúdo desse projeto era:

A base conceitual do projeto aprovado na Câmara é o da macro-regulação [sic], expresso em dois grandes eixos, um de natureza econômica e outro focado na assistência à saúde. $\mathrm{Na}$ regulação da atividade econômica (...) definia as condições de ingresso, operação e saída do setor e um conjunto de exigências de garantias financeiras e econômicas, inclusive margem de solvência, das empresas que operam no setor. Esse conjunto de regras pretendia dar segurança ao consumidor, garantindo que as empresas teriam que demonstrar condições efetivas de cumprir os contratos assinados. (Januário Montone, diretor-presidente da ANS, 2001)

Na regulação da assistência à saúde, houve a exigência de que todas as operadoras de planos de saúde demonstrassem a capacidade de produzir serviços integrais de assistência à saúde, o que se expressava na exigência de um 'plano de referência'. Mas, por sua própria opção, o consumidor poderia adquirir um plano com cobertura menor, desde que não inferior ao definido como um 'plano básico'.

\section{A reviravolta no Senado: a mudança da atuação do Ministério da Saúde}

O projeto aprovado na Câmara provocou insatisfação de diferentes segmentos, excetuando-se a medicina de grupo, as seguradoras e os planos de autogestão, que pelo menos em certa medida tiveram seus interesses contem- 
plados. ${ }^{217}$ Entidades representativas dos usuários, como o Instituto Brasileiro de Defesa do Consumidor (Idec), órgãos de Proteção e Defesa do Consumidor (Procon) e de profissionais de saúde, como o CFM e a AMB, manifestaram-se publicamente contra o projeto de lei tanto na Câmara quanto no Senado. Realizaram atos públicos e fizeram divulgação na imprensa e muita pressão sobre deputados e senadores. Os principais questionamentos ao projeto relacionavam-se à manutenção de restrições de cobertura e à definição da Susep como órgão fiscalizador. O Senado mostrou ser uma arena mais permeável aos interesses das entidades médicas e das Unimeds (Bahia, 1999). O embate entre os atores e as posições divergentes indicava a não-aprovação do projeto no Senado. Caso isso acontecesse e ele recebesse emendas propositivas no Senado, teria que voltar para a Câmara, reiniciando o processo de discussão. Do ponto de vista regimental, a única hipótese de isso não ocorrer seria no caso de o Senado fazer apenas emendas supressivas.

Em 1998, o então nomeado ministro da Saúde, José Serra, empenhou-se em negociar o projeto no Senado, de tal forma que, diferentemente do período anterior, o setor saúde passou a definir o processo decisório. A nomeação de José Serra significou a inserção do Ministério da Saúde no núcleo do poder, iniciando uma fase nova do ministério. Especificamente no caso da assistência privada, a mudança ministerial marca uma inflexão na atuação do ministério, deixando-se de considerar a questão como afeita à área privada e econômica, passando-se a considerá-la como da competência do Ministério da Saúde. A defesa urgente da regulação passa a ser feita com base em um discurso econômico sobre a imperfeição do mercado no caso da assistência médica, em que certas premissas básicas do mercado eficiente não funcionam. Com a mudança ministerial e após sete anos de debate sobre a questão, foram reconfigurados os objetivos da regulação governamental da assistência suplementar da perspectiva do Poder Executivo, que passa a se empenhar fortemente na regulação do setor.

217 Conforme entrevista com João Luís Barroca de Andréa, diretor de Normas e Habilitação dos Produtos da ANS, realizada em maio de 2001: "Esse projeto, do jeito que saiu, era tolerável pela medicina de grupo, tolerável pelas autogestões, bastante bom para as seguradoras e bastante ruim para as cooperativas; mas não atendia aos principais desejos das entidades de defesa do consumidor e também das entidades médicas, que começam a fazer ruído quando esse projeto volta ao Senado para ser sacramentado em 1998." 
Esses objetivos foram posteriormente sintetizados assim: "A regulação de planos e seguros de saúde é uma atividade governamental destinada a corrigir as falhas de mercado e condições contratuais que afetam consumidores e empresas e repercutem negativamente na opinião pública" (Barroca de Andréa, 2002: 4). Apesar da ênfase nos aspectos assistenciais, a interferência governamental foi justificada como forma de buscar um equilíbrio entre os agentes do mercado consumidores, operadoras e prestadores de serviço - e o SUS, criando condições para o crescimento do setor e a garantia da prevalência do interesse público (Montone, 2000). ${ }^{218}$

Por intermédio do ministro, o governo defendeu a aprovação imediata do projeto, apenas com emendas supressivas, e foi firmado um acordo com os senadores e também com os órgãos de defesa dos consumidores e os profissionais de saúde, segundo o qual, por meio de medida provisória, o Executivo alteraria os pontos divergentes em que não fora possível conciliar os interesses em disputa. ${ }^{219}$

Em maio do mesmo ano, o Senado aprovou com supressões o projeto de lei da Câmara, dando origem à lei 9.665. Apenas dois dias após ser sancionada pelo presidente da República, foi editada a medida provisória 1.685 (5/6/1998), contendo as mudanças acordadas pelo ministro, em um procedimento que, embora legal, subverte o processo legislativo usual e mostra a

${ }^{218}$ Em outra palestra, o diretor-presidente da ANS resume os objetivos da regulamentação em seis pontos: 1) assegurar aos consumidores de planos privados de assistência à saúde cobertura assistencial integral e regular as condições de acesso; 2) definir e controlar as condições de ingresso, operação e saída das empresas e entidades que operam no setor; 3) definir e implantar mecanismos de garantias assistenciais e financeiras que assegurem a continuidade da prestação de serviços de assistência à saúde contratados pelos consumidores; 4) tornar transparente e garantir a integração do setor de saúde suplementar ao SUS e o ressarcimento dos gastos gerados por usuários de planos privados de assistência à saúde no sistema público; 5) estabelecer mecanismos de controle da abusividade de preços; 6) definir o sistema de regulamentação, normatização e fiscalização do setor de saúde suplementar (Montone, palestra proferida no Conselho Nacional de Saúde, em 6/6/2001).

${ }^{219}$ O acordo proposto previa: a ampliação de cobertura por meio de planos segmentados por regime assistencial (ambulatorial ou hospitalar, dependendo do contrato); o compromisso de revisão da exclusão de transplantes de órgãos; nova redação para o aumento de preço para pessoas acima de 60 anos; compromisso de revisão dos termos para cobertura de doenças e lesões preexistentes; definição do Ministério da Saúde como instituição responsável pela regulamentação dos aspectos assistenciais e da Susep pelos aspectos econômico-financeiros, com poder de veto recíproco (Bahia, 1999). 
força do Poder Executivo no processo decisório e como Poder Legislativo. ${ }^{220}$ Do ponto de vista da regulação, houve uma mudança substancial ao se alterar o locus regulatório, criando-se um sistema híbrido, que agregava a área financeira e a assistencial. Cria-se o Conselho Nacional de Saúde Suplementar (Consu), presidido pelo ministro da Saúde, expressando a prioridade do Ministério da Saúde na normatização do setor, mantendo-se o papel regulador do CNSP nos aspectos econômico-financeiros. Como braços operacionais dos dois conselhos, permanecem o Departamento de Saúde Suplementar, recentemente criado no âmbito do Ministério da Saúde, e a Susep no Ministério da Fazenda. Dá-se também a alteração da Câmara de Saúde Suplementar, que passa a ser uma instância consultiva, com uma composição ampliada e com representação dos diferentes segmentos e interesses envolvidos. Em relação aos aspectos assistenciais, as mudanças foram significativas, no sentido de coibir a prática empresarial da seleção de riscos.

A partir daí, a regulação sai do Legislativo, e o Executivo assume a condução do processo regulatório por meio da edição e reedição de sucessivas medidas provisórias. Ao todo, foram editadas $44 \mathrm{MPs}$, sendo a última a de $\mathrm{n}^{\circ}$ 2.177-44, em agosto de 2001, ainda em vigor. ${ }^{221}$ O processo de regulamentação vem se consolidando por resoluções do Consu e, a partir de 1999, da Agência Nacional de Saúde Suplementar (ANS). As principais mudanças no percurso das 44 MPs foram relativas ao modelo de regulação. Atualmente, o marco regulatório encontra-se estabilizado. Apesar da necessidade de consolidar a legislação regulamentadora e legitimá-la na instância legislativa parlamentar, a votação de um projeto de lei de conversão que reflita o modelo de regulação vigente ainda não está na pauta do Congresso, em grande parte pelo caráter ainda bastante polêmico da questão, mas também pelas atribuições legislativas assumidas pela agência reguladora.

${ }^{220}$ A MP causou grande insatisfação do setor da medicina de grupo, assim expresso pelo presidente da Abramge-MG, José Fernando Rossi, em entrevista concedida em outubro de 2002: "Essa medida foi completamente diferente do que a gente queria, do que tinha sido acordado anteriormente. Nas comissões que discutiram o projeto de lei não se conseguia chegar a um consenso mas se conseguiu alinhavar um projeto que poderia atender. Um abria mão de um detalhe, o outro abria mão de outro, e cada segmento ia se adequando; e naquela mesa saiu o projeto que seria transformado em lei. Mas na realidade o ministro da Saúde reagiu de outra forma, ignorou aquilo e fez a MP.”

221 As mudanças nas regras congressuais deixaram de obrigar a reedição de medidas provisórias decorrido o prazo de trinta dias, quando perdiam a validade. 


\section{A Evolução do Processo Regulatório: a mudança do modelo institucional}

A evolução da regulamentação da assistência à saúde suplementar revela mudanças de concepções que se traduziram em alterações no modelo de regulação. A primeira medida provisória que alterou a lei 9.656/98 após o debate no Senado constituiu uma regulamentação bipartite, em razão de uma separação de funções entre duas instituições. Em relação ao primeiro projeto aprovado na Câmara, essa mudança indica uma alteração conceitual ao se ampliar a regulamentação da assistência à saúde, mudando-se da idéia de uma macrorregulação econômica para o conceito de regulação específica. A conseqüência foi o reforço do papel da área da saúde, sendo que o Ministério da Saúde passa a ter papel equivalente ao do Ministério da Fazenda, mantendo-se, contudo, a compreensão de assistência como um produto a ser oferecido ao consumidor.

O modelo híbrido de regulação logo mostrou suas dificuldades de operacionalização e de compatibilização e problemas de superposição de funções. Ao passo que o Consu de pronto se pôs a funcionar, aprovando um conjunto de resoluções voltadas ao detalhamento das regras para cumprimento da legislação, o mesmo não ocorreu no CNSP. ${ }^{222} \mathrm{Em}$ conseqüência, foi feita nova alteração institucional por meio de medida provisória no sentido de se restringir ao Consu a atribuição de órgão regulador, o qual, entretanto, deixa de ser vinculado ao Ministério da Saúde e passa a ser um órgão interministerial, ligado à Casa Civil em um primeiro momento. ${ }^{223} \mathrm{O}$ Consu passa a ser o órgão máximo de deliberação, mas ao mesmo tempo define-se no âmbito do Executivo a criação de uma agência reguladora.

222 De acordo com o presidente da ANS: "O ineditismo do processo, aliado à separação entre a regulamentação e fiscalização econômico-financeira, que ficou na área da Fazenda, e à regulamentação e fiscalização da produção dos serviços de assistência à saúde, atribuição do Ministério da Saúde, dificultou a sinergia e provocou uma falta de unidade estratégica no processo de regulação, gerando problemas de efetividade, habilmente explorada por uma parcela do mercado" (Januário Montone, 6/6/2001).

223 De acordo com entrevista realizada com João Luís Barroca de Andréa (2001), diretor da ANS, a vinculação do Consu à Casa Civil, sendo ele presidido pelo ministro-chefe da Casa Civil, "foi uma solução de compromisso para que não ficasse como se fosse uma vitória de um ministro sobre o outro". A composição do Consu sofreu várias alterações, atualmente sendo presidido pelo ministro da Justiça, e não contando mais com a participação da Casa Civil. Além do ministro da Justiça, integram o conselho os ministros da Saúde, da Fazenda, da Justiça e do Planejamento, Orçamento e Gestão. 
Como forma de solucionar os conflitos surgidos dessa estrutura institucional dupla, e refletindo a tendência observada em outros setores em razão da reforma de Estado brasileira, foi proposta a criação de uma agência reguladora para a saúde suplementar, vinculada ao Ministério da Saúde. Em dezembro de 1999, é criada a Agência Nacional de Saúde Suplementar (ANS), inicialmente também por meio de uma medida provisória, logo em seguida transformada em lei (em janeiro de 2000), inaugurando nova fase no processo de regulação.

A agência é vinculada ao Ministério da Saúde, o que explicita a concepção de regulação na esfera da saúde. Sua criação como agência reguladora, de certa maneira, esvaziou o papel do Consu, embaçando os limites das atribuições de cada um desses órgãos, respectivamente, na medida em que as funções normativas foram transferidas para a ANS. Formado por vários ministros de Estado, o conselho se reúne esporadicamente e fica limitado apenas à definição de macrodiretrizes e à supervisão das atividades de regulação, cabendo à ANS, de fato, a maioria das funções reguladoras.

Seguindo o modelo prescritivo de uma agência reguladora, a ANS, como autarquia sob regime especial, é dotada de autonomia administrativa, financeira, técnica, patrimonial e de gestão de recursos humanos, com mandato fixo de seus dirigentes. Sua relação com o Ministério da Saúde se dá por meio de um contrato de gestão, no qual são previstos os indicadores para a avaliação do desempenho da ANS, sendo esta a principal forma de controle de suas ações. Seus recursos são provenientes de arrecadação própria. As decisões são tomadas por uma diretoria colegiada e os dirigentes são indicados e nomeados pelo presidente da República, após aprovação pelo Senado, tendo seu mandato definido em lei. A agência tem poder legal para efetivar suas decisões. Após sua criação, ficaram bem mais claros os objetivos governamentais na regulamentação dos planos e seguros de saúde, constituídos após o debate iniciado na sociedade e no próprio mercado segurador. Nesse processo, a influência do ministro Serra foi decisiva. Ele demonstrou ser um propagador do instrumento regulatório de agências independentes, uma vez que na sua gestão o ministério já tinha criado a Agência Nacional de Vigilância Sanitária.

A criação da ANS significou a incorporação das tendências de reformas institucionais em curso, apesar das diferenças históricas e institucionais na traje- 
tória dos setores que foram objeto de regulação. Na experiência internacional mais recente, o modelo de agência reguladora, de forma mais típica, tem sido utilizado para a regulação de atividades antes de responsabilidade pública e que foram privatizadas ou tiveram o monopólio estatal flexibilizado, como forma de garantir o interesse público. Esse foi o caso no Brasil da criação da Aneel, da Anatel e da ANP. Nesse sentido, as agências expressam, ao mesmo tempo, a expansão da atividade privada para novas áreas e a reconfiguração das funções do Estado. Entretanto, no caso da assistência à saúde, essa não foi exatamente a trajetória histórica, uma vez que o mercado de saúde desenvolveu-se previamente à intervenção governamental. Diferentemente das outras agências que se voltaram para a formação e a diversificação de mercado, a ANS tinha a intenção de constituir mecanismos estatais de fiscalização e controle de preços, corrigir as 'falhas do mercado' e os problemas nas condições contratuais e preservar a competitividade do mercado, contribuindo para a sustentabilidade das empresas e gerando incentivos que beneficiassem os consumidores.

No setor da produção de serviços de saúde, as principais falhas de mercado identificadas pela economia da saúde são: a assimetria de informações entre clientes, operadoras e provedores de serviços - que produzem a seleção adversa ou o moral hazard -, a provisão inadequada de bens ou serviços e a seleção de riscos. Em razão dos mecanismos peculiares que caracterizam a formação da demanda na saúde, os quais tendem a elevações constantes de custo, ${ }^{224}$ as saídas dos agentes do mercado para maximizar ganhos é a privilegiação de clientes com baixo risco de utilização de serviços ou a imposição de altos prêmios pela expectativa de custos. Se essa seleção de riscos pode se dar por parte das empresas, que preferem oferecer cobertura para os riscos menores, por parte dos clientes pode ocorrer na situação pré-contratual a seleção adversa - ou seja, indivíduos tendem a adquirir seguros e planos de saúde quando já apresentam problemas de saúde - ou na situação póscontratual, quando tendem a consumir mais serviços em virtude de estarem

\footnotetext{
224 Costa e Ribeiro (2001) sumarizam bem o processo de formação de demanda no setor saúde, que é afetado por: transição demográfica, que gera demanda por serviços de alto custo e longa duração; transição epidemiológica, que eleva a morbidade associada a doenças crônicas e emergentes; inovação tecnológica e ampliação da capacidade terapêutica, que geram necessidades crescentes e demanda por atenção de alta tecnologia; autonomia decisória médica, com reflexo nas despesas de saúde; e ênfase em estratégias curativas.
} 
cobertos por planos, o que configura o risco moral, ou moral hazard. Este pode ocorrer também pelo lado dos prestadores de serviços, que tendem a solicitar ou realizar maior número de procedimentos quando existe a garantia do pagamento. Diante da possibilidade dessas falhas do mercado, a intervenção governamental é justificada pela necessidade de garantir a qualidade dos serviços e a amplitude de cobertura, uma vez que o mercado por si só não os garante de forma adequada.

A intenção de reorganizar o mercado foi a justificativa para a abertura ao capital estrangeiro, visando estimular a concorrência, e para a criação de numerosas exigências e regras econômico-financeiras para as empresas que operassem nesse mercado, entre elas a comprovação de solvência e a constituição de reservas técnicas.

Agregando esses dois grupos de objetivos - corrigir falhas do mercado e organizar o mercado, estimulando a concorrência -, a regulação por meio do mecanismo institucional de agência reguladora independente, entendida no âmbito da nova gestão pública como capaz de impedir a captura do Estado pelos interesses privados, foi vista como a possibilidade de obter maior convergência entre os diversos interesses afetados, de forma a obter ganho tanto para os diversos operadores do mercado quanto para os consumidores - ou seja, a política regulatória foi vista como geradora de um virtuoso jogo de soma positiva.

Com a criação da ANS, o conflito político se deslocou do Legislativo para a agência, na qual os diferentes atores buscam obter uma regulação que os beneficie. A participação da sociedade por intermédio dos vários segmentos sociais interessados é garantida na Câmara de Saúde Suplementar, embora de caráter apenas consultivo. Um instrumento de participação mais ativa são as câmaras técnicas, definidas para a discussão de assuntos específicos e formadas por membros indicados pelos segmentos que compõem a Câmara de Saúde. Outro instrumento de responsabilização usado pela ANS são as 'consultas públicas', por meio dos quais, com a utilização da internet, assuntos e propostas são apresentados para debate público. Esse modelo de consultas, principalmente por intermédio da Câmara de Saúde Suplementar e das câmaras técnicas, garante o espaço do debate para os componentes da complexa teia de atores do mercado da assistência privada - entre os principais, consumidores, operadoras e prestadores de serviços (hospitais e profissionais), 
incluindo também representação dos gestores do SUS - na tentativa de influenciar o processo regulatório. Mas, de acordo com o mecanismo institucional de agência reguladora, o caráter apenas consultivo dessas câmaras garante à ANS, por meio de uma diretoria colegiada, a autonomia decisória. Ao Conselho Nacional de Saúde, a quem legalmente compete atuar na formulação de estratégias e no controle da política nacional de saúde, fica garantido assento na Câmara de Saúde Suplementar na mesma condição dos demais componentes, ou seja, de forma apenas consultiva.

Essa autonomia tem sido questionada, na medida em que as decisões da ANS, muitas vezes, são consideradas pelos agentes do mercado como uma exorbitância dos preceitos legais. Na medida em que o arcabouço regulatório é constituído de um mix de lei, medidas provisórias, resoluções do Consu e decisões da ANS, os limites das competências da agência também não estão muito claros. No entanto, considerando a autonomia administrativa, financeira e política da ANS, por suposto ela é dotada de alto grau de discricionariedade, justificada pela necessidade de se distanciar dos interesses regulados e de atuar dentro da perspectiva técnica.

Na medida em que, por definição, cabe à ANS regular o mercado, suas estratégias precisam combinar a defesa dos consumidores com o desenvolvimento de um determinado perfil de empresas para atuar no setor e cujo resultado seja a obtenção de um equilíbrio vantajoso para a sociedade. Entre os vários conflitos que podem ser identificados nessa tarefa, Giovanella, Ribeiro e Costa (2002) chamam a atenção para o desafio de encontrar um ponto de equilíbrio entre direitos individuais abrangentes, nos quais se concentra o Código de Defesa do Consumidor, e as estratégias das empresas, ponto este capaz de assegurar a existência de um mercado competitivo e diversificado, formado por empresas sólidas e consumidores esclarecidos. ${ }^{225}$ Nesse con-

$\overline{225}$ O conflito entre as demandas de consumidores e a manutenção do mercado se expressa nas demandas e na insatisfação perante o órgão regulador, provocando manifestação do ministro José Serra em simpósio organizado pelo CNS e pelo Congresso Nacional em 2001, que funcionou como uma audiência pública, contando com a participação de todos os setores interessados: "A Agência Nacional de Saúde não é uma agência dos consumidores. Ela cuida do conjunto do setor. Ela tem que tornar o conjunto do setor viável, o que significa também defender os direitos dos consumidores. Mas ela tem que cuidar do conjunto. Isso também gera incompreensão quando não se unem em entidades de defesa do consumidor, que vêem nela uma concorrência, ou exijam que ela se comporte como se fosse um Procon de determinado Estado." 
fronto, as soluções apenas técnicas têm poucas chances de serem exitosas. Dificilmente, sem a pactuação nas esferas políticas será possível pensar na construção de um consenso pautado apenas pelas decisões técnicas no âmbito da ANS.

\section{Aspectos Substantivos e Alguns Resultados da Regulamentação}

Alguns aspectos gerais da legislação regulamentadora das atividades de assistência à saúde privada merecem ser destacados. Em primeiro lugar, consagrou-se a expressão 'assistência suplementar', entendida como “acréscimo à assistência integral e universal prestada pelo Sistema Único de Saúde" (Mesquita, 2002: 85). Com isso, fica demarcada a diferença em relação à assistência pública e exclui-se a perspectiva de ações complementares, consagrando-se o caráter dual da assistência à saúde.

Em segundo lugar, foram colocadas sob a abrangência da lei todas as pessoas jurídicas de direito privado, inclusive entidades de autogestão, que operem planos de assistência à saúde, considerando-se todas como operadoras de planos. ${ }^{226}$ Tanto seguradoras quanto hospitais que mantinham planos de saúde próprios foram obrigados a constituir pessoas jurídicas independentes para continuar operando no setor, criando a figura de sociedade seguradora especializada em planos de saúde. Essa foi uma solução para pacificar a disputa judicial quanto à competência para a regulação, a normatização e a fiscalização dos planos privados. Para os planos operados no sistema de autogestão, foram feitas pequenas concessões relativas à comprovação financeira da empresa, respeitando a sua especificidade ao não se constituir em uma operadora comercial, mas sim como uma atividade de uma empresa voltada para outros fins.

$\overline{226}$ Como Plano Privado de Assistência à Saúde, a legislação define: “a prestação continuada de serviços ou cobertura de custos assistenciais a preço pré ou pós-estabelecido, por prazo indeterminado, com a finalidade de garantir, sem limite financeiro, a assistência à saúde, pela faculdade de acesso e atendimento por profissionais ou serviços de saúde, livremente escolhidos, integrantes ou não de rede credenciada, contratada ou referenciada, visando à assistência médica, hospitalar e odontológica, a ser paga integral, ou parcialmente, às expensas da operadora contratada, mediante reembolso ou pagamento direto ao prestador, por conta e ordem do consumidor" (inciso I, artigo $1^{\circ}$ da última versão da lei $9.656 / 98$, alterada pela MP 2.177-44). 
Do ponto de vista econômico-financeiro, a legislação estabeleceu as condições de funcionamento e operação das empresas de planos de saúde, referentes, simultaneamente, à capacidade de prestar serviços assistenciais e à viabilidade econômico-financeira. Entre essas condições, as operadoras são obrigadas a registrar reservas e provisões técnicas. Além disso, passam a ser controladas, estando sujeitas a fiscalização, multas, direção fiscal, liquidação extrajudicial etc. A necessidade de demonstrar essas condições passou a exigir visibilidade e transparência das operadoras, que se vêem premidas a mudanças gerenciais e, sobretudo, a desenvolver sistemas de informação.

Da perspectiva assistencial, foram estabelecidas regras rígidas de proteção ao consumidor, como o controle de preços e a proibição de seleção de riscos e de rompimento unilateral dos contratos. A principal inovação foi a proibição da modulação da quantidade de produtos oferecidos por uma operadora de planos de saúde, com o estabelecimento do plano de referência obrigatório, pelo qual é vedada a comercialização de planos com coberturas menores. Isso significou a impossibilidade de exclusão de cobertura a qualquer doença e de limitação quantitativa de procedimentos em qualquer tipo de plano de saúde. Outra mudança importante foi a garantia de cobertura de doenças e lesões preexistentes à contratação dos planos de saúde, uma das formas mais comuns de seleção de riscos utilizada pelas operadoras. ${ }^{227}$

Quanto à relação com o sistema público, a legislação definiu a questão do ressarcimento de despesas no caso de utilização da rede pública por usuários de planos de saúde como forma de desestimular essa prática. Para sua operacionalização, tornou-se obrigatório para as operadoras de planos o fornecimento aos órgãos reguladores do cadastro de beneficiários, de modo a permitir a identificação do uso indevido dos serviços públicos para fins de cobrança. Afora essa questão, não há mais nenhuma menção ao sistema público ou a sua relação com o sistema privado. Ou seja, a regulação restringiu-se unicamente à assistência supletiva, não se discutindo o sistema de saúde como um todo. A possibilidade de um reordenamento da produção privada de

$\overline{227}$ Com a regulamentação, só se torna possível alegar a preexistência após dois anos de contrato, além de que o ônus da prova passa a caber à operadora. No caso de conhecimento pelo usuário da doença ou lesão não é permitida a exclusão de cobertura, mas mantém-se uma carência de dois anos. 
serviços de saúde segundo a lógica da gestão de bens públicos não foi incluída na regulação, não se disciplinando a relação público/privado de maneira mais abrangente. A questão da transferência de recursos públicos para o setor privado pela via das deduções fiscais também não foi objeto da regulação, embora tenha repercussões sobre o financiamento global da assistência à saúde.

Ao que parece, o processo regulatório teve, até o momento, maior avanço no plano político-institucional do que no da implementação das regras legais. Vários obstáculos ao cumprimento da legislação são identificados pelo órgão regulador. Entre eles figura a adaptação dos contratos antigos às novas regras. Por pressão das seguradoras e das entidades de defesa do consumidor, diante da ameaça de grande elevação dos preços dos prêmios, a ANS foi levada a suspender a obrigatoriedade de adaptação, de forma que, na prática, mantêm-se as exclusões e a seleção de riscos nos contratos antigos, que constituem ainda cerca de $85 \%$ dos planos contratados individualmente. Permanecem também as dificuldades para o ressarcimento ao SUS e para regular os mecanismos tradicionais de transferência de clientes entre os setores público e privado. Apesar de regulamentado e implantado, o ressarcimento apresenta baixa efetividade, em virtude dos recursos e ações judiciais impetrados pelas operadoras. ${ }^{228}$

As resistências à regulamentação foram muitas, como era de se esperar, tendo em vista o desenvolvimento do setor de forma desregulada. Uma expressão disso foi o desencadeamento de numerosas disputas judiciais, ressaltando-se entre elas o questionamento sobre a legalidade de regular a atividade seguradora, já vinculada a outro sistema regulatório (CNSP e Susep), e sobre a obrigatoriedade de adaptação dos contratos anteriores à legislação regulamentadora. A primeira questão foi solucionada ao se eliminar da legislação qualquer referência a seguradoras, obrigando-as a constituírem outras empresas para atuar como operadoras de planos de saúde; a segunda levou à eliminação da exigência, de forma que a adaptação dos contratos torna-se

228 Até junho de 2001, entre os atendimentos hospitalares do SUS a usuários de planos privados, o sistema de ressarcimento tinha identificado menos de $1 \%$ do total de AIHs, a Autorização de Internação Hospitalar. Isso significou a cobrança do valor de R \$21,6 milhões, dos quais apenas R\$ 3,4 milhões tinham sido recebidos. O SUS só permite a identificação do usuário no caso de atendimentos hospitalares, de forma que os atendimentos ambulatoriais, entre eles os relativos a procedimentos de alto custo que costumam ser evitados pelos planos privados, não podem ainda ser identificados para fins de ressarcimento, embora isso esteja sendo modificado. 
uma decisão do consumidor. Até o momento, a ANS não foi capaz de construir um consenso capaz de viabilizar a migração dos consumidores para novos contratos adaptados à legislação regulamentadora.

Os pontos mais polêmicos foram aqueles que significaram ampliação de cobertura e, portanto, do custo dos planos. A adaptação às novas regras econômico-financeiras e assistenciais, e também à fiscalização pela ANS, força os agentes do mercado a alterações gerenciais e organizacionais, sob pena de não obterem autorização para funcionamento. O controle de preços também impossibilitou o repasse do aumento de custos para o preço dos planos, passando a exigir maior eficiência das operadoras, além de prover incentivos para ações preventivas como forma de diminuir a sinistralidade. Essas alterações na gestão da assistência têm suscitado um choque de interesses entre operadoras e prestadores de serviço, sobre quem também incidem as medidas que visam diminuir os custos da assistência, uma vez que, na maioria das vezes, elas implicam restrições na liberdade para solicitar e realizar procedimentos médicos.

Uma das formas de resistência à regulação foi a tentativa de alguns segmentos de serem considerados exceções às regras, uma vez que a legislação os igualou a todos, considerando-os como operadoras de planos de saúde. Esse foi o caso das Unimeds, seguradoras e autogestão. Neste último caso, de acordo com a Asaspe-MG, a maioria das empresas associada está questionando juridicamente a regulamentação, e apenas uma minoria optou por se enquadrar na totalidade das exigências da legislação.

Sem entrar no mérito dos pressupostos normativos que justificam a criação de agências reguladoras, entretanto, a autonomia da ANS não parece garantir o distanciamento em relação aos interesses privados dos atores submetidos à regulação e menos ainda a obtenção de um resultado de soma positiva em que todos poderiam ganhar. As pressões sofridas pela ANS não são poucas, e o episódio de alteração da penúltima medida provisória ilustra bem não apenas a pressão, mas também as dificuldades de se obter algum nível de consenso entre os agentes do mercado. A intensa pressão de organismos de defesa do consumidor - aliados às associações de profissionais - à MP 2.177-43, a qual consideraram como favorável à seleção de riscos e à limitação do acesso, levou à sua retirada pelo governo. Os principais motivos de insatisfação foram, por um lado, a possibilidade de flexibilização na definição de preços e 
produtos, possibilitando a comercialização de planos com cobertura condicionada à disponibilidade regional de serviços, e, por outro, a autorização para planos organizados em sistema hierarquizado e gerenciado. Neste último caso, a reação de consumidores e médicos foi contra a utilização de mecanismos que têm sido adotados internacionalmente, particularmente nos Estados Unidos, com vistas a controlar a demanda por serviços de saúde e reduzir custos, vinculados ao que ficou conhecido como atenção médica gerenciada (managed care). ${ }^{229} \mathrm{Em}$ linhas gerais, a atenção gerenciada afeta a demanda de saúde, introduzindo controles para escolha e utilização de serviços pelo usuário e para os profissionais médicos, limitando sua autonomia diagnóstica e terapêutica - daí ser um elemento de agregação de interesses entre esses dois atores. Inclui controle do usuário por médicos generalistas; controle dos encaminhamentos a especialistas e clínicas especializadas (o gate keeping); controle de terapias seriadas e de longa duração, além de internações; e controle rígido de despesas e incentivo aos profissionais médicos para a redução de despesas por meio de remuneração diferenciada. ${ }^{230}$

Apesar de atender às operadoras de planos de saúde, premidas pelo aumento de custos associados à configuração da demanda na saúde e pressionados mais ainda pela ampliação das coberturas como conseqüência da regulação, o governo, por intermédio da ANS, teve que recuar. Refletindo a insatisfação dos médicos e sua histórica resistência a qualquer forma de regulação de suas atividades, em agosto de 2002 foi promulgada Resolução do Conselho Federal de Medicina que dispunha sobre questões relacionadas à relação com as operadoras de planos de saúde. A resolução CFM 1.642/2002 é uma tentativa de resguardar a auto-regulação das atividades médicas em todos os aspectos, inclusive remuneração, e reflete o conflito entre operadoras de planos de saúde e prestadores de serviço. Entre outras questões, reafirma que as empresas que atuem sob forma de prestação direta ou intermediação de serviços médicos devem respeitar a autonomia profissional dos médicos sem sujeitá-los a

229 Esse sistema é largamente discutido na literatura. Na brasileira, podemos citar, entre outros, Bahia (1999), Almeida (1995), Ugá et al. (2002), Costa e Ribeiro (2001).

${ }^{230}$ O principal argumento da categoria médica contra o gate keeping é que a proposta "barra o atendimento direto e o direito de escolha do profissional que atenderá o cliente" (Regina Parizi, presidente do CFM, em encontro para discutir a questão realizado em Brasília em 27/8/2001 e que reuniu representantes de CFM, AMB, CRMs e senadores. Disponível em: <www. amb.org.br>). 
qualquer restrição, garantindo-se a irrestrita disponibilidade dos meios de diagnóstico. ${ }^{231}$

Até o momento, pode-se dizer que a regulamentação da saúde suplementar tem causado insatisfação em todos os segmentos, em vez de uma acomodação dos conflitos. Mais do que um jogo de soma positiva, aparentemente, parece um jogo em que todos sentem que perdem. O episódio de repúdio à MP 2.177-43 pelos consumidores e profissionais de saúde ilustrou bem a dificuldade de conciliar os conflitos de interesse ou a possibilidade de 'desenvolver o mercado de forma justa', conforme defendido pelas instâncias governamentais. Se a proposta contida na MP poderia impedir a exclusão de muitas operadoras do mercado, pois possibilitava maior controle dos custos, para os consumidores e profissionais feria sua liberdade de acesso ou de atuação profissional, respectivamente, podendo ainda significar redução da cobertura tão duramente conquistada após a regulamentação do setor. ${ }^{232}$ Essa compatibilidade circunstancial de interesses entre consumidores e profissionais de saúde, os primeiros interessados na maior cobertura e os segundos, na realização de maior número de procedimentos que pudessem significar maiores ganhos para a categoria, os contrapõe aos interesses das operadoras e à regulamentação da ANS. ${ }^{233}$

A atuação das entidades de defesa dos consumidores mostra algumas ambigüidades. A forte reação à proposta de planos gerenciados ou diferenciados em razão das disponibilidades regionais, por um lado, e a rejeição à adaptação dos contratos antigos que são excludentes e não contemplam os ganhos assistenciais da regulamentação, por outro, mostram uma racionalidade de caráter imediatista e um comportamento free rider. Por não ter incentivos imediatos

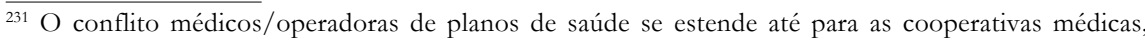
que têm atuado da mesma forma que as demais operadoras, inclusive com propostas de pagamento diferenciado como forma de estímulo à redução da realização de procedimentos diagnósticoterapêuticos.

232 Matéria publicada no Jornal do Brasil em 28/8/2001 sobre declaração do ministro da Saúde expressa a dificuldade de desenvolver o mercado vis-à-vis às demandas de consumidores: "Serra alertou, no entanto, para a situação econômica difícil dos planos de saúde. De acordo com os números no ministério metade das seguradoras não tem condição de continuar no mercado e o governo não vai injetar dinheiro no setor. As pressões que recebemos nesse sentido são enormes. Mas a situação não é tão simples porque o governo também não pode simplesmente deixar que elas quebrem e joguem os milhares de usuários de volta no Sistema Único de Saúde."

233 Essa aliança pode ser considerada circunstancial, na medida em que os consumidores querem também o menor custo. Uma vez que a maior cobertura provoca a elevação dos preços dos planos, o que pode favorecer os profissionais que reivindicam também melhor remuneração, o conflito de interesses tende a despontar. 
para aderir aos novos planos - que significam pagamento maior -, o consumidor, por meio de suas entidades representativas, concorda com menor cobertura e disputa na Justiça nos casos em que é penalizado pelas restrições dos contratos antigos. Essa atitude enfraquece o impacto da ação regulatória governamental no conjunto dos planos de saúde e ainda traz para o centro da arena regulatória o Judiciário, na medida em que o tratamento da questão é feito com base em uma concepção de direitos individuais do consumidor.

Os sistemas de autogestão e o conjunto de planos coletivos ligados a empresas empregadoras, de natureza diferente dos contratos individuais, têm tido problemas para adaptar-se, e as empresas vêm sendo desestimuladas a manter, ampliar ou criar novos sistemas. ${ }^{234}$ Nesse caso, é questionável se esse tipo de assistência privada deveria ser alcançado pela regulação. É claro que o processo regulatório foi desencadeado pelas queixas dos consumidores que se sentiam lesados nos seus contratos com operadoras comerciais. Esse tipo de queixa não era usual entre os participantes de planos coletivos empresariais ou ligados a organizações públicas, nos quais a inclusão no plano está associada ao vínculo de trabalho, e não à contratação de um produto no mercado, não se configurando como uma relação de consumo. A lógica da regulação foi no sentido de regular um mercado de compra e venda de serviços de saúde, situação em que parece questionável a inclusão dos planos coletivos, particularmente na modalidade de autogestão, pelo menos na maioria dos aspectos. No caso dos planos coletivos contratados com as operadoras comerciais, a situação é mais matizada, uma vez que os mecanismos de seleção de riscos operavam também nesses casos. A intenção dupla da regulação, ao considerar aspectos econômico-financeiros, apresenta um problema lógico. Ao mesmo tempo que teve como principal parâmetro o modelo assistencial da autogestão, no aspecto econômico-financeiro preocupou-se em organizar o mercado, criando exigências e regras para as empresas que operassem nesse mercado com base no modelo do mercado segurador. E fez isso igualando como operadoras todas as pessoas jurídicas

\footnotetext{
${ }^{234}$ Uma das dificuldades tem sido a obrigatoriedade de fazer o provisionamento dos encargos decorrentes do plano de saúde no balanço da empresa, além de constituir reservas.
} 
que operassem planos de saúde, mesmo quando isso não caracterizasse uma relação comercial e, portanto, de consumo. ${ }^{235}$

Apesar das resistências e controvérsias, os diferentes segmentos estão progressivamente se adaptando à regulação, embora admitam uma certa estagnação no setor e diminuição acentuada da rentabilidade. A ação da ANS tem sido concreta e se expressa via cancelamento do registro de operadoras, liquidação de outras ou instalação de diretorias fiscais. Canais de comunicação com os usuários foram estabelecidos, são utilizados e têm funcionado tanto para diminuir a assimetria de informações entre consumidor e operadora quanto como um instrumento para a tomada de decisão pela ANS. Os planos coletivos continuam sendo a sustentação das operadoras. Neles, as adequações relativas à ampliação de cobertura foram muito menores. Além disso, têm possibilidade de ganho de escala e apresentam sinistralidade muito menor. Por sua vez, os clientes individuais apresentam taxa muito maior de utilização de serviços, grande rotatividade nos planos, além de inadimplência. Contra os planos coletivos empresariais, entretanto, atuam as tendências de redução de pessoal e de salários indiretos, que caracterizam a conjuntura empresarial atualmente. Em conseqüência, o mercado não tem apresentado a expansão esperada a partir da regulamentação. Uma adaptação do mercado à conjuntura tende a ser o aumento de fusões e incorporações de empresas, para obter ganhos de escala, alterando o perfil do mercado em virtude da regulamentação. Apesar da sua insatisfação, as operadoras reconhecem que no momento não existem perspectivas de mudanças no sentido da regulamentação.

235 Sobre isso, assim se pronunciou o presidente da Asaspe-MG, Virgílio Carneiro Baião, em entrevista realizada em julho de 2002: "A lei foi feita para planos comerciais. Todo texto da lei fala em 'quem compra, quem comercializa'. Fala de uma relação de consumo. Planos de autogestão não têm relação de consumo, mas relação de trabalho. É um salário indireto registrado no Ministério do Trabalho como plano de remuneração, às vezes entrando até no acordo sindical. Segmentos completamente diferentes foram tratados da mesma forma. Isso só favorece as seguradoras que não tiveram que fazer adaptações e puderam ser mais competitivas com a equalização dos outros segmentos. A legislação escolheu um modelo segurador e nivelou o resto como se seguradora fosse. Virou um negócio terrível, que prejudica tremendamente a autogestão, mas também a Unimed e a medicina de grupo." 


\section{Síntese}

O que é possível concluir da análise do processo de regulação da assistência à saúde privada, na perspectiva de compreender o formato atual da assistência com base em um argumento que fundamenta a explicação nos componentes institucionais formados na sua própria trajetória? Embora algumas análises tenham interpretado a regulação do setor como expressão de um processo de 'privatização da saúde', semelhante ao que corria em outros setores, particularmente naqueles da provisão de serviços públicos, uma análise mais acurada do processo contraria essa interpretação. Em vez de uma privatização de atividades que, por suposto, para serem privatizadas deveriam ser estatais, $\mathrm{O}$ que se expressa na direção tomada pela política de saúde é a consolidação e a oficialização do caráter dual ou híbrido dessa política no Brasil. Tal caráter se expressa na dupla institucionalidade, no duplo locus decisório e normativo e, fundamentalmente, na segmentação dos usuários. A própria terminologia adotada para designar a assistência privada, que passa a ser definida formalmente como assistência suplementar, consagra essa dualidade.

A armadilha de explicar a regulação do mercado de saúde por uma pretensa intenção de privatização da saúde é tentadora, na medida em que ela reflete um contexto internacional e nacional de ênfase em reformas do Estado e do aparato governamental no qual são redefinidas tanto a concepção de bens públicos quanto a forma de provisão desses bens. Nesse contexto, a valorização de alternativas de mercado para a provisão de bens públicos torna-se uma característica de muitas reformas, inclusive no âmbito das ações e dos serviços de saúde. É nessa perspectiva que ganha importância o desenvolvimento de mecanismos para a regulação de atividades antes desenvolvidas pelo Estado e/ou consideradas de interesse público, expressando a passagem do Estado intervencionista ou Estado positivo para o Estado regulador. Nesse contexto, são desenvolvidos novos arranjos institucionais que visam propiciar o desempenho do novo papel do Estado.

A regulação da assistência à saúde privada se insere nesse contexto e reflete algumas concepções normativas associadas ao movimento de reforma do Estado que caracterizaram a década de 90 no país. Particularmente, o formato institucional assumido pela regulação em virtude da constituição de uma agên- 
cia reguladora independente é uma expressão nacional de paradigmas desenvolvidos no processo de privatizações de atividades estatais, embora não se limitando a essas e incorporando também outras atividades consideradas de interesse público.

Entretanto, a regulação do mercado de planos privados de saúde não significou a retirada do Estado da provisão de serviços de saúde, tampouco mudança normativa da política nacional de saúde, realizada via SUS. Ao contrário, o processo regulatório se fez de forma independente da política nacional de saúde e sem mesmo negá-la ou redirecioná-la oficialmente. Sem interferir formalmente na política voltada para a assistência pública, a regulação desnudou e formalizou o modelo segmentado e dual que se constituíra historicamente na assistência à saúde, em razão de escolhas políticas anteriores e, mesmo, de nãodecisões. Ao assumir implicitamente a segmentação e ao ter como um de seus objetivos a ampliação do mercado de planos de saúde, a política regulatória tornou evidente, entretanto, o caráter meramente formal - do ponto de vista dos fundamentos normativos que norteiam as decisões governamentais - dos princípios do SUS, particularmente a universalidade e a igualdade de acesso. $\mathrm{O}$ processo político que engendrou os objetivos da regulação e o modelo regulatório confirma o sentido da política de assistência pública à saúde, voltada prioritariamente para os segmentos sociais que não têm capacidade de adquirir planos de saúde no mercado ou que estão excluídos dos planos coletivos, em virtude da maior precariedade de sua inserção no mercado de trabalho. O enfraquecimento da proposta de um sistema público de cobertura universal que já se fazia na prática com base em mecanismos institucionais consolidados fica formalizado na nova política regulatória que passa a integrar o conjunto das políticas de saúde. Em suma, a regulação da assistência privada não significou um movimento deliberado de privatização, porém a oficialização do sistema segmentado da assistência à saúde no Brasil.

Mas isso se faz como em um mundo de sombras, omissões e ocultamento, na medida em que a relação entre o sistema público e o privado não é enfrentada, exceto na questão do ressarcimento ao SUS das despesas efetuadas com serviços prestados a usuários de planos privados pelo sistema público. Embora a questão do ressarcimento tenha sido tratada como um mecanismo de aprimoramento da gestão pública e de relação entre o sistema público e priva- 
do, ela reafirma o reconhecimento oficial da segmentação de clientelas. $\mathrm{Na}$ definição da política regulatória, não foi considerada a definição mais ampla da política de saúde com relação à formatação adequada do mix privado/ público na assistência à saúde ou do papel do sistema privado no sistema de saúde brasileiro. Ou, ainda, a regulação não significou um reordenamento da produção privada segundo a lógica de bens públicos; apenas se regulou um mercado considerado de interesse público, buscando garantir direitos do consumidor, e não o acesso a serviços que fossem assumidos como de responsabilidade pública. E muito menos foi tratada a questão da vinculação com a rede privada prestadora de serviços de saúde, que, em grande parte, é onde há uma interface entre os sistemas público e privado. Outra questão que não foi objeto da regulamentação foi o financiamento governamental indireto das atividades privadas com base nos mecanismos de renúncia fiscal. A omissão no tratamento da questão garantiu a sua permanência como uma forma de incentivo à assistência privada. Isso se deu ao mesmo tempo que se discutia e aprovava também no Congresso Nacional a ampliação de recursos para o SUS pela EC 29. O que é outra maneira por meio da qual se expressaram a fragmentação e a ausência de uma política de saúde global capaz de unificar a regulação e a normatização dos dois sistemas de saúde. A política regulatória estabelecida foi restrita ao segmento privado de operação de planos de saúde.

Seguindo essa política, o Ministério da Saúde, como o espaço institucional de formulação e execução da política de saúde, de forma direta ou indireta por intermédio da ANS, passa a ser a instância reguladora de dois sistemas de assistência à saúde não apenas díspares do ponto de vista conceitual e jurídico, mas completamente independentes - pelo menos formalmente - e com coberturas, clientelas e qualidade bastante diferenciadas. Um deles, o SUS, fundamentado na concepção do direito à saúde - portanto, de caráter universal e igualitário; e o segundo, baseado na lógica do mercado em que a participação é desigual, embora formalmente livre, sendo os planos de saúde vistos como produtos a serem registrados e controlados quanto à qualidade e ao preço, mas também como quantidade variável de produtos a serem consumidos. $\mathrm{Na}$ contramão dos princípios constitucionais, não só com respeito a aspectos substantivos da assistência à saúde (como a integralidade e a igualdade), mas inclusive quanto à definição dos fóruns democráticos de decisões no âmbito do 
setor saúde, a regulamentação dos planos e seguros de saúde referendou a dualidade institucional, ideológica e programática do sistema de saúde brasileiro. Nesse sentido, a política regulatória tem como conseqüência a fragilização do projeto SUS do ponto de vista político-ideológico, além de reforçar as crenças cognitivas a respeito dos dois sistemas. ${ }^{236}$ No âmbito do Ministério da Saúde, foram reunidas, como objeto das políticas governamentais, as duas modalidades institucionais por meio das quais se desenvolveu a assistência à saúde, embora reguladas de forma separada e com base em instrumentos diversos.

Isso significa que o Estado, ao mesmo tempo que assume novas funções de Estado regulador, não abandonou suas funções intervencionistas e continua sendo responsável por um sistema nacional de saúde que oferece cobertura ampla para cerca de $75 \%$ da população. A regulação estatal da assistência à saúde convive com a responsabilidade estatal pela assistência, embora para clientelas diferentes. As duas faces estatais coexistem em um único ministério, apesar das contradições entre ambas, que se expressam em mecanismos institucionais de decisão completamente díspares. Estes, por sua vez, refletem pressupostos políticos também diversos, não só relativos ao papel do Estado como ao da gestão pública. Na gestão do SUS, a participação de representantes da sociedade e dos gestores das diversas instâncias subnacionais de governo é garantida por meio de diversos arranjos institucionais, que permitem não só maior responsabilização do Poder Público, como também a participação no processo decisório. No caso da assistência suplementar, o arranjo institucional de uma agência reguladora dotada de alto grau de autonomia administrativa, decisória e punitiva não considera as instâncias decisórias e gestoras do SUS. A essas não é submetida a ANS, que, em virtude de uma concepção técnica e profissional de responsabilidade, é submetida a mecanismos de responsabilização que seguem, principalmente, a lógica da avaliação de resultados.

236 Em entrevista, um diretor da ANS declarou existir no âmbito da ANS uma discussão no sentido de se articular o sistema privado à política nacional de saúde, particularmente ao se utilizar a regulação como instrumento de política pública para aumentar a responsabilidade da assistência privada perante a saúde da população atendida, de modo a ter como resultado a melhoria do perfil de saúde da população, por meio, por exemplo, de ações preventivas. Mas como chamam atenção corretamente Bahia e Viana (2002: 16): “a ANS difunde conceitos, e acolhe iniciativas que entram em conflito com as diretrizes de universalização, equidade e descentralização do sistema público de saúde." 
Entretanto, a própria regulação da assistência suplementar não demonstra redução do intervencionismo estatal, mas, ao contrário, submete ao controle governamental atividades até então atuando no mercado com mecanismos de auto-regulação. Na medida em que não é posterior à privatização deliberada de atividades antes reguladas pela propriedade pública, a política regulatória, de fato, significou a introdução do controle estatal sobre atividades privadas antes desreguladas. Nesse sentido, a política regulatória para a assistência privada estaria levando ao que Boschi e Lima (2002) sugeriram como sendo o retorno do Estado interventor pela via do Estado regulador, embora com base em pressupostos normativos que justificam a intervenção para corrigir as falhas do mercado e alcançar maior eficiência.

O resultado é a configuração de um padrão regulatório, no caso da saúde, que combina várias formas de ação reguladora: 1) a propriedade pública, pela manutenção e, até, expansão de uma ampla rede de prestação de serviços diretamente pelo Estado; 2) a atividade regulatória, por órgãos da burocracia do Executivo, no caso da regulação das atividades privadas vinculadas diretamente ao SUS; e 3) e a regulação, no caso da assistência supletiva. A difusão do modelo regulador das agências independentes, como ampliação da intervenção governamental, não substituiu, assim, os legados institucionais previamente constituídos.

A regulação tanto significou a constituição de regras, expressas na legislação que regulamentou a assistência médica supletiva, como compreendeu a criação de um mecanismo institucional para monitorar e promover a submissão às regras, que foi a ANS. Essa regulação expressou a concepção corrente a respeito da regulação governamental de atividades econômicas, ou seja: estabelecer regras que viessem assegurar o desempenho por agentes privados de atividades consideradas relevantes de uma forma que atendesse a critérios de sustentabilidade econômica e social. De uma perspectiva econômico-normativa, a regulação teve como justificativa a correção de falhas do mercado, particularmente a assimetria de informações entre os agentes do mercado, a seleção de riscos, a seleção adversa e a provisão inadequada de serviços de saúde. Ao mesmo tempo que visou estimular o mercado por meio de sua organização e do estabelecimento de condições para a competitividade, inclusive buscando a credibilidade necessária para atrair investimentos estrangeiros mediante o esta- 
belecimento de regras claras, buscou proteger o consumidor dos efeitos da ética utilitarista pela qual se orienta o mercado, que, no caso da assistência, tem conseqüências para a própria saúde. Os objetivos visados foram: estimular a competição; fiscalizar a atividade, com o estabelecimento de regras e a aplicação de sanções; controlar preços; e fixar parâmetros para a assistência. Para isso tratou-se, de um lado, de regular e sanear o mercado, dando tratamento igual aos diversos segmentos que operavam no mercado, desde as seguradoras até os sistemas de autogestão; e, de outro, de definir o conteúdo dos contratos no sentido de garantir a cobertura mínima aceitável, estruturando a oferta dos serviços, de modo a atender a uma agenda de objetivos que fora estabelecida no processo político de constituição da política regulatória.

Nesse processo, antigos e novos atores configuraram uma arena bastante conflitiva que, grosso modo, agregou, de um lado, as operadoras de planos de saúde e, de outro, os consumidores e os prestadores de serviços, sejam profissionais médicos, sejam organizações hospitalares - o primeiro grupo, movido pelo interesse de custos mais baixos; os segundos, interessados na maior cobertura possível. O debate parlamentar e as pressões no sentido de influenciar o processo decisório expressaram as conseqüências das políticas anteriores sobre o processo político, ao configurarem a arena política na qual se confrontaram os diferentes interesses construídos na trajetória da assistência privada. Os efeitos de feedback se expressaram também nas ambigüidades na percepção dos usuários e decisores sobre a política de saúde. A imbricação entre a noção de saúde como direito universal à atenção integral e a aquisição de um produto no mercado no qual se busca garantir esse direito, e a defesa do sistema de autogestão, quase sendo considerado como não fazendo parte do sistema privado por integrar contratos de trabalho, são alguns exemplos das conseqüências cognitivas da dualidade do modelo de assistência do país.

Se no processo de formação da agenda e definição da política o Congresso Nacional foi o locus do debate político e das decisões, este passa a ser a agência reguladora, em torno da qual se constitui uma arena que tem como objetivo estabelecer ou mudar as regras. Na trajetória da regulação, a ANS não tem logrado obter um consenso entre os interesses em jogo, de forma que sob a pressão dos atores afetados pela ação reguladora tem ocorrido a redefinição de objetivos. O principal exemplo disso é a resistência dos consu- 
midores em migrarem para novos contratos que observem as novas regras, optando por permanecer vinculados a planos de saúde que se confrontam com suas próprias demandas. Agindo de acordo com seus interesses mais imediatos, obtiveram na Justiça o direito de permanecer nos antigos contratos, identificando no Judiciário a possibilidade de obter ganhos quando são objetivamente prejudicados por sua própria decisão.

Esse é um dos exemplos de como a política regulatória trouxe para o centro do processo a instância judiciária, que assume o papel de árbitro das ações reguladoras e dos conflitos entre consumidores e operadoras. Como a regulação parte da concepção mais ampla de direitos de consumidores, muitos conflitos superam a ação da ANS e passam a ser resolvidos no âmbito do Judiciário. Essa concepção é também um dos problemas da política regulatória, cuja formulação se deu a partir do segmento de planos e seguros contratados no mercado, embora os planos sejam em sua maioria coletivos, isto é, vinculados ao contrato de trabalho, e portanto não configuram uma relação de consumo. O tratamento homogêneo aos diversos segmentos que não são similares pode levar a efeitos não pretendidos, como a própria estagnação do crescimento dos planos empresariais, que constituem o pilar da assistência supletiva que se visou expandir, demonstrando a inadequação do modelo regulatório.

Mais do que um jogo de soma positiva, os conflitos em torno da ação reguladora parecem expressar uma situação em que todos os atores sentem que perdem ou que recebem poucos incentivos para sua atuação no mercado. $\mathrm{Na}$ medida em que todos buscam maximizar seus interesses particulares, não se obteve até agora um arranjo que de fato acomode os diversos interesses. Ao contrário dos pressupostos normativos que sustentam a superioridade de decisões tecnicamente informadas capazes de garantir a eficiência do mercado, a desconsideração dos elementos políticos do processo de tomada de decisão não tem levado a um jogo de soma positiva.

Concluindo, a regulação da assistência suplementar expressa a consolidação de dois movimentos que correm paralelos na década de 90: a implantação do SUS e a formalização do sistema privado, mantendo-se a segmentação e a separação entre os dois. A regulamentação dos planos privados não apenas formaliza a segmentação da assistência, mas sinaliza para um aprofundamento 
da cisão entre os dois sistemas: o público e o privado. É verdade que a criação da ANS reflete mudanças nas estratégias governamentais de cunho mais geral que concorrem para limitar o papel do Estado intervencionista, como a privatização, a liberalização e a desregulação, com a introdução de formas de rerregulação. Entretanto, na transposição desse mecanismo de regulação para o âmbito da saúde tem significado diferente, na medida em que a atuação privada precede a regulamentação governamental, embora possa ser reforçada por ela por várias razões. Em primeiro lugar, ao reconhecer, incentivar e normatizar as atividades privadas que se desenvolviam desde os anos 60; em segundo, por constituir uma arena política que passa a agregar e segregar um conjunto de atores, muitos dos quais se vêem, assim, completamente deslocados da arena da política de saúde mais abrangente - nesse sentido, enfraquecendo o debate político sobre o sistema público. Este último, por envolver políticas de caráter redistributivo, demandaria coalizões mais amplas e duradouras para sua sustentação política, o que parece ficar cada vez menos provável, na medida em que parte da ação política se desloca para o conflito pelo poder de normatizar a assistência privada.

Apesar disso, por razões estruturais, expressas principalmente na desigualdade social, e institucionais, na medida em que é efetiva a inserção do SUS na sociedade, o processo de institucionalização do sistema público segue seu caminho. Nada indica que em curto e médio prazos ele deixe de ser a referência principal para a assistência à saúde no país. Seu percurso, entretanto, reflete sempre as marcas da dupla institucionalidade da assistência à saúde no Brasil. 



\section{Conclusões}

O ponto de partida empírico deste estudo foi a constatação de que a assistência à saúde no Brasil, numa perspectiva institucional, é constituída por dois segmentos. O primeiro deles é o público-estatal, no qual o acesso é universal, gratuito e igualitário, com base em uma concepção de direito à saúde consagrado constitucionalmente. O outro é o segmento privado, no qual o acesso se dá em razão do poder de compra ou da inserção privilegiada no mercado de trabalho, caso em que o acesso à assistência é intermediado e financiado, total ou parcialmente, pelo empregador. Ao contrário da assistência pública, a assistência de caráter privado caracteriza-se pela diferenciação das características do produto, que se adquire em um mercado altamente competitivo e diversificado, embora concentrado geograficamente, tanto pelo lado da oferta quanto pelo da demanda.

A análise da trajetória da política de saúde levou à classificação do formato da assistência à saúde brasileiro como um sistema dual. Da perspectiva analítica, afirmar a dualidade implica considerar que não se trata da existência de um mix privado/público configurado em virtude de regras claras e precisas que definam os espaços respectivos de atuação do mercado e do Estado e as formas de relacionamento entre os dois campos de ação. Em vez disso, a assistência à saúde no Brasil se configura como uma dupla institucionalidade, e do ponto de vista jurídico-formal não existem vínculos entre as duas modalidades assistenciais, embora atualmente estejam submetidas à regulação procedente da mesma instância governamental, que é o Ministério da Saúde, direta ou indiretamente por intermédio de uma agência reguladora. 
Entretanto, essa regulação se faz com base em instrumentos regulatórios e mecanismos decisórios distintos da perspectiva dos fundamentos políticonormativos que os informam, reafirmando a independência e a diferenciação formal entre a assistência pública e a privada. Isso significa que a política de assistência à saúde atual revela não apenas duas formas distintas de acesso, financiamento e produção de serviços de saúde, mas também de atuação governamental. Nesse campo, o Estado atua tanto sob a forma de intervenção direta, responsabilizando-se pelo financiamento total e por grande parte da execução dos serviços de saúde, como pela regulação do mercado privado. Se no primeiro caso a intervenção governamental visa garantir o direito constitucional à saúde, que se traduz principalmente no acesso aos serviços de saúde, no segundo o objetivo é desenvolver o mercado, buscando garantir a concorrência e os direitos do consumidor que adquire planos privados de saúde.

Ao se orientar por duas lógicas distintas, e em grande medida até contraditórias, a própria ação governamental reforça a dualidade institucional do sistema de assistência à saúde, sugerindo a inexistência de um objetivo governamental de tornar realidade os dispositivos constitucionais. A ausência de suporte político por parte de grupos sociais relevantes e pelos principais afetados positivamente por uma política de saúde inclusiva demonstra também a inexistência de um consenso societário pela publicização efetiva da assistência à saúde, entendendo-se por isso a incorporação de todos os cidadãos ao Sistema Único de Saúde (SUS), legalmente garantida nos princípios constitucionais, mas de fato negada na realidade da assistência tal como ela tem se efetivado no país.

Produzir uma interpretação para essa configuração institucional da assistência e para o processo político subjacente à definição da política de saúde no Brasil foi o objetivo principal deste trabalho. Isso implicou a identificação dos mecanismos causais que produziram essa configuração, o que permite compreender por que a reforma da política no final dos anos 80 , que estabeleceu o sistema universal e público, não logrou incorporar todos os cidadãos à assistência pública. Na medida em que o formato institucional é o resultado das políticas de saúde, entendidas como um conjunto de decisões e ações governamentais, e também de não-decisões, o que se fez foi construir uma interpretação para a política de saúde atual. 
De acordo com o modelo analítico utilizado, essa interpretação considerou como fator explicativo principal as políticas de saúde prévias com base no conceito de dependência de trajetória, segundo o qual as decisões são limitadas pelas escolhas do passado, de forma que as políticas de saúde definidas particularmente a partir dos anos 60 afetaram a seqüência de escolhas posteriores e, por seus diferentes efeitos institucionais e políticos, condicionaram a política vigente. Nessa perspectiva teórica, que leva em conta os processos históricos, a análise desenvolvida da trajetória da política de assistência à saúde tratou de identificar os efeitos de feedback das políticas anteriores, considerando a dinâmica entre os processos decisórios e os arranjos institucionais constituídos em razão das escolhas definidas em momentos cruciais de redefinição de políticas, que se tornaram parâmetros segundo os quais as escolhas posteriores foram definidas. Em outros termos, tratei de identificar os mecanismos por meio dos quais as políticas de saúde definidas anteriormente afetaram o seu desenvolvimento posterior, particularmente ao influenciar o processo político não apenas por constituir atores e interesses, mas também por condicionar a formação de suas preferências e modelar as interações e o comportamento político dos grupos beneficiados por ela.

Para atender a esses objetivos, a trajetória da assistência à saúde no Brasil foi recortada em razão de três momentos cruciais. O primeiro foi o de constituição do modelo segmentado com base na configuração de um certo padrão público/privado nos anos 60; o segundo, o de formação e definição da reforma da política de saúde nos anos 80; o terceiro, o de implantação da reforma na década de 90 , paralelamente aos processos de formação e decisão da política regulatória da assistência privada, então denominada suplementar, em clara afirmação de sua autonomia em relação à assistência pública.

Sumarizando as principais conclusões apresentadas nos capítulos precedentes, considero que as políticas anteriores levaram à configuração e continuidade do sistema dual de assistência à saúde em razão de vários efeitos, todos interligados. Em primeiro lugar, as decisões governamentais voltadas para a assistência à saúde de caráter público ou para a ampliação de cobertura favoreceram a constituição de determinados padrões de assistência, fornecendo incentivos diretos e indiretos para o desenvolvimento do mercado privado de saúde, tanto no aspecto da prestação de serviços quanto no da gestão privada 
da assistência, paralelamente à ampliação da cobertura pública. Esses incentivos favoreceram o desenvolvimento da assistência médica de caráter empresarial em detrimento da assistência pública, encorajando a expansão de redes de produção e gestão da assistência à saúde. No caso da produção de serviços, a opção governamental pela compra de serviços privados favoreceu a expansão desse mercado, que teve na política previdenciária a garantia da demanda financiada pelo Estado. Por meio da alocação direta de recursos ou de incentivos fiscais, as políticas previdenciárias favoreceram o desenvolvimento de diversos segmentos empresariais e propiciaram o surgimento de instituições como a medicina de grupo, as cooperativas médicas e os sistemas de autogestão vinculados a empresas que administram planos de saúde para seus empregados. Nos anos 80 , também favorecida por incentivos fiscais às pessoas físicas, a assistência privada se expandiu para fora das empresas empregadoras por meio dos planos de saúde contratados diretamente pelo usuário com as diferentes operadoras comerciais de planos de saúde. O desenvolvimento dessas modalidades de assistência significou a institucionalização de formas diversificadas de financiamento, provisão e acesso à assistência, configurando o padrão segmentado da assistência no Brasil. Os investimentos privados no setor e a atuação dos diversos agentes do mercado - prestadores de serviços, operadoras de planos de saúde, empresas empregadoras e usuários da assistência privada -, favorecidos por decisões governamentais que encorajaram determinadas ações, levaram ao estabelecimento de padrões de comportamento difíceis de serem mudados.

Em segundo lugar, e em decorrência do efeito anterior, as políticas de saúde, ao modelarem diferentes identidades e clivagens sociais, contribuíram para a estruturação dos interesses privados na saúde e, nessa medida, condicionaram o conflito político e estruturaram o processo de tomada de decisões ao configurarem a arena da saúde e as disputas por alternativas de políticas. Os segmentos empresariais da saúde constituíram organizações de interesses e conseguiram concentrar recursos políticos que lhes permitiram obter significativa influência nos processos decisórios subseqüentes, particularmente na definição de reforma sanitária nos anos 80 e da política regulatória da assistência supletiva na década seguinte, ocasiões em que esses atores iriam defender os arranjos preestabelecidos. 
Os efeitos de feedback sobre o processo político não se limitam ao papel dos representantes dos interesses empresariais, mas se expressam também no comportamento dos beneficiados pela trajetória específica da política de saúde na condição de usuários. Na sua origem, por se vincular prioritariamente à Previdência Social, a assistência à saúde de caráter público reproduziu as diferenciações registradas entre as diferentes instituições previdenciárias, sendo uma expressão da cidadania regulada que caracterizou a constituição dos direitos sociais no Brasil. A unificação dessas instituições na década de 60 , com a conseqüente equalização dos benefícios e serviços, foi acompanhada da recriação de novas formas de segmentação, desta vez em razão da inserção de categorias privilegiadas de trabalhadores em formas privadas de assistência com base nas decisões governamentais voltadas para a ampliação da cobertura sob a forma de convênios da Previdência Social com empresas. Essas duas formas de segmentação de clientelas, com a correspondente armação institucional para garantir a cobertura de segmentos de trabalhadores, não favoreceram a constituição de uma identidade coletiva e de valores solidaristas entre o públicoalvo da política, capaz de articular uma demanda universalista. Ao contrário, propiciou a particularização das demandas de saúde e a constituição de identidades corporativas.

De forma indireta, esse modelo teria conseqüências para a implantação da reforma da política nos anos 90, de sentido universalista e publicista, que não iria contar com o apoio efetivo, embora o tivesse formalmente, dos setores mais mobilizados dos trabalhadores. Por estarem incluídos previamente em formas privadas de atenção à saúde vinculadas ao contrato de trabalho, esses segmentos, na prática, deram sustentação à assistência privada e constituíram um veto implícito à universalização da assistência pública. A falta de identificação dos trabalhadores organizados com uma assistência pública e igualitária e a falta de incentivos para apoiar uma reforma que, pelo menos a curto prazo, tenderia a lhes trazer perdas objetivas, mesmo que de forma passiva, contribuíram para o enfraquecimento da proposta da reforma sanitária, de caráter publicista e universalista, e para o fortalecimento da segmentação de clientelas, reforçando a perspectiva de que ao SUS cabe a cobertura da população mais pobre e em condições desfavoráveis de inserção no mercado de trabalho. Ao se constituir inicialmente de forma segmentada, o formato 
institucional da assistência não favoreceu a consolidação de uma proposta de cidadania inclusiva e igualitária, da forma idealizada nos princípios da reforma consagrada constitucionalmente, a qual não foi o resultado de uma demanda coletiva dos usuários.

As políticas prévias tiveram também efeitos sobre a capacidade governamental de implementar a reforma definida nos anos 80 por motivos associados à própria natureza da assistência à saúde, que demanda a disponibilidade de uma rede diversificada de serviços de saúde. Para permitir, efetivamente, o acesso universal, seria imprescindível ao SUS dispor de uma rede de atendimento ampla, própria ou regulada estatalmente de forma a garantir a prestação dos serviços pela rede privada. O veto à expansão da rede pública de prestação de serviços ao longo da trajetória da política de saúde, associado à opção pela compra de serviços privados, levou a uma dependência da rede privada para a garantia da assistência pública. Como essa opção não foi acompanhada do desenvolvimento da capacidade reguladora do governo, fortemente penetrado pelos interesses dos prestadores privados por meio dos anéis burocráticos, a conseqüência foi a submissão da lógica da atuação pública à lógica dos interesses privados. Esse legado político e estrutural das políticas coloca hoje limites para a ampliação do atendimento e para a eliminação das barreiras ao acesso em uma situação em que a conjuntura econômica e ideológica não inclui na agenda a ampliação da rede pública. Independentemente disso, a prática de compra de serviços tende a ser readotada, sendo considerada a resposta natural, de forma que a ampliação da rede pública sequer tem entrado no debate público. Embora a natureza privada dos estabelecimentos de saúde não impeça por si só a publicização da rede ou serviços contratados, a configuração institucional híbrida do sistema de saúde brasileiro causa constrangimentos, de fato, para que se consiga fazer prevalecer o interesse público sobre o privado.

Em conseqüência dos efeitos do legado das políticas prévias, a reforma sanitária definida na Constituição de 1988 foi um processo de inovação limitada, caracterizado tanto por uma ruptura em termos jurídico-formais do padrão de cidadania regulada e segmentada como por elementos de continuidade, que se traduzem na convivência entre formas públicas e privadas de assistência, apesar da universalização formal da atenção pública. Essa 
duplicidade se expressa no próprio texto constitucional, se concretiza pelo aprofundamento das características do modelo híbrido da assistência e se consolida com a regulação da assistência privada no final dos anos 90 .

A reforma da política de saúde foi, assim, o resultado de uma confluência de fatores endógenos e exógenos à própria política. De um lado, a inovação foi possibilitada pela conjuntura política mais ampla de democratização e pela configuração interna de uma crise setorial; de outro, o legado das políticas prévias levou à convivência da inovação com a continuidade. O contexto político permitiu que novos atores, portadores de uma proposta inovadora, fossem incorporados à arena setorial e conseguissem alterar a agenda e articular apoio para a aprovação da reforma. Para isso, souberam tirar proveito de uma situação de crise setorial que, como toda crise, favorecia a emergência de soluções alternativas para a reformulação da política, e construíram a proposta de reforma durante mais de uma década mediante o desenvolvimento do seu referencial teórico, da divulgação de idéias e da articulação de apoiadores, pela constituição de uma comunidade epistêmica. No processo de construção da proposta da reforma, as idéias inovadoras foram, contudo, filtradas pelas instituições e práticas de saúde já consolidadas, sofrendo alterações sucessivas para acomodar as instituições vigentes e os interesses consolidados, de modo a influenciar a configuração da agenda reformista.

O processo de formação e de decisão da reforma refletiu também os efeitos das políticas anteriores sobre o processo político ao tornar evidentes as divergências prescritivas entre os diferentes atores. A definição da reforma da política conviveu com a manutenção dos arranjos previamente estabelecidos, demonstrando a influência dos interesses consolidados ao longo da trajetória da assistência. No momento da implementação da reforma, essas contradições se explicitaram, deixando evidente que a mudança institucional não caracterizara uma conjuntura crítica, no sentido de ter definido uma mudança de rota para a assistência à saúde. Além de não ser descontínua, a mudança institucionalizou a dupla trajetória, não apenas por meio de dispositivos do texto constitucional como também por meio daquilo que ele não explicitou, particularmente ao não regular a assistência privada nem definir o espaço de sua atuação em relação ao segmento público. Em termos legais, a escolha resultante do embate entre alternativas distintas, que expressavam as preferên- 
cias de dois conjuntos de atores, contemplou os dois ideários que se confrontaram durante o processo constituinte.

Essa explicação do caráter híbrido da reforma tem como suposto que as políticas de saúde funcionaram como variáveis dependentes, sendo, portanto, conseqüências da ação política, mas também como variáveis independentes ao explicarem o desenvolvimento político e as políticas posteriores em razão de seus efeitos institucionais. É esse duplo caráter que explica o formato híbrido da política de saúde definida por ocasião da reforma, conseqüência da sua própria trajetória, mas também trazendo elementos de inovação em razão de uma ação política organizada com vistas a um redesenho institucional.

Ao longo da trajetória da política de saúde, não apenas a ausência de expansão da rede pública de serviços de saúde e a baixa regulação dos prestadores privados vão desembocar em dificuldades concretas para a implementação do SUS na década de 90. Expressando o poder de veto dos interesses privados e do próprio governo, outras não-decisões terão efeitos similares, como a indefinição das fontes de custeio do SUS de forma a garantir recursos financeiros proporcionais à gradativa ampliação da cobertura pública e a ausência de regulação da assistência privada dos anos 60 até o final da década de 90. A instabilidade na alocação de recursos desde a reforma tem sugerido uma estratégia governamental de inviabilização sistêmica do sistema público, entendida como a utilização de mecanismos indiretos, em vez de propostas explícitas de redução programática dos objetivos do SUS.

Evidências desse argumento podem ser encontradas na análise do financiamento do SUS, caso em que a prática concreta tem negado constantemente os objetivos da reforma, culminando com a aprovação da Emenda Constitucional 29. Embora tenha como objetivo formal garantir fontes estáveis de financiamento, ao que tudo indica a EC 29 é mais uma forma legal, embora implícita, de reduzir ou, no mínimo, congelar os recursos federais destinados ao financiamento das ações e dos serviços de saúde, forçando a ampliação dos recursos alocados pelas instâncias subnacionais de governo em contexto de grave crise de financiamento das Unidades Federadas. O financiamento inadequado seria mais uma manifestação da inexistência de um consenso governamental no sentido de concretizar os princípios do SUS em sua completa acepção, sendo uma de suas expressões o conflito intraburocrático em torno 
da interpretação da base de cálculo das transferências federais, que tem se traduzido em prejuízos para o financiamento do setor.

A implantação do sistema de saúde de caráter universal coincide com a crise econômica e com o movimento de reforma do Estado. Esses processos trouxeram no seu bojo a difusão de propostas de redução da atuação do Estado, o questionamento de políticas de cunho universalista e a defesa da provisão privada de serviços sociais para aquelas categorias com capacidade de adquiri-los no mercado, com a correlata focalização dos gastos públicos nos segmentos mais pobres. É plausível supor que esse contexto político, econômico e ideológico causou novos problemas para a implementação da reforma sanitária e fragilizou o próprio ideário do SUS que confrontava com a nova agenda que se delineava para as políticas sociais, entre elas as de saúde. Além disso, o processamento da agenda reformista foi dificultado em razão das restrições à ampliação do gasto público em contexto de estabilização econômica. Entretanto, esses fatores econômicos e ideológicos, que são convergentes para o conjunto dos países latino-americanos, não são suficientes para explicar os processos de privatização na saúde, que assumiram feições diferentes e intensidades variadas.

No caso brasileiro, a expansão da assistência privada em detrimento da assistência pública não traduz um padrão de convergência na natureza e no conteúdo da reforma. Ao contrário, ela encontra explicação em fatores internos relacionados com a própria trajetória da política de saúde, na qual o timing da privatização foi muito anterior ao movimento de reforma do Estado. O crescimento do setor privado no Brasil, entendido tanto pela prestação de serviços por unidades privadas como pela existência de formas privadas de financiamento, gestão e acesso a serviços de saúde, foi aqui bem anterior ao movimento de valorização do mercado, fruto das reformas econômicas dos anos 90 , não podendo ser visto como uma resposta às mudanças na conjuntura nacional e internacional.

Mais do que isso, a reforma de cunho publicista e universal foi possível em um contexto de mudança política mais ampla, quando se abriu uma 'janela' política que permitiu a reforma da política de saúde em uma situação favorável a rupturas institucionais. No momento de implantação, contudo, fecha-se essa janela, e esse processo se dá simultaneamente à conformação de uma 
nova agenda, em situação de reconfiguração do Estado. A confluência desses processos vai definir os contornos da assistência no país, aprofundando as tendências históricas. Assim, a conjuntura dos anos 90 corroeu o ideário da reforma antes mesmo que ele tivesse sido capaz de alterar a forma de atuação governamental e a concepção pública de assistência construída historicamente.

Entretanto, apesar das restrições, o SUS se institucionalizou, na medida em que ocorreu de fato uma reorganização da assistência pública no país, inclusive com o reconhecimento público do direito à saúde. No processo de institucionalização, outros atores se constituíram e passaram a disputar espaço na arena decisória, particularmente os gestores municipais e estaduais, fortalecidos em razão do processo de descentralização, e os conselhos de saúde formados nos três níveis de governo como exigência da legislação. A mobilização em torno da viabilização financeira da assistência pública durante a década de 90 mostrou a visibilidade e a importância política que ela assumira, bem como a rede de instituições e atores constituída em torno do SUS, cujos interesses são diretamente afetados pela política de saúde, como os prestadores privados e profissionais de saúde, uma vez que a principal porta de entrada para a assistência é o sistema público.

A dupla trajetória da assistência à saúde no Brasil no período de quatro décadas se consolida no final da década de 90 com o estabelecimento da política regulatória voltada para o segmento privado. Essa regulação formalizou essa dualidade do ponto de vista legal, normativo e institucional, na medida em que os segmentos público e privado passaram a ser objeto da política de saúde de forma explícita e de modo a confirmar a independência entre as duas modalidades institucionais, a oposição entre os princípios norteadores de cada uma das formas de assistência, e a segmentação dos usuários. A adoção do instrumento de regulação na forma de uma agência reguladora revelou a influência dos modelos prescritivos vinculados às novas formas de intervenção do Estado na economia que têm acompanhado o movimento internacional de privatização. Diferentemente, no caso da saúde no Brasil, a regulação evidencia a ampliação da intervenção estatal em um mercado antes auto-regulado, com vistas a evitar as 'falhas de mercado', além de não substituir as formas tradicionais de intervenção direta. Ao contrário, o processo regulatório coincide com o aprofundamento da intervenção estatal no setor, sob a forma 
de financiamento, gestão e produção de serviços, que caracteriza o processo de implantação da reforma da política de saúde, baseada nos princípios da universalização e da responsabilidade governamental pela garantia do direito à saúde. As duas formas de intervenção são, ainda, vinculadas a mecanismos institucionais de tomada de decisão contraditórios que expressam pressupostos políticos diversos relativos à participação da sociedade nos processos decisórios e à responsabilização do Poder Público por meio de mecanismos de controle verticais.

Duas lógicas seguem operando na política de saúde que se expressam em uma forma contraditória de expansão da assistência. De um lado, uma lógica publicista, traduzida nos esforços de viabilizar o SUS, mesmo que voltado principalmente para os segmentos de menor poder aquisitivo, em um processo que, de certa forma, tornou-se irreversível. De outro lado, a lógica privatista, que tem como efeito a regulação do mercado, como forma de torná-lo mais eficiente, o que significa a ampliação da oferta e do consumo de planos e seguros de saúde.

O encadeamento de processos e ações de diferentes atores ao longo de quatro décadas levou à constituição de uma determinada configuração público/privado na assistência à saúde cuja característica mais marcante é o seu caráter segmentado. A consolidação da dupla trajetória da assistência se expressa nos dispositivos legais, na configuração da rede prestadora, no perfil dos usuários e nos instrumentos regulatórios.

De forma prospectiva, é possível especular sobre os desdobramentos da política de saúde brasileira com base nos componentes analíticos da interpretação que fizemos da sua trajetória. Na medida em que os efeitos de feedback das políticas prévias consolidaram um determinado padrão de assistência, na ausência de fatores que provoquem desequilíbrios nos arranjos moldados até agora, é pouco provável que a configuração institucional da assistência venha sofrer alterações relevantes. As possibilidades de reformulação institucional dependem de alterações no contexto mais amplo, político ou econômico, ou de crises internas que possam ser utilizadas como oportunidade por atores portadores de propostas alternativas. Embora do ponto de vista da racionalidade técnica seja possível pensar em outra configuração público/privado diferente da que prevalece no modelo brasileiro, não há indícios de pro- 
postas articuladas de um novo desenho para a política de assistência. Ou seja, a questão não está na agenda.

A dinâmica interna da própria política de saúde mostra várias contradições e estrangulamentos, muitos deles decorrentes da sua própria natureza dual, que produz numerosas ineficiências. Essa situação tende a produzir crises que, dependendo da forma como forem utilizadas pelos atores políticos, poderão abrir novas janelas políticas e levar a rupturas, mesmo que limitadas pelas políticas prévias. Se o modelo analítico admite a possibilidade de mudança, porém, o sentido dela é imprevisível. Porque se desenvolve uma dupla trajetória, é possível pensar em desdobramentos duplos ou diferentes alternativas na evolução da assistência, dependendo de que segmento vai encontrar condições mais favoráveis de desenvolvimento, uma vez que escolhas diferentes são sempre possíveis.

Entretanto, alguns indícios relativos ao comportamento do mercado permitem sugerir alguns desdobramentos possíveis. Em primeiro lugar, a regulação da assistência supletiva não tem levado à expansão do mercado, que se encontra em fase de quase estagnação ou, mesmo, de saturação. Em segundo, as agências reguladoras não têm conseguido corrigir as falhas do mercado, e o conflito relativo às regras não tem logrado construir um consenso. Por sua vez, o SUS avança no processo de institucionalização e tem se materializado em formatos institucionais que também vão fornecer a moldura em que se farão novas escolhas, decisões e políticas futuras em razão da constituição de interesses e atores. É possível especular que esses possam vir a dar maior sustentação política ao SUS em um quadro de restrições econômicas concretas para a expansão do segmento privado. Ou seja, da mesma forma que o modelo de política adotada no passado produziu instituições, legislação e interesses de forma a limitar as escolhas posteriores, também a dinâmica futura da política de saúde poderá ser afetada pelos efeitos institucionais da consolidação do SUS caso o segmento privado não encontre novas alternativas de expansão. Mas, na falta de fatores contingenciais que provoquem desequilíbrios e favoreçam inovações, e na inexistência de uma proposta inovadora articulada politicamente, a tendência será da inércia institucional. 


\section{Referências}

ABRUCIO, F. L. O impacto do modelo gerencial na administração pública: um breve estudo sobre a experiência internacional recente. Cadernos Enap, 10, 1997.

ABRUCIO, F. L. \& COSTA, V. M. F. Reforma do Estado e o contexto federativo brasileiro. Fundação Konrad-Adenauer-Stiftung, Pesquisa, 12, 1999.

ADVOCACIA GERAL DA UNIÃO. Parecer GM nº 16, 27 dez. 2000.

AGÊNCIA NACIONAL DE SAÚDE SUPLEMENTAR (ANS). Disponível em: <www.saude.gov.br.>. Acesso em: janeiro de 2003

AGÊNCIA NACIONAL DE SAÚDE SUPLEMENTAR (ANS). Regulação \& Saúde: estrutura, evolução e perspectivas da assistência médica suplementar. Rio de Janeiro: Ministério da Saúde, Agência Nacional de Saúde Suplementar, 2002.

AGUIAR, N. Modalidades assistenciais do Inamps. Revista de Administração Pública (RAP), 13(4): 117-135, 1979.

ALMEIDA, A. Interface e articulação entre o público e o privado no Sistema de Saúde Brasileiro. In: SIMPÓSIO REGULAMENTAÇÃO DOS PLANOS DE SAÚDE. Senado, 28 ago. 2001. Disponível em: <www.abramge.com.br>. Acesso em: 2002.

ALMEIDA, C. M. de. As Reformas Sanitárias dos Anos 80: crise ou transição?, 1995. Tese de Doutorado, Rio de Janeiro: Escola Nacional de Saúde Pública, Fundação Oswaldo Cruz.

ALMEIDA, C. M. de. Crise econômica, crise do Welfare State e reforma sanitária. In: GERSCHMAN, S. \& VIANNA, M. L. W. (Orgs.) A Miragem da PósModernidade: democracia e políticas sociais no contexto da globalização. Rio de Janeiro: Editora Fiocruz, 1997. 
ALMEIDA, C. M. de. O mercado privado de serviços de saúde no Brasil: panorama atual e tendências da assistência médica suplementar. Texto para Discussão, 599. Brasília: Ipea, nov. 1998.

ALMEIDA, M. H. T. Tendências Recentes da Negociação Coletiva no Brasil (Primeiras Idéias para Discussão). Rio de Janeiro: Instituto Latino-Americano de Desenvolvimento Econômico e Social, 1980.

ALMEIDA, M. H. T. \& MOYA, M. A reforma negociada: o Congresso e a política de privatização. Revista Brasileira de Ciências Sociais, 12(34): 119-132, 1997.

ANUÁRIO ESTATÍSTICO DE SAÚDE. Disponível em: <www.ans.gov.br>. Acesso em: 2001.

ARAÚJO, H. C. \& PIRES, J. C. L. Regulação e arbitragem nos setores de serviços públicos no Brasil: problemas e possibilidades. Revista de Administração Pública (RAP), 34(5): 9-28, 2000.

ARRETCHE, M. T. S. Emergência e desenvolvimento do Welfare State: teorias explicativas. Revista Brasileira de Informacãa Bibliográfica em Ciências Sociais, 39: 3-40, 1995.

ARTHUR, W. B. Competing technologies, increasing returns, and lock-in by historical events. Economic Journal, 99, 1989.

ASSOCIAÇÃO BRASILEIRA DE ECONOMIA DA SAÚDE (ABRES). In: ENCONTRO NACIONAL DE ECONOMIA DA SAÚDE, 1, 1994, São Paulo. Anais... São Paulo, 1994.

ASSOCIAÇÃO BRASILEIRA DAS EMPRESAS DE MEDICINA DE GRUPO (ABRAMGE). In: CONGRESSO ABRAMGE, 7, 1999. Anais... Disponível em: <www.abramge.com.br>. Acesso em: 2002.

ASSOCIAÇÃO MÉDICA BRASILEIRA (AMB). Disponível em: <www.amb.org.br>. Acesso em: 2002.

AZEVEDO, S. de. Reforma do Estado e mudança institucional: variáveis exógenas e endógenas. In: SEMINÁRIO INTERNACIONAL A REFORMA DA ADMINISTRAÇÃO PÚBLICA NO BRASIL: POSSIBILIDADES E OBSTÁCULOS. Fundação Joaquim Nabuco e Escola de Governo do Estado de Pernambuco. Recife, 20 e 21 de agosto de 1998.

AZEVEDO, S. de \& MELO, M. A. A política da reforma tributária: federalismo e mudança constitucional. Revista Brasileira de Ciências Sociais (RBCS), 12(35): 75-99, 1997.

BACHA, E. L.; MATTA, M. \& MONDANESI, R. L. Encargos Trabalbistas e Absorção de Mão-de-Obra. Rio de Janeiro: Ipea, 1972.

BACHRACH, P. \& BARATZ, M. S. Two faces of power. The American Political Science Review, 56, 1962. 
BAHIA, L. Oferta e Produção de Serviços de Saúde no Brasil na Década de 80: um estudo exploratório, 1991. Dissertação de Mestrado, Rio de Janeiro: Escola Nacional de Saúde Pública, Fundação Oswaldo Cruz.

BAHIA, L. Planos e Seguros Saúde: padrões e mudanças das relações entre o público e o privado no Brasil, 1999. Tese de Doutorado, Rio de Janeiro: Escola Nacional de Saúde Pública, Fundação Oswaldo Cruz.

BAHIA, L. \& VIANA, A. L. Introdução. In: MINISTÉRIO DA SAÚDE. Regulação ¿ Saúde: estrutura, evolução e perspectivas da assistência médica suplementar/Ministério da Saúde, Agência Nacional de Saúde Suplementar. Rio de Janeiro: ANS, 2002.

BALDWIN, R.; SCOTT, C. \& HOOD, C. A Reader on Regulation. New York: Oxford University Press, 1998.

BARROCA DE ANDRÉA, J. L. Prefácio. In: MINISTÉRIO DA SAÚDE. Regulação \& Saúde: estrutura, evolução e perspectivas da assistência médica suplementar/ Ministério da Saúde, Agência Nacional de Saúde Suplementar. Rio de Janeiro: ANS, 2002.

BASTOS, M. V. Saúde e Previdência Social no Brasil: o impacto da Previdência Social na organização dos serviços médicos. Revista de Administração Pública (RAP), 13(4): 95-116, 1979.

BECKER, G. A theory of competition among pressure groups for political influence. Quarterly Journal of Economics, 98: 371-400, 1983.

BOSCHI, R. Governança, participação e eficiência das políticas públicas: exame de experiências municipais no Brasil. In: MELO, M. A. (Org.) Reforma do Estado e Mudança Institucional no Brasil. Recife: Fundação Joaquim Nabuco, Escola de Governo e Políticas Públicas, Massangana, 1999.

BOSCHI, R. \& LIMA, M. R. S. O Executivo e a construção do Estado no Brasil: do desmonte da Era Vargas ao novo intervencionismo regulatório. In: VIANNA, L. W. A Democracia e os Três Poderes no Brasil. Belo Horizonte, Rio de Janeiro: Editora UFMG, Iuperj, Faperj, 2002.

BRAGA, J. C. de S. \& PAULA, S. G. de. Saúde e Previdência: estudos de politica social. São Paulo: Cebes, Hucitec, 1981.

BRASIL. Constituição de 1988. 27. ed. atualizada e ampliada. São Paulo: Saraiva, 2001.

BRASIL. Emenda Constitucional n 29, 13 out. 2000 (EC 29/2000).

BRASIL. Lei $\mathrm{n}^{\circ}$ 9.656/98. Dispõe sobre os planos e seguros privados de assistência à saúde.

BRASIL. Medidas provisórias que alteram a Lei no 9.656/98, que dispõe sobre os planos privados de assistência à saúde e dá outras providências.

BRESSER PEREIRA, L. C. Crise Econômica e Reforma do Estado no Brasil. São Paulo: Editora 34, 1996 . 
BRESSER PEREIRA, L. C. Da administração pública burocrática à gerencial. Revista do Serviço Público, 120(1): 7-40, 1996b.

BRESSER PEREIRA, L. C. A Reforma do Estado dos Anos 90: lógica e mecanismos de controle. Brasília: Ministério da Administração Federal e Reforma do Estado, 1997.

BRESSER PEREIRA, L. C. Reforma administrativa do sistema de saúde. Cadernos Mare da Reforma de Estado, 13. Brasília: Ministério da Administração Federal e Reforma do Estado (Mare), 1998a.

BRESSER PEREIRA, L. C. A reforma da saúde. Cadernos Mare da Reforma de Estado, 13. Brasília: Ministério da Administração Federal e Reforma do Estado (Mare), 1998b.

CÂMARA DOS DEPUTADOS. Departamento de Taquigrafia, Revisão e Redação. Notas taquigráficas relativas às Reuniões Ordinárias da Comissão Especial - PEC 82-A/95 Recursos para o SUS. Datas das reuniões: 20/5/ 1998; 26/5/1998; 2/6/1998; 16/6/1998; 17/6/1998; 24/6/1998; 30/6/ $1998 ; 1^{\circ} / 7 / 1998$.

CÂMARA DOS DEPUTADOS. Departamento de Taquigrafia, Revisão e Redação. Notas taquigráficas relativas à Audiência Pública na Comissão Especial - PEC 82-A/95 Recursos para o SUS. Data: 27/5/1998.

CÂMARA DOS DEPUTADOS. Departamento de Taquigrafia, Revisão e Redação. Notas taquigráficas da Sessão Ordinária da Câmara dos Deputados de $8 / 5 / 2001$.

CÂMARA DOS DEPUTADOS. Notas taquigráficas relativas às Audiências Públicas na Comissão Especial de Planos de Saúde. Departamento de Taquigrafia, Revisão e Redação. Datas das audiências: 9/10/1996; 15/10/ 1996; 22/10/1996; 29/10/1996; 19/11/1996; 3/12/1996; 25/2/1997; 12/3/1997; 18/3/1997.

CÂMARA DOS DEPUTADOS. Diário da Câmara dos Deputados. Datas pesquisadas: 22/5/1993; 10/9/1993; 4/3/1994; 29/3/1994; 30/4/1994; 10/6/1994; 28/6/1994; 29/6/1994; 15/3/1995; 3/6/1995; 16/8/1995; $29 /$ $8 / 1995 ; 18 / 10 / 1995 ; 24 / 11 / 1995 ; 3 / 2 / 1995 ; 7 / 2 / 1996 ; 26 / 3 / 1996 ; 19 /$ 4/1996; 20/4/1996; 25/6/1996; 6/7/1996; 19/7/1996; 8/10/1996; 27/6/ 1997; 14/8/1997; 11/9/1997; 17/9/1997; 18/9/1997; 25/9/1997; 26/9/ 1997; 2/10/1997; 8/10/1997; 9/10/1997; 8/10/1997; 10/10/1997; 15/10/ 1997; 16/10/1997; 18/10/1997; 16/10/1998; 28/10/1999; 11/11/1999.

CÂMARA DOS DEPUTADOS. Jornal da Câmara, 3 set. 2001.

CÂMARA DOS DEPUTADOS. Consultoria de Orçamento e Fiscalização Financeira, Núcleo de Saúde. Estudo $n^{\circ} 2$, de 2000 - NS. Recursos mínimos para a Saúde em 2000 e 2001. 
CÂMARA DOS DEPUTADOS. Consultoria de Orçamento e Fiscalização Financeira, Núcleo de Saúde. Estudo n 84, de 2001 - NS. EC n ${ }^{\circ} 29$ de 2000: valor mínimo a ser aplicado em ações e serviços públicos de saúde interpretações controversas e suas implicações no orçamento da União.

CÂMARA DOS DEPUTADOS/CONSULTORIA DE ORÇAMENTO E FISCALIZAÇÃO FINANCEIRA/NÚCLEO DE SAÚDE. Estudo $n^{\circ} 2$, 2000 - NS. Recursos mínimos para a Saúde em 2000 e 2001. Brasília: Câmara dos Deputados, 2000.

CÂMARA DOS DEPUTADOS/CONSULTORIA DE ORÇAMENTO E FISCALIZAÇÃO FINANCEIRA/NÚCLEO DE SAÚDE. Estudo $n^{\circ} 84$. Brasília: Câmara dos Deputados, 2000.

CAMPOS, G. W. S. A reforma sanitária necessária. In: BERLINGUER, G.; TEIXEIRA, S. F. \& CAMPOS, G. W. S. Reforma Sanitária Itália e Brasil. São Paulo: Cebes, Hucitec, 1988.

CARDOSO, F. H. O Modelo Político Brasileiro. São Paulo, Rio de Janeiro: Difel, 1979.

CARNEIRO, V. B. Gênese da Assistência Supletiva de Saúde no Brasil, 2001. Dissertação de Mestrado, Belo Horizonte: Faculdade de Medicina, Universidade Federal de Minas Gerais.

CARVALHO, G. C. M. Depoimento. In: GOULART, F. A. de A. Municipalização: veredas - caminhos do Movimento Municipalista de Saúde no Brasil. Rio de Janeiro: Abrasco, Conasems, 1996.

CHECCIA, C. M. A Assistência Médica como um Benefício nas Empresas: um estudo em organiz̧ações de grande porte da cidade de São Paulo, 1996. Dissertação de Mestrado, São Paulo: Escola de Administração de Empresas de São Paulo, Fundação Getúlio Vargas.

COHN, A. Previdência Social e Processo Politico no Brasil. São Paulo: Moderna, 1981.

COHN, A. Caminhos da reforma sanitária. Lua Nova, 19: 171-188, 1989.

COHN, A. A saúde na Previdência Social: antigos estigmas e novos desafios. In: COHN, A. \& ELIAS, P. E. Saúde no Brasil: políticas e organização de serviços. São Paulo: Cortez, 1996.

COLLIER, D. \& COLLIER, R. Shaping the Political Arena. Princeton: Princeton University Press, 1991.

COMISSÃO DE DEFESA DO CONSUMIDOR, MEIO AMBIENTE E MINORIAS. Relatório sobre o Projeto de Lei n ${ }^{\circ} 4.425 / 1994$, deputada Laura Carneiro, 1\%7/1995.

COMISSÃO DE DEFESA DO CONSUMIDOR, MEIO AMBIENTE E MINORIAS. Primeiro substitutivo oferecido pela relatora, deputada Laura Carneiro, ao Projeto de Lei $n^{\circ} 4.425 / 1994,1^{\circ} / 9 / 1995$. 
COMISSÃO DE DEFESA DO CONSUMIDOR, MEIO AMBIENTE E MINORIAS. Segundo substitutivo oferecido pela relatora, deputada Laura Carneiro, ao Projeto de Lei no 4.425/1994, 11/10/1995.

COMISSÃO DE SEGURIDADE SOCIAL E FAMÍLIA. Substitutivo ao Projeto de Lei n ${ }^{\circ} 4.425 / 1994$, apresentado pelo relator, deputado Iberê Ferreira, em 6/12/1995.

COMISSÃO DE SEGURIDADE SOCIAL E FAMÍLIA. Voto em separado dos deputados Eduardo Jorge, José Augusto, Marta Suplicy e Humberto Costa, rejeitando o substitutivo ao Projeto de Lei n ${ }^{\circ} 4.425 / 1994$, aprovado pela Comissão em 13/12/1995.

COMITÊ DE INTEGRAÇÃO DAS ENTIDADES FECHADAS DE ASSISTÊNCIA À SAÚdE (CIEFAS). A História da Autogestão no Brasil. São Paulo: Ciefas, 2000.

CONSELHO FEDERAL DE MEDICINA. Resolução CFM n 1.401/93.

CONSELHO FEDERAL DE MEDICINA. Resolução CFM nº 1.642/2002.

CONSELHO NACIONAL DE SAÚDE (CNS). Ata de Reunião Ordinária, 15 e $16 / 3 / 2000$.

CONSELHO NACIONAL DE SAÚDE (CNS). Parâmetros consensuais sobre a implementação e regulamentação da Emenda Constitucional 29. Grupo de Trabalho: CNS/MS-SIS/MS-CAS/Senado Federal-CSSF/Câmara Federal-MP-Atricon-Conass-Conasems. Brasília, jun. 2001.

CONSELHO NACIONAL DE SAÚDE (CNS). Moção n 4, de 6/9/2001.

CONSELHO NACIONAL DE SAÚDE (CNS). Disponível em: <www.conselho.saúde.gov.br>. Acesso em: 2002.

CORDEIRO, H. A. Sistemas de saúde: o Estado e a democratização da saúde. Revista de Administração Pública (RAP), 13(4): 39-62, 1979.

CORDEIRO, H. A. As Empresas Médicas: as transformações capitalistas da prática médica. Rio de Janeiro: Graal, 1984.

COSTA, N. do R. Políticas públicas, diretos e interesses: reforma sanitária e organização sindical no Brasil. In: EIBENSCHUTZ, C. (Org.) Política de Saúde: o público e o privado. Rio de Janeiro: Editora Fiocruz, 1995.

COSTA, N. do R. Políticas Públicas, Justiça Distributiva e Inovação: saúde e saneamento na agenda social. São Paulo: Hucitec, 1998.

COSTA, N. do R. \& RIBEIRO, J. M. A política regulatória e o setor saúde: nota sobre o caso brasileiro. In: SIMPÓSIO REGULAMENTAÇÃO DOS PLANOS DE SAÚDE, 28 e 29 de agosto de 2001. Textos de referência. Brasília: Ministério da Saúde, Conselho Nacional de Saúde, 2001. 
DAIN, S.; QUADROS, W. L. \& CAVALCANTI, C. E. G. Renúncia fiscal e assistência suplementar. In: MINISTÉRIO DA SAÚDE. Regulação \& Saúde: estrutura, evolução e perspectivas da assistência médica suplementar/Ministério da Saúde, Agência Nacional de Saúde Suplementar. Rio de Janeiro: ANS, 2002.

DÂMASO, R. Saber e práxis na reforma sanitária: avaliação da prática científica no movimento sanitário. In: TEIXEIRA, S. F. (Org.) Reforma Sanitária: em busca de uma teoria. São Paulo, Rio de Janeiro: Cortez, Abrasco, 1989.

DIÁRIO DA ASSEMBLÉIA NACIONAL CONSTITUINTE (DANC). Datas: 17/7/1987, 18/7/1987.

DIÁRIO OFICIAL DA UNIÃO (DOU). 18/12/2001. Retificação Parecer AGU $\mathrm{n}^{\circ} 016$ de $27 / 12 / 2000$.

DINIZ, E. Governabilidade, democracia e reforma do Estado: os desafios da construção de uma nova ordem no Brasil dos anos 90. Dados, 38(3): 385415, 1995a.

DINIZ, E. Crise, governabilidade e reforma do Estado: em busca de um novo paradigma. In: GERSCHMAN, S. \& VIANNA, M. L. W. (Orgs.) A Miragem da Pós-Modernidade: democracia e políticas sociais no contexto da globalização. Rio de Janeiro: Editora Fiocruz, 1995b.

DINIZ, E. Crise, Reforma do Estado e Governabilidade: Brasil, 1985-95. Rio de Janeiro: Editora Fundação Getúlio Vargas, 1997.

DINIZ, E. Globalização, reforma do Estado e teoria democrática contemporânea. São Paulo em Perspectiva, 15(4): 13-22, 2001.

DONNANGELO, M. C. F. Medicina e Sociedade: o médico e seu mercado de trabalho. São Paulo: Pioneira, 1975.

DONER, R. \& SCHNEIDER, B. R. The new economic institutionalism, business associations and development. Working Paper. Genebra: International Institute for Labour Studies, 1999.

DRAIBE, S. M. Repensando a política social: dos anos 80 ao início dos 90. In: SOLA, L. \& PAULANI, L. M. (Orgs.) Lições da Década de 80. São Paulo: Edusp, Unrisd, 1995.

EIBENSCHUTZ, C. Apresentação. In: EIBENSCHUTZ, C. (Org.) Politica de Saúde: o público e o privado. Rio de Janeiro: Editora Fiocruz, 1995.

ESCOREL, S. Reviravolta na Saúde: origem e articulação do movimento sanitário. Rio de Janeiro: Editora Fiocruz, 1998.

ESPING-ANDERSEN, G. The Three Worlds of Welfare State Capitalism. New Jersey: Princeton University Press, 1990.

EVANS, P. B.; RUESCHEMEYER, D. \& SKOCPOL, T. (Ed.) Bringing the State back in. Cambridge: Cambridge University Press, 1985. 
FARIA, C. A. P. Uma genealogia das teorias e modelos do Estado de Bem-Estar Social. Revista Brasileira de Informação Bibliográfica em Ciências Sociais, 46, 1998.

FARIAS, P. C. L. \& RIBEIRO, S. M. R. Regulação e os novos modelos de gestão no Brasil. Revista do Serviço Público, ano 53, 3, 2002.

FAVERET, P. F. \& OLIVEIRA, P. J. de. A universalização excludente: reflexões sobre as tendências do sistema de saúde. Dados - Revista de Ciências Sociais, 33(2): 257-283, 1990.

FEDERAÇÃO NACIONAL DAS EMPRESAS DE SEGURO PRIVADO (FENASEG). Disponível em: <www.fenaseg.org.br>. Acesso em: 21 out. 2002.

FEDERAÇÃO BRASILEIRA DE HOSPITAIS (FBH). Disponível em: <www.fbh.com.br>. Acesso em: 8 nov. 2002.

FESSEL, E. Assistência hospitalar própria e contratada do Instituto Nacional de Previdência Social. Revista Paulista de Hospitais, 25: 1, jan. 1977.

FIGUEIREDO, A. C. \& LIMONGI, F. Executivo e Legislativo na Nova Ordem Constitucional. Rio de Janeiro: Editora Fundação Getúlio Vargas, 1999.

FIOCRUZ/CFM. Pesquisa Perfil dos Médicos no Brasil, 1995.

FLEURY, S. Paradigmas da reforma da seguridade social: liberal produtivista versus universal publicista. In: EIBENSCHUTZ, C. (Org.) Politica de Saúde: o público e o privado. Rio de Janeiro: Editora Fiocruz, 1995.

FLEURY, S. A questão democrática na saúde. In: FLEURY, S. (Org.) Saúde e Democracia: a luta do Cebes. São Paulo: Lemos Editorial, 1997.

FLEURY, S. Universal, dual or plural? Health care models and issues in Latin America. In: MOLINA, C. G. \& ARCO, J. N. (Orgs.) Health Services in Latin America and Asia. Washington D. C., 2001. Disponível em: <www.ebape.fjv.br/ academico/asp/dsp_professor.asp?cd_pro $=36>$.

FOLHA DE S.PAULO. 19 jan. 1997.

FUNDAÇÃO DE SEGURIDADE SOCIAL (GEAP). Os dilemas em torno da Patronal. Jornal da Patronal, ano II, 3, 1990.

FUNDAÇÃO DE SEGURIDADE SOCIAL (GEAP). Disponível em: <www.geap.com.br>. Acesso em: 6 maio. 2002.

FUNDAÇÃO JOÃO PINHEIRO. Gasto Federal com Assistência à Saúde em Minas Gerais: um estudo sobre a desigualdade na distribuição dos recursos financeiros. Belo Horizonte: Fundação João Pinheiro, 1997.

FUNDAÇÃO JOÃO PINHEIRO. Descentralização e Governança no Setor Saúde em Belo Horizonte. Belo Horizonte: Fundação João Pinheiro, 1998.

FUNDAÇÃO JOÃO PINHEIRO. A Reforma do Sistema de Saúde do Brasil: a descentralização como diretriz e a igualdade como princípio. Belo Horizonte: Fundação João Pinheiro, 1999. 
GALLO, E. \& NASCIMENTO, P. C. Hegemonia, bloco histórico e movimento sanitário. In: TEIXEIRA, S. F. (Org.). Reforma Sanitária: em busca de uma teoria. São Paulo, Rio de Janeiro: Cortez, Abrasco, 1989.

GENTILE DE MELO, C. A medicina previdenciária. In: GUIMARÃES, R. (Org.) Saúde e Medicina no Brasil: contribuição para um debate. Rio de Janeiro: Graal, 1984.

GERSCHMAN, S. A Democracia Inconclusa: um estudo da reforma sanitária brasileira. Rio de Janeiro: Editora Fiocruz, 1995.

GIFFONI, R. M. Assistência Médica e as Relações de Trabalho na Empresa: o modelo de convênio com a Previdência Social, 1991. Dissertação de Mestrado, São Paulo: Universidade de São Paulo.

GIOVANELlA, L.; RIBEIRO, J. M. \& COSTA, N. do R. Defesa dos consumidores e regulação dos planos de saúde. In: MINISTÉRIO DA SAÚDE. Regulação \& Saúde: estrutura, evolução e perspectivas da assistência médica suplementar/Ministério da Saúde, Agência Nacional de Saúde Suplementar. Rio de Janeiro: ANS, 2002.

GOMÀ, R. \& SUBIRATS, J. Políticas públicas: hacia la renovación del instrumental de análisis. In: GOMÀ, R. \& SUBIRATS, J. (Orgs.) Políticas Públicas en España: contenidos, rede de actores y niveles de gobierno. Barcelona: Ariel, 1998.

GOODIN, R. E. The Theory of Institutional Design. Cambridge: Cambridge University Press, 1996.

GOULART, F. A. de A. Municipalização: veredas - caminhos do movimento municipalista de saúde no Brasil. Rio de Janeiro: Abrasco, Conasems, 1996.

GOULART, F. A. de A. Os médicos e a saúde no Brasil: enfrentando os dilemas de uma transição múltipla e complexa. In: GOULART, F. A. de A. \& CARVALHO, G. de (Orgs.). Os Médicos e a Saúde no Brasil. Brasília: Conselho Federal de Medicina, 1998.

GOUREVITCH, P. Politics in Hard Times: comparative responses to international economic crisis. Ithaca: Cornell University Press, 1986.

HALL, P. A. e TAYLOR, R. C. R. Political science and the three new institutionalisms. Political Studies, 44(5): 936-957, 1996.

HATTAM, V. C. Labor Visions and State Power: the origins of business unionism in the United States. Princeton: Princeton University Press, 1993.

HECLO, H. Modern Social Policies in Britain and Sweden. New Haven, Conn: Yale University Press, 1974.

HOCHMAN, G. A Era do Saneamento. São Paulo: Hucitec, Anpocs, 1998.

IMMERGUTT, E. M. The rules of the game: the logic of health policy-making in France, Switzerland and Sweden. In: STEINMO, S.; THELEN, K. \& LONSTRETH, F. (Ed.) Structuring Politics: historical institutionalism in comparative analysis. Cambridge: Cambridge University Press, 1992. 
JEPPERSON, R. L. Institutions, institutional effects, and institutionalism. In: POWELL, W. W. \& DIMAGGIO, P. J. The New Institutionalism in Organizational Snalysis. Chicago, Londres: University of Chicago Press, 1991.

JORNAL DO BRASIL. 28 ago. 2001.

JORNAL FBH, anos 2000, 2001, 2002. Disponível em: <www.fbh.gov.br> Acesso em: 2002.

LABRA, M. E. As políticas de daúde no Chile: entre a razão e a força. In: LABRA, M. E. \& BUSS, P. M. (Orgs.) Sistemas de Saúde: continuidades e mudanças. São Paulo, Rio de Janeiro: Hucitec, Editora Fiocruz, 1995.

LABRA, M. E. \& BUSS, P. M. (Orgs.) Sistemas de Saúde: continuidades e mudanças. São Paulo, Rio de Janeiro: Hucitec, Editora Fiocruz, 1995.

LAURELL, A. C. La lógica de la privatizacion en salud. In: EIBENSCHUTZ, C. (Org.) Política de Saúde: o público e o privado. Rio de Janeiro: Editora Fiocruz, 1995.

LEVCOVITZ, E. Transição $\times$ Consolidação: um estudo sobre as reformas das politicas nacionais de saúde - 1974/1996, 1997. Tese de Doutorado, Rio de Janeiro: Instituto de Medicina Social, Universidade do Estado do Rio de Janeiro.

LOPES, J. R. B. Novos parâmetros para a reorganização da política social brasileira. In: IPEA. Textos para Discussão, 358, dez. 1994.

LUCCHESI, P. T. R. Descentralização do financiamento e gestão da assistência à saúde no Brasil: a implementação do Sistema Único de Saúde retrospectiva 1990/1995. Planejamento e Políticas Públicas, 14, dez. 1996.

LUZ, M. T. As Instituições Médicas no Brasil: instituições e estratégia de hegemonia. 3. ed. Rio de Janeiro: Graal, 1986.

MAJONE, G. Do estado positivo ao estado regulador: causas e conseqüências de mudanças no modo de governança. Revista do Serviço Público, ano 50, 1, 1999.

MALLOY, J. M A política de Previdência Social no Brasil: participação e paternalismo. Revista Dados, 13: 125-139, 1976.

MALLOY, J. M. Politica de Previdência Social no Brasil. Rio de Janeiro: Graal, 1986.

MARCH, J. G. \& OLSEN, J. P. The new institutionalism: organizational factors in political life. The American Political Science Review, 78(3): 734-749, 1984.

MARCH, J. G. \& OLSEN, J. P. Rediscovering Institutions: the organizational basis of politics. New York: The Free Press, 1989.

MÉDICI, A. C. O setor privado prestador de serviços de saúde no Brasil: dimensão, estrutura e funcionamento. Relatórios Técnicos, 2/90. Brasília: Instituto Brasileiro de Geografia e Estatística (IBGE), Escola Nacional de Ciências Estatísticas (Ence), maio. 1990. 
MÉDICI, A. C. Os serviços de assistência médica das empresas: evolução e tendências recentes. Relatórios técnicos, 2/92. Rio de Janeiro: Instituto Brasileiro de Geografia e Estatística (IBGE), Escola Nacional de Ciências Estatísticas (Ence), dez. 1991a.

MÉDICI, A. C. A Medicina de Grupo no Brasil. Rio de Janeiro: Organização PanAmericana da Saúde (Opas), 1991 b.

MÉDICI, A. C. Incentivos Governamentais ao Setor Privado em Saúde no Brasil. Rio de Janeiro: Escola Nacional de Ciências Estatísticas (Ence), 1991c.

MÉDICI, A. C. Perspectivas do Financiamento à Saúde no Governo Collor de Mello. Brasília: Opas/OMS, 1991d. (Série Economia e Financiamento, 2)

MELO, C. G. O Sistema de Saúde em Crise. 2. ed. São Paulo: Cebes, Hucitec, 1981.

MELO, M. A. Governance e reforma do Estado: o paradigma do agente X principal. RSP, Revista do Serviço Público, ano 47, 120(1): 67-82, 1996.

MELO, M. A. (Org.) Reforma do Estado e Mudança Institucional no Brasil. Recife: Fundação Joaquim Nabuco, Escola de Governo e Políticas Públicas, Massangana, 1999.

MELO, M. A. Política regulatória: uma revisão da literatura. Revista Brasileira de Informação Bibliográfica em Ciências Sociais, 50: 7-43, 2000.

MELO, M. A. A política da ação regulatória: responsabilização, credibilidade e delegação. Revista Brasileira de Ciências Sociais (RBCS), 16(46): 55-68, 2001.

MENDES, E. V. As políticas de saúde no Brasil nos anos 80: a conformação da reforma sanitária e a construção do projeto neoliberal. In: MENDES, E. V. (Org.) Distrito Sanitário: o processo social de mudança das práticas sanitárias do Sistema Único de Saúde. São Paulo, Rio de Janeiro: Hucitec, Abrasco, 1993.

MENDES, E. V. Uma Agenda para a Saúde. São Paulo: Hucitec, 1996.

MENDES, E. V. Os Grandes Dilemas do SUS. Salvador: Casa da Qualidade Editora, 2001.

MENICUCCI, T. M. G. Previdência Privada: a negação/complementação da Previdência Social Pública, 1990. Dissertação de Mestrado, Belo Horizonte: Faculdade de Filosofia e Ciências Humanas, Universidade Federal de Minas Gerais.

MENICUCCI, T. M. G. Assistência Patronal: a negação da previdência social no seu próprio seio, 1987. Belo Horizonte: Departamento de Sociologia e Antropologia, Faculdade de Filosofia e Ciências Humanas, Universidade Federal de Minas Gerais, 1987. (Mimeo.)

MENiCUCCI, T. M. G. Público e Privado na Política de Assistência à Saúde no Brasil: atores, processo e trajetória, 2003. Tese de Doutorado, Belo Horizonte: Faculdade de Filosofia e Ciências Humanas, Universidade Federal de Minas Gerais. 
MESQUITA, M. A. F. de. A regulação da assistência suplementar à saúde. In: MINISTÉRIO DA SAÚDE. Regulação \& Saúde: estrutura, evolução e perspectivas da assistência médica suplementar/Ministério da Saúde, Agência Nacional de Saúde Suplementar. Rio de Janeiro: ANS, 2002.

MINISTÉRIO DA FAZENDA. Secretaria Executiva/Subsecretaria de Assuntos Administrativos. Ações e Serviços Públicos de Saúde: Emenda Constitucional n' 29/2000 - Evolução 1999/2002.

MINISTÉRIO DA FAZENDA. Secretaria Executiva/Subsecretaria de Assuntos Administrativos. SRF/Coordenação Geral de Política Tributária. Demonstrativo dos Beneficios Tributários - 2003.

MINISTÉRIO DA FAZENDA/SECRETARIA DA RECEITA FEDERAL. Análise Econômica da Declaração do IRPF 99. Estudos Tributários (s/d).

MINISTÉRIO DA FAZENDA/SECRETARIA DA RECEITA FEDERAL. Consultoria Jurídica. Aplicação da Emenda Constitucional n 29: relativa a recursos minimos para o setor saúde. Parecer/Conjur/MS/EL n 847/2000.

MINISTÉRIO DA FAZENDA/SECRETARIA DA RECEITA FEDERAL. Procuradoria Geral da Fazenda Nacional/Coordenação Geral de Assuntos Financeiros. Parecer PGFN/CAF $n^{\circ}$ 2561/2000.

MINISTÉRIO DA FAZENDA/SECRETARIA DA RECEITA FEDERAL. Subsecretaria de Planejamento e Orçamento. Nota $n^{\circ}$ 05/SPO/MS. Brasília, 18 dez. 2000.

MINISTÉRIO DA FAZENDA/SECRETARIA DA RECEITA FEDERAL. Gabinete do Ministro. Exposição de Motivos nº 022/GM/MS, 23 fev. 2001.

MINISTÉRIO DA FAZENDA/SECRETARIA DA RECEITA FEDERAL. Ofício MS/SE/GAB n 840, 24 abr. 2001.

MINISTÉRIO DA FAZENDA/SECRETARIA DA RECEITA FEDERAL. Nota/Conjur/MS nº 001/2001.

MINISTÉRIO DA FAZENDA/SECRETARIA DA RECEITA FEDERAL. Secretaria Executiva/Subsecretaria de Assuntos Administrativos. Relatório do Seminário A Operacionalização da Emenda Constitucional 29. Brasília, 19, 20 e 21 set. 2001.

MINISTÉRIO DA FAZENDA/SECRETARIA DA RECEITA FEDERAL. Secretaria Executiva/Subsecretaria de Assuntos Administrativos. Relatório do $2^{\circ}$ Seminário A Operacionalização da Emenda Constitucional 29, Brasília, 5 e 6 dez. 2001.

MINISTÉRIO DA FAZENDA/SECRETARIA DA RECEITA FEDERAL. Consolidação da Declaração de Imposto de Renda das Pessoas Físicas - 2001. Brasília: out. 2002. (Estudos Tributários, 11) 
MINISTÉRIO DA FAZENDA/SECRETARIA DA RECEITA FEDERAL. Secretaria Executiva/Subsecretaria de Planejamento e Orçamento. Emenda Constitucional $n^{\circ}$ 29/2000: interpretação, implementação e regulamentação (dossiê). Brasília: Ministério da Saúde, 2002.

MINISTÉRIO DA FAZENDA/SECRETARIA DA RECEITA FEDERAL. Disponível em: <www.receita.fazenda.gov.br>.

MINISTÉRIO DA SAÚDE. 1997 - O Ano da Saúde no Brasil: ações e metas prioritárias. Brasília: Ministério da Saúde, 1997.

MINISTÉRIO DA SAÚDE. Anuário Estatístico de Saúde do Brasil, 2001. Disponível em: < portal.saude.gov.br/saude/aplicacoes/anuario2001/introd.cfm>. Acesso em: 2002.

MINISTÉRIO DA SAÚDE. Disponível em:<www.saude.gov.br>.

MINISTÉRIO DA SAÚDE/SECRETARIA DE GESTÃO DE INVESTIMENTOS EM SAÚDE. Estimativas de Impacto da Vinculação Constitucional de Recursos para a Saúde (Emenda Constitucional n² 29/2000). Elaboração de Ana Cecília de Sá Campello Faveret et al. Brasília: Ministério da Saúde, 2001. (Série J. Cadernos, 4)

MINISTÉRIO DA SAÚDE/GABINETE DO SECRETÁRIO-EXECUTIVO. Ofício MS/SE/GAB n 840. Brasília, 24 abr. 2001.

MINISTÉRIO DA SAÚDE/CONSELHO NACIONAL DE SAÚDE. In: SIMPÓSIO REGULAMENTAÇÃO DOS PLANOS DE SAÚDE, 28 e 29 ago. 2001. Textos de referência. Brasília: Ministério da Saúde, 2001.

MINISTÉRIO DA SAÚDE/SECRETARIA DE ASSISTÊNCIA À SAÚDE. Caderno da SAS: orientaçoes para compra de serviços de saúde. Brasília: Ministério da Saúde, 2001.

MINISTÉRIO DA SAÚDE/SECRETARIA EXECUTIVA/SUBSECRETARIA DE ASSUNTOS ADMINISTRATIVOS. Ações e Serviços Públicos de Saúde. Emenda Constitucional no 29/2000 - Evolução 1999/2002.

MOE, T. The positive theory of public bureaucracy. In: MUELLER, D. (Ed.) Perspectives on Public Choice: a handbook. Cambridge: Cambridge University Press, 1997.

MONTONE, J. Saúde suplementar e as ferramentas gerenciais do futuro. In: CONFERENCIA BRASILEIRA DE SEGUROS, RESSEGUROS, PREVIDÊNCIA PRIVADA E CAPITALIZAÇÃO (CONSEGURO). Rio de Janeiro, 12 set. 2000.

MONTONE, J. Regulação dos planos privados de assistência à saúde pela ANS: avaliação, perspectivas e interfaces SUS-saúde suplementar. Palestra proferida no Conselho Nacional de Saúde, 6 jun. 2001. 
MONTONE, J. Palestra proferida no painel "Tendências globais na área da saúde", dentro do tema "Visão brasileira", em encontro da Abramge, $23 / 11 / 2001$.

MÜLLER, J. S. Políticas de saúde no Brasil: a descentralização e seus atores. Revista Saúde em Debate, 31, 1991.

MUSGROVE, P. Public and private roles in health: theory and financing patterns. World Bank Discussions Paper, 339. Washington, D.C.: The World Bank, 1996.

NOLL, R. G. Economic perspectives on the politics of regulation. In: SCHMALENSEE, R. \& WILLIG, R. D. (Eds.) Handbook of Industrial Organization. v. 2. Amsterdã: Elsevier Science Publisher, 1989.

NORTH, D. Institutions, Institutional Change and Economics Performance. Cambridge: Cambridge University Press: 1990.

OLIVEIRA, J. A. \& TEIXEIRA, S. M. F. Medicina de grupo: a medicina e a fábrica. In: GUIMARÃES, R. (Org.) Saúde e Medicina no Brasil: contribuição para um debate. Rio de Janeiro: Graal, 1984.

OLIVEIRA, J. A. \& TEIXEIRA, S. M. F. (Im)Previdência Social. Petrópolis: Vozes, Abrasco, 1986.

OSLZLAC, O. \& FELDER, R. A capacidade de regulação estatal na Argentina. Revista de Serviço Público, ano 51, 1, 2000.

OSTROM, E. An agenda for the study of institutions. Public Choice, 48(1): 3-25, 1986.

PACI, R. Ma il male sta nelle fasce sociali. In: VIANNA, M. L. T. W. $A$ Americanização (Perversa) da Seguridade Social no Brasil. Rio de Janeiro: Revan, Ucam, Iuperj, 1998.

PAIM, J. S. A universidade e a Reforma Sanitária. Saúde Para Debate, 4: 108, 1991.

PELTZMAN, S. The economic theory of regulation after a decade of deregulation. Brookings Papers on Economic Activity, 1-59, 1989.

PEREIRA, C.; COSTA, N. \& GIOVANELLA, L. O jogo da regulação da saúde suplementar no Brasil. Novos Estudos, 60, 2001.

PEREIRA, C. \& MUELLER, B. Uma teoria da preponderância do Poder Executivo. Revista Brasileira de Ciências Sociais (RBCS), 15(43): 421-452, 2000.

PESQUISA NACIONAL POR AMOSTRA DE DOMICÍLIOS - PNAD/ IBGE, 1998. Microdados.

PIERSON, P. When effect becomes cause: police feedback and political change. World Politics, 45(4): 595-628, 1993.

PIERSON, P. Dismantling the Welfare State? Reagan, Thatcher, and the politics of retrenchment. Cambridge: Cambridge University Press, 1994. 
POLANCO, J. D. Elementos para la construccion de una estrategia frente al proceso de privatización de los servicios de salud en Venezuela. In: EIBENSCHUTZ, C. (Org.) Política de Saúde: o público e o privado. Rio de Janeiro: Editora Fiocruz, 1995.

POSSAS, C. de A. Saúde e Trabalho: a crise da Previdência Social. Rio de Janeiro: Graal, 1981.

POWELL, W. W. \& DiMAGGIO, P. J. The New Institutionalism in Organizational Analysis. Chicago, Londres: University of Chicago Press, 1991.

REIS, F. W. 'Governabilidade’ e instituições políticas. In: VELLOSO, J. P. dos R. (Coord.) Governabilidade, Sistema Político e Violência Urbana. Rio de Janeiro: José Olympio, 1994.

REZENDE DA SILVA, F. \& MAHAR, D. Saúde e Previdência Social: uma análise econômica. Rio de Janeiro: Ipea, Inpes, 1974.

RIKER, W. Implications from the disequilibrium of majority rule for the study of institutions. The American Political Science Review, 74(2): 432-446, 1980.

RODRIGUES NETO, E. A via do parlamento. In: FLEURY, S. (Org.) Saúde e Democracia: a luta do Cebes. São Paulo: Lemos Editorial, 1997.

ROSAS, E. J. A Extensão de Cobertura dos Serviços de Saúde no Brasil: PIASS - análise de uma experiência, 1981. Dissertação de Mestrado, Rio de Janeiro: Escola Nacional de Saúde Pública, Fundação Oswaldo Cruz.

SANTOS, W. G. dos. Cidadania e Justiça. Rio de Janeiro: Campos, 1979.

SHEPSLE, K. Institutional equilibrium and equilibrium institution. In: WEISBERG, H. F. (Ed.) Political Science: the science of politics. New York: American Political Science Association, Agathon Press, 1986.

SENADO FEDERAL. Projeto de Lei ñ 4.425/94, que Dispõe sobre Planos e Seguros Privados de Saúde e dá Outras Providências.

SENADO FEDERAL. SSINF - SUBSECRETARIA DE INFORMAÇÕES. Tramitação da Lei 9.961/2000, que cria a Agência Nacional de Saúde Suplementar.

SINDICATO DOS MÉDICOS DE MINAS GERAIS. Sindimed/MG: 30 anos. Belo Horizonte: Sindimed-MG, 2000.

SINDICATO DOS MÉDICOS DE MINAS GERAIS. Jornal do Sindicato, 82. Belo Horizonte: Sindimed-MG, 2002.

SISTEMA DE INFORMAÇÕES SOBRE ORÇAMENTOS PÚBLICOS EM SAÚDE (SIOPS). Disponível em: <siops.datasus.gov.br>.

SKOCPOL, T. Bringing the state back in: strategies of analysis in current research. In: EVANS, P. B.; RUESCHEMEYER, D. \& SKOCPOL, T. (Ed.) Bringing the State Back In. Cambridge: Cambridge University Press, 1985. 
STIGLER, G. T. The Citizen and the State: essays on regulation. Chicago: The University of Chicago Press, 1975.

STRALEN, C. J. van. A reforma sanitária no Brasil: aonde chegamos? In: SINDICATO DOS MÉDICOS DE MINAS GERAIS. SindemedMG: 30 anos. Belo Horizonte: Sindmed-MG, out. 2000.

SUBIRATS, J. Democracia: participación y eficiencia. Gestión y Análisis de Politicas Publicas (Gapp), 5-6: 35-44, 1996.

SUNSTEIN, C. R. After the Rights Revolution: reconceiving the regulatory state. Cambridge: Harvard University Press, 1990.

TEIXEIRA, S. M. F. O dilema reformista na reforma sanitária brasileira. Revista de Administração Pública, 21(4): 94-115, 1987.

THELEN, K. \& STEINMO, S. Historical institutionalism in comparative politics. In: STEINMO, S.; THELEN, K. \& LONSTRETH, F. (Eds.) Structuring Politics: historical institutionalism in comparative analysis. Cambridge: Cambridge University Press, 1992.

TOWERS PERRIN. Planos de Benefícios no Brasil, 17ª Pesquisa, 1997.

TOWERS PERRIN. Planos de Benefícios no Brasil, 19a Pesquisa, 1999/2000.

TOWERS PERRIN. Planos de Benefícios no Brasil, 20ª Pesquisa, 2001/2002.

TRIBUNAL DE CONTAS DA UNIÃO (TCU). Decisão 143/2002. Sessão Ordinária do Plenário de 6 mar. 2002.

UGÁ, M. A. et al. A regulação da atenção à saúde nos EUA. In: MINISTÉRIO DA SAÚDE. Regulação \& Saúde: estrutura, evolução e perspectivas da assistência médica suplementar/Ministério da Saúde, Agência Nacional de Saúde Suplementar. Rio de Janeiro: ANS, 2002.

UNIMED BRASIL. Disponível em: <www.unimed.com.br>. Acesso em: 28 jun. 2002.

VAITSMAN, J. Corporativismo: notas para sua aplicação no campo da saúde. In: TEIXEIRA, S. F. (Org.) Reforma Sanitária: em busca de uma teoria. São Paulo, Rio de Janeiro: Cortez, Abrasco, 1989.

VIANA, A. L. As políticas sociais e as políticas de saúde. In: GERSCHMAN, S. \& VIANNA, M. L. W. (Orgs.) A Miragem da Pós-Modernidade: democracia e políticas sociais no contexto da globalização. Rio de Janeiro: Editora Fiocruz, 1997.

VIANA, A. L. As políticas de saúde nas décadas de 80 e 90: o (longo) período de reformas. In: CANESQUI, A. M. (Org.) Ciências Sociais e Saúde para o Ensino Médico. São Paulo: Hucitec, Fapesp, 2000. (Saúde em Debate, Série Didática)

VIANNA, M. L. T. W. A Americanização (Perversa) da Seguridade Cocial no Brasil. Rio de Janeiro: Revan, Ucam, Iuperj, 1998. 
VOGEL, S. Freer Markets, More Rules: regulatory reform in advanced industrial countries. Ithaca: Cornell University Press, 1996.

WEIR, M. Ideas and the politics of bounded innovation. In: STEINMO, S.; THELEN, K. \& LONSTRETH, F. (Eds.) Structuring Politics: historical institutionalism in comparative analysis. Cambridge: Cambridge University Press, 1994.

WILLIAMSON, O. The Economic Institutions of Capitalism: firms, markets, relational contracting. New York: The Free Press, 1985.

WILSON, J. Q. Political Organizations. New Jersey: Princeton University Press, 1995.

\section{Pessoas entrevistadas}

Guilherme Ribeiro Câmara, diretor de Interior e vice-diretor de Saúde do Trabalhador do Sindicato dos Médicos de Minas Gerais, membro do Coletivo de Saúde Intersindical da CUT/MG. 18 dez. 2002.

Helvécio Magalhães, assessor especial da Secretaria municipal de Saúde de Belo Horizonte. 18 dez. 2002. Secretário municipal de Saúde desde janeiro de 2003.

João Luís Barroca de Andréa, diretor de Normas e Habilitação dos Produtos/ ANS. Maio de 2001.

José Fernando Rossi, presidente da Abramge-MG. Outubro de 2002.

Leda Lúcia C. de Vasconcelos, diretora adjunta de Normas e Habilitação dos Produtos/ANS. Maio de 2001.

Maria Angélica Mesquita, gerente de Pesquisa da ANS. Maio de 2001.

Rafael Guerra, médico, deputado federal pelo PSDB-MG. 26 maio. 2002.

Ruth de Lourdes da Conceição Costa, diretora de Saúde do Sindicato dos Trabalhadores em Telecomunicações (Sintel) e membro do Coletivo de Saúde Intersindical da CUT-MG. Dezembro de 2002.

Virgílio Baião Carneiro, presidente da Associação de Serviços Assistenciais de Saúde Próprios de Empresas em Minas Gerais (Asaspe-MG). Julho de 2002. 
Formato: $16 \times 23 \mathrm{~cm}$

Tipologia: Garamond

Papel: Pólen Bold $70 \mathrm{~g} / \mathrm{m}^{2}$ (miolo)

Cartão Supremo $250 \mathrm{~g} / \mathrm{m}^{2}$ (capa)

CTP, Impressão e acabamento: Imprinta Express Gráfica e Editora Ltda.

Rio de Janeiro, outubro de 2007.

Não encontrando nossos títulos em livrarias, contactar a EDITORA FIOCRUZ:

Av. Brasil, 4036 - Térreo- sala 112 - Manguinhos

21040-361 - Rio de Janeiro - RJ

Tel.: (21) 3882-9039 e 3882-9041

Telefax: (21) 3882-9006

e-mail: editora@fiocruz.br

http://www.fiocruz.br/editora 

Formato: $16 \times 23 \mathrm{~cm}$

Tipologia: Times New Roman

Bauer Bodoni BT

Papel: Pólen Bold $70 \mathrm{~g} / \mathrm{m}^{2}$ (miolo)

Cartão Supremo $250 \mathrm{~g} / \mathrm{m}^{2}$ (capa)

Reimpressão e acabamento: Imprinta Express Gráfica e Editora Ltda.

Rio de Janeiro, junho de 2011.

Não encontrando nossos títulos em livrarias, contactar a EDITORA FIOCRUZ:

Av. Brasil, 4036 - Térreo- sala 112 - Manguinhos

21040-361 - Rio de Janeiro - RJ

Tel.: (21) 3882-9039 e 3882-9041

Telefax: (21) 3882-9006

e-mail: editora@fiocruz.br

www.fiocruz.br/editora 